UNIVERSIDADE DE SÃO PAULO

FACULDADE DE FILOSOFIA, LETRAS E CIÊNCIAS HUMANAS DEPARTAMENTO DE GEOGRAFIA

PROGRAMA DE PÓS-GRADUAÇÃO EM GEOGRAFIA HUMANA

ALEXANDRE ORTOLANI DE AQUINO

CONTRIBUIÇÕES DA REVISTA BRASILEIRA DE GEOGRAFIA E DO DEPARTAMENTO DE GEOGRAFIA DA USP À CIÊNCIA GEOGRÁFICA, ENTRE 1939 E 1956 


\title{
CONTRIBUIÇÕES DA REVISTA BRASILEIRA DE GEOGRAFIA E DO DEPARTAMENTO DE GEOGRAFIA DA USP À CIÊNCIA GEOGRÁFICA, ENTRE 1939 E 1956
}

\begin{abstract}
Dissertação apresentada ao Programa de PósGraduação em Geografia Humana do Departamento de Geografia da Faculdade de Filosofia, Letras e Ciências Humanas da Universidade de São Paulo, como requisito para obtenção do título de Mestre em Geografia Humana.
\end{abstract}

Área de concentração: História da Geografia Orientador: Prof. Dr. Elvio Rodrigues Martins 
Autorizo a reprodução e divulgação total ou parcial deste trabalho, por qualquer meio convencional ou eletrônico, para fins de estudo e pesquisa, desde que citada a fonte.

Catalogação na Publicação

Serviço de Biblioteca e Documentação

Faculdade de Filosofia, Letras e Ciências Humanas da Universidade de São Paulo

Aquino, Alexandre ortolani de

Contribuições da Revista Brasileira de Geografia e

do Departamento de Geografia da USP à ciência

geográfica, entre 1939 e 1956 / Alexandre Ortolani

de Aquino; orientador Elvio Rodrigues Martins. -

São Paulo, 2016 .

$218 \mathrm{f}$.

Dissertação (Mestrado) - Faculdade de Filosofia, Letras e Ciências Humanas da Universidade de são

Paulo. Departamento de Geografia. Área de

concentração: Geografia Humana.

1. Geografia. 2. História da Geografia. 3.

Instituições de Pesquisa. 4. IBGE. 5. USP. I.

Martins, Elvio Rodrigues, orient. II. Título. 
Nome: AQuino, Alexandre Ortolani de.

Título: Contribuições da Revista Brasileira de Geografia e do Departamento de Geografia da USP à ciência geográfica, entre 1939 e 1956

Dissertação apresentada ao Programa de PósGraduação em Geografia Humana do Departamento de Geografia da Faculdade de Filosofia, Letras e Ciências Humanas da Universidade de São Paulo, como requisito para obtenção do título de Mestre em Geografia Humana.

Aprovado em:

Banca Examinadora

Prof. Dr.

Julgamento:

Prof. Dr.

Julgamento:

Prof. Dr.

Julgamento:
Prof. Dr.

Julgamento:

Prof. Dr.

Julgamento:

Prof. Dr.

Julgamento: 
À minha mãe, ao meu pai (in memoriam), ao meu irmão e ao David. 


\section{AGRADECIMENTOS}

Sem a compreensão, o carinho e o acolhimento de algumas pessoas próximas a mim, cujas existências compensam a necessidade de justificação diária do caminho escolhido, eu jamais teria sobrevivido ao processo.

À minha mãe. Sua sabedoria, generosidade e força colocam constantemente minhas certezas em xeque. Sábio foi aprender a ouvi-la e a respeitá-la. Aproveito a oportunidade para um pedido público de desculpas à pessoa que, por três anos suportou, de maneira desconcertante, uma pessoa mais rude, impaciente e explosiva ao seu lado. "Desculpe-me."

Ao Departamento de Geografia da USP e a dedicação de seus profissionais.

Ao Prof. Elvio Rodrigues Martins, autêntico pensador cujas ideias há dez anos me fascinam e cuja precisão dos conselhos me orientaram ao longo destes três anos de crescente confusão.

À Profa. Dra. Larissa Mies Bombardi e ao Prof. Dr. Jorge Luiz Barcellos da Silva, por aceitarem compor a Banca de Qualificação e oferecerem alguns conselhos efetivamente decisivos para o desenvolvimento das ideias.

Aos profissionais que me acompanham no Colégio Nossa Sra. da Misericórdia, pelo apoio moral. Aos meus alunos, cujo interesse, respeito e admiração por minhas ideias me motivam diariamente a melhorar pessoal e profissionalmente.

Ao amigo Renato, por tantos anos de amizade e por sua grande ajuda na tabulação dos materiais publicados na Revista Brasileira de Geografia, por meio de um macro no Excel.

Aos amigos Rita e Bruno. À Rita, pela inestimável amizade e pelo exemplo de pessoa em tempos de crise moral. Ao Bruno, pelas incontáveis prosas e fumarolas madrugadas a dentro, que semanalmente foram minha salvação.

Aos amigos Alice e Eduardo, pelo acolhimento e amizade sinceras e pela compreensão, sem necessidade de explicações, do que é a vida de um pós-graduando.

Ao amigo Andrés que, apesar do exílio, continua sendo parte da minha vida.

Ao amigo Fernando Diório, pela dedicação lato sensu, pelos conselhos e pelas demonstrações frequentes de preocupação. E também aos amigos Yuri e Juliana, pelos esforços de reaproximação.

Ao amigos Pedro e Gabi e à radiante Júlia, parte rockeira crítica radical da minha família.

E ao meu irmão André, acima de tudo um amigo cujo respeito é fundamental para mim. 
Pra onde vão os trens meu pai?

Para Mahal, Tamí, para Camirí, espaços no mapa, e depois o pai ria: também pra lugar algum meu filho, tu podes ir e ainda que se mova o trem tu não te moves de ti.

Hilda Hilst, excerto de "Axelrod (da proporção)". 
Iniciando as brilhantes palestras programadas para o $X$ Congresso Brasileiro Geografia noutro local desta REVISTA, o Prof. JORGE ZARUR proferiu, no dia 8 de setembro, a conferência aqui transcrita.

Apresentando-o, assim se expressou o Dr. CRISTÓvão LEITE DE CASTRO:

Cabe-me a tarefa de apresentar o conferencista de hoje. Vou apresentá-lo com duas palavras - o geógrafo moderno. Mas, para que seja bem entendido, preciso esclarecer o que entendo por geógrafo e o que entendo por geógrafo moderno.

O QUE ENTENDO POR GEÓGRAFO

Podemos considerar três grupos de atividades geográficas - a medição do território, a representação do território $e$ a interpretaçẫo do território.

\section{A MEDIÇÃO DO TERRITÓRIO}

A medição do território exige a atuaçầo de astrônomos, geodesistas, topógrafos e de aerofotogrametristas ou, se quiserem. de fotogrametristas.

\section{A REPRESENTAÇÁO DO TERRITÓRIO}

A representaçấo do território exige a colaboraça de cartógrafos, cu melhor, de colaboração de cartógrafos
desenhistas cartógrafos.

A INTERPRETAÇÃO DO TERRITÓRIO

Finalmente, na interpretação do território é que atua o que se chamageógrafo.

\section{O QUE ENTENDO POR GEÓGRAFO MODERNO}

Entendo por geógrafo moderno aquêle que faz a interpretação dentro de três caracteristicas fundamentais: primeira, o caráter científico, isto é, a explicaçấo dos fenômenos; segunda, tenha a interpretacão, como fundamental, a consideracão do homem - é a tendência moderna da Geografia: terceira haja na interpretaçâ $u m$ sentido de utilidade.

Apresento-vos JORGE ZARUR, geógrafo moderno.

Depois da palestra que vai fazer, quero merecer de cada um de vós um pronunciamento sôbre se acertei ou não na apresentação.

Quadro de apresentação elaborado pela Redação do IBGE.

Jorge Zarur. Geografia: ciência moderna ao serviço do homem. Revista Brasileira de Geografia, v. 6, n. 3, 1944, p. 313. 


\section{RESUMO}

Aquino, A. O. Contribuições da Revista Brasileira de Geografia e do Departamento de Geografia da USP à ciência geográfica, entre 1939 e 1956. 2016. 219 f. Dissertação (Mestrado) - Departamento de Geografia, Universidade de São Paulo, São Paulo, 2016.

O objetivo geral da pesquisa consiste em analisar a vinculação do Conselho Nacional de Geografia (CNG) e do Departamento de Geografia da Universidade de São Paulo (DG-USP) às demandas do Estado brasileiro e a emergência de um discurso geográfico eminentemente científico, entre o momento de criação dessas instituições, a partir de 1934, e a realização do XVIII Congresso Internacional de Geografia, em 1956, marcos que delimitam um importante período de consolidação do pensamento geográfico brasileiro. Para tanto, além da análise do contexto histórico brasileiro no seio do qual floresceram as principais instituições geográficas modernas, analisa-se a Revista Brasileira de Geografia, principal veículo divulgador da Geografia praticada no Instituto Brasileiro de Geografia e Estatística (IBGE), sediado no Rio de Janeiro, em especial materiais publicados nas subáreas de Cartografia, Geografia Política e Geografia Econômica, selecionados após análise do conjunto do periódico. Representativas do pensamento desenvolvido em São Paulo, analisam-se também seis das primeiras oito teses defendidas junto ao DG-USP e, por fim, estabelece-se uma comparação quanto à natureza do saber produzido entre os centros paulista e carioca de pesquisa em Geografia, a relação estabelecida entre eles e os elementos políticos aos quais se vinculou o pensamento geográfico em diferentes ambientes de produção de conhecimento. Para o desenvolvimento desta pesquisa, parte-se da premissa, consolidada na história do pensamento geográfico, de que o desenvolvimento da ciência geográfica não é eventual ou fortuito, mas está atrelado à consolidação do Estado em sua fase territorial, quando os limites nacionais tendem a se confundir com limites territoriais específicos. O CNG representaria a lógica estatal sobre o território nacional e a este se associaria diretamente o projeto político-cultural das recémcriadas instituições de ensino superior - a Universidade do Distrito Federal e, pouco depois, a Universidade do Brasil. Já o DG-USP se vincularia a um "projeto nacional" diverso, ligado a interesses regionais da elite econômica paulista e, por isso mesmo, manter-se-ia relativamente desassociado dos interesses políticos do Governo Federal. Da ambiguidade entre o pragmatismo da prática e o academicismo na apresentação dos resultados, o serviço tomado para si pela comunidade geográfica justificou a utilidade do saber praticado e criou condições concretas para sua reprodução. $\mathrm{O}$ contexto de reprodução do conhecimento geográfico indica que a relevância institucional e social deste saber advinha da possibilidade de contribuir com o avanço das forças produtivas em território nacional, não apenas junto ao IBGE, mas também junto às Universidades, o que justifica o engajamento político dos geógrafos junto ao Estado. Desta contribuição complacente com o Estado, a Geografia atrelou seu destino às demandas dos grandes círculos de poder e ocasionou uma dissonância entre pensamento e leitura geográfica de mundo, quando a descrição sintética da paisagem deixou de ser suficiente para as necessidades de intervenção sobre a realidade. A pesquisa, assim, além de resgatar fundamentos da forma e do conteúdo que dão sentido à maneira geográfica de ler o mundo, recupera elementos básicos do pensamento geográfico tradicional necessários para a adequada compreensão da crítica subsequente a ele direcionado.

Palavras-chave: História da Geografia, Instituições de pesquisa, CNG, IBGE, USP. 


\begin{abstract}
AQuino, A. O. Contributions of Revista Brasileira de Geografia and Department of Geography of USP to geographical science, between 1939 and 1956. 2016. 219 f. Dissertação (Mestrado) - Departamento de Geografia, Universidade de São Paulo, São Paulo, 2016.

The main objective of this research is to analyze the linkage of the National Council of Geography (Conselho Nacional de Geografia - CNG) and the Department of Geography of the University of São Paulo (DG-USP) to the demands of the Brazilian state and the rise of a essentially geographical scientific discourse between the moment of creation of these institutions, since 1934, and the realization of the XVIII International Congress of Geography, in 1956, an important event that defines a period of consolidation of Brazilian geographical thought. Therefore, besides the Brazilian historical context analysis in midst of which flourished the major modern geographical institutions, it is analyzed the Brazilian Journal of Geography (Revista Brasileira de Geografia), the main promoter vehicle of Geography practiced in Brazilian Institute of Geography and Statistics (Instituto Brasileiro de Geografia e Estatística - IBGE), based in Rio de Janeiro, in particular the material published in Cartography, Political Geography and Economic Geography, subareas selected after analysis of the journal. As representatives of the geographic thought developed in São Paulo, six of the first eight doctoral thesis defended at DG-USP are also analyzed. Finally, it is realized a comparison between the geographical knowledge produced in São Paulo and in Rio de Janeiro research centers, the relationship established between them and the political elements to which the geographical thought in different knowledge production environments were linked. For the development of this research, it is assumed, based on the history of geographical thought, that development of geographical science is not contingent or fortuitous, but is related to the consolidation of the state in its territorial stage, when national limits tend to overlap specific territorial limits. CNG would represent the state logic over the national territory and to it would be directly associated the political-cultural project of the newly established higher education institutions - University of the Federal District and, shortly after, University of Brazil. However, DG-USP would be linked to a different "national project", associated to the local economic elite of São Paulo and, for this very reason, would keep itself relatively disassociated of political interests of Federal Government. From the ambiguity between pragmatism of practice and academicism in the presentation of results, the task assumed by the geographic community justified the utility of the knowledge then practiced and created concrete conditions for their reproduction. The reproduction context of geographical knowledge indicates that institutional and social relevance of knowledge stemmed from the possibility of contributing with the advance of productive forces in national territory not only at IBGE, but also at universities, which explains the political engagement of geographers within the state. From this complacent contribution to the state, Geography linked their fate to the demands of large circles of power and caused a dissonance between thought and geographical reading of the world, since a concise description of the landscape was no longer sufficient for the needs of intervention on reality. Therefore, this research, in addition to rescue foundations of form and content that give meaning to the geographical way of reading the world, recovers basic elements of traditional geographical thought which are necessary for the proper understanding of the subsequent criticism to it directed.
\end{abstract}

Keywords: History of Geography, Research institutions, CNG, IBGE, USP. 


\section{LISTA DE ABREVIATURAS}

\begin{tabular}{ll} 
ABC & Academia Brasileira de Ciências \\
AGB & Associação dos Geógrafos Brasileiros \\
CBG & Conselho Brasileiro de Geografia \\
CNE & Conselho Nacional de Estatística \\
CNG & Conselho Nacional de Geografia \\
CSE & Conselho Superior de Estatística \\
DEC & Diretoria de Estatística Comercial \\
DEPr & Diretoria de Estatística da Produção \\
DEPu & Diretoria de Estatística e Publicidade \\
DG & Departamento de Geografia \\
DGE & Diretoria Geral de Estatística \\
DNE & Departamento Nacional de Estatística \\
DSE & Diretoria do Serviço de Estatística \\
FFCL & Faculdade de Filosofia, Ciências e Letras \\
FNF & Faculdade Nacional de Filosofia \\
IBGE & Instituto Brasileiro de Geografia e Estatística \\
IHGB & Instituto Histórico e Geográfico Brasileiro \\
INE & Instituto Nacional de Estatística \\
INEC & Instituto Nacional de Estatística e Cartografia \\
IPANGH & Instituto Pan-Americano de Geografia e História \\
MA & Ministério da Agricultura \\
MAIC & Ministério da Agricultura, Indústria e Comércio \\
MTIC & Ministério do Trabalho, Indústria e Comércio \\
MF & Ministério da Fazenda \\
RBG & Revista Brasileira de Geografia \\
SCG & Serviço de Coordenação Geográfica \\
SCGF & Serviço de Geografia e Estatística Fisiográfica \\
SET & Secretaria de Estatística Territorial \\
SGRJ & Sociedade de Geografia do Rio de Janeiro \\
UDF & Faculdade do Distrito Federal \\
UGI & União Geográfica Internacional \\
& Universidade de São Paulo \\
\hline USP &
\end{tabular}




\section{SUMÁRIO}

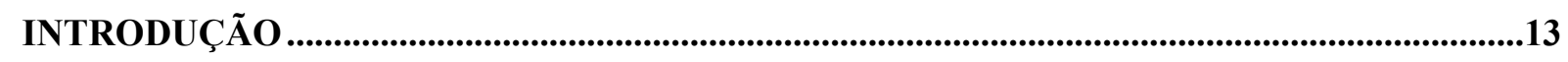

1. A FORMAÇÃO DO INSTITUTO NACIONAL DE ESTATÍSTICA.........................................18

1.1. O TERRITÓRIO NACIONAL - OBJETO DE ESTUDO E ESCALA DE ATUAÇÃO............22

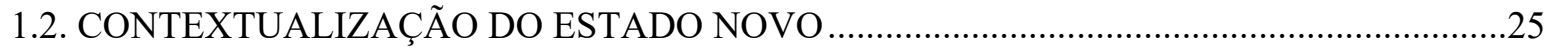

1.3. A GEOGRAFIA JUNTO ÀS PRÁTICAS DO PLANEJAMENTO..........................................28

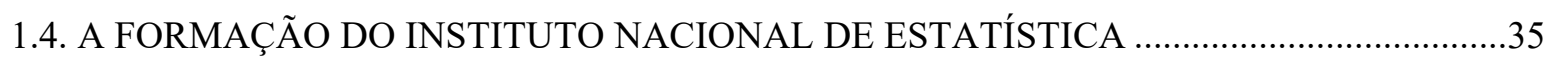

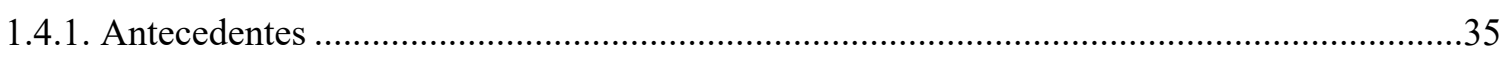

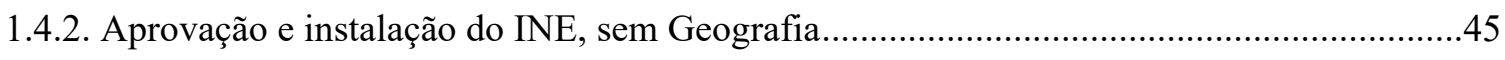

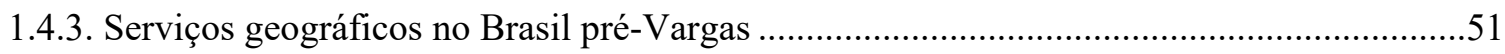

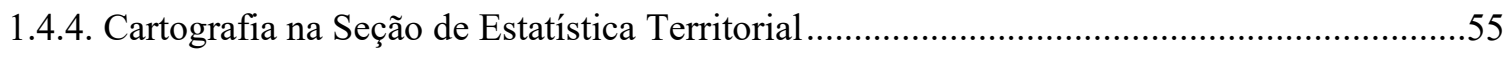

2. CONTRIBUIÇÕES DO CNG A PARTIR DA REVISTA BRASILEIRA DE GEOGRAFIA....61

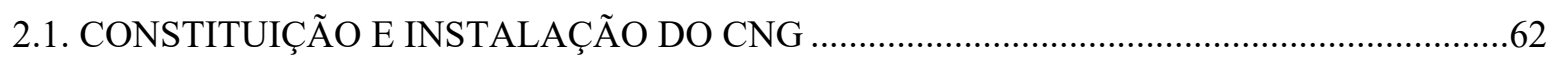

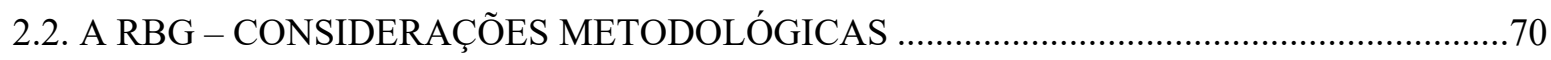

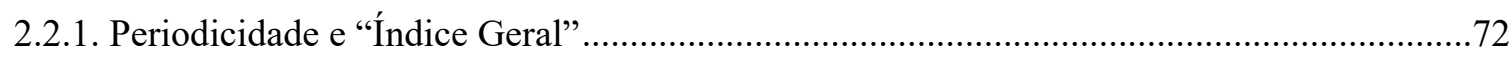

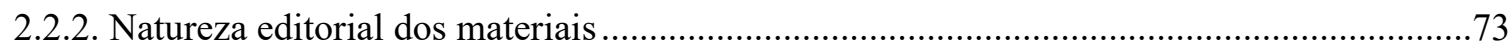

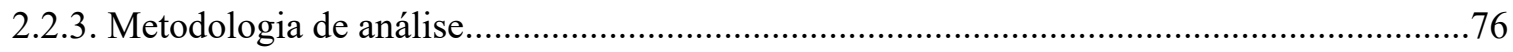

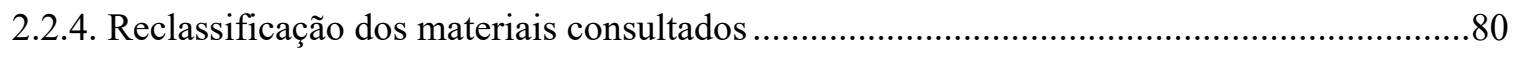

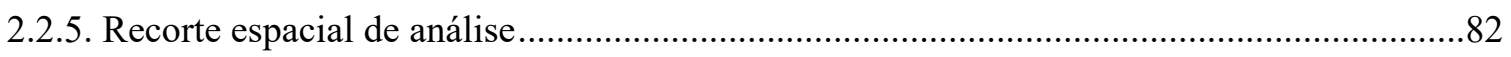

2.3. ANÁLISE QUANTO AO TEMA DOS MATERIAIS CONSIDERADOS ...............................84

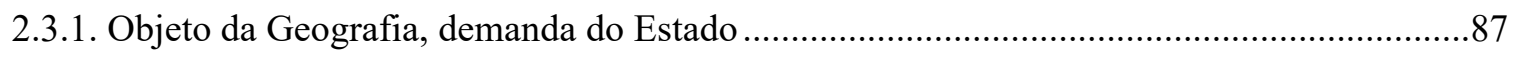

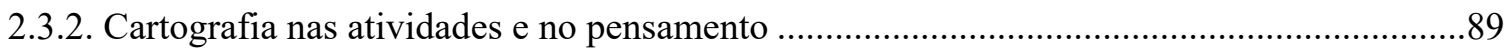

2.3.2.1. As contribuições de Francis Ruellan .................................................................................94

2.3.2.2. Da Cartografia à Política - outra faceta geográfica.........................................................98

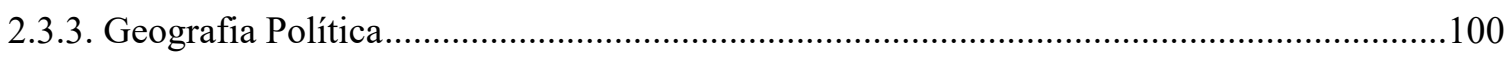

2.4. A PERSPECTIVA TÓPICA DA GEOGRAFIA ECONÔMICA …........................................110

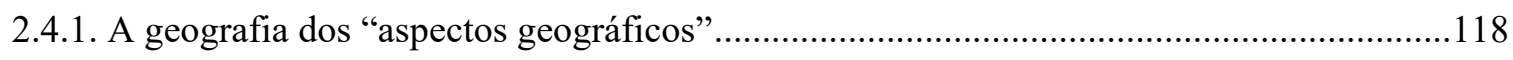

3. A PARTICIPAÇÃO DO DG-USP FRENTE À AÇÃO CENTRALIZADORA DO ESTADO.122

3.1. “CREA A UNIVERSIDADE DE SÃO PAULO E DÁ OUTRAS PROVIDÊNCIAS”...........124

3.1.2. Institui-se Faculdade de Filosofia - e a Geografia - no Brasil.............................................127

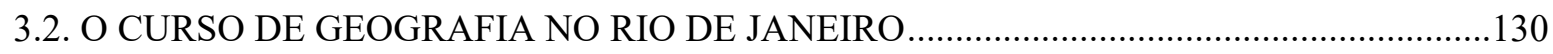

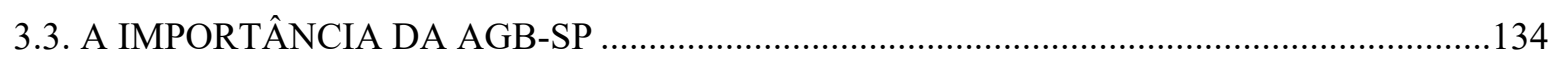

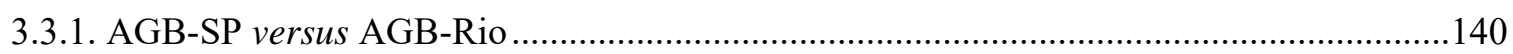




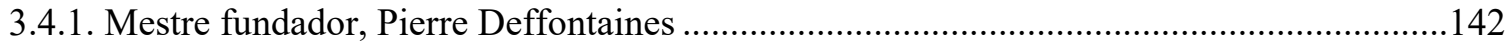

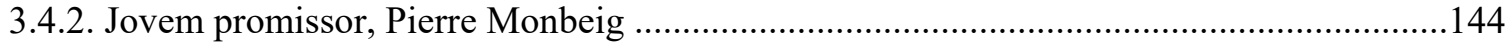

3.5. DIMENSÃO POLÍTICA DO SABER GEOGRÁFICO ….....................................................150

3.5.1. Efetiva apropriação do saber geográfico pelo Estado ...........................................................153

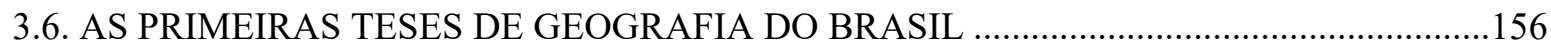

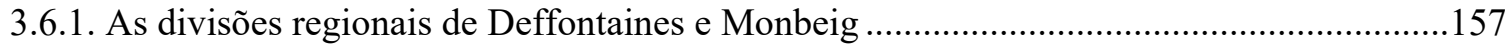

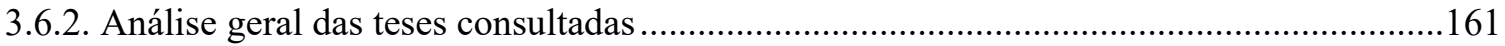

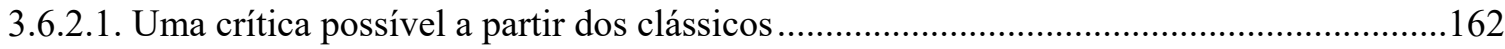

3.6.2.2. Eleição da região-objeto e determinismo geográfico ........................................................165

3.6.2.3. A explicitação de um modelo, segundo Silveira (1948)...................................................170

3.6.3. O pioneirismo de Carvalho (1944) e a posição estratégica de Santos..................................173

3.6.4. Civilização no meio tropical e progresso, em Araújo Filho (1950) …………......................178

3.6.5. Padrões de paisagem caipira, segundo Müller (1951).......................................................181

3.6.6. Cartografia da evolução da paisagem, segundo Mendes (1948) .........................................184

3.6.7. Santos (1951) e a justificação antropocêntrica de seu estudo ..............................................189

3.7. GEOGRAFIA À SERVIÇO DO GRANDE EMPREENDIMENTO ........................................193

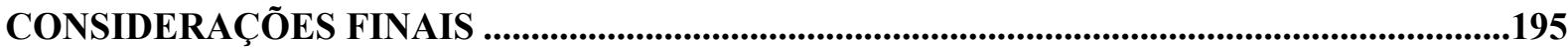

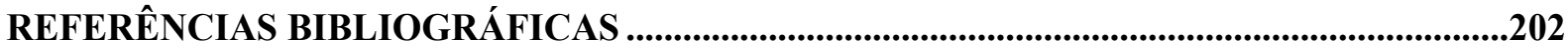

ANEXOS 


\title{
INTRODUÇÃO
}

O objetivo geral do presente trabalho consiste em analisar a vinculação do Conselho Nacional de Geografia e do Departamento de Geografia da Universidade de São Paulo às demandas do Estado brasileiro e a emergência de um discurso geográfico eminentemente científico, entre 1937 e 1956. A questão central que se visa aprofundar é a compreensão da dupla natureza científica e política do saber geográfico praticado por dois dos principais centros de produção acadêmica em Geografia, à época.

A rigor, a pesquisa retrocede até o ano de fundação da Universidade de São Paulo, em 1934, quando surge a subseção de Geografia e História da então Faculdade de Filosofia, Ciências e Letras, mas oferece maior detalhamento histórico a partir da fundação do Conselho Nacional de Geografia (CNG), em 1937. A realização do XVIII Congresso Internacional de Geografia foi escolhido como segundo marco temporal para delimitar esta pesquisa, já que se tratou do "maior congresso de Geografia de todos os tempos. O primeiro na região tropical, na faixa tropical e, também, o primeiro no hemisfério sul.” (VALVERDE, 1998, apud ABRANTES, 2014, p. 5)

\begin{abstract}
O período entre o início dos anos 1940 e final dos anos 1950 é chamado pelos geógrafos do IBGE de época de ouro da pesquisa de campo, o qual teria culminado com as expedições geográficas efetuadas em 1956 no XVIII Congresso Internacional de Geografia e, em 1957, com as pesquisas de campo que visavam à elaboração da Enciclopédia dos Municípios Brasileiros. (ABRANTES, 2014, p. 5)
\end{abstract}

Em função, ainda, dos esforços empreendidos na realização do referido Congresso,

o CNG lançou um conjunto de obras, que talvez tenha sido o maior e mais completo conjunto de trabalhos geográficos sobre o Brasil em um curto espaço de tempo: a Enciclopédia dos Municípios Brasileiros, as coleções Grandes Regiões, Atlas do Brasil e a Carta do Brasil ao Milionésimo. (AlmEIDA, 2000, p. 53) ${ }^{1}$

Mais do que um destacado volume de obras de referência, que marcam um ciclo de consolidação do pensamento geográfico no Brasil, a realização do Congresso delimita o início do fim de uma era. (Monteiro, 1980; Nogueira, 2015) A partir de então, intensificando-se sobremaneira a partir meados da década seguinte, a Geografia praticada pelo IBGE experimentará mudanças em sua metodologia, até então fortemente ancorada na prática indutivista da observação direta através dos trabalhos de campo, com a adoção do universo estatístico da Geografia Quantitativa. Além disso, temas ligados às questões agrícolas, até

\footnotetext{
${ }^{1}$ Cf. também IBGE. XVIII Congresso Internacional de Geografia. Boletim Geográfico, v. 13, n. 128, 1955, p. 580-581. (Noticiário.)
} 
então majoritários nas publicações da Revista Brasileira de Geografia, cedem lugar para materiais voltados à questão urbana. ${ }^{2}$

A escolha pela análise dos materiais publicados nos dois referidos centros de estudo justifica-se, além da precedência na institucionalização de ambos, em virtude da rica possibilidade de comparação da natureza do saber produzido em cada um dos polos difusores de conhecimento. O Conselho Nacional de Geografia, vinculado ao Instituto Brasileiro de Geografia e Estatística (IBGE), representava a lógica estatal sobre o território nacional, e a este associava-se diretamente o projeto político-cultural das recém-criadas instituições de ensino superior - a Universidade do Distrito Federal, de iniciativa municipal e, pouco depois, a Universidade do Brasil, cuja criação levaria a primeira à extinção. A condição histórica de capitalidade do Rio de Janeiro, apesar da vantagem quanto ao financiamento para a realização de pesquisas, dificultou qualquer desvinculação com o Estado e a "construção intelectual de visões politicamente independentes do governo federal." (MACHADO, 2009, p. 107) Já o Departamento de Geografia da Universidade de São Paulo (DG-USP) vinculava-se a um "projeto nacional" diverso (SEABRA, 2004), ligado aos interesses regionais da elite econômica paulista e, por isso mesmo, manteve-se relativamente desassociado dos interesses políticos do Governo Federal. Isto posto, pode-se investigar os elementos de proximidade e distanciamento entre os centros paulista e carioca de pesquisa em Geografia, a relação estabelecida entre eles e os elementos a que se vincula o pensamento geográfico em diferentes ambientes de produção de conhecimento.

Para o desenvolvimento desta pesquisa, parte-se da premissa, consolidada na história do pensamento geográfico, de que o desenvolvimento da ciência geográfica não é eventual ou fortuito, mas está atrelado à consolidação do Estado em sua fase territorial, quando os limites nacionais tendem a se confundir com limites territoriais específicos. (CAPEL, 1981)

No Brasil, a instalação de serviços geográficos oficiais e de instituições de ensino superior alinhadas aos parâmetros internacionais e o correlato desenvolvimento de discursos geográficos de legitimação estatal se processam com maior vigor no contexto do Estado Novo, período em que a formulação de políticas territoriais subsidiaria a modernização do território e sua maior inserção nos fluxos internacionais de capital, de lógica urbano-industrial.

Da associação entre a nascente ciência geográfica moderna brasileira e a primeira experiência política de abrangência efetivamente nacional no Brasil emergiria um campo profissional e um ambiente privilegiado para a reflexão geográfica. O saber produzido por

\footnotetext{
${ }^{2}$ Dos 94 materiais publicados na Revista Brasileira listados na subárea da Geografia Urbana, entre 1939 e 1983, apenas 11 foram publicados até 1956.
} 
essa Geografia carrega uma importante componente política, mais explícita junto ao pensamento que emergia dos serviços prestados pelo CNG, porém evidente também na produção acadêmica do curso de Geografia e História da Universidade de São Paulo.

Lacoste (2012 [1976], p. 127) afirma ser incapaz de encontrar "qualquer justificativa teórica para a exclusão, do campo da geograficidade ${ }^{3}$, da categoria de fenômenos políticos que são cartografáveis [...] e cuja importância social é, quer se queira, quer não, também indiscutível." A exclusão do político teria tido como efeito

distanciar os geógrafos universitários de toda idéia de ação e privá-los dessa geografia fundamental ${ }^{4}$ que é, no que possui de essencial, uma geografia ativa ao pé da letra e que continuou a se desenvolver, aí compreendendo a cartografia, fora das estruturas universitárias, nos organismos que dependem diretamente do aparelho de Estado. (LACOSTE, 2012, p. 127)

De fato, a constituição do CNG foi da maior importância para a possibilidade de descrição, conhecimento e efetivação do domínio do território pelo Estado, e atrelado a isso, para o desenvolvimento do pensamento geográfico brasileiro. Diferentemente da experiência histórica europeia, contudo, não haviam centros universitários já consolidados no Brasil para perderem a possibilidade de desenvolvimento de uma "geografia fundamental" para, no caso, o CNG. No Brasil, este Conselho desde seu início assume um centralismo na produção de conteúdo, conforme podemos atestar em Seabra:

a AGB, como 'subproduto' da criação da USP, carregaria em si, (in)dependente da vontade de seus membros, esta possibilidade de colocar os conhecimentos que produz, e aos que pretende dar organicidade, também a serviço da expansão econômica do Estado de São Paulo. (SEABRA, 2004, p. 34)

Porém, se este era o projeto, o conhecimento produzido na Associação dos Geógrafos Brasileiros - AGB não tinha à época abrangência para realizá-lo. Esta possibilidade sofre o impacto da ação centralizadora do Estado Novo e da fundação do IBGE. Segundo Seabra,

nem toda a vontade de que estavam imbuídos os fundadores da AGB e seus primeiros sócios poderia competir com tal estruturação centralizada de produção, coleta e organização da informação estatística e geográfica do país que o governo federal estava promovendo. (SEABRA, 2004, p. 35)

Assim, da tensão entre o discurso dos geógrafos da época e da participação das entidades geográficas junto ao Estado, o CNG assumiria o duplo papel, ainda pouco explorado historicamente, de possibilitar maior avanço teórico da disciplina, bem como maior

\footnotetext{
${ }^{3}$ Lacoste (2012) entende por geograficidade aqueles temas que podem ser classificados como geográficos, portanto, do âmbito de estudo do geógrafo, ou seja, segundo seu entendimento, todos aqueles fenômenos "cartografáveis".

${ }^{4}$ Por "geografia fundamental" Lacoste compreende uma ciência muito anterior à instituição universitária e essencialmente ligada à cartografia e aos "fenômenos que advêm do político, sobretudo aqueles que estão ligados ao exercício dos poderes de Estado". (LACOSTE, 2012, p. 125)
} 
penetração do capital e do próprio poder estatal no território nacional. A participação do Departamento de Geografia da USP neste contexto carece, igualmente, ser melhor esclarecido.

Para tanto, parte-se da leitura das teses de doutorado defendidas junto ao DG-USP e dos artigos da Revista Brasileira de Geografia (RBG) já que, até “os anos 70, o IBGE foi o principal centro de adoção e difusão de todas as novas ideias e métodos surgidos na Geografia mundial" (GEIGER, 1988, p. 66) e a RBG, seu principal veículo divulgador. Realiza-se um estudo comparativo entre os materiais, dentro do período considerado, tomando por base o recorte temático, os objetivos possíveis de serem inferidos e os conceitos-chave empregados.

O desenvolvimento da pesquisa, alguns autores foram decisivos para a interpretação dos materiais considerados, ainda que tenham sido breves em suas tão inspiradoras afirmações. Referimo-nos, especialmente, a Lacoste (2012 [1976]), Seabra (2004) e Backheuser (1942). Em termos de fundamentação geral e de compreensão da natureza do saber geográfico, Santos (2004), Martins (2009) e Ribeiro (2015), além do excelente trabalho de Penha (1993) nos influenciaram sobremaneira e deram solidez a interpretações do âmbito específico da pesquisa.

A pesquisa, em seu conjunto, revelou algumas limitações importantes. O texto apresentase acentuadamente descritivo, carente de um nexo discursivo explícito. Em parte, isto se deve às incertezas iniciais quanto ao objeto proposto, que se mostrou, afinal, excessivamente amplo e carente de pesquisas prévias já existentes. Além disso, a análise dos materiais consultados teria se enriquecido caso tivéssemos nos aprofundado no debate epistemológico que dá conta das diferentes formas por meio das quais os geógrafos encaram intelectualmente seu objeto de estudo. A necessidade de tal entendimento intensificou-se já na fase final da pesquisa, quando os elementos analisados entrecruzaram-se e ganharam maior sentido.

Justificada à princípio pelo interesse sobre a natureza do saber geográfico, a possibilidade de um pensamento geográfico sobre o mundo e sua efetiva potencialidade crítica sobre a realidade, esta pesquisa parece responder a uma pergunta improvável à geração contemporânea à crise do pensamento geográfico tradicional. A ascendência do debate em torno da necessidade de maior relevância social e política para a ciência geográfica, além de marcada pela crítica à vinculação complacente da Geografia junto ao Estado, parte da premissa quanto à clareza do pensamento de sotaque francês que se queria criticar funcionalista, aplicado, fortemente ancorado a práticas indutivistas e pouco atento ao aprofundamento das contradições e conflitos presentes tanto no campo, quanto na cidade. A crítica floresceu em importantes centros de reflexão geográfica, alguns fortemente tributários do modus operandi tradicional, como o Departamento de Geografia da USP, mas, com efeito, 
a premissa para a construção da crítica não parece ter acompanhado o passar do tempo. Não se pode ter constrangimento em se afirmar que, de fato, os geógrafos formados no Departamento de Geografia da USP ao longo dos anos 2000 não tinham clareza do pensamento geográfico tradicional, objeto de crítica da chamada Geografia crítica.

Assim, a presente pesquisa pode parecer um esforço de defesa do pensamento geográfico praticado pelos pioneiros da Geografia moderna no Brasil. O plano de fundo para a justificação de nosso esforço de pesquisa amparava-se na compreensão de um saber disciplinarizado sobre o mundo que parece carecer de uma forma de pensamento clara em seu desenvolvimento contemporâneo. Porém, um subproduto que, talvez, justifique de maneira mais clara nossa pesquisa, repousa na compreensão do próprio objeto de crítica da Geografia crítica.

Isto posto, o texto a seguir está estruturado em três capítulos. No primeiro capítulo, descreve-se o histórico de formação do Instituto Brasileiro de Geografia e Estatística - IBGE, e busca-se contextualizá-lo no âmbito do Estado Novo.

O segundo capítulo, além de descrever a formação do Conselho Nacional de Geografia no interior do IBGE, descreve a estrutura do principal veículo de divulgação da produção intelectual do Conselho, a Revista Brasileira de Geografia. Faz-se, então, uma análise de materiais selecionados em meio a um universo de quase mil materiais publicados ao longo de mais de quatro décadas e busca-se mostrar a forte unidade entre os temas mais populares, bem como o forte engajamento político da ciência geográfica junto ao Estado. Deste compromisso, apesar da postura complacente dos geógrafos frente aos projetos modernização do território levados a cabo pelo Estado brasileiro, emerge-se um sólido campo de atuação que deu ao geógrafo não apenas emprego, mas o ambiente necessário para a consolidação de uma maneira de captar a dimensão geográfica da realidade.

No terceiro capitulo, faz-se semelhante análise aplicada às teses de doutorado defendidas junto ao Departamento de Geografia da USP. Busca-se traçar um paralelo, quanto à finalidade do labor geográfico, com os materiais publicados pela RBG e traça-se alguns questionamentos em termos de engajamento político da disciplina, de estruturação epistemológica do pensamento geográfico e de justificação de uma forma de saber a partir do momento em que este se vê alijado de seu engajamento junto ao Estado. 


\title{
CAPÍTULO 1 \\ A FORMAÇÃO DO INSTITUTO NACIONAL DE ESTATÍSTICA
}

\author{
"Espaço, dimensão material, constituinte das relações sociais e, \\ por isso mesmo, sendo, em si, um poder." (BECKER, 1988, p. 100)
}

Quando se fala em agrupações humanas agrícolas tradicionais, limitadas por tecnologias de produção e comunicação pré-industriais, a extensão territorial própria ao grupo se confunde com os próprios limites da objetividade resultante da apropriação da natureza por essas agrupações. Os grupos humanos estão confinados aos territórios que correspondem ao próprio meio geográfico imediato. Nesse sentido, territórios e gêneros de vida se confundem. (MOREIRA, 2008)

Esta parece ser uma das grandes contribuições teóricas do conceito de "gênero de vida" de Paul Vidal de La Blache à Geografia. De fato, Lencioni (2009) fala em incorporação pelo mestre francês à Geografia do conceito que, ao longo da segunda metade do século XIX, teria sido empregado de forma corrente "no estudo da evolução da humanidade por todos aqueles que se interessavam pelas sociedades primitivas.” (LENCIONI, 2009, p. 103)

O domínio sobre a natureza ao nível da sedentarização gestou distintos gêneros de vida, diferenciados segundo as diferenças próprias a cada meio natural, a variedade de atividades praticada pelos diferentes grupos e, crescentemente, segundo suas práticas culturais, oriundas das próprias relações de produção dos grupos com os diferentes meios. A partir de intercâmbios dos homens entre si e com o meio, por intermédio das técnicas, os gêneros e modos de vida intervieram em seus diferentes meios geográficos e se tornaram um novo princípio de diferenciação na superfície terrestre, além do natural-climático. Há uma íntima correlação de forças entre meios geográficos e diferentes grupos humanos produzindo meios geográficos cada vez mais específicos e originais. Trata-se, portanto, de uma análise em termos históricos de longa duração, cuja leitura da paisagem é o ponto de partida de um esforço intelectual que, por isso mesmo, encontra na descrição um recurso de método importante. (ClaVAL, 1974; MOREIRA, 2008)

\footnotetext{
${ }^{5}$ Bertha Becker fala em "espaço". Evitaremos o uso da categoria tendo em vista sua polissemia e seu amplo espectro de usos, mesmo dentro da ciência geográfica. Observe-se que dentro do recorte temporal considerado na presente dissertação, raros são os geógrafos que utilizam a categoria. Além disso, também optamos por utilizar a grafia "Geografia" para referências à ciência geográfica e "geografia", para referências à dimensão da realidade.
} 
Nesse sentido, a análise geográfica dos gêneros de vida se distingue em termos escalares e em termos de intensidade e alcance de relações que um dado arranjo espacial estabelece com seu entorno. Na Geografia tradicional, a relação sociedade-meio geográfico com a qual se lida é do âmbito de agrupamentos humanos tradicionais eminentemente agrícolas, onde o elemento técnico é minoritário frente à decisiva relação que se estabelece diretamente com a natureza e cujo alcance escalar é reduzido às possibilidades ofertadas pelos instrumentos de trabalho que se confundem, no mais das vezes, a extensões do próprio corpo. Pouco se fala, neste contexto teórico ligado às geografias regionais do mundo rural, das feições geográficas que se generalizam a partir da Revolução Industrial, cuja natureza dos arranjos espaciais chega a não ter nenhuma relação com o entorno direto, mas com determinações totalmente estranhas à escala local.

A compreensão dos gêneros de vida enquanto realidade social - dentro da qual a inércia social traduzida nos costumes desempenha papel primordial -, bem como o estudo do homem por meio de suas obras (CLAVAL, 1974, p. 71-72) - expressas em sólidas paisagens carregadas de história - são fatos já consolidados dentro do pensamento geográfico. As geografias das sociedades tradicionais expressariam, enfim, permanências, cujo ritmo de transformação torna possível o estabelecimento de um conjunto de princípios e conceitos que dão à nascente ciência geográfica, além de um primeiro estatuto epistemológico, os ares de neutralidade científica oriundos das ciências da natureza.

Fato menos consensual em termos teóricos - também porque juízos de valor tornam-se mais facilmente perceptíveis - é o papel político da dimensão geográfica da realidade, especialmente quando se toma em consideração a relação do Estado moderno com o território. A compreensão do papel passivo da materialidade apropriada na condução dos assuntos políticos se torna difusa, porque por vezes - fato especialmente válido no Brasil - a materialidade posta em questão é de fato desconhecida mesmo pelos próprios agentes estatais. No plano do pensamento, trata-se, mesmo, de um caminho possível para o tratamento historiográfico da ciência geográfica brasileira.

A análise se dá em outra escala. Não se trata mais da compreensão dos tipos humanos resultantes de uma íntima e perdurada relação com seu meio geográfico, mas da relação do Estado com seu território, sem perder de vista que esse território não constitui um vazio demográfico.

Lacoste (2012 [1976], p. 25-26), insistirá na "utilidade prática da análise do espaço, sobretudo para a condução da guerra, como ainda para a organização do Estado e prática do poder". Seu livro insiste na promoção do que ele chama de "geografia fundamental", um 
conhecimento indispensável à prática do poder e que, por isso mesmo, surgiu, muito antes da geografia "neutra" universitária, praticante de um "saber pelo saber", a mesma centrada em torno do conceito de gênero de vida. "A geografia existe desde que existem os aparelhos de Estado". Diferentes "análises geográficas, estreitamente ligadas a práticas militares, políticas, financeiras, formam aquilo que se pode chamar 'a geografia dos estados-maiores', desde os das forças armadas até os dos grandes aparelhos capitalistas." Mas a recusa do geógrafo universitário em enfrentar a natureza estratégica do saber com o qual trabalha mantem essa Geografia dos estados-maiores "quase completamente ignorada por todos aqueles que não a executam, pois suas informações permanecem confidenciais ou secretas.” (LACOSTE, 2012, p. 26)

Segundo Becker, Friedrich Ratzel teria sido "um dos poucos geógrafos a assumir explicitamente o valor estratégico do espaço da Geografia" e representou, sem dúvida, um avanço na teorização geográfica do Estado. (BECKER, 1988, p. 100) A reação extrema à postura de naturalização do Estado e do espaço pelo determinismo geográfico, bem como as deformações da Geopolítica nazista, além de desconsiderarem a riqueza teórica da obra ratzeliana, afastaram os geógrafos de todo um conjunto de técnicas e de um saber que instrumentalizam e pensam o espaço a partir da ótica dos Estados-maiores, tornando a Geografia vazia de conteúdo. ${ }^{6}$

No Brasil, a Geografia aproximou-se formalmente do Estado com a criação do Instituto Brasileiro de Geografia e Estatística (IBGE) e das primeiras universidades em São Paulo e Rio de Janeiro, no momento em que o Estado finalmente formula, ainda que de maneira vaga ou atrelada a interesses internacionais, o que se costuma chamar de "objetivos nacionais". A Geografia não foi chamada a contribuir até que a ideia de planejamento, com sua componente territorial, viesse à tona no contexto histórico e político brasileiro.

Lamego (2014) ressalta, nesse sentido,

a existência de uma articulação entre a história do IBGE e a história política
brasileira. [...] É Eomente recorrendo ao desenrolar dos episódios que misturam
diversas camadas contextuais - política nacional e política ibgeana - que é possível
perceber a natureza da geografia desenvolvida no IBGE e sua vinculação aos
componentes das políticas do Estado [...]. (LAMEGO, 2014, p. 3)

Nesse sentido, a Revista Brasileira de Geografia, como se verá no Capítulo 2, disponibiliza diversos exemplos de trabalhos cujo temário reflete não apenas trabalhos de perspectiva considerada clássica ou tradicional, mas um retrato da própria nação cuja

\footnotetext{
${ }^{6}$ Nelson Werneck Sodré (1992 [1976]) faz uma das mais enérgicas críticas à atuação de Ratzel, cuja obra teria avançado sobre uma área estranha à Geografia. Muito amparada na leitura de Lucien Febvre, sua retórica parece desconsiderar o contexto histórico de surgimento de formulações deterministas, sua adoção, inclusive pela Geografia francesa e não apenas por ideólogos do imperialismo, além de desconsiderar em bloco obras inteiras do âmbito da Geografia Política e da Geopolítica.
} 
formação indica a baixa presença do Estado em termos escalares. Esses mesmos trabalhos teriam a finalidade de municiar o Estado para ações concretas sobre o território.

Segundo Costa (2013 [1988]), a formação e estrutura do território nacional tiveram, por vezes, participação muito reduzida das políticas de Estado. No entanto, a partir de 1930, “o Estado reformula-se para enfrentar o que considerava constituir-se como parte da questão nacional brasileira." Alguns "projetos nacionais" concretizaram-se: a construção da "unidade nacional" e da "integração nacional” em torno do próprio Estado; a modernização centralizadora do país e do próprio Estado, independente das diferenças entre os governos; e “a ocupação do território a partir de 'empreendedores' individuais e empresariais, mas segundo mecanismos no mais das vezes institucionais”. (COSTA, 2013 [1988], p. 73) A então chamada Geografia moderna, de alguma forma, se engajará, em favor do Estado, no movimento de transformação de paisagens regionais em segmentos da divisão internacional do trabalho.

Becker (1988) propõe uma geopolítica debruçada sobre as relações entre espaço e poder, já que o poder é multidimensional e emana de múltiplas fontes combinadas, fruto do vetor científico tecnológico moderno. Segundo a autora, o espaço é a dimensão material, constituinte das relações sociais e por isso, em si, um poder. ${ }^{7}$ Moraes (2005) argumenta que a paisagem humana é o resultado de uma dialética entre matéria e ideia. Trata-se

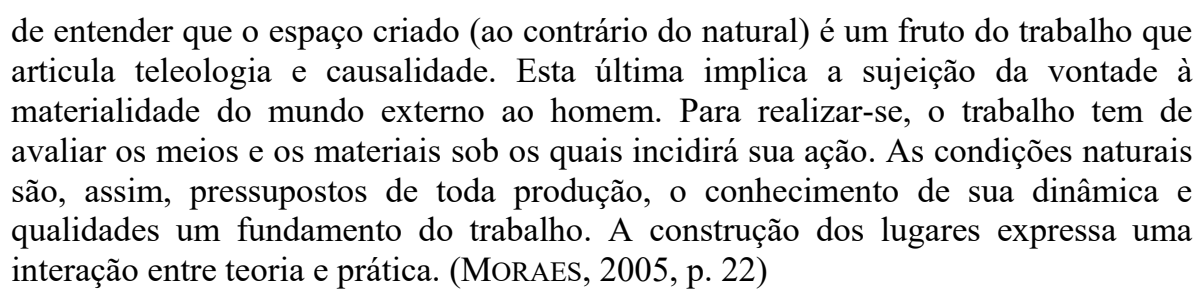

Nesse sentido, diríamos que, com o advento da política nacional centralizada na figura de Getúlio Vargas, a Geografia alinhada aos modernos parâmetros internacionais se institucionaliza e floresce no Brasil com as atribuições de inventariar o território para além da fragmentada escala de atuação das oligarquias regionais e de sugerir, junto a outras especialidades, as melhores estratégias para a execução do plano no âmbito territorial.

\footnotetext{
${ }^{7}$ Cf., a este respeito, a brilhante e aparentemente pouco explorada proposição de Milton Santos ao longo dos itens 12 (“O Espaço, um Fator?”) e 13 (“O Espaço como Instância Social”) de sua Por uma Geografia Nova (2004 [1978]). “O espaço é a matéria trabalhada por excelência. Nenhum dos objetos sociais tem tanto domínio sobre o homem, nem está presente de tal forma no cotidiano dos indivíduos. A casa, o lugar de trabalho, os pontos de encontro, os caminhos que unem entre si estes pontos são elementos passivos que condicionam a atividade dos homens e comandam sua prática social. A práxis, ingrediente fundamental da transformação da natureza humana, é um dado sócio-econômico mas é também tributária das imposições espaciais. [...]O papel ativo do espaço na evolução social e inegável.” (SANTOS, 2004, 185-186)
} 


\subsection{O TERRITÓRIO NACIONAL - OBJETO DE ESTUDO E ESCALA DE ATUAÇÃO}

Ao longo da primeira metade do século XX, um profundo processo de transformação econômica e social pautado pela passagem de uma economia escravista agroexportadora para uma economia assalariada crescentemente voltada ao mercado interno se processou no Brasil. Segundo Furtado (2013 [1959], p. 328), “o desenvolvimento da primeira metade do século XX apresenta-se basicamente como um processo de articulação das distintas regiões do país em um sistema com um mínimo de integração."

Por um lado, observa-se um intenso processo de transformação das geografias regionais preponderantes no território, sua articulação em âmbito nacional e a ascensão não apenas de relações de lógica urbana sobre paisagens até então rurais, como especificamente o predomínio de relações socioespaciais sobre o território nacional articulado a partir de centros de comando sediados na região sudeste do país. ${ }^{8}$ Trata-se, assim, de realidades regionais associadas a relações socioespaciais em transformação. Por outro lado, há o surgimento de uma ramo acadêmico aparelhado para descrever o país e operar sobre o território nacional, mediante o desenvolvimento de um campo de conhecimento independente e capaz de fornecer subsídios necessários para a direção do Estado sobre as transformações em curso.

Pode-se indagar a demora para o desenvolvimento no Brasil de um aparelho voltado à necessidade de se inventariar o território sobre o qual intervém o Estado. Uma hipótese seria o relativo "atraso" da economia brasileira frente às nações industrializadas que, segundo Celso Furtado, não se construiu entre a ascensão da economia cafeeira e o início dos grandes projetos modernizantes da economia brasileira, "mas no retrocesso ocorrido nos três quartos de século anteriores. Não conseguindo o Brasil integrar-se nas correntes em expansão do comércio mundial durante essa etapa de rápida transformação das estruturas econômicas dos países mais avançados, criaram-se profundas dessemelhanças entre seu sistema econômico e os daqueles países." (FURTADO, 2013 [1959], p. 216)

Neste mesmo sentido, Prado Jr. (1981, p. 102) destaca a completa ausência de uma economia propriamente nacional até pelo menos o segundo quartel do século XX. O período

\footnotetext{
${ }^{8}$ A RBG oferece um vasto número de estudos monográficos sobre variadas geografias regionais brasileiras. São poucos, aliás, os exemplares da Revista se nenhum artigo destinado à descrição regional, seja em termos monográficos, seja, de maneira mais recorrente, recobrindo uma faceta específica da região considerada.

${ }^{9} \mathrm{O}$ conceito de "atraso" talvez não seja o mais adequado, tendo em vista a raiz colonial da maneira como o Brasil se inseria no comércio internacional. É improvável que o Brasil tivesse conseguido assumir uma posição protagonista não fossem os três quartos de século de economia decadente que precederam a economia cafeeira. Caio Prado Jr. salienta a ausência de um projeto amplo para o desenvolvimento econômico não atrelado a interesses internacionais e de longo prazo e cita, inclusive, a infraestrutura colonial como um fator indutor do aprofundamento da lógica colonial. (cf. PRADO JR., 1981, p. 298)
} 
colonial não conheceu qualquer sistema organizado de produção e distribuição de recursos com vistas à população nela residente. Entende-se que na ausência de qualquer projeto de desenvolvimento nacional, sob uma lógica de simples expansão extensiva de atividades voltadas à exportação, dentro da qual, aliás, desenvolvem-se os interesses das oligarquias regionais, qualquer investigação sobre o território não justificaria o desenvolvimento de um avultado organismo de Geografia com esta finalidade.

É com a ascensão de Getúlio Vargas, efetivamente, que a preocupação burguesa de controle dos domínios territoriais nacionais ganha significado. Inaugurava-se uma nova etapa do desenvolvimento do Estado nacional brasileiro, na qual o controle do território era parte constitutiva fundamental.

Entre os exemplos de desenvolvimento político observados na Europa e na Ásia, a consolidação do que se pode chamar Estado territorial, "bem como a sobreposição do território do Estado aos vínculos pessoais, como fundamento da unidade das sociedades políticas” (ZIPPELIUS, 1984, p. 38), encontra raízes históricas variáveis. A despeito dos processos específicos de formação destes Estados e da maior ou menor antecedência de sua consolidação, contudo, todos estes substituíram alguma forma de autoridade estatal fundamentada em relações pessoais.

Diferentemente do fato histórico asiático e europeu, contudo, embora o território brasileiro tenha sido estabelecido antes de seu povo, em decorrência do contexto colonial, o poder estatal ancorado no domínio territorial apenas ganha plena efetividade a partir do Estado Novo, centralizado na figura de Getúlio Vargas.

No Brasil, a ruptura com os laços coloniais de dominação implicava a construção de um novo Estado atrelado à construção de uma identidade nacional. Esta identidade era, em si, problemática, frente a variadas formas de coerção social, impregnada de critério racial como conformador de estruturas de poder e com elites econômicas regionais praticamente independentes de um poder centralizado. (MoRAES, 1991) Neste contexto, o princípio de conquista atravessa a formação nacional latino-americana e traz consigo a ideia de que a ocupação dos fundos territoriais não-povoados é o elemento fundante da unidade da nação. Trata-se, pois, da "construção de uma identidade nacional em bases geográficas, isto é, por referência ao território e não à sociedade que o habita.” (MORAES, 1991, p. 171)

A maior importância dada ao território a partir do governo Vargas tem seu sentido. Santos (2004) aponta que a universalização das tecnologias e das multinacionais, dada pelo presente modo de produção, apenas se viabilizaria através da escala nacional, o que atribui um valor particular à estrutura interna de cada país. É apenas através da escala nacional que os 
valores mundiais se expressam ao nível das classes sociais. Assim, as promessas do mundo globalizado ou, como afirma Milton Santos (2004, p. 213), a totalização universal

não pode realizar-se (no sentido de materialização ou objetivação) senão através de uma outra totalização que nos é fornecida por intermédio do conceito de formação econômica e social. Em nossos dias, quando as nações tem a vocação de se tomarem estados, a formação social se confunde com o próprio estado-nação. Na verdade, nenhuma outra categoria poderia ser mais adequada ao estudo do espaço, porque essa categoria permite que não nos afastemos da realidade concreta.

Prado Jr. (1981) se refere a forças arcaicas que vão além de interesses agroexportadores ligados à lógica colonial ainda presentes no período posterior à Crise de 1929. O autor aponta para "a inércia de toda a parte mais importante e substancial da estrutura e organização econômica do país" que se constituiu em função da produção de gêneros exportáveis, e cita "a distribuição da população, a estrutura agrária, a disposição dos centros urbanos, a rede de transportes, até o aparelhamento comercial e financeiro" organizados em termos estranhos às necessidades da comunidade brasileira. (PRADO Jr., 1981, p. 297)

Tanto Santos quanto Prado Jr. utilizam o conceito de "inércia" para se referirem ao papel do "espaço como instância dotada de autonomia relativa" (SANTOS, 2004, p. 159) ou da dimensão geográfica na formação econômica e social brasileira. Santos (2004), no que parece ser o núcleo da argumentação de seu livro, reafirma Prado Jr., em termos universais:

Mas aquela inércia dinâmica de que o espaço é dotado lhe assegura, antes do mais, a tendência a reproduzir a estrutura global que lhe deu origem, ao mesmo tempo em que se impõe a essa reprodução social como uma mediação indispensável que às vezes altera o objetivo inicial ou lhe imprime uma orientação particular. (SANTOS, 2004, p. 186)

Ora, mesmo uma reestruturação conservadora das instituições políticas e da infraestrutura nacional às contingências históricas exige do governo que se dedicar a este objetivo uma política territorial bem definida.

Segundo Zippelius, o território do Estado pode ser pensado do ponto de vista sociológico, em que se revela um momento importante para a integração de uma comunidade. Isto porque o território

é um mundo comum de experiências da vida, um objeto comum de vivências espirituais. Ele é um fator integrador da comunidade política na proporção em que é um momento do destino político coletivo, «na proporção em que constitui, especialmente, um objeto de defesa, de delimitação, do povoamento, do aproveitamento, etc.». É com base no território que se funda uma comunhão de vida política e de valores, sobretudo na medida em que ele também é uma ambiência formada pela coletividade e um «produto cultural». (ZIPPELIUS, 1984, p. 108)

No caso brasileiro, a ausência de povo torna o território elemento indutivo de uma nacionalidade, indução essa carregada de uma ideologia comandada pelo Estado. 


\subsection{CONTEXTUALIZAÇÃO DO ESTADO NOVO}

Uma heterogênea coalização reunindo líderes políticos do Rio Grande do Sul, Minas Gerais e Paraíba ${ }^{10}$ se rebelou militarmente contra o então presidente Washington Luiz e sua intenção em empossar o candidato vencedor das eleições, Júlio Prestes. Mais do que o questionamento da estrutura coronelista que garantiu a vitória de Júlio Prestes, o motivo de fundo foi o fato de Prestes ser paulista, assim como Washington Luiz, desrespeitando-se assim alianças entre facções políticas regionais rivais (SKIDMORE, 2010 [1967]), ancoradas em uma democracia puramente formal. A Revolução de 30, como ficaria conhecido o episódio, pôs fim à República Velha e abriria caminho para “a quebra das 'autonomias' estaduais", elementos fundamentais para a emergência de agências de informação sobre o Brasil em escala nacional.

A Revolução de 30 inaugurou a etapa decisiva do processo de constituição do Estado brasileiro. A quebra das "autonomias" estaduais que amparavam os "polos oligárquicos" resultou numa crescente centralização do poder: concentraram-se progressivamente no Executivo federal os comandos sobre as políticas econômica e social, bem como a disposição sobre os meios repressivos e executivos. O Estado seguirá federativo na sua forma, mas os núcleos de poder local e regional serão subordinados cada vez mais ao centro onde se gestam as decisões cruciais. Esse movimento de centralização e concentração de poder, sob os múltiplos aspectos em que se expressou, conduzirá o Estado brasileiro a uma forma mais avançada de Estado Nacional, capitalista e burguês. (DRAIBE, 2004, p. 54)

Além da considerável força militar angariada pela chamada Aliança Liberal, devido ao apoio de jovens oficiais revolucionários, os tenentes, o elemento crítico para a queda de Washington Luiz e o não-empossamento de Júlio Prestes foi a perda de apoio militar pelo então presidente. De todo modo, os patriarcas políticos dos estados que compunham a Aliança Liberal, cujo candidato à presidência era Getúlio Vargas - organizada partidariamente para disputar a eleição com Júlio Prestes, e que incluía inclusive uma oposição partidária paulista -, não estavam dispostos a liderar uma revolta, fato apenas iniciado com o assassinato do candidato a vice-presidente de Vargas, João Pessoa, por políticos ligados ao grupo político de Prestes. Entre a renúncia de Washington Luiz e a posse de Vargas, um governo militar provisório governaria o país, fenômeno já conhecido, com Exército e Marinha na posição de árbitros políticos na disputa política nacional.

\footnotetext{
${ }^{10}$ Mas também uma pequena e crescente classe média urbana liberal, jovens tenentes dispostos a experimentar formas políticas não-democráticas de modernização institucional e econômica, movimentos sindicais, campesinato e agremiações comunistas, bem como alas conservadoras não-revolucionárias, mas interessadas por um golpe militar, tais como a cúpula militar, a classe de cafeicultores e a elite política marginal excluída do jogo político da República Velha.
} 
Vargas efetivamente transformaria o país em dois sentidos: encerrou a estrutura republicana já esgotada, devido ao colapso de sua estrutura interna e à crise econômica mundial; e de fato levou a cabo um acordo geral de necessidade de reforma do sistema político. Novas formas políticas eram necessárias, ainda que não houvesse nenhum consenso sobre um projeto único. (SKIDMORE, 2010, p. 36-45)

Em meio a um debate político em que formas centralizadas de Estado se antepunham ao liberalismo econômico territorialmente fragmentado, conforme aponta Penha (1993), a Crise de 1929 introduziu a concepção de um Estado mais centralizador e com maior participação "na formulação de políticas econômicas e no seu planejamento". Além disso, assinalou o abandono da teoria do laissez-faire e incentivou "uma postura antifederalista no Brasil, pois se associou este regime ao liberalismo econômico [da Primeira República], considerado ‘pernicioso', pois não levava em conta as ‘demandas da Pátria'.” (PENHA, 1993, p. 42)

As críticas às oligarquias regionais e a associação dessas ao federalismo eram feitas de forma enviesada particularmente pelos pensadores desvinculados da tradição liberal, como Francisco Campos, Plinio Salgado e Oliveira Vianna, com os quais Getúlio Vargas se alinhava.

Em meio a uma convulsionante disputa política, Vargas mostrou habilidade para unir forças políticas opostas, fazendo concessões e promessas, ao mesmo tempo em que levava adiante ações de modernização não apenas no âmbito institucional e econômico, mas também no plano infraestrutural do país. ${ }^{11}$ Penha (1993, p. 43), a este respeito, assinala que a característica marcante do Estado brasileiro neste período "é a contradição da aplicação dos modelos de inspiração liberal e as práticas autoritárias e populistas mais frequentemente do tipo centralizado." Neste ambiente, para o avanço das transformações em curso, diversos setores da sociedade brasileira, em si mesma em rápido processo de transformação, seriam afetados.

O maior controle estatal sobre interesses estaduais nucleados, atrelado à introdução autoritária de uma nova matriz econômica de apropriação territorial ${ }^{12}$, de raiz industrial e

\footnotetext{
${ }^{11}$ Penha (1993), a partir de Ianni (1979), observa que a Revolução de 30, que pode ser considerada "marco do estabelecimento do Estado burguês no Brasil", não implicou, contudo, na "liquidação do Estado oligárquico, mas sim na sua derrota, pois não alterou de forma significativa a sua característica principal: a propriedade fundiária e a estrutura de poder local das oligarquias." (PENHA, 1993, p. 50)

12 É importante frisar que, embora, aparentemente, Getúlio Vargas empreenda um esforço original de modernização infraestrutural e de desenvolvimento de mecanismos administrativos de cooptação política, necessários ao desenvolvimento de uma economia industrial de bens de consumo, seu projeto é fruto do contexto que lhe deu origem, gestado no interior da própria oligarquia e a partir do contexto de reestruturação produtiva em escala mundial. Assim, a república oligárquica que o antecede, além de crescentemente conflituosa entre si, efetivamente se põe como obstáculo ao desenvolvimento urbano-industrial em curso no país. Haviam, ainda, as classes médias emergentes que passaram a exercer pressão política. A inauguração de uma nova fase do capital
} 
urbana, exigiu a ampla organização de novo quadro institucional, fundado numa burocracia de natureza técnica. Segundo Draibe (2004, p. 76), a "acelerada montagem entre 1930 e 1945 do aparelho econômico estatal centralizado obedeceu, na prática, ao princípio de centralização dos comandos e de descentralização funcional ou administrativa." Além de uma ampla reforma ministerial, tal aparelhamento se deu por meio da instauração de políticas gerais, compreendendo regulação e controle das áreas cambial e de comércio exterior, monetáriocreditícia e de seguros; de órgãos destinados a elaborar e implementar políticas de regulação e fomento de ramos de produção e comercialização, em especial de certos ramos agroindustriais, tais como café, açúcar, sal, mate e pesca ${ }^{13}$, além do controle de produção, estoque, preços e distribuição de gêneros alimentícios básicos; de órgãos de caráter consultivo, normativo ou deliberativo, responsáveis por políticas referentes a grandes áreas da atividade econômica ou a esferas mais abrangentes da ação estatal; e de códigos e regulamentações dos serviços de utilidade pública afetos à vida econômica. (DRAIBE, 2004, p. 78-83) No âmbito administrativo, ainda, passaram para o controle estatal o setor de geração e distribuição de energia elétrica; estatização da marinha mercante; e criação de empresas estatais estratégicas no âmbito da exploração e distribuição de minérios e petróleo.

É possível perceber, pela magnitude dessas ações tomadas, a necessidade vital de mecanismos de controle do território, tais como: conhecimento dos aspectos físicos da superfície e do subsolo; dos padrões espaciais da ocupação humana e econômica; e de um ordenamento regional condizente com escala territorial do Brasil, além da cartografação do seu espaço. (ALMEIDA, 2000, p. 65)

Assim, a hipótese de que o Conselho Nacional de Geografia (CNG) talvez tenha sido "o único órgão institucional de caráter geográfico diretamente ligado ao poder central de um Estado" (MONTEIRO, 1980, p. 10) reitera a leitura de que o surgimento do IBGE, dentro deste contexto "caracterizado por um tríplice movimento de centralização, burocratização e racionalização em torno da esfera estatal"14, representou "um novo marco de referência nas relações do Estado com seu território": mais abrangente, moderno e racionalizador. (PENHA, 1993, p. 41)

produtivo no território nacional, portanto, marcada por forte intervencionismo estatal, é fruto de um contexto e da necessidade de um ordenamento da crise, papel assumido por Vargas. (DRAIBE, 2004; PENHA, 1993; SKIDMORE, 2010.)

${ }^{13}$ Quase todos estes produtos receberam algum tipo de tratamento específico por parte de publicações na Revista Brasileira de Geografia, ligada ao IBGE.

14 Cf. DRAIBE, 2004, p. 54-57. A autora realiza uma respeitável leitura histórica dos eventos políticos e econômicos que se estendem da Revolução de 1930 ao Golpe de 1964 e, ao nosso ver, consegue preservar a complexidade de múltiplos fatores históricos em inter-relação. 


\subsection{A GEOGRAFIA JUNTO ÀS PRÁTICAS DO PLANEJAMENTO}

Os materiais publicados pela RBG fornecem indicativos dos eixos que estruturariam o projeto de modernização nacional assumido pelo Governo Vargas no plano infraestrutural, na medida em que, no que cabe à esfera do labor geográfico, este instrumentaliza a ação do Estado sobre o território. Alçado ao poder pela via da não-continuidade democrática, as ações concretas endossadas por Vargas em favor do reconhecimento territorial do país, quando comparadas às iniciativas então existentes, indicam verdadeira ruptura com a consciência geográfica estatal apresentada pelas elites agrárias tradicionais, representantes da República Velha. Soma-se a um universo bastante vasto de aspectos relativos à chamada Era Vargas a participação da Geografia como uma das ciências auxiliares da administração federal que por um longo período atuou como articuladora de outras especialidades.

O enunciado de que a Geografia atuou, historicamente, junto aos círculos de poder é um dos mais destacados da história da disciplina e consagrou, mesmo, vozes como a de Yves Lacoste. Este autor, ao sugerir que a promoção de uma Geografia dos "professores" mnemônica e insípida objetivava mascarar uma Geografia dos "Estados-Maiores", cujo objetivo primeiro seria promover a pilhagem e a guerra, parece desconsiderar uma vasta produção geopolítica na obra de geógrafos franceses como Paul Vidal de La Blache, e de uma Geografia enquanto estratégia e disputa por regiões e territórios. (RIBEIRO, 2010; 2015) Na expansão territorial do capitalismo a geografia foi chamada a representar um papel importante na adaptação das estruturas espacial e econômica dos países pobres às novas tarefas que deviam assegurar sem descontinuidade. Segundo Milton Santos:

Nascida tardiamente como ciência oficial, a geografia teve dificuldades para se desligar, desde o berço, dos grandes interesses. Estes acabaram carregando-a consigo. Uma das grandes metas conceituais da geografia foi justamente, de um lado, esconder o papel do Estado bem como o das classes, na organização da sociedade e do espaço. A justificativa da obra colonial foi um outro aspecto do mesmo programa. (SANTOS, 2004 [1978], p. 31)

Frente a relação tão estabelecida entre o saber geográfico e os grandes interesses e considerando-se ainda a ausência de um plano racional de intervenção sobre o território que marcou tão claramente a história brasileira até o fim da República Velha, pode-se pensar que a emergência de um grande órgão estatístico como o IBGE, de penetração até então inédita no território, teria suprido esta deficiência. O Conselho Nacional de Geografia, nesse sentido, atuaria ao menos como parte substancial de uma influente agência planificadora e, seus geógrafos, como artífices do planejamento. 
Almeida (2000) faz a mais contundente defesa do entendimento do IBGE como órgão de planejamento e afirma, mesmo, logo na apresentação de seu extenso trabalho, que o Instituto consistiu-se na "maior agência de planejamento territorial do governo brasileiro" (ALMEIDA, 2000, p. 19) ${ }^{15}$. Vale destacar que se fala em IBGE e não em ciência geográfica, embora o autor procure focalizar, também, os diferentes momentos da relação entre Geografia e Planejamento. Pedro Geiger, na introdução à obra de Penha (1993, p. 14) é mais discreto ao afirmar que "o IBGE, órgão ligado originariamente ao gabinete da Presidência da República, atuou como se exercesse algumas das funções de órgão central de planejamento." O próprio Penha, por sua vez, ao apontar, no caso brasileiro, a necessária dimensão espacial para a consecução das políticas governamentais em escala nacional, também é explícito na associação entre IBGE e planejamento territorial.

Concebido como importante instrumental técnico-científico de administração do território, a atuação do IBGE foi orientada, assim, a partir de dois vetores: enquanto suporte de funcionamento da máquina estatal no tocante a implementação de políticas públicas e enquanto núcleo administrativo central responsável pelas formulações e execução de políticas territoriais. (PENHA, 1993, p. 19)

Senra (2014) também aponta que Teixeira de Freitas, um dos principais idealizadores do IBGE, teria pensado "a associação dos sistemas estatístico e geográfico a um virtual sistema de planejamento, o que nunca chegou a existir, de fato, mesmo décadas à frente, com a criação de um Ministério de Planejamento e Coordenação.” (SENRA, 2014, p. 16)

Ainda que o IBGE tenha atuado em termos de planejamento territorial em um período em que o termo "planejamento" era considerado subversivo, pois associava-se ao mundo soviético (Geiger, 1988), não se pode, em primeiro lugar, confundir a atuação do IBGE com a da Geografia, embora esta, ao batalhar por sua vinculação junto ao Instituto, assuma a lógica que o presidia. ${ }^{16}$ A prática do planejamento no seio do IBGE, se é que pode ser identificado durante a fase indutiva e empirista do saber geográfico praticado pelo CNG até o fim dos anos 1950, não pode ser confundido com a prática geográfica. A comunidade geográfica ligada ao IBGE apenas em momentos pontuais parece ter assumido o centralismo na tomada de decisões, atuando muito mais justamente no sentido de garantir a participação desta ciência

\footnotetext{
${ }^{15}$ Devido à ausência de paginação, consideramos a contagem das páginas a partir da capa.

${ }^{16}$ Não se pode, com efeito, confundir o pensamento geográfico com as práticas e objetivos "ibegeanos" embora, obviamente, estejam inter-relacionados. Geiger (1988, p. 68) explicita, ainda, o equívoco das novas correntes de pensamento geográfico que confundiram, de forma simplista, "o conteúdo ideológico da epistemologia que se encontra por trás dos métodos quantitativos, com o comportamento de todos que os utilizavam." Dentre outros aspectos nocivos deste movimento, o autor identifica a ausência de "esforços pela adaptação e preservação do espaço geográfico conquistado com a criação do IBGE, uma instituição em constante reestruturação nos anos 70/80." De fato, como veremos, o ambiente geográfico de trabalho no seio do IBGE nunca esteve garantido e foi disputado, podemos dizer, "palmo a palmo" por entusiastas deste saber.
} 
junto às demandas do órgão diretamente ligado ao gabinete presidencial. A constância de serviços de caráter técnico visualizáveis nas publicações da RBG respondiam a determinações estranhas à Geografia no âmbito da Política. A alta cúpula do IBGE, formada por militares, engenheiros e políticos ligados simultaneamente a organizações geográficas tradicionais, embora experiente no jogo político, carecia de um moderno corpo técnico - acessório, de todo modo - para manter-se no poder. (GEIGER, 1988) “As grandes decisões ligadas à gestão do território e as propostas destinadas a influir sobre as estruturas territoriais do País quase nunca partiam dos geógrafos, mas basicamente desta cúpula”. (PENHA, 1993, p. 89)

A relação dos técnicos da área da Geografia com a cúpula decisória, além disso, fornece um argumento adicional que comprova que a área destinada à atuação de geógrafos não estava garantida, mas foi, antes, fruto de conquista no âmbito político-institucional. Isto porque não havia uma ideia precisa, entre o alto escalão, de todas as tarefas que poderiam ser delegadas aos geógrafos. Em expedições, por exemplo, como ao Jalapão (1943), "marco inicial das pesquisas de reconhecimento geográfico do território brasileiro" (ABRANTES, 2014, p. 4), coube a profissionais como o geomorfólogo Francis Ruellan sugerir o envio de geógrafos junto aos engenheiros cartógrafos, dentre eles Pedro Pinchas Geiger. Ruellan, além de professor na Universidade do Brasil, foi consultor do CNG e soube beneficiar a Geografia da vantagem, na época, do fácil acesso à Presidência do IBGE e desta à Presidência da República. (GEIGER, 1988)

Embora, por outro lado, haja uma distância entre a prestigiada e regular prestação de serviços ao Estado por parte da ciência geográfica e a efetiva participação desta nos projetos que incidiriam sobre o território, ainda que este esclarecimento não altere a natureza oficiosa que adquire a ciência geográfica em contribuição de modo mais ou menos complacente junto ao Estado, não se pode negar a fulcral importância desta prestação de serviços para o desenvolvimento do pensamento geográfico, da qual, inclusive, posteriormente emergiria a crítica.

Lamego (2014), ao comentar as memórias da geração de geógrafos que trabalharam no IBGE até a década de 1970, afirma:

Viveram um período em que se questionou pouco, ou mesmo não se questionou, a insistente celeuma sobre a relevância social da geografia. Até mesmo porque, como sugere Neil Smith, a idéia de relevância social está em constante modificação, entrelaçada que é à conjuntura $(1989$, p. 8). E, naquela época, pensavam os geógrafos que, para ser socialmente relevante, precisava a geografia contribuir ativamente para o conhecimento científico em prol do desenvolvimento social e econômico do país. E era o quê se propunham. (LAMEGO, 2014, p. 2, grifo nosso.) 
Apesar do prestígio de se atuar junto ao Estado e supostamente em favor do desenvolvimento nacional comum a uma geração não apenas de geógrafos, parece haver certo consenso de que a ciência geográfica apenas começa a atuar de modo mais explícito em favor do planejamento territorial a partir da adoção dos princípios da Geografia Quantitativa e da modelagem estatística pelo IBGE, em fins dos anos 1960. Segundo Bomfim:

Precisamente nos anos de 1950-60, a geografia brasileira passa a se ater a questões relacionadas à racionalização e organização do território (principalmente em perspectiva regional), numa paulatina mudança de rumos, para o qual se somaram diversas perspectivas teóricas, tais como: a geografia quantitativa (de matriz anglosaxônica), a economia espacial - a exemplo das teses de François Perroux (1967) - e (novamente) a geografia francesa. (BOMFIM, 2014, p. 2)

A reaproximação de geógrafos franceses e brasileiros se deu, precisamente, por conta do XVIII Congresso Internacional de Geografia. Na análise da Geografia praticada em ambos os países nas décadas de 1950 e 1960,

nota-se um afã pela "aplicação" deste campo do conhecimento, doravante reivindicado como uma finalidade intrínseca ao caráter sintético da disciplina, a qual deveria ultrapassar a descrição regional e seu papel ornamental, plausível apenas como elemento de "cultura geral", para ser uma ciência ligada ao planejamento territorial e aos homens de ação (Juillard, 1958; Tricart, 1958). (BOMFIM, 2014, p. 3)

Com a planificação emergiria na Geografia a tentativa de "adequação" da ciência em relação ao mundo industrial. Esta ciência, não mais voltada para estudos de realidade préindustrial, mas comprometida com o "presente", com os rumos do capitalismo, vê-se, por isso mesmo, com a necessidade de lidar com o descompasso entre as nações "centrais" e a ampla "periferia":

Doravante, a geografia (e também a economia, a sociologia, a história...) debruça-se sobre preocupações relativas ao "terceiro-mundo", a superação do subdesenvolvimento surgindo como um escopo central, para cuja consecução justamente - o aménagement du territoire aparecia como meio para chegar a um melhor equilíbrio entra as desigualdades regionais ou como fim, se a memória aqui recordar, menos que a nova geografia, mas sim um determinado uso da análise espacial por ela preconizada. (BOMFIM, 2014, p. 3)

São fases distintas, portanto, de desenvolvimento do labor e do pensamento geográficos. Faissol (1988), apesar disso, argumenta que, provavelmente, fazer planejamento sempre levou em consideração os interesses nacionais, às vezes do povo, às vezes da Nação.

A ideia de planejamento, de uma maneira ou de outra, está sempre presente quando se formulam - ainda que de uma forma muito vaga e até abstrata - o que se costuma chamar de objetivos nacionais, para usar um jargão consagrado na Escola Superior de Guerra. (FAISSOL, 1988, p. 87)

No Brasil, o debate em torno da unidade nacional sempre esteve ligado à diminuição de desigualdades regionais e, por isso, as experiências de Governo a partir da década de 1930 
rapidamente passaram a conter uma dimensão espacial. (FAISSOL, 1988) A própria necessidade de se estender a autoridade estatal a todo o território nacional, superando-se clivagens regionais de poder e extensas áreas vazias do ponto de vista da soberania centrada no Rio de Janeiro reiteram a dimensão espacial do planejamento. Não se pode, assim, desconsiderar trabalhos como a divisão regional do Brasil levada à cabo pelo CNG, já na década de 1940, como um importante marco da aproximação da ciência geográfica com as práticas intervencionistas do Estado sobre o território. Neste caso, além de subsidiar a produção de estatísticas, a nova divisão regional teria importantes desdobramentos a longo prazo no desenvolvimento de novos planos de intervenção estatal.

Reiteramos, frente ao exposto que, pelo menos até os anos 1950, a Geografia não parece efetivamente participar da elaboração das políticas territoriais levadas a cabo pelo Estado, embora tenha protagonizado em serviços como a nova divisão regional, a transferência da capital para o Planalto Central e a delimitação da Amazônia Legal. Sua atribuição maior era de reconhecimento territorial, munindo, justamente, planejadores - mais ligados à Política do que à ciência - de um conjunto de informações sobre a Nação. Estas informações, como se pode depreender da análise conjunta dos materiais publicados pela RBG no período, estão distribuídas em linhas temáticas complementares. (vide TABELA 1) Um adendo a ser melhor explorado, a este respeito, repousa na percepção de que, embora de importância inquestionável em termos geopolíticos no período histórico considerado, as informações de natureza territorial produzidas pela Geografia, ao menos da maneira como expostas nos materiais publicados da RBG, parecem carecer do pragmatismo necessário para atenderem plenamente às aspirações planificadoras estatais.

Faissol (1988), ainda, apesar de estar se referindo ao período pós-Revolução Quantitativa, quando a economia também já apresenta bases mais complexas, aponta para o caráter meramente consultivo da Geografia frente ao Planejamento e indica que os métodos estatísticos tiveram o mérito, ao menos, de apontar à ciência geográfica a ausência do elemento político em suas análises regionais. Ao tratar a sociedade apenas como mais um elemento dentre tantos na composição da singularidade regional, o geógrafo teria deixado de incorporar em seu método um elemento político que daria às regiões históricas seu conteúdo essencialmente histórico. Essa limitação teórica da Geografia impediu-a de dar respostas satisfatórias à questão de que "regiões historicamente definidas - que o sistema capitalista procura subordinar à lógica do mercado - são capazes e, somente elas, de oferecer uma resistência" (FAISSOL, 1988, p. 87) às forças homogeneizadoras, questão essa que o Planejamento não poderia deixar de considerar. 
Ademais, a representatividade de um conjunto de descrições em um universo muito amplo de possibilidades, bem como o estabelecimento de inter-relações entre múltiplos fenômenos, eram problemas que o modelo regional-descritivo não resolviam, quando solicitado pelos modelos estatísticos.

Tais questões situam-se mais claramente no período subsequente ao coberto pelo presente trabalho. Tornar-se-ão objetos de crítica pela historiografia geográfica e serão apontadas como alguns dos fatores limitantes da explicação geográfica sobre a realidade. No que tange às duas primeiras décadas de contribuições geográficas, o fato é que o entendimento sobre o homem "apenas" como um elemento a mais na paisagem, característica essencial do modelo regional francês de pesquisas, atendia tanto às necessidades estatais, quanto às aspirações oligárquicas regionais.

Para o setor cultural liberal hegemônico, impregnado de tradições da sociedade agromercantil e bem representado no núcleo do Departamento de Geografia da USP, a Geografia "possibilista" permitia atacar o ascendente racismo então alimentado por correntes fascistas, que condenavam o desenvolvimento econômico no meio tropical, mas atacava também os movimentos socialistas e suas referências às determinações históricas, mediante apelo à neutralidade positivista. "O homem escolhe, mas entre as possibilidades que o meio oferece. Não é pois da história e na história que se fazem as opções, mas do meio natural, determinações geográficas ao invés das históricas.” (GEIGER, 1988, p. 70)

Há a considerar, ainda, os significados simbólicos: a valorização das unidades regionais ideográficas correspondia a resistências partidas do mundo agromercantil à centralização praticada pelo Estado Novo, à transferência de recursos da agricultura para a industrialização. (GEIGER, 1988, p. 70)

Mas ao poder central também interessava uma ciência neutra e naturalista, visível também na produção geográfica soviética. A Geografia Física atendia às necessidades de levantamento de recursos e de sustentação da ideologia do cientificismo como agente modernizador. A Geografia Humana, por sua vez, deveria fornecer o máximo de informações descritivas, detalhadas para o suporte da administração, evitando-se polêmicas ideológicas. Já em termos regionais, de um lado,

a concepção vidalina excluía a relação dos problemas regionais com o processo econômico-social do país como um todo. Por outro lado, uma divisão regional hierarquizada, segundo unidades físicas, expressaria a divisão do território como instrumento do controle e da operacionalização de projetos econômicos pelo poder central. (GEIGER, 1988, p. 71)

Frente ao exposto, resume Penha (1993): 
Deste modo, a influência alemã ratzeliana, ligada à questão de coesão nacional, vem complementar uma concepção geográfica francesa, bem ao gosto da burguesia liberal que temia os radicalismos. Um exemplo dessa complementação pode ser encontrado nos primeiros números da própria Revista Brasileira de Geografia onde aparecem os artigos de Pierre Deffontaines de um lado, descrevendo a dimensão continental do Brasil, enfatizando que a moldura do quadro natural comanda a organização das atividades humanas e, de outro, a Geografia dos transportes, do engenheiro Moacir Silva, instrumento de integração nacional, por excelência. (PENHA, 1993, p. 89)

Assim, ao menos durante sua fase empirista, ao longo da qual gozou de maior prestígio, a Geografia não parece ter ofertado menos do que lhe foi solicitado, da mesma maneira que não encontramos referências para descrever, com clareza, sua participação na concepção dos projetos estatais de intervenção sobre o território.

Uma pesquisa por documentação primária sobre os projetos de intervenção sobre o território levados a cabo pelo Estado seria necessária, mas há indícios de que, ao menos em alguns projetos o próprio Estado - "arquiteto da infraestrutura material para o território" (BomFIM, 2014, p. 2) - atuou de maneira secundária na sua concepção e na eventual exploração de dividendos. Penha (1993), ao comentar o financiamento por empresas privadas de expedições geográficas promovidas pelo IBGE, afirma que expedição ao vale do São Francisco, por exemplo, realizada entre julho e setembro de 1943 pelos geógrafos Jorge Zarur e Orlando Valverde, além de aplicar o método da "análise regional" aprendida por Zarur em Wisconsin, nos EUA, foi resultado

de um convênio entre o CNG e o "National Planning Association", importante organização econômica norte-americana que pretendia investir grandes somas de capital no melhoramento do vale, visando a aproveitar o seu potencial econômico, à semelhança do que se fizera no vale do rio Tennessee, na década de 30. (PENHA, 1993, p. 95)

Frente ao provável fato, a ser melhor esclarecido, de que mesmo o Estado brasileiro talvez não tivesse total controle sobre a concepção de suas políticas territoriais, é possível que nossa persistente preocupação em diferenciar a concepção de um projeto da "mera" coleta de dados para viabilizar sua execução seja, mesmo, de menor relevância. A questão de fundo é se a ciência geográfica efetivamente fornecia materiais suficientes para a planificação estatal, tendo em vista o teor pouco prático de numerosos materiais publicados pela RBG. Em que medida a descrição geográfica efetivamente subsidiou a ação estatal? Ou: os materiais publicados pela RBG efetivamente retratam a contribuição da ciência geográfica junto ao Estado ou são produtos intelectuais produzidos a partir de dados, estes sim, estratégicos e, em alguma medida, sigilosos à sociedade civil? A hipótese que levantamos é que, talvez, o oportunismo da primeira comunidade geográfica brasileira, que lutou pela institucionalização 
mediante a fundação de departamentos universitários e de uma agência com uma ala geográfica no seio do Estado, tenha sido, efetivamente, mais vantajoso para a própria Geografia do que para o Estado. A descrição territorial, de todo modo, era historicamente associada ao labor geográfico, não sendo difícil justificar sua atribuição aos geógrafos. Neste processo, quem mais teria ganho foi o próprio pensamento geográfico.

\subsection{A FORMAÇÃO DO INSTITUTO NACIONAL DE ESTATÍSTICA ${ }^{17}$}

\subsubsection{Antecedentes}

O território brasileiro demorou séculos para conhecer qualquer apreciação significativa de sua ordem compósita, seja em termos demográficos, seja em relação aos seus recursos naturais. Durante o período colonial, preocupações tardias voltaram os olhos para a questão fronteiriça, beneficiando-se a metrópole do fato de que a Coroa espanhola dispunha de poucas condições materiais para pôr em dúvida de fato os limites nacionais que se desenhavam.

Segundo Gonçalves (1995, p 9), no Brasil o “primeiro levantamento [censitário] digno de crédito foi efetuado pelo Conselheiro Antônio Rodrigues Velloso de Oliveira, após a elevação da Colônia à categoria de Reino, e em consequência de Resolução de 24 de junho de 1818 [...] No juízo de Joaquim Norberto de Souza e Silva foi 'o primeiro censo da população do País, pela sua aproximação da verdade, pelo possível esmero de sua organização e pela fé que se pode nele depositar'."

O Ministro dos Negócios do Império, Paulino José Soares de Souza, enquanto deliberava a realização do censo de 1870, restrito à Capital do Império, “demanda a Joaquim Norberto de Souza e Silva, funcionário do ministério, um amplo estudo da população" (SENRA, 2009, p. 62), cujo resultado foi publicado com o título Investigações sobre os recenseamentos da população geral do Império e de cada província de per si tentados desde os tempos coloniais até hoje. ${ }^{18}$

Segundo Senra (2009, p. 74), Joaquim Norberto, em seu relatório, diz ter havido cinco censos na Corte, antes daquele a ser realizado nos meses seguintes.

17 Vide ANEXO B. Linha do tempo com os principais eventos e instituições acadêmicas e burocráticas diretamente relacionadas à institucionalização da ciência geográfica no Brasil.

${ }^{18}$ SILVA, Joaquim N. de Souza e. Investigações sobre os recenseamentos da população geral do Império e de cada província de per si tentados desde os tempos coloniais até hoje. Rio de Janeiro: Tipografia Perseverança, 1870. 167p. Anexo ao Relatório apresentado à Assembleia Geral na abertura da segunda sessão da décima-quarta legislatura, pelo Ministro e Secretário de Estado dos Negócios do Império, Paulino José Soares de Souza. 
O primeiro, em 1799, mandado fazer pelo Vice-rei D. José Luís de Castro (1744-1819), o Conde de Rezende, por ordens vindas de Portugal. Foi publicado, na Revista do n, em 1858, sob o título Almanaque Histórico da Cidade de S. Sebastião do Rio de Janeiro, cobrindo as quatro freguesias da cidade.

O segundo, em 1821, já de retorno a Portugal, D. João VI manda fazer outro censo, sob a direção do Ouvidor Joaquim José de Queiroz (1774-1850), com vistas à indicação dos deputados às Cortes portuguesas.

Em 1838, Bernardo Pereira de Vasconcelos (1795-1850), Ministro dos Negócios do Império, na Regência Una de Pedro de Araújo Lima, o Marquês de Olinda, manda fazer outro censo, o terceiro.

Em 1849 virá o quarto censo, feito por Haddock Lobo (1817-1869), com auxílio do Ministro dos Negócios da Justiça. Esse censo, a julgar pela data, teria valido como experiência ao já embrionário censo geral, em 1852, em meio às mudanças na economia brasileira. Haddock Lobo, segundo Joaquim Norberto, enfrentou e superou naquela tarefa "grandes dificuldades e enormes obstáculos", em mais de oito meses de trabalho.

O quinto viria em 1856, feito pelo Chefe de Polícia, Antônio Thomaz de Godoy, por ordem do Ministro dos Negócios da Justiça. Dele não ficou nenhum número, havendo quem diga que fracassou. (Cf. SENRA, 2009, p. 74.)

Como se vê, não se pode falar em ausência de atividade estatística no Brasil prérepublicano. Uma rápida pesquisa sobre as publicações da RBE revela trabalhos estatísticos de relativa importância em Rio Grande do Sul, São Paulo, Rio de Janeiro, Espírito Santo, Minas Gerais e Bahia. ${ }^{19}$ Uma pesquisa mais extensiva pode revelar outros esforços. Não há, no entanto, um esforço verdadeiramente nacional antes daquele empreendido em 1872.

Já em inícios do século XIX, Milliet (1955), citando documentos de época relativos à capitania de São Paulo, aponta que o interesse por recenseamentos nas diversas unidades administrativas da colônia era mínimo. Isso porque, em primeiro lugar, "não interessava ao administrador da colônia o futuro social da raça mas tão sòmente o surto econômico imediato do país.” (MillieT, 1955, p. 145). Taunay (1953) indica como o interesse estatístico se ligava quase tão-somente à finalidade de arrecadação. Ademais, limitados à escala da vila, quando muito de uma freguesia, visando à administração local, os recenseamentos encaravam um cenário de pouca fixação do homem à terra e grande mobilidade social. Para medir tal

\footnotetext{
${ }^{19} \mathrm{Cf}$., de forma complementar, artigos históricos publicados ou reproduzidos na RBE, especialmente: TAUNAY, Affonso de E. Velhos censos. Revista Brasileira de Estatística, Rio de Janeiro: IBGE, v. 14, n. 53, p. 39-41, 1953; MILLIET, S. Recenseamentos antigos. Revista Brasileira de Estatística, Rio de Janeiro: IBGE, v.16, n. 62, p. $144-150,1955$.
} 
fenômeno, teria de se enfrentar ainda uma "colônia pobre de recursos financeiros, vazia de mercados consumidores, deserta de meios de comunicação", porém rica de possibilidades para aventureiros em busca de enriquecimento rápido. Mesmo as pessoas de posse, fixadas nas vilas, sonegavam informações, fruto de um amplo conflito de interesses entre o Governo e os colonos livres. Os próprios administradores locais se recusavam ou manipulavam solicitações provenientes dos governadores, em favor de seus interesses pessoais ou da elite local. (MilLiet, 1955, p. 146)

Para Senra (2006), sequer o poder necessário para a organização estatística estava suficientemente institucionalizado no Brasil. "A tradição colonial portuguesa não constituíra um território brasileiro centralizado; não havia uma unidade brasileira. Grandes regiões relacionavam-se diretamente com Lisboa", cidades e vilas eram independentes em relação às sucursais do poder real estabelecidas no país. (SENRA, 2006, p. 47) ${ }^{20}$

O cenário de grande desprezo pelas estatísticas muda, evidentemente, com a mudança da Corte portuguesa para o Brasil. Ao adquirir a colônia foros de metrópole, todos aqueles empecilhos coloniais tornam-se objeto de atenção direta da Coroa, incluindo aqueles de natureza estatística. Menos de um mês em solo brasileiro, cria D. João uma aula de Economia Política, a primeira do mundo nessa matéria, sem, no entanto, jamais ter saído do papel. O professor eleito, José da Silva Lisboa, Visconde de Cairu, publicaria um livro $^{21}$ uma década mais tarde, pela Imprensa Régia, no qual associaria Economia Política e Estatística.

Senra (2009) aponta para uma característica geral do período imperial brasileiro, marcado pelo reconhecimento, por parte de alguns indivíduos ligados à administração do Império, da necessidade da produção de estatísticas tanto em qualidade quanto em abrangência sem, no entanto, significativo sucesso das tentativas, todas elas, de todo modo, de empenho reduzido.

Diversos foram os motivos para o fracasso das estatísticas durante o período imperial. O fracasso da "Comissão de Estatística Geográfica, Natural, Política e Civil”, criada em 1829, por exemplo, é atribuída à dificuldade de se adquirir informações do interior do país, ou à pobre formação estatística de seus técnicos. Houve, posteriormente, em 1850, tentativa mais concreta que, no entanto, fracassou devido à revolta popular, no Norte, de mestiços crendo que seriam contados para serem escravizados.

\footnotetext{
${ }^{20}$ Cf. também mesma passagem na v. resum. de SENRA, 2009, p. 24.

${ }^{21}$ LisboA, José da Silva. Estudos do Bem Comum e Economia Política, ou ciência das leis naturais e civis de animar e dirigir a geral indústria e promover a riqueza nacional e prosperidade do estado. Rio de Janeiro: Ipea/INPES, 1975. (Série Pensamento Econômico Brasileiro)
} 
De modo geral, a própria formação colonial brasileira explica a demora para a organização da produção estatística sobre o Brasil, cujos obstáculos se estendem do poder político fragmentado à sensível inexperiência administrativa dos governantes em relação ao bem público, passando pela grande carência técnica e infraestrutural que marcou a vida na Colônia.

Em meados do século XIX, o poder público passa a sentir a crescente necessidade de um órgão centralizador dos serviços estatísticos. Nesse sentido, o Ministro da Agricultura, Comércio e Obras Públicas, João Lins Vieira Cansanção de Sinimbu encarregou José Cândido Gomes, considerado um dos precursores da sistematização da estatística no país, de planejar as bases para a organização da estatística, medida alcançada em 20 de dezembro de 1862 . "Estruturado com base na organização dos serviços de estatística da Bélgica, elaborada por Adolphe Quetelet, e nos da França, por Moreau de Jonnés, o estudo apresenta uma proposta geral para a organização da estatística nacional, devidamente adaptado às circunstâncias específicas do país.” (OliveIRA, 2005, p. 26) Segundo Gonçalves (1995, p. 10), a “ideia básica do projeto era centralizar a estatística no Ministério da Agricultura, cabendo a execução a uma diretoria, com ramificação nas províncias, sob tríplice hierarquia administrativa, policial e eclesiástica."

A mais elaborada proposta até então não foi levada adiante. Ainda não desfrutando de dados de todas as províncias, nem de precisão em relação aos dados obtidos, em 1870 conseguiu-se atrair a atenção do Governo para as estatísticas. "Lei n. 1.829, de 09.09.1870, que estabelecia, no artigo $1^{\circ}$, a periodicidade decenal para o recenseamento, determinando no artigo $2^{\circ}$ a criação da Diretoria Geral de Estatística - DGE. Nesse mesmo ano ocorreu a execução de um censo da população do Município Neutro, sede do Governo Imperial.” (GONÇALVES, 1995, p. 11)

A realização decenal estava de acordo com as recomendações internacionais adotadas em Bruxelas (1853) e Londres (1860), e reiteradas em São Petersburgo (1872). Outras questões técnicas também obedeciam às deliberações internacionais. (VARNHAGEN, 1946, p. 380) ${ }^{22}$

A DGE, criada em 1871, com subordinação ao Ministro e Secretário de Estado dos Negócios do Império foi o órgão central mais bem sucedido até então, a primeira instituição brasileira de estatística, de caráter público e nacional. A importância maior da Diretoria reside no fato de estar na raiz institucional do IBGE.

\footnotetext{
${ }^{22}$ A RBE reproduziu, em 1946, o relatório do diplomata em serviço em Viena (Áustria), Francisco Adolfo de Varnhagen, o Barão de Porto Seguro, sobre sua participação no XVIII Congresso Internacional de Estatística, realizado em São Petersburgo em 1872. A leitura do Relatório permite inferir que os responsáveis pela organização das estatísticas brasileiras estavam a par das determinações internacionais. Ver: VARNHAGEN, F. A. de. O Congresso Estatístico de S. Petersburgo em agosto de 1872. Revista Brasileira de Estatística, Rio de Janeiro: IBGE, v. 7, n. 26, 1946, p. 378-387.
} 
"Malgrado inúmeras dificuldades surgidas no decorrer dos trabalhos, a operação censitária obteve relativo êxito" (GONÇALVES, 1995, p. 11). A operação iniciada em $1^{\circ}$ de agosto de 1872 pode ser considerada o primeiro recenseamento da população brasileira e os valores registrados na época, corrigidos em 1877 segundo relatório da DGE, foram os únicos resultados significativos, de âmbito nacional, produzidos pelo Império. Ainda se fariam, em diversas províncias, tentativas de organização de tabelas estatísticas.

Divulgados os resultados, a DGE entrou prontamente em crise. Segundo Senra (2009), os próprios conhecimentos relativos à estatística eram escassos, mesmo em termos internacionais, a despeito da realização dos Congressos. Em termos nacionais, a situação se agravava com o pouco pessoal qualificado para a coleta, sistematização e divulgação dos resultados, bem como pelo próprio pouco uso das estatísticas, ainda não suficientemente incorporadas à burocracia estatal. Com pouca verba e baixo nível de capacitação, a produção estatística de qualidade também era escassa, fortalecendo a tese de sua pouca utilidade.

A realização do Censo de 1880 foi postergada a ponto de não ser realizada. Daí a decisão por se reduzir a DGE, que perdeu sua condição de órgão autônomo, para se tornar uma seção anexa à $3^{\mathrm{a}}$ Diretoria da Secretaria de Estado dos Negócios do Império. Tal desmonte inviabilizou a realização do Censo de 1880, mesmo quando adiado para 1887.

Apenas com a República, retoma-se o interesse pelas estatísticas, restaurando-se a antiga DGE em 1890, agora atrelada ao Ministério do Interior. Apesar do novo governo, a DGE foi efetivamente restaurada, recuperando-se o regulamento promulgado em 1871. Apesar disso, meses depois, ela é reestruturada, o regulamento para a realização do Censo sofre alterações e os recursos são sensivelmente reduzidos. Mesmo assim, iniciou-se o segundo recenseamento da história do Brasil, no mesmo ano; sua apuração e publicação dos resultados mostraram-se, contudo, extremamente lentos, por motivos múltiplos, seja falta de pessoal, de recursos ou revoltas políticas. Por questões administrativas, em um constrangedor “jogo de empurra”, o DGE passou para a incumbência, antes, para o Ministério da Agricultura, depois para o Ministério da Indústria, Viação e Obras Públicas, ao qual coube, já em 1900, a divulgação do último volume de dados. Em 1897, a Diretoria ainda sofreria nova reforma, sendo reduzida sua estrutura.

O diretor Timóteo da Costa, em balanço ao Ministro dos Negócios do Interior, expressou toda a dificuldade encontrada para a aquisição de informações junto aos estados, estes recebendo as solicitações com extremo desdém. Para tentar vencer a displicência e resistência estaduais, a DGE, com o quadro já reduzido, procurou enviar pessoal especializado junto aos órgãos estaduais, sem, contudo, angariar maiores frutos. Para Senra (2009, p. 105), 
nada "favorecia a realização do censo, e adiá-lo teria sido de bom senso. Ao realizá-lo os dirigentes da estatística secundavam a inexperiência administrativa dos dirigentes do Governo Provisório."

Com o governo de Campos Salles, aprofundou-se o cenário negativo para um órgão de estatística federal que vislumbrava continuidade e sistematização de procedimentos. Data desse governo a adoção da "política dos governadores". "Agora, a desatenção completa-se, seja na definição das prioridades, que nem sempre valorizava as estatísticas, seja na criação das suas próprias repartições estatísticas, sem nenhum vínculo com a DGE, invocando-lhe independência." (SENRA, 2009, p. 112)

Apesar do cenário tão adverso, crítico em tantas circunstâncias, não se deixou de realizar o recenseamento de 1900. Com objetivos inicialmente ampliados em relação ao anterior, mas com verba bastante reduzida, mesmo dados demográficos simples não foram obtidos com êxito junto aos estados.

"Bastante deficiente e moroso, o Segundo Recenseamento Decenal da República teve apuração incompleta dos dados, somente terminada em 1908." (GONÇALVES, 1995, p. 12) Os resultados relativos ao Distrito Federal foram anulados, devido à constatação da grande imperfeição dos dados coletados. A despeito das falhas gerais, tal levantamento era o único material sobre o qual o governo republicano poderia se debruçar. Sua importância era formal, embora pouco levada à sério, por definir, segundo a Constituição republicana de 1891, a participação representativa de cada estado de acordo com sua população na composição da Câmara dos Deputados.

Em 1907, a DGE foi reestruturada e passou a ser dirigida pelo demógrafo sanitarista José Luiz Saião de Bulhões Carvalho ${ }^{23}$, considerado o fundador geral da estatística brasileira. Segundo Senra (2009, p. 117), Bulhões “terá pleno sucesso no intento da reforma de estrutura, e terá sucesso apenas parcial no intento de obrigar os estados a responder às demandas da DGE.” Em relatório sobre a situação encontrada em 1907, quando assumiu, Bulhões aponta para os trabalhos relativos ao recenseamento de 1900 bastante incompletos e completamente paralisados. A recuperação desse trabalho visava, antes de tudo, retomada de ritmo visando ao Censo de 1910.

Uma das principais iniciativas de Bulhões Carvalho foi a criação, no âmbito da DGE, do Conselho Superior de Estatística - CSE, órgão consultivo composto de delegados de todos

\footnotetext{
23 "Médico dedicado aos combates sanitários, à frente da revista Brasil Médico, publicação da Academia de Medicina, aplicara-se aos estudos da demografia sanitária, dessa forma, sendo usuário crítico das estatísticas publicadas pela DGE.” (SENRA, 2009, p. 124)
} 
os estados, representantes do Congresso Nacional e membros de vários segmentos da sociedade. (OliveIRA, 2005) Foi o primeiro passo concreto rumo à racionalização da produção estatística no Brasil, segundo um princípio de descentralização produtiva coordenada por um órgão central.

Presidido pelo ministro da Indústria, Viação e Obras Públicas, o Conselho teria por
finalidade obter a máxima unidade de vistas no tocante às classificações,
nomenclaturas e outros itens estatísticos, mediante a adoção de modelos idênticos
para a coleta e a remessa de informações da mesma categoria. Os delegados
estaduais procurariam obter dos respectivos governos informações uniformes no que
dissessem respeito à divisão territorial e à administração, de acordo com os modelos
estabelecidos pela Diretoria Geral de Estatística. Esse conjunto de dados conferiria
unidade à produção das estatísticas nacionais. (OLIVEIRA, 2005, p. 32)

A primeira mesa do CSE, foi formada por grandes homens públicos, de formação estatística reduzida, porém, com prestígio junto às diversas instâncias com quais se lidaria. (SENRA, 2009, p. 127) ${ }^{25}$ As necessárias reuniões regulares da CSE, contudo, nunca ocorreram.

Seus esforços maiores, porém, de articulação entre as diversas escalas administrativas com vistas a racionalização de um serviço estatístico sistemático, esbarrou na falta de cooperação interestadual e no desinteresse de cooperação com um órgão central orientador. (PENHA, 1993, p. 67) "Para dar fim a essa situação nefasta, Bulhões conseguiu a aprovação do Decreto $\mathrm{n}^{\mathrm{o}} 1.850$, de 02 de janeiro de 1908, a primeira do gênero no Brasil. Por ele, 'todas as autoridades civis ou militares, associações, empresas, companhias, estabelecimentos industriais, comerciais e outros e os particulares' ficavam obrigadas a prestarem as informações que lhes fossem pedidas pela Diretoria Geral de Estatística." (SENRA, 2009, p. 128) Tal medida não surtiu qualquer efeito significativo e, na ausência de Bulhões à frente da DGE, nenhuma solução foi sequer pensada para o problema. Sua adoção apenas se efetivaria com o governo Vargas.

Sobre a patente questão federalista a limitar as atividades estatísticas, vale a pena citar um comentário de Senra acerca da reformulação imposta à DGE, meses depois de sua reativação enquanto Diretoria de âmbito federal:

A DGE segue com quatro seções (Art. $2^{\circ}$ ) [...]. Já entre as funções do Diretor Geral
(Art. $4^{\circ}$ ), ainda que também rotineiras, valerá destacar a seguinte: '§ $7^{\circ}$ Procurar
alargar a esfera das investigações estatísticas e requisitar os dados e esclarecimentos
de que carecer a repartição, para o que poderá dirigir-se às autoridades e corporações
públicas do País, excetuados os Ministros de Estado'. Pois, ao longo de 30 anos,
desde então, será enorme a distância entre requisitar e ser atendido. (SENRA, 2009,
p. 102. Grifo nosso.)

${ }^{24}$ Cf. PeSSOA, Heitor E. A. A cooperação disciplinada e os recentes progressos da estatística no Brasil. Revista Brasileira de Estatística, Rio de Janeiro: IBGE, v. 1, n. 1, 1940.

${ }^{25}$ Ainda sobre o CSE, cf. SENRA, 2009, p. 125-129; 134-137. 
Apesar disso, Bulhões Carvalho "proporcionou uma fase de trabalho intensivo; foram coligidas informações relativas ao ensino em todo o território nacional e os resultados da pesquisa publicados em 1916, no volume Estatística da Instrução.” No mesmo ano, era lançado o primeiro de três volumes do Anuário Estatístico do Brasil, publicação destinada a ser o mais importante veículo de informações estatísticas do País.

Esses volumes estabeleceram os critérios básicos de organização temática e apresentação tabular que, com os necessários aperfeiçoamentos, seriam mantidos até os nossos dias pela publicação. Para a época, os levantamentos estatísticos já revelam um trabalho de larga envergadura. (GONÇALVES, 1995, p. 12)

Afastado da DGE em 1909 por questão de saúde, Bulhões, e também todo o país, não veria a realização do Censo de 1910, em decorrência "da escassez de recursos e da crise político-militar determinada pela eclosão da Revolta da Chibata [...]. Este censo seria o primeiro a pesquisar as atividades econômicas do país, já que o seu regulamento previa uma investigação sumária desses elementos.” (OLIVEIRA, 2005, p. 33)

Ainda em 1910, a DGE foi transferia para o Ministério da Agricultura, Indústria e Comércio. No ano seguinte, a Diretoria passaria a se chamar Diretoria de Serviço de Estatística - DSE. Em 1915, Bulhões Carvalho retornaria à Diretoria - onde se manteria até 1931 - incumbido de organizar o Censo de 1920, terceiro da República, quarto da história do país. Desagradou-lhe as duas reformas sofridas pela Diretoria no período em que esteve afastado e realizou nova reforma. ${ }^{26}$

Até 1920, os Recenseamentos Gerais no Brasil limitavam-se, quase que
exclusivamente, à contagem da população, ou seja, ao aspecto demográfico. Em
1920, ensaiaram-se esquemas de mensuração de outros aspectos da realidade
nacional, mas ainda de maneira incompleta. Esse levantamento revestia-se de
especial importância porque, entre outros motivos, a divulgação dos seus resultados
deveria coincidir com as comemorações do Centenário da Independência do Brasil,
a realizar-se em 1922. (OLIVEIRA, 2005, p. 34-35)

Houve, ainda, uso inédito da propaganda junto à população e aos meios de comunicação em favor da atividade censitária. Além de ampla publicidade impressa, em diversos veículos, contou-se com a participação de múltiplos setores, “como a Igreja Católica (dos altos prelados aos simples párocos e vigários), as associações operárias, as associações patronais, os clubes (por exemplo, dos aviadores, então em moda), das forças armadas, dos órgãos públicos federais, entre outros. Nesse esforço de propaganda, vale marcar a direta atuação do Presidente da República, Epitácio Pessoa.” (SENRA, 2009, p. 161) A realização da Exposição Universal Comemorativa do Centenário da Independência forjou o estímulo final para a

\footnotetext{
${ }^{26}$ Sobre as reformas anteriores ao retorno de Bulhões Carvalho, bem como a reforma por ele efetuada, cf. SENRA, 2009, p. 137-144.
} 
realização de um recenseamento, acima de tudo, de qualidade. Neste sentido, utilizou-se também, pela primeira vez, equipamentos Hollerith para a mais rápida apuração dos resultados.

Pode-se afirmar que a centralização política e o amplo aparelhamento administrativo que seriam promovidos por Getúlio Vargas colocam a produção estatística brasileira em um patamar muito superior ao registrado até então. As propostas lançadas por Bulhões Carvalho para o Censo de 1910, realizadas apenas parcialmente em 1920, apontam para uma sofisticação da análise estatística e para a possibilidade de investigação que superam uma descrição limitada aos números. Com o primeiro volume do Anuário Estatístico do Brasil, publicado em 1916, surge, pela primeira vez no âmbito oficial, considerações acerca do território, em termos não apenas numéricos. Há referências, por exemplo, a questões astronômicas e climáticas e a divisões políticas, judiciárias e administrativas.

O Censo de 1920 atestou grande maturidade intelectual, mesmo para os padrões registrados posteriormente. Pensou-se detalhadamente em cada estágio do trabalho e no Distrito Federal se realizou, antecipadamente, o mapeamento de amplas seções eleitorais. De fato, trabalho cartográfico similar deveria ser feito nas unidades estaduais, inclusive em escalas diversas, trabalho este, contudo, de envergadura ainda muito além das possibilidades. Como sempre, contou-se, portanto, com pessoas familiares às localidades na orientação do trabalho censitário. ${ }^{27}$

Em março de 1920, atendendo a convite de Bulhões Carvalho, Mário Augusto Teixeira de Freitas 28 "assumiu o cargo de delegado geral do Recenseamento em Minas Gerais, exercendo-o até o ano seguinte." Neste pequeno período, organizou o primeiro sistema estatístico estadual tecnicamente organizado articulado às esferas municipal e federal. "Ele também elaborou um eficiente sistema de gerenciamento de informações que cobria todos os municípios mineiros" (OLIVEIRA, 2005, p. 36) cujo legado, além de informações estatísticas, resultou em um mapa de cada município recenseado.

Em seu minucioso relatório enviado a Bulhões Carvalho, sob o título O Recenseamento de 1920 em Minas Gerais, Teixeira de Freitas não apenas relata o processo censitário, como avalia o processo e apresenta “observações, experiências e sugestões sobre problemas

\footnotetext{
${ }^{27} \mathrm{O}$ serviço cartográfico vinculado a uma agência oficial de informação começava a se organizar, à época, via confecção de gráficos junto à DGE. (Cf. SENRA, 2009, p. 173-176.) Posteriormente, veremos, o trabalho cartográfico visando ao Censo de 1940 seria uma das principais atribuições do Conselho Nacional de Geografia em seus primeiros anos.

${ }^{28}$ Além do vasto trabalho de Senra (2006), há diversos outros trabalhos sob autoria, organização ou orientação do mesmo autor sobre o período que se estende da realização do Censo de 1920 à criação do IBGE, em 1938. Consultar o sítio: <http://www.convenio1931.ence.ibge.gov.br/>, para acesso a documentos originais e textos recém-publicados sobre a temática, incluindo republicações de trabalhos de Teixeira de Freitas.
} 
econômicos, sociais e políticos da realidade mineira". No documento, deixa clara a importância da estrita articulação entre as diversas esferas de poder.

Da sua atuação como delegado do Recenseamento em Minas Gerais, Teixeira de Freitas foi convidado a reformular a organização da estatística estadual, com plena "liberdade de atuação como diretor do Departamento Estadual de Estatística do Estado de Minas Gerais. Ele assumiu o cargo em 1922, nele permanecendo até 1930." (OLIVEIRA, 2005, p. 37)

Além de colaborar com importantes reformas educacionais no estado, Teixeira de Freitas publicou número significativo de trabalhos de natureza estatística, cujo elevado grau de sistematização é incontestável.

Por sua vez, Bulhões Carvalho, ainda à frente da Diretoria Geral de Estatística, não abandonara as idéias que trazia das suas experiências anteriores, e cujo eixo era a necessidade de cooperação técnico-administrativa entre a União e os estados, visando eliminar a dispersão reinante nas atividades estatísticas a cargo de diferentes órgãos. (OLIVEIRA, 2005, p. 38)

Em janeiro de 1930, Bulhões Carvalho lança, na Conferência de Propaganda do Recenseamento de 1930, uma bem fundamentada proposta de cooperação interadministrativa com vistas ao aperfeiçoamento das estatísticas nacionais. Seu argumento procurou demonstrar que a unificação de estatísticas na esfera federal não feria a autonomia estadual, nem configurava intervencionismo por parte do poder federal. Para tanto, cita o modelo alemão, lançado após a derrota de 1870 e aperfeiçoado desde então, amparado na descentralização geográfica. Apesar de otimista, reconheceu contudo as dificuldades que teria de enfrentar para alcançar as centenas de municípios brasileiros, se tivesse de se amparar na realidade política da época.

No mesmo ano de 1930, o então diretor do Serviço de Estatística Geral de Minas Gerais, Mario A. Teixeira de Freitas, encaminhou um estudo de reformulação do serviço estatístico nacional com 33 indicações para serem apreciadas na $1^{\text {a }}$ Conferência Nacional de Estatística, convocada para 12/10/1930, mas também não realizada em virtude dos acontecimentos políticos daquele ano. (PENHA, 1993, p. 68)

Teixeira de Freitas gozava de prestígio no meio estatístico tendo em vista o ótimo trabalho realizado no estado de Minas Gerais ao longo de oito anos. Em sua proposta, também argumentava em favor da unificação da atividade estatística, a evitar a dispersão e duplicação de resultados. A “organização dos serviços estatístico-geográficos em Minas Gerais significou um importante laboratório experimental baseado no princípio da cooperação intergovernamental destinada a uma gestão mais racionalizada do território mineiro." Isto porque Minas, apesar de um orgulho regional que depositava fé em seu desenvolvimento, "sofria com clivagens regionais em seu território, fruto de condições de mercado e de 
acidentes geográficos", daí o esforço de coordenação exigido para a realização dos levantamentos. Suas diversas indicações, embora depositárias das iniciativas pioneiras de Bulhões, serviriam de base para a posterior organização do serviço estatístico de âmbito nacional. (PENHA, 1993, p. 68-69)

Sem alteração de fato até a década de 1930 do modelo pouco efetivo de produção estatística nacional, a partir de então se experimentará uma realidade em termos totalmente diversos, em bases muito superiores e diretamente tributárias dos apelos e trabalhos de pessoas como Bulhões Carvalho e Teixeira de Freitas. Atender-se-ia, enfim, a solicitações como a de Francisco de Assis Mascarenhas, o Marquês de São João da Palma, em 9 de maio de 1826, em debate no Senado do Império, quando defende a formação de uma comissão de estatística: "É um dos maiores trabalhos, que temos a fazer, e talvez o mais importante; porque sem termos a estatística, como conheceremos o Brasil?” (BRASIL, 1827b apud SENRA, 2009, p. 49)

\subsubsection{Aprovação e instalação do INE, sem Geografia}

Os esforços de Bulhões Carvalho serviram de embrião ao anteprojeto de criação do Instituto Nacional de Estatística - INE. A partir de 1931, com o Governo Provisório, vê-se que a criação do Ministério do Trabalho, Indústria e Comércio - MTIC, incluiu em sua estrutura o Departamento Nacional de Estatística - DNE, que assumiu os encargos da DGE, do extinto Ministério da Agricultura, Indústria e Comércio - MAIC, e da Diretoria de Estatística Comercial, do Ministério da Fazenda - MF. "Este Departamento, criado para centralizar as estatísticas geradas, permaneceu, até ser extinto, numa situação ambígua, pois as duas Diretorias que lhe deram origem continuavam atuando isoladamente." (PENHA, 1993, p. 70-71) Além disso, não excluiu a produção estatística de outras repartições federais, estaduais e municipais, mas tornou-se responsável pela correção dos elementos e informes visando a publicação de anuários.

Também em 1931, dentro da nova estrutura ministerial do Governo Provisório, Teixeira de Freitas, atuando junto ao Serviço de Estatística da Educação e Cultura, ligado à recémcriada Diretoria Geral de Informações, Estatística e Divulgação, do Ministério da Educação e Saúde Pública - MESP, contribuiu ativamente no sentido de fixar normas gerais para um sistema estatístico de âmbito nacional. Tal Diretoria constituiu um marco na história das estatísticas no Brasil, ao concretizar a tão almejada cooperação interadministrativa entre as 
esferas políticas - objeto aliás perseguido há anos por Bulhões Carvalho e cuja proposta seria formalmente apresentada na não-realizada $1^{\text {a }}$ Conferência Nacional de Estatística, marcada para dias antes do golpe que derrubou Washington Luiz da presidência da República. Efetivou-se, enfim, a primeira "experiência governamental de cooperação interadministrativa entre os governos dos estados e da União. Essa experiência se concretizou por ocasião do Convênio Interadministrativo firmado no Rio de Janeiro em dezembro de 1931", patrocinado por Vargas e inclusive com sua presença na reunião inaugural. (PENHA, 1993, p. 70)

A experiência bem sucedida do Convênio resultou em propostas de extensão de seus princípios para toda a estatística brasileira, congregando em um sistema único todos os serviços estatísticos.

Frente à ausência ou defasagem de estatísticas, quando não contraditórias, devido à pulverização dos esforços até então existentes, além de produtos cartográficos ausentes ou de qualidade pífia, Heitor Elói Alvim Pessoa, último chefe de seção da antiga DGE e então diretor da $1^{\text {a }}$ seção da Diretoria de Estatística do MESP, encaminhou a Teixeira de Freitas um ofício propondo uma Lei de Estatística. Pessoa considerava o momento de reforma legislativa ideal para a aprovação de uma lei que, acima de tudo, garantisse a obrigatoriedade de fornecimento de informações de natureza estatística por parte das esferas estadual e municipal, verdadeiro "calcanhar de Aquiles” do sistema estatístico nacional.

Dois meses depois, Teixeira de Freitas encaminharia um ofício ao ministro da Educação e Saúde Pública, Francisco Campos, endossando a solicitação de Alvim Pessoa. No dia seguinte, o ministro solicita a Teixeira de Freitas um anteprojeto de lei. Levaria 6 meses para que Teixeira de Freitas encaminhasse ao ministro, não um anteprojeto de lei, mas um elaborado estatuto orgânico do que propunha ser o Instituto Nacional de Estatística e Cartografia - INEC, ligado diretamente ao gabinete do Presidente e não a um ministério. Neste documento, expõe-se seis ordens de problemas relacionadas ao quadro de desorganização estatística nacional e propõe-se nove itens visando à reestruturação do sistema. Teixeira de Freitas solicita a Campos, ao fim do documento, que o projeto seja submetido à avaliação de Leo de Affonseca, à frente do DNE, afeto ao MTIC, e à dos demais ministros.

As medidas voltadas para aproximação entre os serviços estatísticos e cartográficos em um único sistema, contudo, não vingaram, seja, supostamente, por reação contrária da 
Academia Brasileira de Ciências (SENRA, 2014, p. 4) ${ }^{29}$, seja por hesitação dos técnicos em relação à instalação de um serviço cartográfico. (SOARES, 1939, p. 97) ${ }^{30}$ Segundo Penha:

Esta proposta, porém, defrontou-se com a hesitação dos especialistas quanto à instituição do sistema geográfico, mesmo que limitado aos serviços de cartografia territorial. Argumentavam eles que a centralização dos serviços estatísticos e cartográficos numa única super-repartição acarretaria um poder absoluto da União em detrimento da atuação dos órgãos regionais (estaduais). (PENHA, 1993, p. 70)

Paralelamente a isso, assumiria Juarez Távora o Ministério da Agricultura, em dezembro de 1932. Tão logo assumiu o ministério, ressentiu-se o ministro da falta de informações sobre a pasta que deveria comandar. Ciente do sucesso da diretoria de estatísticas educacionais do Ministério da Educação, solicitou auxílio de Teixeira de Freitas para organizar uma diretoria análoga. Da ajuda, nasce a Diretoria de Estatística e Publicidade DEPu, em 1933, mais tarde Diretoria de Estatística de Produção - DEPr (1934).

Desta aproximação, surge também o apoio de Juarez Távora ao projeto de criação de um instituto que congregasse estatística e cartografia. Atendendo às solicitações dos ministros da Educação e da Agricultura, Teixeira de Freitas elaborou um anteprojeto de lei visando à integração e ao aparelhamento dos serviços estatísticos do país.

Apresentado diretamente ao Chefe do Governo Provisório e com seu apoio, o anteprojeto de Teixeira Freitas foi submetido a uma Comissão Interministerial, designada por Juarez Távora. O anteprojeto teria sido proposto em seu formato original, ou seja, propondose a articulação de serviços cartográficos aos estatísticos. Frente, porém, à resistência quanto à inclusão da cartografia, foi reformulado, restringindo-o à estatística. (PENHA, 1993) ${ }^{31}$ A

${ }^{29}$ Senra (2014, p. 4, nota 2) oferece outra interpretação para o obstáculo à criação de um instituto que congregasse estatística e cartografia. "A ideia não vingou por reação contrária da Academia Brasileira de Ciência [sic], tendo à frente Alberto José Sampaio, que queria criar um órgão nacional de geografia. A proposta de Teixeira de Freitas poria obstáculo a essa pretensão que, contudo, acabaria não se concretizando, por falta de recursos financeiros." Observe mais adiante que, segundo Penha (1993) e o IBGE (1939), a ABC teria tentado, de fato, a criação de um Conselho Nacional de Geografia, após sugestão de Emmanuel de Martonne, como condição para ingresso na UGI, porém, após tentativa frustrada, teria passado a incentivar a criação de um órgão junto ao poder público.

Vale ressaltar, ainda, a vagueza presente em diversas publicações em torno da não-incorporação da Cartografia ao INE, com base na proposta de 1931. Fala-se em "alheamento à ideia", "pressupostos equivocados" e "má vontade" (IBGE, 1939b, p. 7), mas também falta de "ambiente propício" para tamanho empreendimento. (OBSERVADOR ECONÔMICO, 1949, p. 131)

${ }^{30}$ SoARes, José C. de Macedo. Atividades do Instituto Brasileiro de Geografia e Estatística. Revista Brasileira de Geografia, v. 1, n. 1, 1939, p. 97 (Noticiário.) Trata-se do discurso inaugural do Presidente do IBGE, na cerimônia de instalação da primeira sessão das Assembleias Gerais do CNE e CNG, no salão de Conferências do Palácio do Itamaraty.

${ }^{31}$ Há certa imprecisão em relação à resistência na inclusão da cartografia no anteprojeto. Pelo que se pôde compreender da confrontação dos diversos textos dedicados ao assunto, o estatuto orgânico do INEC elaborado por Teixeira de Freitas teria sido encaminhado à Alvim Pessoa em 1932, que o submete ao crivo dos demais ministros. Alguns "técnicos" (quem, especificamente?) teriam sido contrários à inclusão da cartografia (porque?), bem como pela própria ABC (SENRA, 2014). Freitas teria insistido em sua proposta original, por intermédio de Augusto Capanema e Juarez Távora, o segundo endossando a proposta. Submetida à uma 
partir da nova proposta, a Comissão, ao longo de quatro meses e dezesseis reuniões, reelaborou-a e apresentou o projeto de criação do Instituto Nacional de Estatística - INE. (IBGE, 1939a, p. 13), dando destaque para a necessidade de forte planejamento articulado entre as esferas, porém, fortemente centralizado com vista à unificação e promoção dos esforços. O INE seria fruto da articulação de repartições centrais, instituições filiadas e do Conselho Superior de Estatística - CSE.

O sistema de federação dos órgãos estatísticos comportava duas classes repartições centrais e instituições filiadas. A composição da primeira abrangia as quatro diretorias existentes na época: Diretoria de Estatística Geral, subordinada ao Ministério da Justiça e Negócios Interiores, Diretoria de Estatística Econômica e Financeira, do Ministério da Fazenda, Diretoria de Estatística da Produção, da Secretaria de Estado da Agricultura, Diretoria de Informações, Estatística e Divulgação, da Secretaria de Estado da Educação e Saúde Pública, e o Departamento de Estatística e Publicidade, subordinado ao Ministério do Trabalho, Indústria e Comércio.

O quadro das instituições filiadas agrupava os demais órgãos estatísticos federais, estaduais ou territoriais, as organizações, ou simples agendas municipais, dedicadas ao levantamento da estatística geral das comunas e, ainda, os serviços mantidos pela iniciativa privada, incorporados por meio de convênios especiais ou de uma Convenção Nacional de Estatística.

Um órgão de cúpula - Conselho Superior de Estatística - atuaria em todo o sistema nacional, com a responsabilidade de orientação técnica e direção dos órgãos colegiados, auxiliado pelos conselhos regionais. (GONÇALVES, 1995, p. 28$)^{32}$

Além do relatório final, a comissão também encaminhou a Juarez Távora um esboço de lei, sob autoria de Teixeira de Freitas. O projeto sofreu, contudo, forte resistência de alguns dirigentes da esfera federal, em especial do ministro da Fazenda, Osvaldo Aranha. Sua alegação recaía especialmente sobre a questão orçamentária necessária para a concretização do projeto, apontando para a ilegalidade do "fundo especial" requerido (PENHA, 1993) e para a pressão sobre as contas do Governo (OLIVEIRA, 2005). O fato é que a atenção às estatísticas ainda não era consensual no plano político-administrativo.

Frente ao impasse, em junho de 1934, após réplica de Teixeira de Freitas aos ministros reticentes à proposta, o Ministro da Agricultura Juarez Távora, com a força que o cargo lhe revestia, encaminhou ofício direto ao Chefe do Governo Provisório, replicando, ponto a ponto, o parecer de Oswaldo Aranha, o mais resistente à criação do INE, e apontando para o elevado grau de desorganização do país que, em comparação a outros países do continente, colocava-se em patamar inferior. Távora tinha pressa, por temer que a aprovação da nova

comissão interministerial, o projeto teria sofrido nova resistência no que tange à cartografia. Este segundo episódio de resistência é o mais obscuro. A ele se refere claramente apenas Penha (1993, p. 70), que faz referência à Mendonça (1979), referência essa não localizada. Freitas teria então retirado a cartografia do projeto, para que o mesmo fosse enfim aprovado, mas buscou a inclusão da cartografia por outro caminho, indireto, obtendo sucesso.

${ }^{32}$ Cf. também SeNRA, v. 2, 2009, p. 669-681; 2014, p. 4-5. 
Constituição, que recuperaria parte do esquema federalista, obstaria a aprovação do Instituto. Porém, diante de tal arguição, Getúlio Vargas, três dias após o envio do ofício, assinaria o Decreto n. 24.600, de 6 de julho de 1934, criando o Instituto Nacional de Estatística, sem cartografia, extinguindo, automaticamente, o Departamento Nacional de Estatística. Sua definitiva implantação, todavia, ocorreria apenas dois anos depois, bem como a Junta Executiva que comandaria as atividades do órgão até a organização do Conselho Nacional de Estatística - CNE.

O Decreto de criação do INE atribuiu a este a necessária autonomia, diretamente subordinada ao Presidente da República, para operar uma ampla reforma do sistema estatístico nacional que, além de articular os diversos serviços estatísticos já existentes no âmbito federal, dependia de acesso sistemático e racional aos registros estatísticos de âmbito estadual e municipal. Tal ampla coordenação de esforços, em múltiplas escalas, seria conduzida pelo ainda inexistente Concelho Nacional de Estatística.

O Instituto, além de dados referentes às esferas federais, teria de articular e ter acesso também aos registros estaduais e municipais, usufruindo da total autonomia administrativa e técnica necessária para a reforma estatística nacional. Essa função administrativa e articuladora do INE se manteve quando este evoluiu para a forma do IBGE, cabendo aos Conselhos a coordenação técnica dos serviços estatístico e geográfico. Conforme Almeida:

\footnotetext{
Sua estrutura de representações que contemplava todas as instâncias de governo, caracterizava o que podemos definir como Agência do Poder Central Capilarizada, isto é, um órgão de informações diretamente subordinado ao Gabinete da Presidência da República e com alcance até a instância municipal, mas com um aspecto importante: as decisões sobre suas estratégias de ações eram tomadas de forma colegiada num Conselho Superior de Estatística. Apenas para fins de comparação, as agências do Departamento de Correios e Telégrafos também apresentavam alta capilaridade, apesar de não possuírem tal representatividade junto ao poder central. (ALMEIDA, 2000, p. 71)
}

Decretada a criação do INE em 6 de julho de 1934, no entanto, sua instalação apenas ocorreria em 29 de maio de 1936. Para tanto, Teixeira de Freitas aproveitou-se de um evento fortuito. Tratou-se de uma

solicitação imperiosa das relações internacionais do Brasil, obrigando o Conselho Federal de Comercio Exterior a promover a uniformização dos dados estatísticos oficiais referentes a vida brasileira, pois a incoerência entre eles era assombrosa e vinha colocando o País em situação particularmente embaraçosa. (SOARES, 1939, p. 98)

José Carlos de Macedo Soares, chanceler do Itamaraty, viu-se na necessidade de organizar algumas estatísticas comerciais de modo a apresentá-las em negociações internacionais com banqueiros. 
Juntam-se os diretores temáticos de estatística, e se lhes pede um esforço especial, quase sobre-humano. Todos atendem ao chamado e colaboram. Teixeira de Freitas [...] fala do estado da atividade estatística brasileira, a gerar vazios dessa ordem, e insiste no imperativo da instalação do Instituto. Macedo Soares teria ficado convencido, e falado com Getúlio Vargas, que o convida a assumir a presidência da nova instituição. (SENRA, 2014, p. 7)

Nomes já vinham sendo buscados desde o decreto de fundação do Instituto. Todos os nomes pensados possuíam trânsito político, característica tida como essencial para a concretização das múltiplas articulações exigidas pelo novo órgão. Ao ser convidado por Getúlio Vargas, o ministro das Relações Exteriores recusou o convite. Mesmo no exterior, foi novamente convidado pelo Chefe de Estado que, apesar da nova recusa, nomeia-o Presidente do cargo em meados de 1935.

A partir da instalação do INE, "uma Junta Executiva assumia a direção geral do novo órgão, até sua constituição e regulamentação, na dependência da aprovação da Convenção Nacional de Estatística.” (GonÇALVES, 1995, p. 28)

Uma vez instalado o INE, com Macedo Soares assumindo seu novo cargo, iniciativa fundamental seria filiar e coordenar órgãos estatísticos estaduais, mediante realização de uma Convenção Nacional de Estatística, com presença de representantes das instâncias federais e de todos os governos estaduais. Um grande pacto daí originou-se, ratificado por decreto do Presidente, articulando-se, criando-se e orientando-se iniciativas, acordos e mecanismos para coleta e sistematização racional de dados. ${ }^{33}$

$\mathrm{O}$ pacto firmado sobrepunha-se às supostas tendências desagregadoras do federalismo, retirando deste modelo os elementos de ação considerados necessários para o definitivo encaminhamento das questões básicas nacionais, obedecendo ao princípio consagrado no qual 'a descentralização executiva reforçava a unidade do sistema'. (PENHA, 1993, p. 72)

Instituído como um órgão colegiado, o CNE era composto por duas ordens de entidades: as organizações federais e as organizações regionais ou estaduais. Vale observar que, em nível estadual, apenas São Paulo, Minas Gerais, Rio Grande do Sul, Bahia e Pernambuco ${ }^{34}$ possuíam serviços de estatística, cabendo ao $\mathrm{CNE}$ ampla reformulação dentro dos parâmetros desejados. Em 1939, todos os estados já dispunham do serviço. Já em 1940, todos os 1574 municípios já dispunham de órgão dedicado apenas à estatística. (PENHA, 1993)

A partir de 1942, no contexto do "Estado de Guerra" e sob pretexto de segurança nacional, os serviços estatísticos municipais foram transferidos para controle direto do IBGE, em parte devido à dificuldade financeira enfrentada pelos municípios menores, em parte para

\footnotetext{
${ }^{33}$ Cf. subitem seguinte, "1.4.4. Antecedentes ao CNG”, para informações detalhadas sobre a Convenção.

${ }^{34}$ Estranhou-me a não referência ao estado do Rio de Janeiro, já que o Distrito Federal foi o único município a contar com recenseamentos relativamente sistemáticos desde o período imperial.
} 
facilitar o eventual uso das estatísticas pelas Forças Armadas. "Segundo Teixeira de Freitas, os resultados obtidos com a 'nacionalização' das agências de estatísticas foram altamente satisfatórios." (PENHA, 1993, p. 73) Isso por conta do melhor preparo e remuneração dos técnicos ligados diretamente ao Instituto.

\subsubsection{Serviços geográficos no Brasil pré-Vargas}

Para estudos voltados à melhor compreensão da consolidação da chamada Geografia moderna no Brasil, Camargo (2009) alerta para a distância existente entre o processo narrado a partir da perspectiva da memória dos agentes envolvidos na própria construção da História do IBGE e a análise historiográfica dos fatos. Sem desmerecer a valorização da memória institucional, o autor alerta, contudo, que abordagens tradicionais, à semelhança do fenômeno observado nos relatos pessoais, tendem a recuar a presença da ciência geográfica unida à atividade estatística, na consecução das pretensões estatais, à data mais longínqua possível, ou seja, ao momento da elaboração do primeiro anteprojeto de Teixeira de Freitas, em 1931. Neste sentido, tende a alocar Teixeira de Freitas como uma das grandes figuras fundadoras da atividade geográfica no seio do IBGE.

O curto período que separa a instalação do INE e sua união à repentina criação do Conselho Nacional de Geografia - CNG pode reforçar a impressão de que os serviços estatístico e geográfico estariam ligados, desde algum momento no passado remoto, a apelos de natureza teórica ou prática. O fato é que, a despeito dos fortes apelos de Teixeira de Freitas quanto à conveniência do desenvolvimento cartográfico para fins estatísticos, o financiamento do labor geográfico junto ao Estado era ainda menos consensual do que a necessidade de estatísticas para a maior racionalização e capacidade de atuação da administração pública. Ademais, a ciência geográfica, embora historicamente relacionada à cartografia, não se resume a isso.

Diferentemente da atividade estatística brasileira, cuja demanda pode ser identificada com nitidez a partir da migração da corte portuguesa para o Rio de Janeiro, a demanda por atividade geográfica é difusa e de difícil delimitação histórica. Há referências, contudo, a atividades muito anteriores às preocupações estatísticas e alguns historiadores chegam a identificar como primeira atividade geográfica em solo nacional a expedição de reconhecimento de dez léguas de costa marítima empreendida por Pedro Álvares Cabral, dois dias após seu desembarque. (MATOS, 1939, p. 4) Por outro lado, a instalação do CNG em 
1937, cuja concepção ainda não estava presente no anteprojeto de Teixeira de Freitas de constituição do INEC, elaborado nos meses finais de 1931, configura a fundação de uma grande instituição de pesquisa cujo ineditismo divide espaço com sua aparição repentina. Efetivamente, a atividade geográfica que seria praticada pelo CNG foi rapidamente acoplada ao INE quando nada mais apontava para esta direção.

Apesar do rearranjo dos setores oligárquicos ao panorama político varguista, a ruptura da ordem patriarcal estabelecida, após três séculos de domínio, lançou novos ares sobre a interpretação da realidade e possibilitou o surgimento de verdadeiros clássicos sobre a sociedade brasileira. No âmbito da Geografia, Andrade (1994) observa que, de um ponto de vista não ortodoxo, de fato é possível identificar-se uma variada produção literária de cunho geográfico durante o longo período pré-Vargas. O autor admite uma periodização acerca da literatura de âmbito geográfico, dividida em quatro momentos, cuja fase final, já a partir da década de 1930, é marcada, enfim, pela fundação do CNG, das Universidades de São Paulo e do Distrito Federal e pelo desenvolvimento do pensamento geográfico de raiz francesa. Antes disso, já se experimentava no Brasil raciocínios de natureza propriamente geográfica, muito ao sabor das Sociedades Histórico-Geográficas, de autodidatas com formação em universidades europeias e dos interesses de classe que se sustentavam sobre ideologias geográficas.

A primeira fase seria representada por cronistas coloniais, sem critério metodológico definido e dependente de necessidades específicas que, no entanto, forneceram um panorama geral sobre diversos aspectos da realidade colonial brasileira. Em seguida, já no século XIX, ganharia destaque a figura do viajante estrangeiro que, à serviço dos interesses das grandes nações europeias, registraria compêndios sobre a natureza e sobre a ocupação do território. Também cientistas, dentre eles numerosos brasileiros, realizaram estudos regionais sobre elementos de interesse para o desenvolvimento econômico, já durante a Primeira República.

A possibilidade de identificar-se atividades geográficas já no momento do desembarque dos primeiros colonizadores europeus, ao mesmo tempo em que se reconhece a demora para surgir um órgão oficial dedicado à ciência geográfica, convergem para o reconhecimento do que se entendia por objeto da ciência geográfica e por labor geográfico no seio do IBGE. Não há, de fato, uma distância absoluta entre o que se identifica com o labor geográfico anterior à fundação do CNG e o que este Conselho assumirá como tarefa. E a fundação do CNG está necessariamente relacionada à elaboração da base cartográfica sem a qual o significado das estatísticas relativas ao território desvaneceria. 
Entre as diversas motivações que levaram indivíduos ao estudo da realidade, pode-se fazer referência, sem dúvida, às expedições de reconhecimento territorial realizadas nas mais diversas circunstâncias históricas. Trabalhos de natureza corográfica, cuja função primordial amparava-se na localização e descrição de topônimos, estão na raiz da atividade geográfica enquanto atividade científica e, por isso mesmo, não estão ausentes entre os geógrafos do CNG. Aliás, elaboradas e rigorosas expedições geográficas fizeram parte da rotina do CNG até meados da década de $1960 .^{35}$

O Cel. Jaguaribe de Matos, então consultor técnico do Diretório Regional do CNG em Mato Grosso, em 1939, ofereceu um retrospecto das atividades consideradas geográficas no país e fica clara a relação entre o que se entende por atividade geográfica e produção cartográfica. Embora óbvio, é válido afirmar que apenas as expedições de reconhecimento territorial que legaram registros escritos foram citadas pelo autor. A este respeito, inclusive, Matos afirma:

Mostra o genial Humboldt que, muito provavelmente, houve expedições portuguesas, que deixando embora conhecimentos práticos sobre as terras visitadas, não lograram registo nos fastos das explorações geográficas. (MATOS, 1939, p. 5)

Por coincidência ou não, todos os episódios dignos de citação, na visão de Matos, contribuíram para o desenvolvimento cartográfico relativo ao território nacional. Trata-se de expedições de reconhecimento da costa, de ocupação da margem de rios ao Norte e, ao longo do século XVII, o século das bandeiras, "que deixaram roteiros escritos ou verbais, constituindo elementos indecisos ou seja, uma Geografia mais ou menos nebulosa." (MATOS, 1939, p. 10)

Varnhagen, por exemplo, oferece, em 1851, uma nova edição, revisava, do que seria a mais antiga e completa descrição do Brasil, o Tratado Descritivo do Brasil de 1587, de autoria de Gabriel Soares de Sousa. Embora datado de 1587, uma edição completa da obra apenas foi publicada em 1825, ainda assim bastante imprecisa. Coube a Varnhagen confrontar pelo menos 20 cópias distintas, espalhadas por diferentes bibliotecas europeias, para resgatar o autor, o título e o ano de publicação da edição original. Varnhagen comenta na introdução à obra de Gabriel Soares de Sousa (1851, p. 14):

O nosso autor [Gabriel Soares] é singelo, quase primitivo no estilo, mas era grande observador, e, ao ler o seu livro, vos custa a descobrir se ele, com estudos regulares, seria melhor geógrafo que historiador, melhor botânico que corógrafo, melhor etnógrafo que zoólogo.

35 Cf. Abrantes, 2014; AlmeidA, 2000, esp. p. 607-633 (Anexos). 
Como decorrência de sua observação acurada, resultou um trabalho bastante descritivo, de grande valor para o período, que o inscreve como trabalho geográfico.

Para Matos (1939, p. 10), o início dos levantamentos sistemáticos do território brasileiro ocorreu em 1729, com a convocação de peritos matemáticos da Companhia de Jesus para a elaboração de cartas regionais dos sertões por onde se espalhavam os garimpos. Entre 1730 e 1737, um trabalho de grande envergadura reconheceu mais de 200 latitudes por áreas que se estendem de Goiás a Santa Catarina.

Os desdobramentos econômicos no interior ainda inóspito do Brasil, bem como as riquezas incalculáveis já extraídas na América espanhola incitaram a cobiça de ambas as coroas e tiveram desdobramentos políticos.

Alexandre de Gusmão, ministro de D. João V, visando a manutenção da paz, encarregou-se da definição das terras pertencentes às duas coroas. Assim, em 1749, surgiu a primeira carta oficial do Brasil, o Mapa dos Confins do Brasil com as Terras de Espanha na América Meridional, ancorada no princípio do uti-possidetis, posteriormente utilizada como subsídio para o Tratado de Madri de 1750, preparado com as informações obtidas pelos jesuítas e o roteiro da expedição do Sargento-Mor Francisco de Melo Palheta, em 1722, ao rio Madeira. Do problema do estabelecimento de uma linha divisória entre os domínios de Espanha e Portugal, participou também Marques de Pombal, substituto de Alexandre de Gusmão.

Como desdobramento do tratado básico de 1750, foram exigidas muitas outras expedições, cujos levantamentos avolumaram extraordinariamente as informações topográficas, corográficas e iconográficas relativas ao Brasil e que, aparentemente, não tiveram alcance para além dos círculos militares. Diversos levantamentos sequer chegaram a ser incorporados a tempo da assinatura do Tratado de Santo Ildefonso de 1777, que anulou o Tratado de Madri, e seguem aparentemente desconhecidos do público comum. ${ }^{36}$ Não houve à época, assim, pressão por parte das classes sociais livres que se desenhavam no Brasil no sentido de aprofundamento destes trabalhos.

Segundo Gonçalves (1995, p. 21) “as primeiras iniciativas públicas no sentido de levantar a cartografia do País datam de 1808, época da criação do Arquivo Militar e da Impressão Régia." Em termos de obras impressas, Corografia Brasílica, de 1817, é o primeiro livro publicado contendo todos os acidentes topográficos conhecidos até então. Seu autor, Pe. Manoel Aires de Casal, retornou a Portugal com a Corte, em 1823.

\footnotetext{
36 "Pode admitir-se, pois, que para as contingencias geográficas, existe uma única grande campanha de demarcação, evoluindo no século XVIII, de 1751 até ao final do século, a qual constituiu o período áureo da geografia colonial.” (MATOs, 1939, p. 14)
} 
Já no século XIX, Gonçalves (1995) faz referência às expedições estrangeiras de caráter científico como contribuintes da atividade geográfica no Brasil.

Em 1889, Francisco Inácio Homem de Melo, catedrático de Geografia no Colégio Militar, publicou um Atlas do império do Brasil, remodelado e corrigido vinte e três anos depois. Deve-se a ele o registro das áreas nacionais e províncias em quilômetros quadrados, ao invés de léguas quadradas, sistema usado naquela época.

No século XX, a Comissão de Linhas Telegráficas e Estratégicas de Mato Grosso ao Amazonas, mais conhecida como Comissão Rondon, nome de seu chefe, notabilizado como um dos maiores desbravadores brasileiros, trouxe inestimável contribuição não só no âmbito da geografia, como da geodésia e da etnologia. (GONÇALVES, 1995, p. 21)

Ao longo das primeiras décadas do século XX observam-se trabalhos de natureza geográfica dispersos por diversas instâncias da administração pública, como subsídio para a realização de trabalhos específicos. Em termos cartográficos, a organização de mapas topográficos era atribuição da Comissão da Carta Geral do Brasil, do Ministério das Relações Exteriores, organizada em 1900, e do Serviço Geográfico Militar, criado mais tarde, reunidos em 1932 sob a denominação de Serviço Geográfico e Histórico do Exército. O Ministério da Marinha mantinha atividades correlatas à sua esfera de atuação.

É nebulosa, pois, a raiz de uma demanda pública por atividades de natureza geográfica. A começar pelo que se entende por atividade concernente à ciência geográfica.

\subsubsection{Cartografia na Seção de Estatística Territorial}

Matos (1939, p. 7), ao referir-se ao século XVI e XVII, afirma que nesse "tempo, como ainda hoje, para muitas regiões do Brasil, o caráter informativo das cartas era muito mais importante que o da precisão geométrica." Esta dupla vocação - delimitar e informar - parece ser a característica principal que credencia as expedições essencialmente corográficas desde o período colonial a serem colocadas na raiz da atividade geográfica realizada pelo CNG.

Quanto ao Conselho Nacional de Geografia, segundo a Secretaria Geral do IBGE, especificamente:

Duas ordens de fatos determinaram a criação do Conselho: uma, a série de iniciativas em torno da adesão do Brasil à União Geográfica Internacional; outra, o conjunto de medidas empreendidas para a constituição no país de um organismo de coordenação das atividades geográficas brasileiras. (IBGE, 1939a, p. 9)

Em relação à adesão do Brasil à UGI, a participação brasileira no Congresso Internacional de Geografia, realizado em 1931, em Paris, incitou os geógrafos brasileiros a promoverem uma Geografia que ia além das preocupações com a toponímia, através de novos 
conceitos de pesquisa geográfica. (PENHA, 1993, p. 74) Em 1933, Emmanuel de Martonne, Secretário Geral da UGI, em visita ao Brasil, formulou um convite formal junto à Academia Brasileira de Ciências - ABC:

O eminente Prof. De Martonne, em seu discurso de agradecimento, [...] declarou, quanto à atividade geográfica no Brasil, que 'sua obra será, ainda mais fecunda no dia em que um 'Comité' Nacional de Geografia puder coordená-la em espírito geográfico, pondo-se em contato com organizações análogas por intermédio da União Geográfica Internacional. Os proventos serão grandes para a ciência em geral, mas também para este belo país, tão cheio de seiva e de possibilidades de desenvolvimento.' (IBGE, 1939a, p. 9-10)

Respondendo à sugestão do Prof. de Martonne, a ABC, liderada por Everardo Backheuser, promoveu um esforço de constituição de um Comitê de Geografia como entidade privada. Porém, diversas dificuldades para congregar técnicos especializados, obter dados e colaborações, recursos financeiros etc. frustraram a iniciativa. ${ }^{37}$

De fato, em 1934, a ABC apresentou ao Ministério da Agricultura uma exposição de motivos em favor da organização de serviços geográficos, argumentando que os estudos geográficos a serem desenvolvidos com a efetiva adesão à UGI

são estudos novos, subordinados ao caráter quasi enciclopédico da Geografia moderna e para os quais o Ministério da Agricultura mantem hoje serviços técnicos nitidamente orientados para atender idênticos objetivos, que, em última análise, são os da Geografia Humana, através da Econômica. (IBGE, 1939a, p 10)

A criação do CNG como instrumento para possibilitar a adesão do Brasil à UGI significou, para Geiger (1988, p 62) um "sinal da marcha do mundo para novas fases pronunciadoras da globalização. A criação do Conselho Nacional de Geografia - CNG, em 1937, representou justamente, de um lado, a atuação da UGI no jogo hegemônico através da difusão de ideias, cultura, técnicas". Tratar-se-ia de um momento posterior à expansão política e econômica dos países industrializados para a qual contribuiu o campo geográfico.

Geiger, porém, assim como a própria Secretaria Geral do CNG, considera necessário levar em consideração condicionantes internos. Trata-se do

reconhecimento da necessidade de um setor geográfico moderno a ser justaposto às instituições tradicionais já existentes, Institutos Histórico-Geográficos, Sociedade de Geografia, e que vinham gozando de prestigio junto aos governos. Para este sentimento, contribuía a presença, já em cena, de alguns geógrafos modernos informados do que se passava no centro, autodidatas [...] Interessava dispor de um moderno setor de Geografia que, num país de dimensões continentais, exercesse, para o interior do vasto território, papel semelhante ao que a Geografia fizera para a expansão internacional dos países de centro. (GEIGER, 1988, p. 62)

\footnotetext{
${ }^{37}$ Cf. Nota 29, a respeito da participação da ABC no processo de criação de um Conselho de Geografia.
} 
Numa associação implícita entre intelectuais franceses, a Missão Universitária Francesa no Brasil também exerceu sua pressão acadêmica pela associação do Brasil à UGI. Por trás da fundação das cátedras de Geografia da USP em 1934 e da Universidade do Distrito Federal em 1935, Pierre Deffontaines ${ }^{38}$, junto com Pierre Monbeig, então ocupante da cátedra na USP, encaminhou uma carta em 1936 ao então ministro das Relações Exteriores e presidente do INE, Macedo Soares, formalizando solicitação do Instituto Histórico e Geográfico Brasileiro - IHGB, Sociedade de Geografia do Rio de Janeiro - SGRJ, AGB e ABC para criação de um órgão oficial de Geografia. A carta foi recebida com inequívoco entusiasmo e os esforços de Macedo Soares contribuíram para a instalação de um Conselho de Geografia que ia além do âmbito da já existente Seção de Estatística Territorial, voltada à cartografia, e atendia aos maiores anseios.

A própria AGB-SP, de forma independente às movimentações do núcleo carioca, em reunião em outubro de 1936, também reiterou o pedido para a criação, no âmbito do Governo Federal, de um órgão nacional de Geografia.

Paralelamente às pressões dos setores interessados, havia dentro da própria esfera governamental $^{39}$ apelo para a criação de um conselho de Geografia com vistas ao estabelecimento de um padrão mais racionalizado de informações relativas ao quadro territorial brasileiro em seus diversos aspectos e que subsidiasse tanto os programas políticoeconômicos do governo quanto os programas específicos de cada Ministério.

Numa linha de interpretação semelhante à de Geiger (1988), Penha (1993) associa a criação do CNG à contribuição que tal Conselho poderia proporcionar à expansão econômica. Para o autor, o IHGB, criado em 1838, e a SGRJ, criada em 1883, foram refratárias da expansão colonial dos países desenvolvidos e de sua sanha por informações sobre áreas para além de seus próprios territórios. Ao longo da década de 1930, teria ocorrido fenômeno análogo, em novas proporções.

O Brasil [...] colocava-se, simultaneamente, como refratário das "demandas internacionais" por informações do seu quadro territorial, e o próprio Estado brasileiro enxergava nesta proposta a possibilidade de viabilizar ações governamentais, utilizando métodos técnicos e científicos reconhecidos, para uma gestão mais racionalizada do seu território. (PENHA, 1993, p. 74)

\footnotetext{
${ }^{38}$ Mônica Machado, destaca a experiência acadêmica, a perspicácia histórica e o engajamento de Deffontaines junto aos círculos de poder na promoção de um órgão oficial de Geografia. Cf. MACHADO, 2009, p. 79-86.

${ }^{39}$ Não encontramos referências concretas às demandas por um órgão geográfico que atuasse além da produção de subsídios à estatística, mas praticamente todos os textos consultados fazem referência à necessidade de reconhecimento territorial do país, objeto sobre o qual se pretendia atuar. Macedo Soares é a exceção à regra e pode-se identificar sua atuação direta na criação de um Conselho de Geografia não restrito à atividade "meramente" cartográfica. A institucionalização de uma Geografia com uma componente acadêmica no seio do Estado não foi fortuita, mas fruto de esforço político da comunidade simpatizante neste sentido.
} 
Ainda segundo Penha (1993, p. 75) o "IHGB, através de sua ala geográfica, canalizou todos os estudos, discussões e propostas relativas a temática territorial no País." Questões quentes da agenda governamental getulista já eram tratadas há tempos pelo Instituto. ${ }^{40} \mathrm{Em}$ termos cartográficos, no entanto, suas atividades diluíam-se entre tantas outras, de agentes públicos e privados. A questão do reconhecimento, delimitação e representação cartográfica dos limites cartográficos em múltiplas escalas era um forte motivador para iniciativas geográficas, já há décadas, porém, realizado de maneira fragmentada e por vezes pouco rigorosa, inclusive pela recorrente ausência de trabalhos de campo.

No que tange ao contexto da década de 1930, é importante destacar

que tais "demandas internacionais", revestidas de caráter cientifico (para a elaboração da carta ao milionésimo através de novos padrões técnico-conceituais), tinha por base "operacional" a escala municipal. E justamente nesta escala que faltavam conhecimentos sistematizados, daí as justificativas e propostas de criação de um órgão oficial de Geografia no Brasil. (PENHA, 1993, p. 76.)

Idealizado por Teixeira de Freitas em fins de 1931, o INEC se concretizaria em 1934 na forma de INE, sem cartografia, contudo. Para compensar,

Teixeira de Freitas introduz, com o apoio natural de Juarez Távora, na estrutura da Diretoria de Estatística da Produção, do Ministério da Agricultura, uma Seção de Estatística Territorial (tendo à frente o engenheiro Christovam Leite de Castro), e que seria a matriz do futuro Conselho Brasileiro de Geografia (logo CNG). Assim, a chamada "cartografia geográfica", já estaria presente e atuante no INE, ainda que o nome Cartografia não tenha aparecido explicitamente. (SENRA, 2014, p. 4)

A Seção de Estatística Territorial - SET, da Diretoria de Estatística da Produção DEPr, constituía verdadeiro órgão dedicado à cartografia, com atribuições técnicas e acadêmicas que envolviam "coligir, coordenar e sistematizar todos os dados, quer bibliográficos, quer cartográficos, que se referissem ao território nacional, encarado sob o aspecto físico-agronômico". (BRASIL, 1934 apud GONÇALVES, 1995, p. 31$)^{41}$

Apesar da ausência da cartografia, o texto do Decreto n. 24.609, de 6 de julho de 1934, que criou o INE, abriu amplo espaço para o desenvolvimento específico da atividade

\footnotetext{
${ }^{40}$ A questão relativa à importância do IHGB e da SGRJ que, em 1941, passou a designar-se "Sociedade Brasileira de Geografia" é, sem dúvida, um dos pontos limitantes dessa dissertação. A SGRJ, por exemplo realizou os 8 primeiros Congressos de Geografia do Brasil, a partir de 1909 e contou com a participação de ministros e governadores, frente à importância dos temas debatidos. Se essas associações geográficas desempenhavam trabalho tão importante, ainda que limitado e fragmentado, porque o CNG não nasceu como desdobramento direto delas, em novas bases metodológicas, ao invés de "apenas" credenciá-las como entidades afiliadas? A necessidade de justaposição do CNG, representante da dita Geografia moderna, sobre instituições tradicionais, expressaria apenas o peso limitante da tradição de ideias consagradas? Devido à limitação deste trabalho, não realizamos nenhuma leitura no sentido de dar a devida importância a essas tradicionais entidades dedicadas à Geografia.

${ }^{41}$ BRASIL. Decreto n. 23.979, de 08 mar. 1934, art. 111, apud GONÇALVES, 1995, p. 31.
} 
cartográfica, bem como para atividades geográficas, em sentido mais amplo. Estava previsto nos itens III, IV e V do artigo 14:

III - monografias de natureza histórica cu geográfica, de caráter geral ou especializado, mas obedecendo sempre a planos sistemáticos;

IV - Os diplomas cartográficos já existentes, com referência a cada localidade, circunscrição ou região;

V - Dados de verificação cartográfica e levantamentos expeditos, a serem conseguidos com auxílio dos serviços de topografia porventura mantidos pelos Estados ou Territórios e municípios; (BRASIL, 1934) ${ }^{42}$

Além do texto do Decreto de criação do INE e da existência da SET, o texto da Convenção Nacional de Estatística, realizada logo após o Ministro das Relações Exteriores, José Carlos de Macedo Soares, assumir a presidência do Instituto, previa explicitamente, nas cláusulas $13^{\mathrm{a}}$ e $15^{\mathrm{a}}$, a organização de atividades cartográficas.

ClÁUSUla DÉCIMA TERCEIRA. Os Govêrnos Federados, pelo órgão dos serviços técnicos competentes, sejam os de engenharia em geral, sejam os especializados de geografia ou cartografia, filiados ou não ao Instituto, colaborarão nos trabalhos de cartografia geográfica necessários à estatística e centralizados, para os fins de síntese nacional, na Diretoria de Estatística da Produção, do Ministério da Agricultura, segundo planos gerais aprovados pelo Conselho Nacional de Estatística. Com êsse objetivo serão tomadas medidas, que assegurem a organização, para serem divulgadas nos anos de milésimo nove e quatro (precedentes aos censos gerais ou regionais), cartas físicas e políticas do território estadual, das quais constem a divisão municipal e, se possível, tambem a distrital, bem como as demais ordens de circunscrições administrativas e judiciárias. Aos Municípios, os mesmos serviços formularão, ainda, as sugestões convenientes e prestarão a assistência técnica necessária para que façam levantar ou revêr, com a perfeição possível, os mapas dos respectivos territórios.

$[\ldots]$

CLÁUSULA DÉCIMA QUINTA. Em complemento ao disposto na cláusula precedente, e tendo em vista que a medida é necessária não só para fins gerais da administração, mas principalmente para classificar a população do país em "urbana" e "rural", com os respectivos coeficientes de densidade, as Altas Partes Federadas propõem-se, como objetivo comum, a ser conseguido pelas medidas que a organização de cada Estado permitir, que todas as municipalidades fixem ainda êste ano, determinandolhe os limites e a área, o "quadro urbano" da cidade ou vila séde do município, ficando tambem assentado que êsse quadro só possa ser modificado por ato do respectivo govêrno, no qual venham referidos os novos limites e o acréscimo de área resultante da alteração. (INE, 1936, p. 20/22) 43 $^{4}$

O próprio texto do Decreto n. 1200 de, 17 de novembro de 1936, que regulou a instalação e funcionamento do Conselho Nacional de Estatística, previa em seu $4^{\circ}$ parágrafo do $2^{\circ}$ artigo:

Os serviços geographicos officiaes, bem assim os de instituições privadas, de reconhecida idoneidade, poderão tambem filiar-se ao Instituto, isolada ou collectivamente, na fórma do acto especial que o autorize e segundo as bases que o

\footnotetext{
42 BRASIL. Decreto n. 24.609, de 6 jul, 1934. Disponível em: <http://www2.camara.leg.br/legin/fed/decret/19301939/decreto-24609-6-julho-1934-515214-publicacaooriginal-1-pe.html>. Acesso em: 12 jul. 2015.

${ }^{43}$ INE. Convenção Nacional de Estatística. Rio de Janeiro: Ministério do Trabalho, Indústria e Commercio, Departamento de Estatística e Publicidade, 1936. 32p. Disponível em: <http://biblioteca.ibge.gov.br/> Acesso em 29 fev. 2016.
} 
Conselho Nacional de Estatistica approvar para o estabelecimento da cooperação entre os alludidos serviços e os de estatistica. (BRASIL, 1936) ${ }^{44}$

A Assembleia Geral do CNE rapidamente reconheceu a legitimidade da filiação das entidades geográficas ao sistema interadministrativo integrado ao INE.

Dessa forma, firmou-se uma aliança no Instituto, conjugando o conhecimento da terra com o da atividade humana, em benefício da estatística, cujo aperfeiçoamento carecia de elementos geográficos, para interpretação adequada dos valores. (GONÇALVES, 1995, p. 31)

Paralelamente aos textos que davam crescente legalidade à necessidade por atividades explicitamente cartográficas, a necessidade prática pressionou a alta cúpula do INE a dar maior atenção ao problema. Desconhecimento do quadro territorial em detalhes, delimitação imprecisa dos limites político-administrativos e imprecisão dos documentos cartográficos fornecidos pelas variadas unidades político-administrativas atuavam, conjuntamente, como um funil à capacidade de fornecimento de informações estatísticas por parte do INE, que se via cada vez mais impossibilitado de estabelecer critérios racionalizados para o tratamento das informações. (PENHA, 1993, p. 78)

\footnotetext{
${ }^{44}$ BRASIL. Decreto n. 1200, de 17 nov. 1936. Disponível em: <http://www2.camara.leg.br/legin/fed/decret/19301939/decreto-1200-17-novembro-1936-458730-publicacaooriginal-1-pe.html>. Acesso em: 12 jul. 2015.
} 


\section{CAPÍTULO 2}

\section{CONTRIBUIÇÕES DO CNG A PARTIR DA REVISTA BRASILEIRA DE GEOGRAFIA}

Geografia - "instrumento da administração, da guerra e do capital.” (ZARUR, 1944, p. 317) (5 $^{45}$

No capítulo anterior, apresentamos de maneira introdutória algumas passagens significativas do desenvolvimento da estatística territorial brasileira que, em termos nacionais, se confunde com o desenvolvimento da própria estatística, em termos científicos. Vale lembrar que, embora remonte ao final do século XVII, tal ciência apenas ganha maior aplicabilidade junto à administração pública, no contexto europeu, a partir do desenvolvimento da demografia e das técnicas de amostragem na Inglaterra. Apenas no alvorecer do século XIX as principais potências europeias iniciariam a prática censitária.

Refratária do desenvolvimento científico estrangeiro, não havia, de todo modo, qualquer demanda por estatísticas territoriais no Brasil antes da fuga da Coroa portuguesa para o Rio de Janeiro. A Coroa e, em seguida, o Império se defrontariam com as necessidades da administração pública sobre um território profundamente fragmentado em termos econômicos, sociais e políticos, quando não um território simplesmente desconhecido.

O excesso de demandas sobre um Governo sem conhecimento processual em termos administrativos, somado aos interesses agroexportadores da elite escravocrata nacional resultam em uma prolongada ausência de iniciativas concretas voltadas ao desenvolvimento do aparelho estatístico.

Finalmente, em 1871 a DGE é criada e, em 1872, ocorre o primeiro recenseamento da história do Brasil e o único do Império. A Primeira República herda um aparelho estatístico e realiza seu primeiro recenseamento, em 1890. Sua publicação completa data apenas de 1900, ano do terceiro recenseamento geral do país, que ficaria marcado por sua duvidosa qualidade.

Em 1907 a DGE passa por remodelação, durante a breve passagem de Bulhões Carvalho. Cria-se a CSE, cuja função rapidamente se perde. O retorno do demógrafo sanitarista à presidência da Diretoria em 1915, onde permaneceu até 1931, foi marcado por iniciativas seminais e tecnicamente qualificadas. Apesar disso, porém, a Diretoria é empurrada para diversos ministérios, muda de nome, experimenta cortes sucessivos e, incapaz

\footnotetext{
45 "A Geografia utilitária fêz milagres nesta guerra. Só quem acompanhou, de perto, os trabalhos do batalhão de geógrafos mobilizados pelo Govêrno norte-americano, poderá saber da eficiência e da grandeza da contribuição que trouxe o Geógrafo à causa da guerra moderna: desde o mapa até a análise, quilômetro por quilômetro, das regiões invadidas." (ZARUR, 1944, p. 316)
} 
de fornecer dados satisfatórios, vê seu prestígio reduzir-se, estimulando novos cortes em sua estrutura. Em 1920, ocorre o quarto recenseamento do país. O término do mesmo basta para uma nova crise da Diretoria que, aos solavancos, sobrevive até ser reformulada, em 1931. O DNE (1931), ligado ao MTIC, incorporou a DGE (1871) do extinto MAIC e a DEC, do MF, sem, no entanto, substitui-los. O novo Governo, munido de um projeto nacional, percebe a importância dos números para alcançar seus objetivos, quaisquer que fossem estes.

Para a construção, mais do que para o conhecimento, do país que se queria, Teixeira de Freitas, consagrado por seu trabalho Minas Gerias ao longo da década de 1920, elevaria as estatísticas nacionais a um novo e definitivo patamar. Criado o INE em 1934, apenas em 1936 toma posse seu primeiro presidente, o prestigiado Embaixador Macedo Soares.

Paralelamente ao processo de instalação do INE, desde 1931 cresce a pressão internacional para a adesão do Brasil à UGI, pressão essa alimentada pela visita de Emmanuel de Martonne ao país, em 1933.

O presente capítulo, além de descrever o processo de constituição e instalação do CNG, que daria origem ao IBGE, faz uma análise de materiais selecionados publicados na Revista Brasileira de Geografia - RBG, com o objetivo de compreender melhor a importância da Geografia realizada junto ao CNG na organização do campo e do pensamento geográfíco brasileiro.

\subsection{CONSTITUIÇÃO E INSTALAÇÃO DO CNG}

Logo após a Convenção Nacional de Estatística, que segundo Gonçalves (1995), pode ser definida como a espinha dorsal do sistema estatístico brasileiro, junto às resoluções convencionadas, foi encaminhada uma carta assinada por Pierre Deffontaines apelando pela adesão do Brasil à UGI. Tratava-se de uma particular oportunidade para ABC, IHGB, SGRJ, de um lado, e os professores Pierre Monbeig, Pierre Deffontaines e AGB, do outro, articularem junto à José Carlos de Macedo Soares a constituição de um Conselho de Geografia ligado à Seção de Estatística Territorial do Ministério da Agricultura.

Também o próprio CNE, na Resolução n. 18 da Assembleia Geral de 30 de dezembro de 1936, que fixou as condições de filiação, ao Instituto, das instituições e serviços geográficos, levou em consideração a organização, em vias de concretização, do CNG tendo como base a SET: 
considerando ainda que está em via de organização o Conselho Brasileiro de Geografia como órgão nuclear de um sistema coordenador das Instituições geográficas nacionais, apoiado, para o trabalho executivo, na secção de estatística territorial, da Diretoria de Estatística da Produção, uma das repartições centrais do sistema federal do Instituto (IBGE, 1943, p. 212)

Mas também aqui é necessário destacar a grande distância entre a proposta de ciência geográfica presente nos congressos internacionais de Geografia, como o de Paris de 1931, e a atividade cartográfica realizada sob a brigada da SET.

O texto elaborado pela Secretaria Geral do CNG, presente no primeiro volume da RBG (IBGE, 1939a, p. 10), faz referência à carta da ABC enviada ao Ministério da Agricultura, em 1934, na tentativa de articular um conselho de Geografia junto à SET. A passagem afirma que a Academia revelava "conhecimento das finalidades e da organização dos serviços geográficos e estatísticos afetos ao Ministério, sobretudo os da sua Diretoria de Estatística da Produção". Segundo o próprio Macedo Soares, a SET centralizava "os serviços cartográficos indispensáveis à estatística brasileira.”

Seus resultados avultavam rapidamente, e apreciados no conjunto dos serviços da Secção onde a geografia econômica é preocupação primacial, davam claramente a idéia de que aquele órgão estava naturalmente indicado para centro nuclear do sistema geral, tão urgentemente necessário em nossa organização administrativa, de coordenação das atividades geográficas brasileiras. (SOARES, 1939, p. 100)

Embora tivesse, de fato, conhecimento das atividades realizadas junto à DEPr, a ABC parece ter desconsiderado a natureza das atividades realizadas junto àquela Diretoria no intento de concretizar seu objetivo. Não se tratava, de fato, da atividade geográfica segundo os preceitos da ciência moderna praticada na França, mas "apenas" da dimensão cartográfica tradicionalmente relacionada à disciplina - que, nesta Diretoria, restringia-se à necessária para a execução das estatísticas. Uma análise comparativa das atividades da Diretoria e dos trabalhos publicados na RBG revelam grande diferença qualitativa. Assim, a carta assinada pela $\mathrm{ABC}$ parece desconsiderar o que lhe convém, ao passo que o CNG se refere à atividade "geográfica" da DEPr de modo a monumentalizar a história do Conselho segundo seu ponto de vista.

Portanto, havia dois entendimentos sobre a natureza da prática geográfica em questão. Uma subordinada, técnica, processual, atrelada à atividade estatística, constante dos trabalhos em cartografia e geodésia. Proposta bem diferente sobrevém do "caráter quase enciclopédico da geografia moderna", da interpretação sobre o quadro territorial baseada em novas técnicas de investigação, da exigência de trabalho empírico e de rigor metodológico, alinhado com a literatura internacional. Sem dúvida, a pressão de órgãos como a UGI e do governo francês, através do envio de missões culturais, visavam integrar o Brasil no esforço de classificação enciclopédica da geografie universelle, em seu objetivo de reunir e integrar o conhecimento das diversas regiões naturais do globo. (CAMARGO, 2009, p. 219) 
O embaixador e Presidente do INE, porém, valendo-se de sua autoridade e prestígio, foi muito além da Convenção Nacional de Estatística, cuja intenção era possibilitar um "acordo interadministrativo entre a União e os estados, territórios, municípios ou entidades privadas, visando a colocar, gradativamente, sob a influência unificadora do Instituto, a totalidade dos esforços e recursos que os poderes públicos e a iniciativa particular já estivessem dedicando ou viessem a dedicar a fins da estatística nacional.” (GONÇALVES, 1995, p. 28)

Por considerar conveniente a participação do Brasil nos empreendimentos científicos internacionais, Macedo Soares apresentou a proposta de criação de um Conselho Brasileiro de Geografia ao Presidente da República, que prontamente a aprovou. Convocou, então, no Itamaraty, as mais altas personalidades representativas da cultura geográfica brasileira para a elaboração de um projeto de criação do Conselho.

O trabalho, debatido em cinco reuniões, no período de 26 de outubro a 18 de novembro de 1936, originou o Decreto $\mathrm{n}^{\mathrm{o}} 1.527$, de 24.03.1937, instituindo o Conselho Brasileiro de Geografia, incorporado ao Instituto Nacional de Estatística, e autorizando sua adesão à União Geográfica Internacional. (GONÇALVES, 1995, p. 32)

Para Camargo (2009, p. 222), a empreitada de Macedo Soares "não era impune ou inocente. Ela se compatibilizava plenamente com sua trajetória de homem de ação e de letras, articulando espaços caros à sua autoridade política e intelectual, em benefício de sua projeção pessoal." O autor insiste no fato de que foi Macedo Soares "o principal nome no movimento decisivo que levou à criação do CNG”. Se por um lado era importante que o Presidente do INE tivesse prestígio e influência política, por outro, revelou-se homem de impressionante capacidade técnica, fruto de sua experiência acumulada em países estrangeiros. Uniu domínio político e técnico e, ao longo de 15 anos de presidência do Instituto, consolidou e deu regularidade à atividade estatística. Mas foi além desta e dificilmente um mero burocrata teria contribuído tanto para a consolidação da ciência geográfica não restrita à cartografia junto ao INE.

A revisão biográfica de Macedo Soares é reveladora de suas ligações acadêmicas junto à História e à Geografia. Homem de grande erudição, autor de trabalhos ainda hoje célebres no tocante à educação, à questão territorial e às fronteiras nacionais, Soares era sóciocorrespondente do IHGB desde 1921, instituição da qual tornou-se presidente perpétuo a partir de 1940. A partir de meados da década de 1930, acumulou cargos simultâneos na ABC, IHGB, SGRJ e Instituto Pan-Americano de Geografia e História - IPANGH. ${ }^{46}$ Dessa maneira, pôde fomentar um espírito de simbiose e efetiva complementaridade entre as diversas

\footnotetext{
${ }^{46}$ Cf. CAMARgo, Alexandre de P. R. Um homem de fronteiras: ação e criação de José Carlos de Macedo Soares. (Cap. 17). In SENRA, Nelson de C. História das estatísticas brasileiras, v. 3: Estatísticas organizadas (c.1936c.1972). Rio de Janeiro: IBGE-CDD, 2006, p. 539-593.
} 
organizações filiadas ao $\mathrm{CNG}$, ao mesmo tempo em que estabelecia e disseminava as práticas da moderna Geografia e do novo ensino geográfico, nas redes básica e superior. Seu largo trânsito acadêmico é fruto, em parte, de sua própria filiação acadêmica e pelo prestígio acumulado em período anterior à sua presidência no IBGE, mas também do reconhecimento pelos serviços prestados à criação do CNG.

A instalação do CBG ocorreu no salão de conferências do Palácio Itamaraty, em 14 de julho de 1937, dia também da abertura dos trabalhos de sua Assembleia Geral. Uma das primeiras providencias da Assembleia foi aprovar uma Resolução que recomendava, como empreendimento fundamental do CBG, a atualização da carta geográfica do Brasil ao milionésimo, determinando a coleta imediata dos elementos cartográficos e demais documentos referentes ao território nacional, necessários ao seu preparo.

A incorporação do Conselho Brasileiro de Geografia ao Instituto Nacional de
Estatística, em atividades paralelas ao Conselho Nacional de Estatística, gerou a
necessidade de modificar seu nome, de modo a evidenciar integralmente as
atribuições que lhe eram peculiares. Passou, assim, a denominação de Instituto
Brasileiro de Geografia e Estatística - IBGE -, conforme Decreto $\mathrm{n}^{\circ} 218$, de
26.01 .1938 , que também alterou, por conveniência de uniformidade na designação
dos órgãos deliberativos, o nome de Conselho Brasileiro de Geografia para
Conselho Nacional de Geografia. (GoNÇALVES, 1995, p. 32)

Vale ressaltar a impressão de que a constituição do CNG foi o resultado óbvio de um Estado burguês periférico em processo de aparelhamento institucional e modernização burocrática, com a singularidade de possuir um imenso território ainda largamente desconhecido sobre o qual pretendia exercer sua autoridade. Esta sensação é a primeira e a mais forte que temos, ao lermos textos históricos relativos à constituição do Conselho. $\mathrm{O}$ fato, porém, é que a então pequena comunidade de geógrafos agiu conscientemente no sentido de garantir para si, ou ao menos participar diretamente, do campo de atuação ligado à cartografia.

Conquanto fosse grande a necessidade de o Estado reconhecer suas potencialidades paisagísticas, era ainda maior o interesse internacional nesse sentido. Este, revestido de caráter científico na forma de encontros, palestras, congressos internacionais, etc., foram um importante aliado da comunidade geográfica brasileira ${ }^{47}$ no sentido de vencer a resistência de expressivas alas contrárias à instalação de um oneroso serviço de reconhecimento territorial, em parte mesmo por desconhecimento da importância que um tal serviço poderia vir a desempenhar.

\footnotetext{
${ }^{47}$ É improcedente falar-se em "comunidade geográfica brasileira" no período considerado. Como já indicado, porém, havia uma prática geográfica sendo realizada em território nacional e já existia, ao menos, uma comunidade de simpatizantes ao labor que se entendia geográfico. A instituição da chamada Geografia moderna dava seus primeiros passos justamente com a instituição do CNG e dos núcleos acadêmicos em São Paulo e Rio de Janeiro.
} 
Nesse sentido, embora os esforços contrários à formação de um serviço geográfíco tenham levado à restrição da Geografia à dimensão estritamente cartográfica, foi esta dimensão que permitiu aos geógrafos organizarem-se em prol de maior campo de trabalho. A existência de um campo de pesquisas geográficas nunca esteve, por si próprio, garantido. $\mathrm{O}$ processo de consolidação do CNG, bem como os trabalhos inicialmente assumidos por este Conselho, em grande parte registrados na Revista Brasileira de Geografia, são reveladores nesse sentido.

O Decreto n. 1.527, de 24 de março de 1937, que em seu Artigo $1^{\circ}$, instituiu o então Conselho Brasileiro de Geografia, decretou que este conselho seria o responsável pelo amplo trabalho de

reunir e coordenar, com a colaboração do Ministério da Educação e Saúde, os estudos sôbre a Geografia do Brasil e a promover a articulação dos Serviços oficiais (federais, estaduais e municipais), instituições particulares e dos profissionais, que se ocupem de Geografia do Brasil no sentido de ativar e sistematizado do território pátrio. (BRASIL, 1937) $)^{48}$

Apesar da extensão do trabalho previsto, porém, o parágrafo $2^{\circ}$ do artigo $2^{\circ}$ do decreto determinou:

\begin{abstract}
A organização e superintendência dos serviços da Secretaria Geral do Conselho competirão á Secção de Estatística da Produção do Ministério da Agricultura, cujo assistente-chefe será o Secretário Geral do Conselho, membro nato do Diretório. (BRASIL, 1937)
\end{abstract}

Por meio desta determinação, estavam assegurados os esforços dos simpatizantes da Geografia em transformar a então manobra de Teixeira de Freitas para garantir a presença da cartografia no seio estatal, em repartição pública voltada para a atuação privilegiada de geógrafos. Tendo em vista, contudo, o acertado esforço de Teixeira de Freitas em articular a estatística à cartografia, a intensidade do programa estabelecido para a Seção de Estatística Territorial da Diretoria de Estatística da Produção gerou rápido desenvolvimento, destoante da limitada posição de dependência ministerial de segunda ordem.

Frente a este fato e do que se pode depreender da Resolução n. 28, de 19 de julho de 1938 da Secretaria Geral do CNG, a comunidade interessada no fortalecimento do campo geográfico no Brasil agiu concretamente neste sentido. A referida Resolução, no que concerne às justificativas prévias dadas às resoluções tomadas, dentre outros pontos, assim declara:

\footnotetext{
${ }^{48}$ BRASIL. Decreto n. 1.527, de 24 mar. 1937. Disponível em: <http://www2.camara.leg.br/legin/fed/decret/19301939/decreto-1527-24-marco-1937-449842-republicacao-74463-pe.html> Acesso em 13 jan. 2016. Observar que este decreto, em suas justificativas, delimita, especificamente, o interesse nacional sobre a Geografia do Brasil, embora a ambiguidade do termo não torne claro se se fala do objeto de estudo ou do campo de atuação, em referência a todas as atividades de cunho geográfico realizadas em território nacional.
} 
considerando que a Secretaria do Conselho precisa ser convenientemente aparelhada para poder empreender essa desejada coordenação, porquanto a Secção de Estatística Territorial da Diretoria de Estatística da Produção do Ministério da Agricultura não dispõe da indispensável autonomia administrativa nem dos recursos permanentes suficientes;

$[\ldots]$

considerando a necessidade urgente do Conselho em promover as iniciativas governamentais que permitam a conveniente criação dos serviços indispensáveis à constituição eficiente do sistema geográfico do Instituto, de modo que êste sistema, quanto antes, se equipare em sua organização, ao sistema estatístico; considerando que, por parte do Govêrno Federal, é possível e fácil crear, imediatamente, um indispensável departamento autônomo de coordenação geográfica, mediante ampliação da mencionada Secção especializada com os elementos próprios do Conselho, sob um regime administrativo conveniente; [...] (IBGE, 1943b, p. 215-216. Grifos nossos.)

Imbuída do espírito de autonomia, a Resolução assim resolve, dentre outros aspectos:

Art. $1^{\circ}$ A Presidência do Instituto providenciará, quanto antes, sôbre a expedição de um decreto-lei federal autorizando o Instituto Brasileiro de Geografia e Estatística a fazer um acôrdo com o Ministério da Agricultura, no sentido de ser transferida à responsabilidade administrativa do Instituto a Secção de Estatística Territorial da Diretoria de Estatística da Produção.

Parágrafo único. - Nêsse decreto deverá também ser dada autorização ao Instituto para instalar o "Departamento Central de Coordenação Geográfica", mediante a conveniente ampliação da referida Secção, conforme as diretrizes fixadas pela presente Resolução.

$[\ldots]$

Art. $5^{\circ} \mathrm{O}$ Departamento terá por finalidade reunir e aproveitar os elementos fornecidos pelos órgãos do Conselho e demais trabalhos referentes ao território brasileiro, para a elaboração das expressões cartográficas e estudos geográficos que forem da alçada da Secretaria Geral do Conselho. (IBGE, 1943b, p. 216.)

É válido mencionar que a já referida Resolução n. 18, de 30 de dezembro de 1936, da Assembleia geral do CNE, também previa total autonomia aos serviços e institutos geográficos que se filiariam ao INE.

Art. $3^{\circ}$ Ao sistema filiando [sic] ficará assegurada, no seio do Instituto, situação de completa autonomia, rigorosamente equivalente à do sistema do serviços estatísticos. (IBGE, 1943a, p. 212)

O desdobramento direto desta Resolução n. 28 da Secretaria Geral do CNG foi o Decreto-Lei n. 782, de 13 de outubro de 1938, cuja ementa resume:

Transforma provisoriamente a Secção de Estatística Territorial, da Diretoria de Estatística da Produção, no Serviço de Coordenação Geográfica, com as funções de secretaria geral do Conselho Nacional de Geografia e órgão dos serviços geográficos da Comissão Censitária Nacional. (BRASIL, 1938 apud IBGE, 1939f, p. 141)

Considerando o Governo a posição de órgão técnico executivo central do Conselho Nacional de Geografia, incumbido dos trabalhos de natureza geográfica, cabendo-lhe, consequentemente, importantes encargos de natureza geográfica na fase preparatória do Recenseamento Geral da República de 1940, transformou a referida seção em Serviço de 
Coordenação Geográfica - SCG. (GonÇALVES, 1995, p. 32) O apelo em caráter de urgência por parte da Comissão Censitária Nacional para elevar o SCG, "à categoria de 'órgão central' incumbido da coordenação dos serviços geográficos do Instituto Brasileiro de Geografia e Estatística e, como tal, responsável pelos trabalhos censitários de caráter geográfico" (BRASIL, 1938 apud IBGE, 1939f, p. 142), fortaleceu a posição dos colaboradores do CNG em torná-lo uma repartição autônoma no seio de uma entidade autárquica.

Com a Resolução n. 31, de 8 de Fevereiro de 1939, o Diretório Central do Conselho baixou o Regulamento do Serviço de Coordenação Geográfica, que solenemente se instalou, como repartição autônoma, diretamente subordinada ao Instituto Brasileiro de Geografia e Estatística, em 15 de Março de 1939. (CASTRO, 1943, p. 227)

Por força do Decreto-Lei n. 1360, de 20 de junho de 1939, o SCG passou a ser denominado Serviço de Geografia e Estatística Fisiográfica - SCGF, dentro de um plano de padronização das Repartições Centrais do IBGE. O SCGF preservava sua posição de órgão central executivo do CNG, mas, assim como outros Serviços de Estatística, subordinados a diferentes ministérios, previa o decreto que ao fim do Recenseamento Geral de 1940 o SCGF se subordinasse à jurisdição do Ministério de Viação e Obras Públicas, como órgão de coordenação estatística do referido Ministério, além das estatísticas territoriais.

Em resposta ao previsto no Decreto, a Secretaria Geral do CNG aprovou a Resolução n. 127, de 9 de julho de 1942, que a partir de consulta prévia do Conselho Nacional de Estatística e do Ministério da Viação e Obras Públicas, propõe:

uma organização adequada que a dote de aparelhamento eficaz para a realização de levantamentos territoriais, na proporção conveniente aos objetivos do Conselho e à atuação ampla, intensa, de grande efeito coordenador e cooperador, que deve caber a uma repartição geográfica federal. (IBGE, 1944b, p. 968)

Além da sugestão de criação de uma Serviço de Estatística dos Transportes, Comunicações e Obras Públicas, propõe também, como repartição central do CNG, dele administrativa e tecnicamente dependente

um serviço nacional de Geografia, devidamente aparelhado com recursos para levantamentos territoriais, sobretudo com a utilização da técnica aerofotogramétrica, devidamente adaptada às peculiaridades brasileiras. (IBGE, 1944b, p. 968)

Tomando para si o trabalho cartográfico como campo de atuação privilegiado para geógrafos, a comunidade geográfica em formação buscou ressaltar a importância da técnica aerofotogramétrica, em plena ascensão naquele período, como forma de fortalecer sua posição. Esta técnica, aliás, é citada no texto da Convenção Nacional de Estatística como meio de se possibilitar a representação cartográfica dos estados brasileiros. 
Cláusula Trigésima Segunda. As Altas Partes Compactuantes convêm em formular os seguintes votos:

$[\ldots]$

j) - para que os Govêrnos Estaduais, em necessária continuidade de ação e recorrendo aos recursos da aerofotogrametria, providenciem quanto antes para a rápida, exata e suficiente representação cartográfica dos respectivos territórios. (INE, 1936, p. 32)

Novamente o Governo Federal demonstrou-se favorável às aspirações do Conselho e atendou plenamente às solicitações da Assembleia Geral do CNG, com a publicação do Decreto-Lei 6828, de 25 de agosto de 1944, segundo o qual:

Art. $1^{\circ}$ - Fica criado o Serviço de Geografia e Cartografia (S. G. C.), no Instituto Brasileiro de Geografia e Estatística e destinado a funcionar como órgão executivo central do Conselho Nacional de Geografia.

Art. $2^{\circ}-$ O Serviço de Geografia e Cartografia terá como finalidade a execução de trabalhos geográficos, cartográficos e fotogramétricos que lhe forem determinados pelo Conselho Nacional de Geografia. (IBGE, 1944a, p. 782)

O decreto presidencial levou em consideração não apenas as resoluções tomadas pela Secretaria Geral do CNG, mas também as recomendações da II Reunião Pan-americana de Consulta sobre Geografia e Cartografia, promovida pelo Instituto Pan-americano de Geografia e História e pelo IBGE, ocorrida no mês em que o decreto foi publicado, na qual se reuniu representantes de praticamente todos os países do continente americano em torno de questões relativas à geografia e, especialmente, à cartografia.

Em termos quantitativos, a II Reunião aprovou um expressivo número de disposições, relacionadas à cartografia e à geografia em escala continental. Das disposições aprovadas, nove foram sobre assuntos gerais; outras nove sobre geodésia; dez sobre mapas topográficos; outras dez sobre cartas aeronáuticas; sete sobre cartas hidrográficas; cinco sobre terminologias geográficas e convenções cartográficas; e, por fim, onze sobre geografia aplicada. Já sob o ponto de vista qualitativo, "as deliberações aprovadas denunciam um sentido geral, que se pode definir nas três pronunciadas tendências - a modernização dos métodos, a intensificação dos trabalhos e a uniformização internacional dos planos.” (IBGE, 1944c, p. 375)

De fato, de maneira geral, estas Reuniões - com especial dedicação por parte dos Estados Unidos na promoção dos encontros e no oferecimento de técnicos, instrumentos e cursos de extensão - estavam imbuídas de uma preocupação de fundo econômico, com vistas já ao fim da II Guerra Mundial. Com o aperfeiçoamento da fotogrametria, recurso importante no progresso da cartografia militar, empreendimentos "no campo das explorações do subsolo, das culturas em grande escala, do povoamento ou dos programas de transporte" (ABREU, 
1943, p. 3) poderiam também se beneficiar das novas e aperfeiçoadas técnicas voltadas ao levantamento cartográfico. ${ }^{49}$

Frente ao exposto, pode-se afirmar que, em um de seus aspectos profundos, a cartografia foi o campo de atuação profissional que garantiu à ciência geográfica, em um apelo à tradição, engajar-se junto às preocupações estatais, garantindo para si seu próprio campo de trabalho. Assim, a medida provisória em torno dos serviços geográficos visando ao Censo de 1940 tornou-se permanente, garantindo ao CNG e aos geógrafos brasileiros, ao menos por um período, um robusto e autônomo aparelho de trabalho e pesquisa.

Deste apreciável amálgama, ver-se-á adiante que a cartografia, ao possibilitar que os geógrafos trabalhassem, a despeito do viés excessivamente voltado à gestão econômica do território, permitiu o desenvolvimento do instrumental epistemológico da ciência geográfica e, como linguagem, está presente de maneira muito mais profunda nas produções intelectuais dos geógrafos do que pode parecer à primeira vista.

\subsection{A RBG - CONSIDERAÇÕES METODOLÓGICAS}

Segundo Geiger, até os anos de 1970 “o IBGE foi o principal centro de adoção e difusão de todas as novas ideias e métodos surgidos na geografia mundial. Foi a porta de entrada das mais variadas correntes" no Brasil (GEIGER, 1988, p. 66), incluindo a adoção da Geografia Quantitativa, em consonância com as novas demandas nacionais, em fins da década de 1960.

Embora diversos relatórios e publicações temáticas especiais e técnicas tenham sido publicadas de maneira independente, a Revista Brasileira de Geografia, por sua continuidade, volume de publicações e importância acadêmica dentro do período considerado é capaz de, ao menos, espelhar as linhas de pesquisa e trabalho de cunho geográfico mais relevantes que se desenvolveram no seio do IBGE.

Surpreendentemente, não encontramos nenhum trabalho significativo dedicado a analisar a natureza do saber geográfico publicado pela RBG, em seu conjunto. Considerações a este respeito restringem-se a afirmações genéricas quanto à importância da Geografia, sem

\footnotetext{
${ }^{49}$ Cf. também: IBGE. II Reunião Pan-americana de Consulta sobre Geografia e Cartografia. Boletim Geográfico, v. 3, n. 31, 1945a, p. 943-946. (Resenhas e Opiniões.) Para uma descrição detalhada sobre o encontro, cf.: IBGE. II Reunião Pan-americana de Consulta sobre Geografia e Cartografia. Revista Brasileira de Geografia, v. 6, n. 3, 1944d, p. 404-429. (Noticiário.)
} 
análises específicas. ${ }^{50}$ Não se pode deixar de fazer referências à dissertação de mestrado de Simas (2008) e ao artigo de Salvi (2015).

Intitulada A Revista Brasileira de Geografia em foco: um panorama político-territorial do Brasil - 1939 a 1945, orientada por Mônica Sampaio Machado cuja tese de doutorado é referência básica em nossa pesquisa, e tendo como membro da banca examinadora Eli Alves Penha, autor de trabalho fundamental no âmbito da historiografia geográfica brasileira, a dissertação de Adriana de Melo Simas (UERJ, 2008) infelizmente não fez jus ao potencial indicado no título e se restringiu ao resumo, sem análise, de alguns importantes artigos publicados pela RBG. Fortemente vinculado ao tema do Capítulo 2 do presente texto, a dissertação de Simas ao menos colaborou com a identificação destes trabalhos referenciais publicados pela RBG.

Já o artigo intitulado Tradições de pesquisa geográfica compreendidas pelo viés da Revista Brasileira de Geografia - 1939 a 1959, publicado nos Anais do XI Enanpege (2015), sob autoria de Rosana Figueiredo Salvi, possivelmente por suas limitações quanto à extensão, praticamente não contribuiu com nossa pesquisa, já que sua proposta geral - avaliar o pensamento geográfico presente nas publicações da RBG a partir de um modelo específico de avaliação científica - não revelou aspectos eventualmente ainda não percebidos da Geografia associada às ambições estatais.

Por fim, não localizamos pesquisas no âmbito da historiografia geográfica que versam sobre materiais potencialmente importantes ligados ao escopo da Geografia publicados de forma avulsa pelo IBGE, ou seja, fora do âmbito da RBG ou do Boletim Geográfico. As referências a estes materiais restringem-se à sinalização da existência, sem análise específica. Este fato dificultou nossa análise por fontes secundárias e reforçou nossa dúvida quanto à representatividade, em termos de importância e volume de publicação, de trabalhos de natureza mais técnica, como os cartográficos, publicados nas páginas da Revista. Um limitante a este respeito é que, embora tenhamos conseguido identificar algumas dessas publicações avulsas publicadas pelo CNG, estas encontram-se na Biblioteca Central do IBGE, no Rio de Janeiro. ${ }^{51}$ Não sendo a localização desses materiais um impeditivo à pesquisa, de

\footnotetext{
${ }^{50}$ Uma das exceções é a dissertação de Prevé (1989). Seu trabalho, aliás, versa sobre as páginas do Boletim Geográfico, cuja publicação complementar à RBG também carece de melhor análise de conteúdo, tanto em si mesmo, como de maneira a complementar o entendimento do oficioso pensamento geográfico do IBGE. Cf. Prevé, Orlandina da Silva Damian. A participação do Boletim Geográfico do IBGE na produção da metodologia do ensino da Geografia. Campinas, 1989, 339 p. Dissertação (Mestrado) - Faculdade de Educação, Universidade Estadual de Campinas.

${ }^{51} \mathrm{O}$ importante ensaio sobre divisão regional do Brasil sob autoria de Fábio de Macedo Soares Guimarães, por exemplo, foi publicado tanto na RBG (v. 3, n. 2, 1941, p. 318-373) quanto em volume independente e está
} 
todo modo, o universo de trabalho que se abre com a perspectiva de se investigar essas publicações também está amplamente fora dos limites da presente pesquisa. Um aprofundamento quanto aos trabalhos realizados pelo $\mathrm{CNG}$, contudo, não poderiam deixar de fazer referência a estas publicações independentes.

\subsubsection{Periodicidade e "Índice Geral"}

A Revista Brasileira de Geografia foi publicada de maneira ininterrupta entre 1939 e 1996, totalizando 219 números. Em 2005 ensaiou-se uma retomada da publicação, com dois novos números, mas o volume final veio à lume no ano seguinte, em 2006, em publicação comemorativa onde se publicou alguns artigos clássicos da Revista. No total, foram 222 publicações, reunindo 238 números, divididos em 60 volumes. ${ }^{52}$

Até 1996 a publicação manteve a periodicidade trimestral, cada volume contando com quatro números. As exceções foram pontuais: em 1978, 1979, 1983 e 1984 um dos volumes publicou dois números de uma só vez; em 1985, os quatro números foram publicados em dois volumes; em 1988, além dos tradicionais quatro números do volume, foram publicados dois números especiais, em comemoração aos 50 anos da Revista; e em 1993, 1994 e 1996, um único volume condensou os quatro números da publicação. Em 2005, a Revista passou a ser de periodicidade semestral, porém, deixou de ser publicada no ano seguinte, ano em que condensou os dois planejados números em um único volume.

A análise a seguir, referente aos aspectos gerais da Revista, baseou-se na edição comemorativa de 45 anos de 1985, volume 47, números 1/2, na qual a Biblioteca Central do IBGE publicou fac-símiles do "Sumário" de todos os 180 números publicados entre 1939 e

disponível para download no site do IBGE: <http://biblioteca.ibge.gov.br/visualizacao/livros/liv13971.pdf>. Acesso em: 13 jul. 2015. A digitalização de materiais como este, contudo, ainda é pontual.

Outro exemplo é a publicação, a partir de uma Resolução da Assembleia Geral do CNE, de "um resumo do estudo sôbre os problemas de base do Brasil, elaborado em 1941 pela Secretaria-Geral do Instituto e então encaminhado pelo Presidente da entidade à consideração do Govêrno" (IBGE, 1945, p. 5) que, até 1958, ganharia mais quatro edições. A publicação, chamada também de "Ideário Cívico" do IBGE, pode ser considerada, lato sensu, o primeiro plano de desenvolvimento nacional. Cf. IBGE. Problemas de base no Brasil. Rio de Janeiro: Serv. Gráf. do IBGE, 1945. Disponível em: <http://biblioteca.ibge.gov.br/visualizacao/livros/liv14069.pdf>. Acesso em: 26 ago. 2014.

Outros exemplos poderiam ser dados, dentre eles o texto clássico de Jorge Zarur, A bacia do médio São Francisco: uma análise regional (IBGE-CNG, 1946), cuja concepção anglo-saxônica de região e proposta de ciência geográfica em parâmetros mais dedutivos e como "instrumento da administração, da guerra e do capital" (ZARUR, 1944, p. 317) puderam ser plenamente aplicadas.

52 No primeiro semestre de 2016, a publicação da RBG foi retomada, em formato on-line. O lançamento do volume 61 da Revista coincidiu com a comemoração de 80 anos do IBGE. Cf. <http://rbg.ibge.gov.br/>. 
$1983^{53}$, bem como quatro índices gerais, divididos em "Autores", “Assuntos", "Índice Geográfico" e "Descritores e Palavras-Chave". Deste modo, não estão contemplados na análise realizada os 58 números publicados entre 1984 e 2006, divididos em 16 volumes, em um total de 45 publicações. Em 1988, o número 4 do volume 50 da Revista publicou os mesmos índices para as publicações dos anos de 1984 a 1988, material de referência desconsiderado em nossa análise.

A ausência dos últimos exemplares da RBG na análise realizada não deve, necessariamente, ser considerada falta grave, já que a publicação começou a perder sua importância até então central já no final dos anos de 1960, frente ao avanço de outras publicações, ligadas em geral às Universidades, bem como à própria perda de importância da Geografia no seio do IBGE. Atrelado historicamente a este fato, em parte como causa, em parte como efeito, a ascensão da corrente crítica no pensamento geográfico brasileiro acelerou a perda de importância da publicação, bem como da própria Geografia que se realizava no IBGE, ao criticar a filiação da ciência geográfica às demandas estatais.

De todo modo, permanece em aberto a possibilidade de revisão e aprofundamento da análise proposta, com vistas a uma melhor e mais completa compreensão do pensamento geográfico do CNG, em seu conjunto. Neste sentido, já foram apontadas algumas críticas e limitações, que devem ser consideradas no conjunto da presente análise.

\subsubsection{Natureza editorial dos materiais}

O "Índice de Assuntos", índice privilegiado na análise por expor as linhas temáticas dos materiais, não indica a natureza editorial destes materiais, com exceção das Resenhas. Assim, procedeu-se à classificação dos materiais, a partir das listagens dos Sumários ou a partir da observação direta do material, quando o tipo do mesmo está ausente inclusive no Sumário ${ }^{54}$. Por "materiais" entende-se: "Artigos", “Atividades Geográficas", "Bibliografia", "Comentários", "Comunicações", "Conferências", "Editorial”, "Inquéritos Geográficos", "Noticiário", "Outros", "Resenha" e "Transcrições". Tais indicações são dadas pela própria Revista, com exceção de “Outros”. Neste grupo incluímos apenas 3 materiais, todos

\footnotetext{
${ }^{53}$ Foram 180 números publicados em 177 publicações devido à ressalva já assinalada referente aos anos de 1978, 1979 e 1983.

${ }^{54}$ Em 1967, a RBG passa por sua primeira reformulação em sua diagramação. Além de mudanças nos elementos visuais, foram abolidas do Sumário as indicações da natureza de cada material contido na publicação. Tais indicações reaparecem no Sumário a partir de 1975. Em 1969, apenas a seção "Noticiário" volta a ser indicada no Sumário.
} 
publicanos no volume 1 da Revista: a "Apresentação" da então nova publicação; a transcrição da "Resolução" que determina a publicação da Revista; e o "Índice Acumulado", que se estende do volume 1 ao 45 e cujas referências o "Índice de Assuntos" apresenta agrupadas.

Até 1974, antes da reformulação do Sumário, a RBG se dividia regularmente em "Artigos", "Vultos da Geografia do Brasil", "Comentários" (que agrupava as seções de publicação intermitente "Comunicações", "Conferências", "Resenha" e "Transcrições"), "Tipos e Aspectos do Brasil" e "Noticiário", nesta ordem.

A seção "Vultos da Geografia do Brasil" totaliza 124 ocorrências. Entre sua primeira publicação, no volume 1 (1939), e o volume 25 (1963), quando deixa de ser publicada, está ausente apenas no volume 22 (1960). Ao biografar importantes e variadas figuras que contribuíram com o saber geográfico no Brasil, esta seção agiu no sentido de constituir um senso de comunidade e uma tradição disciplinar de pensamento para um campo de reflexão ainda bastante jovem e com formulações teóricas bem menos consolidadas do que outros campos de conhecimento ligados às ciências sociais.

A seção "Tipos e Aspectos do Brasil" está presente em quase todos os volumes, totalizando 163 ocorrências, até deixar de ser publicada, a partir do volume 46 (1984). Dentro deste intervalo, não foi publicada nos volumes 25 (1963), 32 (1970), 33 (1971) e ao longo do intervalo que se estende do volume 35 (1973) ao 41 (1979). ${ }^{55}$

A partir do n. 1 do volume 2 (1940a) da Revista foi inaugurada a seção "Inquéritos Geográficos". Conforme indicado na publicação inaugural da seção e constante na seção "Noticiário" 56 , o Diretório Central do CNG formulou questionários voltados às diversas especialidades da Geografia para serem respondidos pelo corpo de consultores técnicos nacionais e diretores técnicos regionais do Conselho.

A interessante iniciativa teve claro viés metodológico e pretendeu constituir materiais de referência para as muitas pesquisas que seriam realizadas no âmbito do CNG. Segundo a transcrição do questionário direcionado aos colaboradores, percebe-se que a intenção era produzir 38 inquéritos, nos mais diversos assuntos de interesse geográfico. Publicou-se, contudo, apenas 7 inquéritos, nas áreas de FITOGEOGRAFIA, FOTOGRAMETRIA, ETNOGRAFIA,

\footnotetext{
${ }^{55}$ Para uma análise do papel acadêmico e político-cultural da seção "Tipos e Aspectos do Brasil", cf. DAOU, Ana Maria Lima. Tipos e aspectos do Brasil: imagens e imagem do Brasil. In: ROSENDAHL, Zeny; CORRÊA, Roberto Lobato. (Orgs.) Paisagem, imaginário e espaço. Rio de Janeiro: Ed. UERJ, 2001, p. 135-162; ANGOTTI-SALGUEIRO, Heliana. A construção de representações nacionais: os desenhos de Percy Lau na Revista Brasileira de Geografia e outras "visões iconográficas" do Brasil moderno. Anais do Museu Paulista, v. 13, n. 2, 2005, p.21-72; SILVA, Jorge Luiz Barcellos da. Atlas Geográfico do Brasil. Leituras da territorialidade e a construção da brasilidade. São Paulo, 2006, 265 f. Tese (Doutorado) - Pontifícia Universidade Católica de São Paulo.

${ }^{56}$ IBGE. Um inquérito de alta cultura geográfica. Revista Brasileira de Geografia, Rio de Janeiro: IBGE, v. 2, n. 1, 1940a, p. 97-99. (Noticiário.)
} 
LIMITES, GEOGRAFIA URBANA, GEOGRAFIA REGIONAL DO BRASIL e OCEANOGRAFIA, e a partir do volume 4 (1942) a Revista já não contava mais com a seção.

A seção "Noticiário" deixou de ser publicada a partir de 1969 e, com isso, a Revista passou a ter uma aparência mais exclusivamente acadêmica, perdendo parte de sua função institucional e política no seio da comunidade de geógrafos.

A partir de 1975, com a reformulação do Sumário, a tradicional seção "Comentários" torna-se mais clara. Até então esta seção agrupava materiais diversos, cuja natureza se tornava clara em notas de rodapé ou com a leitura da introdução dos mesmos. Assim, basicamente as seções "Comunicações", "Conferências", "Resenha" e "Transcrições” tornam-se explícitas no Sumário a partir de 1975, embora já fizessem parte da rotina da Revista desde seu início, de maneira não explícita. Por algum motivo, a Biblioteca Central do IBGE optou por assinalar apenas quais materiais constituem "Resenha", ainda que com algumas ausências. Desta forma, é possível tornar mais claro a natureza de cada material contido dentro da seção “Comentários", porém este trabalho exigiria a análise de cada material isoladamente e optamos por não o realizar. Assim, a quantidade de materiais, exposta a seguir, relativas a cada seção não espelha com total clareza a natureza editoral dos trabalhos publicados, no que se refere à seção "Comentários".

A partir do volume 29 de 1967, em comemoração aos 30 anos do CNG, além da reformulação da diagramação da RBG e do Boletim Geográfico, passou-se a publicar um “Caderno Especial” denominado "Atlas de Relações Internacionais", inserido de forma anexa à Revista, fora de sua estrutura. A partir de um recorte espacial grosso modo nacional, tal Caderno possuía a estrutura de uma revista de divulgação para o público comum, embora a atualidade de seu conteúdo possua, ainda hoje, grande possibilidade de uso para a preparação de aulas para o ciclo básico. Seu acento era histórico e geopolítico, por isso, padece, mais do que o conteúdo da RBG, propriamente, de desatualização histórica. De todo modo, não encontramos qualquer trabalho acadêmico a versar sobre o conteúdo destes interessantes Cadernos, um trabalho por ser feito. Tal publicação se estendeu até o último número do volume 38 de 1976 e contou com um total de 40, uma em cada número da Revista. 


\subsubsection{Metodologia de análise}

Como já assinalado, a publicação números $1 / 2$, volume 47 , de 1985 , publicou o "Sumário" de todos os 180 números da Revista, entre 1939 e 1983, bem como os materiais organizados em quatro diferentes índices. A Biblioteca Central do IBGE, segundo nota explicativa publicada na própria edição da publicação, deu preferência pela indexação de materiais técnico-científicos, bem como das seções "Tipos e Aspectos do Brasil", "Vultos da Geografia do Brasil" e "Resenhas Bibliográficas". "Na elaboração dos Índices, não foram consideradas as seções relativas a noticiários, reportagens etc. No entanto, até mesmo esse tipo de material pode ser localizado através dos Sumários que precedem os Índices.” (IBGE, 1985, p. 5) A análise do material indexado revela, porém, pontualmente, a indexação de quatro listagens bibliográficas referentes a um autor ou assunto, um editorial e três noticiários, em decorrência da relevância histórica e acadêmica destes materiais.

De fato, um grande volume de material não foi indexado, dando-se evidente preferência para materiais de claro cunho científico. Como nos baseamos exclusivamente na indexação proposta pela Biblioteca Central do IBGE, esta talvez seja a principal falha da presente análise. A seção "Noticiário" congregava notícias e relatórios diversos referentes a encontros, congressos, comissões, atividades geográficas, missões em território nacional e no exterior, inaugurações, bem como transcrições de artigos publicados em jornais, discursos, modelos para a realização de pesquisas diversas, normas de publicação de variados materiais e grande quantidade de resoluções do âmbito administrativo, não apenas do CNG, mas de conselhos afins, além de notas de celebração ou de falecimento.

Já a seção "Relatórios, Resoluções e Leis" é vasta nos materiais indicados em seu título. A seção, além de publicar textos áridos ligados à burocracia, servia como canal de diálogo entre diferentes entidades. Por fim, a seção "Bibliografia" visava listar publicações de caráter ou interesse geográficos publicados no ano da publicação e servia como ampla fonte de referências à pesquisa.

Tendo-se em vista o fato, clarificado ao longo do amadurecimento desta pesquisa, de que a ciência geográfica brasileira não se desenvolveu na exclusiva esteira do desenvolvimento acadêmico da disciplina, mas também no âmbito das relações pessoais e das demandas políticas estabelecidas entre os agentes da comunidade que a conformou, a análise específica das seções "Noticiário" e "Relatórios, Resoluções e Leis" pode auxiliar na compreensão da dimensão sociológica desta comunidade e do papel desta dimensão no plano do desenvolvimento das ideias. Um tal esforço, contudo, está amplamente fora das 
possibilidades da presente pesquisa. De todo modo, a restrição ao conteúdo de claro cunho científico ainda abre as possibilidades de análise a um material ainda muito pouco considerado como objeto de pesquisa.

Assim, considerou-se o índice referente a "Assuntos", no qual os materiais são apresentados segundo temas ("palavras-chave"), com base em critério próprio aos técnicos da Biblioteca Central do IBGE. A classificação dos materiais por temas mostrou-se a mais adequada dentre as disponíveis para se refletir sobre as tendências internas ao pensamento geográfico construído pelos colaboradores da RBG. Os demais índices foram desconsiderados.

As páginas referentes ao "Índice de Assuntos", apresentadas no formato PDF, foram convertidas em documento manipulável por editor de texto. Como a conversão nunca é perfeita, realizou-se ampla revisão de modo a corrigir a grande quantidade de erros ortográficos nos títulos dos materiais e nas referências bibliográficas. ${ }^{57}$

Retirou-se da lista as seções "Tipos e Aspectos do Brasil" e "Vultos da Geografia do Brasil" (indicado no "Índice de Assuntos" por "Biografia") devido à natureza específica destes materiais, que mereceriam análise à parte.

Organizou-se uma tabela e se constatou que um mesmo material pode constar diversas vezes no "Índice de Assuntos", já que foi classificado dentro de mais de um tema. Assim, registrou-se 2273 materiais, a maioria com no mínimo duas aparições. Pode-se dar centenas de exemplos, mas em três ocasiões, o mesmo material, no caso artigo, se repete sete vezes:

\footnotetext{
VALVERDE, Orlando. Divisão regional do vale do São Francisco. Revista Brasileira de Geografia, Rio de Janeiro: IBGE, v. 6, n. 2, 1944, p. 179-218. (CLIMATOlOGIA, DiVISÃo REGIONAL, GEOGRAFIA ECONÔMICA, GEOGRAFIA REGIONAL, GEOLOGIA, GEOMORFOLOGIA $\mathrm{e}$ PALEOGEOGRAFIA.)
}

SOARES, Lúcio de Castro. Limites meridionais e orientais da área de ocorrência da floresta amazônica em território brasileiro. Revista Brasileira de Geografia, Rio de Janeiro: IBGE, v. 15, n. 1, 1953, p. 3-122. (BIOGEOGRAFIA, FITOGEOGRAFIA, FLORESTA, FRONTEIRA, GEOGRAFIA FÍSICA, GEOGRAFIA POLÍTICA e GEOGRAFIA REGIONAL.)

Moraes, Cel. João de Mello; PINHeIRo, Maj. Sinval. Primeira expedição cientifica à serra de Paranapiacaba e ao alto Ribeira. Revista Brasileira de Geografia, Rio de Janeiro: IBGE, v. 19, n. 2, p. 123-177; n. 3, p. 255-299; n. 4, p. 445-460, 1957. (ÁGUA MINERAL, GEOGRAFIA ECONÔMICA, HIDROLOGIA, MINERAÇÃO, RECURSOS MINERAIS, GEOGRAFIA FÍSICA e GEOMORFOLOGIA.)

\footnotetext{
57 Solicitamos mais de uma vez à Biblioteca do IBGE, por e-mail, uma eventual listagem de materiais em formato já adequado à manipulação, mas optamos pela conversão manual do arquivo PDF em documento manipulável, já que, apesar do trabalho, economizamos tempo. Não fizemos solicitações por telefone ou pessoalmente. Já a dissertação de mestrado de Adriana de Melo Simas (UERJ, 2008), sob orientação de Mônica Sampaio Machado, realizou semelhante trabalho ao que nos propusemos para o Capítulo 2, mas a superficialidade de sua análise limitou seu uso.
} 
Frente à aparição repetida dos materiais, devido ao enquadramento dos mesmos dentro de mais de um tema, procedeu-se, então, à eliminação de materiais repetidos. Para evitar a perda das entradas propostas pela Biblioteca Central do IBGE, escreveu-se um Macro no Excel $^{58}$ para, de maneira automática, se eliminar as repetições e se aglutinar as diferentes palavras-chaves relativas a cada um dos materiais. Após nova extensiva revisão manual, obteve-se uma lista com 982 materiais diferentes, cada um classificado com uma à sete diferentes palavras-chave.

Embora úteis em diversos aspectos, as palavras-chave propostas pela Biblioteca Central do IBGE são muito numerosas e, por vezes, pouco esclarecedoras ou significativas. São propostas 231 palavras-chave (vide ANEXO A), algumas muito específicas e que impedem a comparação entre diferentes artigos. É o caso, à título de exemplo, de entradas como "ÁBACO (GRÁFICO)" e “DIAGRAMA”, ambos com apenas uma ocorrência; “ÁGUA MINERAL” com quatro ocorrências, sendo que em uma delas não há mais nenhuma palavra-chave, embora o trabalho seja de geografia regional; "CARTÓGRAFO" e "MAPA" (apesar da entrada "CARTOGRAFIA"); “COMPANHIA FORD INDUSTRIAL DO BRASIL”; bem como numerosos ramos econômicos com apenas uma ou duas ocorrências. Há palavras-chave semelhantes, tais como "CLASSIFICAÇÃO

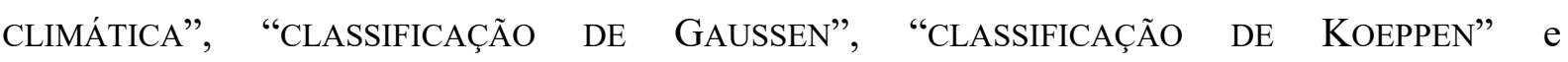
“CLASSIFICAÇÃO DE THORNTHWAITE”, que poderiam ser agrupadas todas na também existente entrada "CLIMATOLOGIA".

Há, ainda, palavras-chave "curinga", aparentemente utilizadas na classificação de materiais de difícil enquadramento dentro de uma categoria. Para trabalhos de história do pensamento geográfico ou de natureza metodológica, a Biblioteca Central do IBGE em geral utilizou a entrada "GEOGRAFIA". Há ainda a entrada "GEOGRAFIA FÍSICA" para classificar materiais eminentemente de Geografia Física mas que não se restringem a um sub-ramo do conhecimento.

Isto posto, reclassificamos cada um dos 982 materiais com o objetivo de reduzir as entradas relativas a cada material para apenas uma palavra-chave. ${ }^{59} \mathrm{O}$ critério de classificação baseou-se, parcialmente, no trabalho de Machado (2009), que realizou trabalho análogo com as dissertações e teses defendidas junto à UFRJ. Algumas ressalvas devem ser feitas.

\footnotetext{
${ }^{58}$ O Macro deve ser atribuído a Renato Magalhães de Souza, um grande amigo cuja ajuda facilitou muito a organização dos materiais.

$59 \mathrm{O}$ desenvolvimento da pesquisa expôs os limites de tal proposta. Alguns materiais são praticamente inclassificáveis dentro de apenas um parâmetro, caso particularmente válido para publicações do âmbito preferencial da Geografia Regional ou da Geografia Econômica. Voltaremos a este ponto ao longo do texto e nas Considerações Finais.
} 
A redução de múltiplas entradas a uma única palavra-chave tem a vantagem de tornar mais clara a visualização da concentração dos trabalhos dentro de cada subárea da ciência geográfica. Ao se utilizar mais de uma palavra-chave, produz-se a distorção de um mesmo ramo da Geografia poder virtualmente estar presente em todos os trabalhos, ainda que cada trabalho possua concentração em uma área específica, impossibilitando uma análise comparativa. Ainda que de fato isso não tenha ocorrido, a observação é especialmente válida para as entradas GEOGRAFIA REGIONAL e GEOGRAFIA ECONÔMICA.

Por outro lado, colocamo-nos frente a um enorme desafio, já que dezenas de trabalhos não são enquadráveis a apenas um sub-ramo do conhecimento geográfico. A leitura de diversos materiais ${ }^{60}$, em primeiro lugar, fez-nos questionar as chamadas áreas de conhecimento "Geografia Física" e "Geografia Humana", segundo terminologia do Conselho Nacional de Desenvolvimento Científico e Tecnológico - CNPq.

Embora seja possível identificar materiais eminentemente dentro de cada área do conhecimento, praticamente não se conseguiu identificar trabalhos totalmente fiéis à classificação imposta ao pensamento. Em termos metodológicos, parece forçoso identificar em muitos trabalhos uma pré-classificação em áreas de conhecimento e isso ocorre, aparentemente, devido ao aspecto prático presente no pensamento dos primeiros colaboradores do IBGE. Do compromisso com a descrição de geografias regionais associado ao fato de os primeiros colaboradores do CNG não serem, de fato, geógrafos de formação em um período no qual as próprias especialidades ainda não haviam se consolidado, resulta um aparente reduzido respeito pelos limites disciplinares do conhecimento.

O que se observou, antes, foi uma crescente especialização da produção acadêmica em termos escalares, dentro de um movimento em que a escala nacional passou a ganhar menos destaque, sendo o fenômeno especialmente visível a partir dos anos 1980.

Assim, em relação à classificação proposta por Machado (2009), realizamos algumas alterações visando, principalmente, fazer jus a algumas particularidades da RBG. Como não se classificou os artigos em Geografia Física e Geografia Humana, também não se identificou os trabalhos de história do pensamento geográfico e de epistemologia com Geografia Humana, até porque, além de discordarmos dessa identificação, observou-se que diversas especialidades da Geografia realizaram trabalhos de natureza histórica ou teórica.

\footnotetext{
${ }^{60}$ A leitura de materiais concentrou-se dentro do recorte histórico proposto pela pesquisa, porém, a organização da análise geral da RBG forçou-nos a, necessariamente, ler o título de todos os materiais, bem como a introdução $\mathrm{e}$, às vezes, quase o trabalho inteiro, de grande número deles.
} 
Também não se identificou trabalhos da área mais ampla da Cartografia com as duas áreas de conhecimento geográfico. As realizações cartográficas do IBGE presentes na RBG merecem comentários mais amplos, a seguir. Por fim, trabalhos do âmbito da temática da “colonização" foram identificados à parte, frente à importância da temática.

Vale ressaltar, ainda, que a consideração aos matérias apenas por sua natureza editorial e por seu título pode causar distorções de interpretação. Há diversas publicações, tais como Excursão ao Amapá: a pororoca (IBGE, 1947), classificado pela RBG simplesmente como POROROCA e por nós como GEOGRAFIA REGIONAL, que não constituem artigos de fato. $\mathrm{O}$ material citado, por exemplo, foi publicado na seção "Comentários", com base numa conferência dada por Esperidião de Queirós Lima ao Instituto de Colonização Nacional. Da expedição realizada pelo conferencista 20 anos antes ao Amapá, o comentador da RBG (identificado apenas por "Redação") registrou um fenômeno interessante, a pororoca, e teceu um comentário de uma página, publicado na Revista. Não se trata, pois, de um trabalho de expressão acadêmica, mas de um simples comentário, cujo conteúdo não pode ser igualado a trabalhos de maior envergadura.

O mesmo ocorre, no mesmo número da Revista, com o comentário de João Capistrano Raja Gabaglia, Introdução à leitura de cartas geológicas (1947), à uma publicação francesa voltada à leitura de cartas geológicas. Diversos outros exemplos poderiam ser dados.

\subsubsection{Reclassificação dos materiais consultados}

No exercício de redução das entradas que identificam o escopo teórico principal de cada material utilizou-se 17 palavras-chave diferentes: HPG / TM, GEOGRAFIA REGIONAL, GEOGRAFIA DA POPULAÇÃO, CARTOGRAFIA, GEOGRAFIA DOS TRANSPORTES, GEOMORFOLOGIA, BIOGEOGRAFIA, Climatologia, GEOGRAFIA POlítiCA, COLONIZAÇÃO, GEOGRAFIA URBANA, PEDOLOGIA, EDUCAÇÃO, GEOGRAFIA ECONÔMICA, GEOGRAFIA AGRÍCOLA, GEOLOGIA e OUTROS.

Procurou-se, com base parcialmente em Machado (2009), preservar as tradicionais áreas de estudo em Geografia, que inclusive aparecem com frequência na classificação proposta pela Biblioteca Central do IBGE. As entradas criadas por nós são HPG / TM, GEOGRAFIA DOS TRANSPORTES, GEOGRAFIA AGRíCOLA e OUTROS. As demais já estão presentes na sistematização efetuada pelo IBGE.

Dentro de HPG / TM (História do Pensamento Geográfico / Teoria e Método) aglutinouse trabalhos tradicionalmente associados à história do pensamento geográfico e às questões 
teóricas e metodológicas. Trabalhos teóricos ou metodológicos que versam sobre uma subárea da Geografia foram inseridos dentro da subárea sobre a qual versam.

A entrada GEOGRAFIA DOS TRANSPORTES reúne artigos identificados pela entrada TRANSPORTE pela Biblioteca Central do IBGE que versam fundamentalmente sobre a questão dos transportes no Brasil. A denominação GEOGRAFIA DOS TRANSPORTES pareceu-nos mais adequada já que princípios lógicos fundamentais do pensamento geográfico foram levados em consideração na abordagem do transporte em relação aos elementos que compõem as paisagens do território nacional. Não se trata de leituras técnica da questão dos transportes, mas de estudos em que o transporte é o elemento dinamizador em termos sociais e econômicos de realidades em diversas escalas de análise.

A entrada GEOGRAFIA AGRÍCOLA, por sua vez, abrange uma variedade maior de temas de pesquisa. Agrupa a quase totalidade dos materiais identificados com a entrada AGRICULTURA, pela Biblioteca Central do IBGE, bem como materiais identificados pelas entradas ECOLOGIA, COLONIZAÇÃo, GEOGRAFIA AGRÁRIA, USO DO SOLO, PEDOLOGIA, GEOGRAFIA ECONÔMICA e REFORMA AGRÁRIA. Os materiais identificados por AGRICULTURA pela Biblioteca Central do IBGE que foram classificados por nós fora da entrada GEOGRAFIA AGRÍCOLA concentram-se na entrada GEOGRAFIA ECONÔMICA.

Já a entrada OUTROS, por nós adotada, reúne uma multiplicidade de temas pouco recorrentes na história da $\mathrm{RBG}$, cuja identificação por palavras-chave independentes não se mostrou relevante. São 32 trabalhos (aproximadamente $3,3 \%$ do total de materiais considerados), no total, nas áreas, basicamente, de Antropologia (quatro ocorrências, incluindo um trabalho sobre Folclore), Bibliografia (incluindo duas relações bibliográficas de trabalhos sobre a Amazônia) Ecologia (sete ocorrências), Saúde (quatro ocorrências), Oceanografia (duas ocorrências), bem como Etnografia, Geofísica, História Social, Indigenismo e Nutrição, cada uma com uma ocorrência.

Por fim, aproveitando-se uma palavra-chave empregada pela Biblioteca Central do IBGE, deu-se destaque aos trabalhos que versam especificamente sobre COLONIZAÇÃO, haja vista a importância que este tema adquiriu no desenvolvimento dos trabalhos do $\mathrm{CNG}^{61}$

\footnotetext{
${ }^{61}$ Note-se, a este respeito, o aspecto enganoso no exercício de classificação de materiais a partir de uma única entrada, uma vez que, nesta específica situação, preferiu-se identificar trabalhos eventualmente de GEOGRAFIA ECONÔMICA, PEDOLOGIA ou GEOGRAFIA DA POPULAÇ̃̃o sob a entrada COLONIZAÇ̃̃o. Com efeito, com o amadurecimento da pesquisa, a classificação dos materiais segundo uma única palavra-chave demonstrou-se limitante. Um sistema de classificação baseado em dois ou três termos classificatórios poderia ser mais frutífero para a presente análise, mas sua organização levaria meses, impossibilitando seu imediato desenvolvimento.
} 


\subsubsection{Recorte espacial de análise}

Machado (2009, p. 179-180) classifica o material analisado em sua pesquisa em termos de escala geográfica e recorte espacial. Com a noção de escala geográfica a autora classificou os materiais em "mundial", "nacional", "regional" e "local". Já em termos de recorte espacial, a autora faz referência aos estados da Federação onde os estudos foram realizados.

Embora não tenhamos nos atentado em nosso trabalho à diferenciação proposta por Machado (2009), em parte pela necessidade de verticalização de leituras de alguns materiais, em parte porque a diferenciação proposta pela autora se sobrepõe, algumas dificuldades enfrentadas por ela quanto a este aspecto são idênticas às nossas.

Em relação às escalas geográficas, a autora assinala que a "escala regional, de mais difícil identificação, aglutinou tanto os estudos que tratavam de eventos abrangendo um ou mais estados, quanto investigações que se detinham em zonas dentro de um próprio estado." (MACHADO, 2009, p. 179) Para além da ambiguidade escalar guardada pelo próprio conceito, a autora menciona ainda

\footnotetext{
que a classificação dessa escala não corresponde, em sua grande maioria, à concepção dos tradicionais estudos regionais dos anos 30, que, aglutinando vários estudos a partir de suas características fisiográficas, buscavam uma leitura territorial capaz de minimizar as tendências centrífugas típicas da Primeira República. (MACHADO, 2009, p. 179)
}

Com efeito, observa-se uma necessidade, por parte do Estado, de reconhecimento de áreas de dimensão variável com a finalidade de ocupação e exploração econômica. Algumas das expedições geográficas à encargo do $\mathrm{CNG}$ e que renderam valiosos frutos no âmbito da pesquisa geográfica foram, inclusive, patrocinadas por empresas estrangeiras, o que torna mais nítido, acima de tudo, a motivação econômica das expedições. Em escala nacional, todavia, são numerosos os trabalhos que versam sobre "fronteira", em um sentido essencialmente político, neste sentido, dando destaque à importância que o território nacional, em sua integralidade, tinha junto ao pensamento estatal. Vale reiterar, ainda, como a leitura neutra e naturalizante da Geografia de sotaque francês atendia às necessidades centralizadoras estatais, na medida em que naturalizavam a divisão territorial, simultaneamente sobrepondose ideologicamente aos interesses oligárquicos regionais e retirando da dimensão histórica, por intermédio da lógica do possibilismo, as possibilidades de determinação social.

Quanto ao recorte espacial, Machado (2009) assinala a existência de trabalhos que não se limitam a um estado da Federação, mas abrangem as grandes regiões. Este fato é bastante nítido nas publicações da RBG e não poderiam ser desconsideradas, já que há trabalhos que 
pensam as grandes regiões em si, antes de um mero agrupamento de estados e atendem às aspirações nacionais de um Estado centralizador. Machado (2009, p. 180) assinala a existência de trabalhos que não se limitavam a apenas um estado "por abrangerem trechos de rios ou rodovias". Embora tenhamos atentado para recortes regionais de estudo, que não obedecem a limites interestaduais, não realizamos considerações específicas a este respeito devido ao acréscimo no volume de análise que seria necessário.

Não foi aproveitado o "Índice Geográfico" fornecido pela Biblioteca Central do IBGE, pois, em termos práticos, sua utilização exigiria nova transformação de trecho do arquivo PDF - referente a este Índice - em arquivo manipulável, ampla revisão ortográfica, além do desenvolvimento de um novo Macro para o cruzamento com o "Índice de Assuntos". Este cruzamento, contudo, ainda exigiria uma igual reclassificação dos materiais, devido a uma questão metodológica. Em termos metodológicos, a Biblioteca Central classifica os materiais preferencialmente em escala municipal, o que garante reduzida margem ao agrupamento e à comparação entre os mesmos. Utiliza, ainda, referências variadas, tais como topográficas, por exemplo "Serra do Mar" ou "Ilha de Marajó", fitogeográficas como "Zona da Mata" ou ainda hidrográficas como "Rio Orenoco", que igualmente dificultam a comparação entre os materiais. Assim, a classificação manual dos materiais em termos de recorte espacial, a partir do título ou através da leitura da introdução dos mesmos, mostrou-se mais simples, rápida e segura. 


\subsection{ANÁLISE QUANTO AO TEMA DOS MATERIAIS CONSIDERADOS}

Entre 1939 e 1983 foram publicados 182 números da RBG (76,5\% do total de publicações). Até 1956, intervalo temporal considerado nesta pesquisa, foram publicados 72 números da Revista, o que equivale a 39,6\% das publicações lançadas até 1983. O percentual de $39,6 \%$ das publicações concentra $40,1 \%$ de todos os materiais listados pela Biblioteca Central do IBGE, em 1985, ou seja, no seu aspecto geral, a Revista manteve homogêneo o volume de materiais publicados. Ainda que todos os materiais tenham sido classificados em termos de uma subárea de estudo em Geografia, se se comparar a natureza editorial dos materiais publicados entre 1939 e 1956 com aqueles publicados entre 1939 e 1983, o aspecto mais relevante a ser observado é a maior concentração de Resenhas entre 1939 e 1956 (56,2\%) e maior concentração de publicações na seção Comentários a partir de 1957 (70,3\%).

TABELA 1 - TEMAS DE PESQUISA PUBLICADOS MAIS

FREQUENTEMENTE NA RBG ATÉ 1956 E EM RELAÇÃO AO TOTAL REFERENTE A CADA TEMA PUBLICADO ATÉ 1983

\begin{tabular}{|c|c|c|c|}
\hline \multirow{2}{*}{ TEMA } & \multicolumn{2}{|c|}{ ATÉ 1956} & \multirow{2}{*}{$\begin{array}{l}\text { \% EM REL. AO TOTAL } \\
\text { PUBLICADO ATÉ } 1983\end{array}$} \\
\hline & QTDE & $\%$ & \\
\hline GEOGRAFIA REGIONAL & 71 & 18,0 & 54,6 \\
\hline $\mathrm{HPG} / \mathrm{TM}$ & 38 & 9,6 & 45,8 \\
\hline GEOMORFOLOGIA & 32 & 8,1 & 37,2 \\
\hline GEOGRAFIA ECONÔMICA & 32 & 8,1 & 27,8 \\
\hline CARTOGRAFIA & 31 & 7,8 & 51,7 \\
\hline GEOGRAFIA POLÍTICA & 30 & 7,6 & 51,7 \\
\hline PARCIAL & 234 & 59,2 & \\
\hline CLIMATOLOGIA & 26 & 6,6 & 44,8 \\
\hline BIOGEOGRAFIA & 21 & 5,3 & 36,2 \\
\hline GEOGRAFIA DA POPULAÇÃO & 20 & 5,1 & 47,6 \\
\hline GEOGRAFIA AGRÍCOLA & 19 & 4,8 & 24,4 \\
\hline COLONIZAÇÃO & 17 & 4,3 & 81,0 \\
\hline PEDOLOGIA & 14 & 3,5 & 53,8 \\
\hline OUTROS & 13 & 3,3 & 40,6 \\
\hline GEOGRAFIA DOS TRANSPORTES & 11 & 2,8 & 64,7 \\
\hline GEOGRAFIA URBANA & 11 & 2,8 & 11,7 \\
\hline GEOLOGIA & 6 & 1,5 & 46,2 \\
\hline EDUCAÇÃO & 3 & 0,8 & 23,1 \\
\hline TOTAL & 395 & 100,0 & 40,1 \\
\hline
\end{tabular}

Os 6 temas publicados com maior frequência até 1956 representam 59,2\% do total publicado no período. Em destaque, os temas que concentram mais de 50\% das publicações até 1956, em relação ao total publicado até 1983 dentro de cada tema. Uma análise qualitativa permite estabelecer forte relação entre os temas mais frequentes. 
Entre 1939 e 1956, os materiais publicados nas subáreas de GEOGRAFIA REGIONAL, HPG / TM, GEOMORFOLOGIA, GEOGRAFIA ECONÔMICA, CARTOGRAFIA e GEOGRAFIA POLÍTICA representam $59,2 \%$ do total publicado no período.

Já se compararmos o intervalo 1939-1956 com o total de publicações até o ano de 1983, as subáreas COLONIZAÇÃO, GEOGRAFIA DOS TRANSPORTES, GEOGRAFIA REGIONAL, PEDOLOGIA, GEOGRAFIA POLÍTICA, CARTOGRAFIA, GEOGRAFIA DA POPULAÇÃO, GEOLOGIA, HPG / TM e CLIMATOLOGIA apresentam uma concentração maior de publicações, já que estas subáreas concentram de 44,8 a $81 \%$ das publicações de seus respectivos temas, embora o intervalo considerado pela pesquisa concentre apenas $40,1 \%$ de todos os materiais publicados. As seis primeiras subáreas acima consideradas concentram mais de $50 \%$ das publicações dentro de seus respectivos temas, em relação ao total publicado até 1983.

Entre os seis temas de pesquisa que concentram mais de 50\% das publicações dentro de seus respectivos temas até 1956, três deles - GEOGRAFIA REGIONAL, CARTOGRAFIA e GEOGRAFIA POLÍTICA - estão também entre os temas mais populares em relação à totalidade dos temas que aparecem até 1956. Porém, os outros três temas de pesquisa que concentram mais de 50\% das publicações dentro de seus respectivos temas até 1956 - COLONIZAÇÃO, GEOGRAFIA DOS TRANSPORTES e PEDOLOGIA - estão diretamente relacionados aos temas mais populares contemplados pela Revista até a referida data.

No extremo oposto, mas igualmente revelador, em termos quantitativos, trabalhos na subárea de GEOGRAFIA URBANA apresentam reduzida concentração tanto em relação à ocorrência dos demais temas até 1956 (2,8\%), quanto em comparação ao total de publicações sobre o tema até $1983(11,7 \%)$.

Antes de se proceder à análise qualitativa dos números expostos acima, bem como à exposição de exemplos representativos, é válido, ainda, realizar-se análise quantitativa similar em relação à classificação por temas proposta pela Biblioteca Central do IBGE. Como já dito, o uso de 231 entradas para a classificação de 982 materiais é excessivo, porém, alguns números são reveladores e quase evidentes por si próprios. ${ }^{62}$

Dentre os temas mais frequentes, destacam-se FRONTEIRA, GEOPOLÍTICA, COLONIZAÇÃO e GEOGRAFIA POLÍTICA; DISTRIBUIÇÃO ESPACIAL DA POPULAÇÃO, RELEVO e GEOGRAFIA FÍSICA também devem ser lembrados, porém, com ressalvas. Estes sete temas apresentam mais de 10 publicações entre 1939 e 1983 e concentram mais de 60\% de suas publicações até 1956.

\footnotetext{
${ }^{62}$ Vale ressaltar que, no caso da análise a partir da classificação proposta pela Biblioteca Central, um artigo pode ser classificado com mais de uma palavra-chave, assim, não há uma correspondência direta entre a frequência de ocorrência dos temas e o número de materiais. Em outras palavras, as aparições das entradas não correspondem necessariamente ao número de materiais publicados dentro de cada tema.
} 
No sentido oposto, entre os temas que apresentam menor concentração dentre os números da RBG publicados até 1956, destacam-se os relacionados às áreas de GEOGRAFIA URBANA, INDÚSTRIA, GEOGRAFIA QUANTITATIVA, GEOGRAFIA AGRÁRIA e ECOLOGIA. Além disso, contabilizou-se 20 entradas com mais de 10 aparições até 1983 e menos de $20 \%$ concentradas até 1956, ou seja, materiais com um volume mínimo considerável de publicações, porém, pouco frequentes até 1956: AGRICULTURA, COMÉRCIO, HIDROLOGIA, GEOGRAFIA URBANA, MIGRAÇÃO, URBANIZAÇÃO, LOCALIZAÇÃO INDUSTRIAL, RECURSOS NATURAIS, TRABALHO, ECOLOGIA, INDUSTRIALIZAÇÃO, INDÚSTRIA, GEOGRAFIA AGRÁRIA, ECONOMIA, EDUCAÇÃO, ESTRUTURAÇÃO DO ESPAÇO, GEOGRAFIA QUANTITATIVA, HIERARQUIA URBANA, PLANEJAMENTO REGIONAL e REGIONALIZAÇÃO.

\section{GRÁFICO 1 - TEMAS dE PESQUISA PUBLICADOS MAIS FREQUENTEMENTE NA RBG ATÉ 1956 E EM RELAÇÃO AO TOTAL REFERENTE A CADA TEMA PUBLICADO ATÉ 1983}

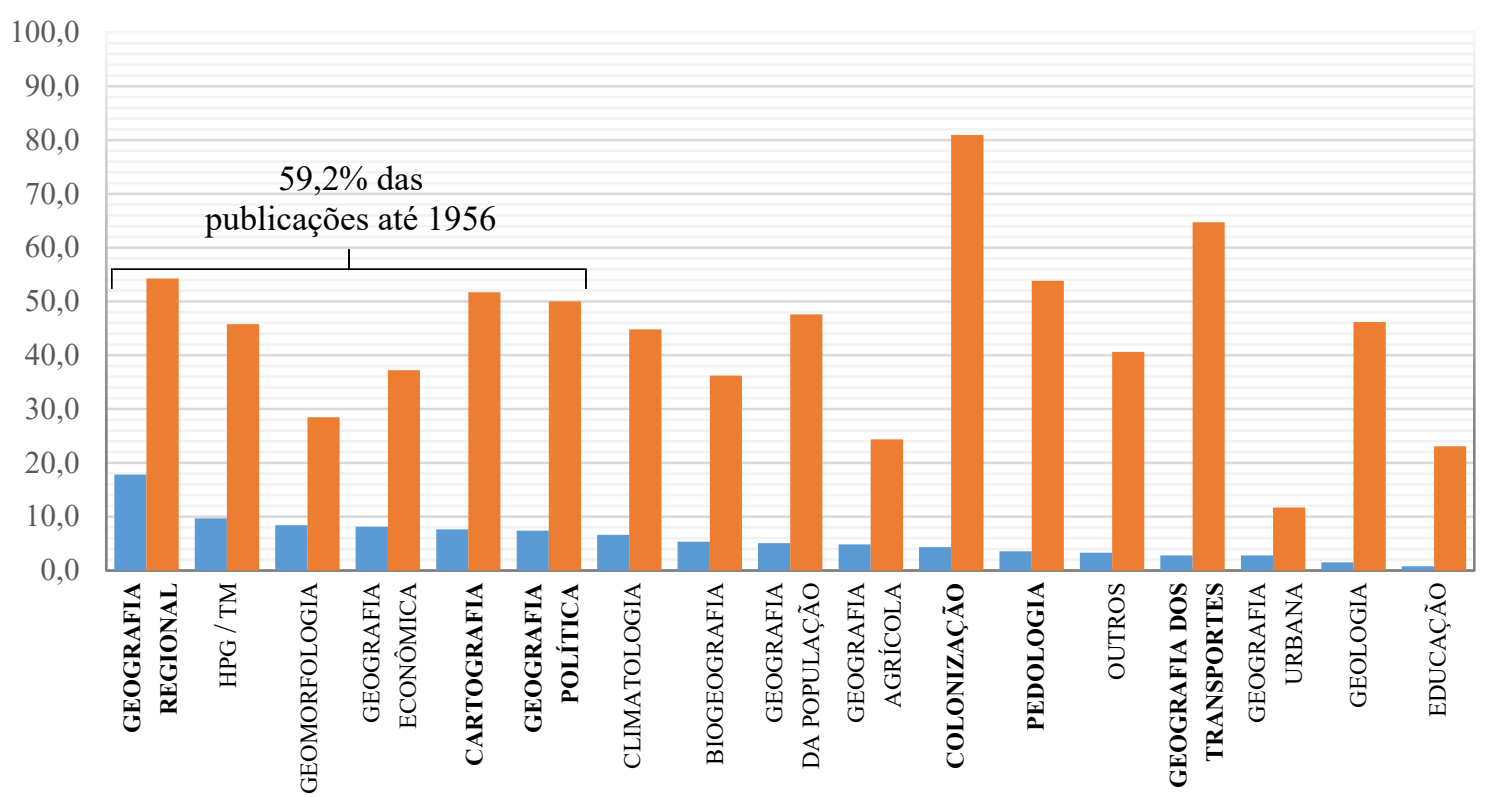

Os 6 temas publicados com maior frequência até 1956 representam 59,2\% do total publicado no período. Em destaque, os temas que concentram mais de 50\% das publicações até 1956, em relação ao total publicado até 1983 dentro de cada tema. Uma análise qualitativa permite estabelecer forte relação entre os temas mais frequentes. 


\subsubsection{Objeto da Geografia, demanda do Estado}

Como já afirmado e passível de observação na TABELA 1 (cf. também GRÁFICO 1), a partir da classificação temática proposta na presente pesquisa, COLONIZAÇÃO, GEOGRAFIA DOS TRANSPORTES, GEOGRAFIA REGIONAL, PEDOLOGIA, GEOGRAFIA POLÍTICA e CARTOGRAFIA concentram quase $60 \%$ das publicações de todos os materiais até $1956 \mathrm{e}$, por isso, são os temas mais populares da RBG ao longo deste período. Dentre estes, GEOGRAFIA REGIONAL, CARTOGRAFIA e GEOGRAFIA POLÍTICA, além de COLONIZAÇÃO, GEOGRAFIA DOS TRANSPORTES e PEDOLOGIA merecem destaque, já que, em comparação ao total publicado até 1983, concentram mais de 50\% das publicações dentro de seus respectivos temas até 1956. Identificados os temas de pesquisa mais populares na RBG, selecionou-se para leitura alguns materiais consagrados pela literatura geográfica, com base especialmente em Almeida (2000) e Simas (2008). Na ausência de referências por fontes secundárias, buscou-se consultar os materiais aparentemente mais relevantes a partir da leitura da introdução.

Mesmo centrando-se a análise sobre apenas 9 dos 17 temas de pesquisa mais populares, o volume de materiais demonstrou-se ainda muito vasto. Para a redação final, fomos obrigados a selecionar alguns temas que consideramos essenciais para a Geografia que se praticava no IBGE e que exerciam uma função articuladora frente aos demais. São eles: CARTOGRAFIA, GEOGRAFIA POLÍTICA e GEOGRAFIA ECONÔMICA. Os demais temas não foram desconsiderados, mas aparentemente articulam-se em função destes. ${ }^{63}$

A TABELA 1 releva, todavia, mais do que a mera popularidade de certos temas nas publicações da RBG. Pode-se pressupor uma complementaridade temática entre as linhas de pesquisa mais populares, que conduziria a análise geral a reforçar a identificação do objeto da ciência geográfica, em seu labor junto ao Estado. Esta complementaridade, sem equívoco, mostrou-se factual a partir da leitura seletiva de alguns materiais publicados dentro de cada uma das entradas mais populares.

Buscando-se, em um exercício de síntese, identificar o que há de comum aos materiais consultados, além da complementaridade temática, arriscamo-nos a afirmar que o movimento de tornar a ciência geográfica moderna, ancorada na Cartografia, parte colaborativa do projeto de Estado nacional liderado por Getúlio Vargas, muito pouco tem de fortuito, em termos

\footnotetext{
${ }^{63}$ A redação final de uma dissertação pode mascarar as dificuldades da pesquisa, como costumeiramente os autores buscam fazê-lo. O fato, contudo, é que a meta era, mesmo, analisar um volume considerável de cada um dos nove temas de maior destaque, de modo a corroborar, com fartura de exemplos, a natureza política do saber geográfico. (Cf., a este respeito, as Considerações Finais.) Este plano, sejamos sinceros, demorou para tornar-se nítido e sua inviabilidade, tardou ainda mais, mesmo sob vozes mais experientes. Caso tivéssemos um plano de leitura mais claro desde o início, poderíamos ter explorado os textos de outra forma na redação final.
} 
epistemológicos. Tanto a relação que se pode estabelecer entre os temas de mais frequente preocupação entre os geógrafos quanto a forma de exposição do objeto geral sobre o qual se debruçavam os geógrafos estão relacionadas à conjuntura histórica e às possibilidades de apreensão da realidade historicamente proporcionadas pela Geografia.

Isto posto, é válido expor-se o que doravante acreditamos ser, sob a ótica dos colaboradores do $\mathrm{CNG}$ que publicaram materiais na RBG, o objeto da ciência geográfica. Segundo Christovam Leite de Castro, três grupos de atividades podem ser consideradas geográficas: "a medição do território, a representação do território e a interpretação do território". O geógrafo moderno se ocuparia da terceira atividade, a interpretação do território, levando-se em consideração o princípio científico da explicação dos fenômenos e da interpretação que não desconsidere o homem e que tenha um sentido de utilidade. (IBGE, 1944, p. 313) ${ }^{64}$ A partir da ótica de diferentes subáreas da Geografia, os geógrafos e colaboradores do CNG tinham como objeto de estudo o território nacional, em um trabalho que de fato não se restringia à medição do mesmo, mas se ocupava também de sua representação, interpretação e organização.

Segundo Draibe:

No que tange à extensão da 'autoridade' e à centralização de dispositivos de controle sobre a 'realidade nacional', a criação de um sistema nacional de estatística foi passo importante, conferindo maior consistência ao monopólio da informação por parte do Executivo Federal e, ao mesmo tempo, oferecendo subsídios à elaboração das políticas econômicas. (DRAIBE, 2004, p. 85)

Dentro do contexto histórico do Estado Novo, estendendo-se por pelo menos à década posterior ao seu fim,

o saber geográfico apresenta-se como um instrumento bastante útil ao poder, por sua condição estratégica e capacidade de inventariar o território nacional. O processo de concentração de poder no Estado, no primeiro governo Vargas, expressou-se também na intensa formulação oficial de políticas territoriais explícitas no sentido de se conhecer geograficamente o país. (ABRANTES, 2014, p. 3)

Neste sentido, se a capacidade de apreensão da realidade de um determinado ramo do saber se revela em uma coerente estrutura conceitual, é razoável pressupormos que a forma por meio da qual a ciência geográfica apropriava-se intelectualmente do território nacional e da organização de seus elementos constitutivos, embora tenha sido introduzida ou aperfeiçoada no Brasil por geógrafos estrangeiros, especialmente franceses, carecia da imperativa solicitação do Estado, que desencadearia o desenvolvimento de tal ramo de saber.

\footnotetext{
${ }^{64}$ Fala de apresentação proferida por Christovam Leite de Castro, segundo a Redação da RBG. Cf. quadro em ZARUR, Jorge. Geografia: ciência moderna ao serviço do homem. Revista Brasileira de Geografia, v. 6, n. 3, 1944, p. 313.
} 
Assim, caberia a geógrafos estrangeiros como Leo Waibel (1949), com um claro discurso de aplicabilidade e desenvolvimento econômico do território, debruçar-se sobre a imperiosa questão nacional da colonização. O território nacional ou, mais precisamente, a questão da organização do território nacional, parece ser o objeto da ciência praticada por ele.

$\mathrm{Da}$ análise conjunta dos materiais tematicamente mais frequentes na RBG, podemos arriscar a afirmação de que esta forma de apreensão da ordem dos elementos constitutivos do território nacional - da geografia do território nacional -, se expressa, de forma muito lógica, segundo um raciocínio cartográfico. São diversos os exemplos de materiais cujos conteúdos parecem proceder à leitura ou à construção de um carta geográfica, em um intento de localizar, distribuir e descrever os elementos que seriam mais representativos de uma dada localidade, segundo o julgamento do pesquisador.

De fato, a análise dos materiais publicados sob a entrada CARTOGRAFIA, quando comparados aos demais materiais e ao próprio histórico de desenvolvimento do CNG no seio do aparelho estatístico nacional, revelam a importância primordial da Cartografia tanto para o desenvolvimento de um campo profissional para geógrafos quanto para o desenvolvimento da epistemologia geográfica.

Assim, na exposição sumária das principais linhas temáticas publicadas na RBG, por sua natureza precípua, iniciaremos pela apresentação dos materiais de natureza essencialmente cartográfica.

\subsubsection{Cartografia nas atividades e no pensamento}

Os materiais publicados na RBG sob a entrada CARTOGRAFIA concentram 51,7\% de todas as publicações até 1956, além de ser o quinto tema mais popular entre o início da publicação da RBG e a referida data. Foram 31 materiais publicados sob essa entrada, publicados em diversas seções. ${ }^{65}$

O exame conjunto destas publicações, em seu aspecto superficial, revela que, de modo geral, as mesmas estão revestidas de um caráter técnico, em dois sentidos. Primeiro, a cartografia surge como um instrumento com um conjunto próprio de princípios e técnicas a serem divulgadas e desenvolvidas. Cerca de $40 \%$ dos materiais, 12 no total, versam sobre o

\footnotetext{
${ }^{65}$ Um elevado número de publicações sobre cartografia aparecem nas seções "Noticiário" e "Atividades Geográficas", que não foram contabilizadas na presente análise, embora tenham sido largamente consultadas. São trabalhos de natureza menos acadêmica, mas que revelam uma importantíssima etapa do processo de consolidação da atuação da Geografia junto ao Estado.
} 
ensino e a divulgação de técnicas e instrumentos cartográficos, determinações astronômicas, uso adequado de escala, uso da cartografia para fins censitários e diferentes possibilidades de representação cartográfica. Bianchi (1942), por exemplo, versa sobre o uso da fotogrametria para reconhecimento topográfico preliminar de extensas áreas, assunto que seria, nos anos seguintes, intensamente debatido no meio estatal.

O trabalho cartográfico, além de se utilizar de técnicas e metodologias específicas, constitui-se ele próprio um trabalho de natureza técnica, basilar para o desenvolvimento econômico e para a realização de pesquisas as mais diversas, delimitando a segunda faceta de caráter técnico a compor o aspecto superficial das publicações de cunho cartográfico.

Do conteúdo explicitamente cartográfico publicado pela RBG - que, além de artigos e comentários acadêmicos, inclui noticiário sobre atividades geográficas, encontros e eventos acadêmicos, bem como leis, resoluções e decretos (estes publicados preferencialmente no Boletim Geográfico) - pode-se identificar como preocupação fundamental do CNG, em seus primeiros anos, quatro eixos de trabalho, intensamente inter-relacionados: a revisão da Carta do Brasil ao milionésimo, a confecção de mapas municipais, a Campanha das Coordenadas Geográficas das sedes dos municípios brasileiros e a precisa delimitação de limites internacionais e interestaduais. ${ }^{66}$

Estes quatro eixos de trabalho desenvolvidos pelo CNG desde sua criação estavam relacionados aos Decretos-Lei n. 237 e n. 311 , de 2 de fevereiro e 2 de março de 1938, respectivamente.

A ementa do Decreto-Lei n. 237 é a regulação dos trabalhos voltados à realização do Recenseamento Geral da República de 1940. Dentre os 23 objetivos a serem cumpridos pelo Recenseamento previstos no Art. $9^{\circ}$ do Decreto-Lei, os quatro primeiros foram de incumbência direta do $\mathrm{CNG}$ :

a) a revisão da área do Brasil e do seu parcelamento, segundo as unidades federadas e os municípios, efetuando-se, tambem, se possivel, o computo das áreas distritais;

b) a descrição sistemática das divisas dos distritos e municípios;

c) a revisão da Carta do Centenário da Independência ao milionésimo;

d) a elaboração do Atlas Estatístico Corográfico Municipal; (BRASIL, 1938) ${ }^{67}$

\footnotetext{
${ }^{66}$ As atividades cartográficas assumidas pelo Conselho não se resumem a estas. Pode-se citar, por exemplo, a Comissão de Uniformização da Cartografia Brasileira, cujos trabalhos atrasaram justamente em função dos eixos de trabalho mais urgentes em decorrência do Censo de 1940. Vale ressaltar a elevada quantidade de engenheiros e, principalmente, militares que, à época, realizavam os principais trabalhos de cartografia do país. Cf. IBGE. Comissão de uniformização da cartografia brasileira. Revista Brasileira de Geografia, v. 1, n. 4, 1939e, p. 124125. (Noticiário.)

67 Disponível em: <http:/www2.camara.leg.br/legin/fed/declei/1930-1939/decreto-lei-237-2-fevereiro-1938350962-publicacaooriginal-1-pe.html> Acesso em 18 jan. 2016.
} 
Estas atribuições foram previstas na própria estrutura do Serviço de Coordenação Geográfica do CNG, composto por quatro seções e uma diretoria e instalado provisoriamente, como vimos, em caráter de urgência visando ao Recenseamento de 1940. A $2^{\mathrm{a}}$ e $3^{\mathrm{a}}$ Seções do SCG tinham por finalidade:

a 2.a seção, da Carta ao Milionésimo, procederá à revisão e atualização da carta
geográfica do país, abrangendo, cálculos e desenhos cartográficos, revisão e
cálculos da área do Brasil e seus parcelamentos, das unidades Federadas,
Municípios e Distritos, elaboração de Cartas Gerais reduzidas, realização da
campanha de levantamento das coordenadas geográficas das sedes dos municípios
e demais trabalhos de Campo, indispensáveis;
a 3. ${ }^{a}$ secção, de Cartografia Regional e Desenho, encarregar-se-á da elaboração do
Atlas Corográfico Municipal, que conterá a descrição sistemática das divisas
intermunicipais e interdistritais da reunião e exame do material de execução do
decreto-lei nacional n. 311 , que dispõe sôbre a divisão territorial do país, colaborará
com as administrações das Unidades Federadas no preparo das respectivas cartas
regionais; (IBGE, 1939c, p. 112 . Grifos nossos. ( $^{68}$

Assim, em termos hierárquicos, o Recenseamento de 1940 era a atividade de maior importância cujos preparativos se desdobravam em eixos de trabalho de natureza essencialmente cartográfica sob responsabilidade do CNG. Dentre estes, a atualização da Carta do Brasil ao milionésimo pode ser considerada a mais importante, por demandar as demais atividades, a saber, a Campanha das Coordenadas das sedes dos municípios brasileiros e a confecção de mapas municipais, estes sob responsabilidade dos próprios municípios, coordenados e auxiliados pelo Conselho. A delimitação precisa de limites, tanto internacionais quanto interestaduais, apesar dos levantamentos específicos para este fim também realizados pelo CNG, surgiria como um subproduto da atualização da Carta do Brasil ao milionésimo e era do maior interesse do Estado, como maneira de solucionar históricas e recorrentes disputas entre proprietários de terras.

A primeira publicação de natureza cartográfica publicada na RBG surgiu já no número inaugural, denominada "Mapas Municipais" "99, sob autoria da Secretaria Geral do CNG. Tratase da divulgação das consequências práticas decorrentes da publicação do famoso Decreto-Lei n. 311, de 2 de março de 1938, também conhecida como "Lei Geográfica do Estado Novo" ou "Lei Geográfica Nacional". "Instituindo uma sistemática para a divisão territorial do país, a referida lei nacional impõe medidas de grande alcance para a Geografia e para a Cartografia brasileiras." (IBGE, 1939b, p. 80)

A Lei, a despeito de seu caráter autoritário comum ao Estado Novo, impôs aos municípios uma ampla gama de padronizações efetivamente fundamentais para a posterior

${ }^{68}$ IBGE. Instalação do Serviço de Coordenação Geográfica. Revista Brasileira de Geografia, v. 1, n. 2, 1939, p. 112. (Noticiário.)

${ }^{69}$ Cf. IBGE. Mapas municipais. Revista Brasileira de Geografia, v. 1, n. 1, 1939, p. 80-94. (Comentários.) 
coordenação de trabalhos que tivessem por base o território nacional. Chama a atenção o curto prazo para a execução de trabalhos cartográficos de grande complexidade, bem como a punição aos municípios que não cumprirem a meta, previstos no Art. 13 da referida lei:

Art. 13. Dentro do prazo de um ano, contado da data desta lei, ou da respectiva instalação, se ulterior, os municípios depositarão na Secretaria do Diretório Regional de Geografia, em duas vias autenticadas, o mapa do seu território.

$\S 1^{\circ} \mathrm{O}$ mapa a que se refere este artigo, ainda quando levantado de modo rudimentar, deverá satisfazer os requisitos mínimos fixados pelo Conselho Nacional de Geografia.

$\S 2^{\circ} \mathrm{O}$ município que não der cumprimento ao disposto neste artigo terá cassada a autonomia e o seu território será anexado a um dos municípios vizinhos, ao qual fica deferido o encargo, aberto novo prazo de uma ano, com diêntica sanção. (BRASIL, $1938)^{70}$

O artigo, ainda, reproduz a Resolução n. 3 do Diretório Central do CNG, que estabelece as instruções técnicas para o cumprimento do Decreto-Lei n. 311 e discute os exemplos de coordenação executiva observados em Minas Gerais e São Paulo, que centralizaram os esforços a partir de uma coordenação de âmbito estadual. Vale observar que todos os 1574 municípios brasileiros cumpriram o prazo estabelecido.

\begin{abstract}
Graças à firmeza com que o Presidente da República apoiou a ação do Instituto Brasileiro de Geografia e Estatística, e para o desaponto dos que não acreditavam no êxito da operação geográfica-administrativa de tão larga envergadura, todo o território nacional foi levantado, com exatidão compatível com os processos de levantamento expedito, permitindo o conhecimento da linha de contôrno de cada Município, as divisas inter-distritais, as sedes municipais, as principais elevações, o desenvolvimento dos maiores cursos d'água, as estradas de rodagens, e as mais importantes fazendas, engenhos e estâncias. (IBGE, 1940b, p. 248) ${ }^{71}$
\end{abstract}

Já a campanha de levantamento das coordenadas geográficas das sedes dos municípios brasileiros, não prevista inicialmente, surgiu como possibilidade de aumentar a qualidade dos mapas municipais e da própria Carta do Brasil ao milionésimo, além de agregar informação geográfica sobre o território nacional, ainda quantitativamente pouco expressiva. (IBGE, 1939 d, p. 130 $)^{72}$

70 Disponível em: <http://www2.camara.leg.br/legin/fed/declei/1930-1939/decreto-lei-311-2-marco-1938351501-publicacaooriginal-1-pe.html> Acesso em 10 de janeiro de 2016.

71 IBGE. Exposição de mapas municipais. Revista Brasileira de Geografia, v. 2, n. 2, 1940, p. $248-9$. (Comentários.) A Redação da RBG transcreveu algumas passagens do discurso proferido pelo Presidente do IBGE José Carlos de Macedo Soares durante a Hora do Brasil, no qual ele inaugura a exposição dos mapas municipais que ocorreriam simultaneamente em cada sede municipal. Chama a atenção o fato de que, para Macedo Soares, o período autoritário do governo de Getúlio Vargas se justificaria apenas pelo sucesso da empreitada. Segundo o texto da Redação da RBG, "Essas cerimônias comprovam realmente a vitória da mais extensa e da mais importante iniciativa do atual Govêrno da República, vitória que não poderia ter sido alcançada na vigência da autonomia dos Estados, e da autonomia dos Municípios.” (p. 248)

${ }^{72}$ IBGE. Uma campanha de levantamento de coordenadas geográficas. Revista Brasileira de Geografia, v. 1, n. 3, 1939, p. 130-132. (Noticiário.) 
A campanha foi realizada por engenheiros da administração estadual indicados para tal atividade e coordenados e preparados tecnicamente pelo $\mathrm{CNG}$, sob direção do Prof. Alírio de Matos. Frente à oportunidade de se ter técnicos qualificados visitando lugares ainda remotos em relação à administração federal, foi solicitado que estes "viajantes exploradores, cujos relatórios parciais constituirão apreciável contingente de informações valiosíssimas”, realizassem descrições relativas à fisiografia e à geografia humana, bem como coletassem amostras de rochas dos caminhos percorridos. (IBGE, 1940c, p. 268) ${ }^{73}$

A atualização da Carta Geral do Brasil ao milionésimo constituía-se, pois, empreendimento maior do Conselho e mobilizava frentes de trabalho diversas. Além das citadas, pode-se citar, ainda, uma vasta pesquisa de gabinete em busca de cartas topográficas e plantas cadastrais, em repartições federais, estaduais e municipais, atividade possibilitada pela estrutura administrativa do IBGE que articulava as três esferas de poder. Até mesmo a impressão das folhas da nova Carta Geral exigiu esforços específicos neste sentido. ${ }^{74}$

Isto posto, nota-se como do aspecto superficial da cartografia do IBGE, restrita à sua própria natureza técnica, emergiu um de seus aspectos profundos, a constituição de um campo de atuação para geógrafos profissionais. Legitimada pela tradição do que se entende por labor geográfico e pelas demandas estatais, os simpatizantes da Geografia fortaleceram a posição do Conselho Nacional de Geografia dentro do IBGE e possibilitaram a constituição de um notável aparelho de trabalho e pesquisa que, a despeito de atenderem à entidade que o financiou, proporcionaram o desenvolvimento epistemológico do saber geográfico.

Vale reiterar que a ala geográfica do IHGB já canalizava há décadas questões de ampla repercussão da agenda governamental, não sendo, pois, novidade que a ciência geográfica se detivesse sobre assuntos de interesse do Estado. A questão cartográfica, contudo, embora fonte de preocupações de longa data, estava diluía em múltiplas e fragmentadas iniciativas, era imprecisa e sem sistematização técnica, via de regra não contando com trabalhos de campo. Foi precisamente este campo de atuação que o discurso de autoridade da chamada ciência geográfica moderna reclamou para si.

\footnotetext{
${ }^{73}$ IBGE. Campanha de coordenadas geográficas. Revista Brasileira de Geografia, v. 2, n. 2, 1940, p. 268-269. (Noticiário.) A respeito desta Campanha, cf. também: RBG v. 2, n. 3, 1940, p. 489; RBG v. 3, n. 1, 1941, p. 171175; RBG v. 3, n. 2, 1941, p. 454-456; RBG v. 3, n. 3, 1941, p. 738-740; RBG v. 3, n. 4, 1941, p. 907-909; RBG v. 4, n. 1, 1942, p. 201-203; RBG v. 4, n. 2, 1942, p. 429-432.

${ }^{74}$ Cf., dentre outros materiais, IBGE. Carta geográfica do Brasil ao milionésimo. Revista Brasileira de Geografia, v. 4, n. 2, 1942, p. 413-418. (Noticiário.) Ver também: RBG v. 1, n. 3, 1939, p. 133; RBG v. 4, n. 4, $1942,885-891$.
} 


\subsubsection{As contribuições de Francis Ruellan}

Em meio a trabalhos de natureza cartográfica, destacam-se as publicações e a atuação profissional do geógrafo francês discípulo de Emmanuel de Martonne e especializado em Geomorfologia, Francis Ruellan. Enviado em 1940 pela França ao Rio de Janeiro como adido militar na América do Sul e Caribe, em decorrência da guerra "foi desmobilizado pelo Exército, em 1941, aceitando o cargo de consultor técnico do Conselho Nacional de Geografia e de professor de Geografia da Faculdade Nacional de Filosofia. Esteve nessas duas instituições até o final de ano de 1956." (MACHADO, 2009, p. 132)

Ruellan desenvolveu o ensino e a pesquisa em articulação com as investigações que dirigia no CNG e proporcionou a aproximação de estudantes de Geografia da Universidade do Brasil com o Conselho, “criando espaços para as carreiras de geógrafos, até então inexistentes no Brasil." (MACHAdO, 2009, p. 133) Em um grau muito mais elevado do que em São Paulo, Ruellan diluiu a distância entre o universo acadêmico e a demanda estatal. No caso paulista, além do projeto universitário propositalmente distanciar-se das ambições de âmbito federal, a captação de verbas públicas demonstrou-se muito mais difícil.

A posição de destaque da Geografia Física na promoção do labor empírico-descritivo assumido pela Geografia do CNG até o fim dos anos 1950 advém em grande medida da atuante posição de Ruellan na valorização institucional e pedagógica do trabalho e das modernas técnicas de campo, além da importância que a geomorfologia assumiria naquele momento histórico. A perspectiva ideológica da neutralidade científica proporcionada pelas novas técnicas de mensuração e coleta fortalecia a posição dos geógrafos enquanto articuladores de diversas especialidades e, frente à necessidade de levantamento de recursos naturais pelo Estado, Ruellan soube atuar de forma decisiva em benefício da Geografia neste contexto de grande proximidade com o gabinete presidencial. (GEIGER, 1988, p. 63)

\footnotetext{
Outra atividade importante de Francis Ruellan foi a organização de trabalhos de campo que permitiram acumular conhecimento empírico sobre o território brasileiro e sua ocupação. Esse levantamento foi fundamental para o grupo de geógrafos do Rio de Janeiro e para a construção do pensamento sobre o Brasil em termos de grandes conjuntos geográficos, o que, sem dúvida, era essencial para um país muito extenso e pouco conhecido geograficamente. (MACHADO, 2009, p. 133-134)
}

Sua atuação como formador de escola no Brasil pode ser comparada, talvez, unicamente com a de Pierre Monbeig em São Paulo. (AlmeidA, 2000) As grandiosas e custosas excursões promovidas pelo geomorfólogo francês, bancadas em grande medida em virtude da aproximação entre IBGE e Universidade do Brasil, eram consideradas verdadeiros cursos especiais, de elevada exigência física e intelectual. (GEIGER, 1988; MACHADO, 2009) 
Dentre seus trabalhos publicados na RBG, três deles (1943a; 1943b; 1944) versam sobre método (ou, mais precisamente, sobre metodologia) e práticas de pesquisa em Geografia, numa clara perspectiva pedagógica. Em determinadas passagens, suas proposições apelam para a sensibilidade do pesquisador, movimento observado em diversas publicações do período que impõe à ciência geográfica um grande desafio em termos de método:

É este trabalho, no terreno, que constitui a pesquisa geográfica por excelência. O geógrafo deve integrar-se, fundir-se na paisagem para observá-la nos seus conjuntos como nos seus pormenores, para senti-la e compreendê-la. (RUELLAN, 1943a, p. 55)

Apesar de pouco avançar neste campo, as páginas explicitam com nitidez o pensamento e a prática geográficas do período. O autor destaca princípios geográficos tais como descrição, localização, extensão, distribuição e correlação. Em relação ao primeiro, por exemplo, aproxima-se de proposições de Pierre Monbeig:

Os fenômenos físicos e humanos devem ser apresentados nos seus aspectos complexos, sem serem isolados do meio em que foram observados. Um trabalho deixa de ser geográfico quando isola os fatos da paisagem, que constitui o meio complexo em que são observados. (RUELLAN, 1943b, p. 559. Grifo do autor.)

A pesquisa idiográfica é a base de todas as regras enunciadas:

Todas as regras formuladas acima se aplicam igualmente à Geografia regional, a diferença provindo antes de uma questão de escala do que de uma questão de método, mas a originalidade da Geografia regional provem sobretudo dela considerar uma porção do espaço terrestre como uma individualidade cujos caracteres procura definir. (RUELLAN, 1943b, p. 562. Grifo do autor.)

$\mathrm{O}$ autor exalta a importância das interpretações em fase posterior às descrições, mas ressalta a prudência com que se deve conduzir a Geografia Geral:

este trabalho de crítica científica deve ser conduzido com uma perfeita objetividade e uma grande prudência. Não se deve perder de vista principalmente que a geografia geral é uma ciência nova, cujos primeiros mestres foram os europeus e os americanos do norte, que tiveram a tendência de generalizar o que observaram no meio em que viveram, mas que certamente se enriquecerá com observações cada vez mais numerosas, feitas em outras regiões do globo em que os fatores que formam o complexo geográfico variam segundo leis que não são sempre perfeitamente conhecidas. (RUELLAN, 1943a, p. 52-53)

Ruellan (1943b, p. 563) sugere, ainda, que deve se rejeitar os planos tradicionais de redação "em que os fatos se sucedem numa ordem lógica variável: situação, geologia, relevo, clima, como se se tratasse de esvaziar o conteúdo de gavetas, sem cuidado de coordenação", pois "mascaram os caracteres fundamentais do assunto tratado." Em termos de pesquisa de campo de curta duração, contudo, Ruellan (1944a, p. 36-40) sugere um itinerário definido "durante o qual todos os problemas se apresentam em conjunto, o que requer uma grande experiência." A sequência de investigação proposta pelo autor - formas de relevo, 
localização, relação entre relevo e estrutura, climatologia, hidrografia, biogeografia e geografia humana - apesar de privilegiar aspectos do âmbito geomorfológico, parece ser bastante representativa, junto ao modelo de exposição por ele criticado, do modus operandi da Geografia praticada no período.

Embora as publicações do geógrafo francês estejam permeadas de linguagem cartográfica, merece destaque um trabalho de sua autoria, apresentado na II Reunião Panamericana de Consulta sobre Geografia e Cartografia, no qual propõe a "carta estereográfica em diagrama perspectivo de uma rede de cortes retangulares". Tal forma de representar o relevo "presta os maiores serviços nos estudos geomorfológicos, pois com seu auxilio se podem encontrar as relações entre as formas do terreno, a estrutura e os depósitos superficiais nas três dimensões." (RUELLAN, 1944b, p. 225) O modelo de representação impressiona pela complexidade e indica o elevado nível propositivo de Ruellan e da Geografia que se praticava junto ao CNG e à Universidade do Brasil. (vide IMAGEM 1)

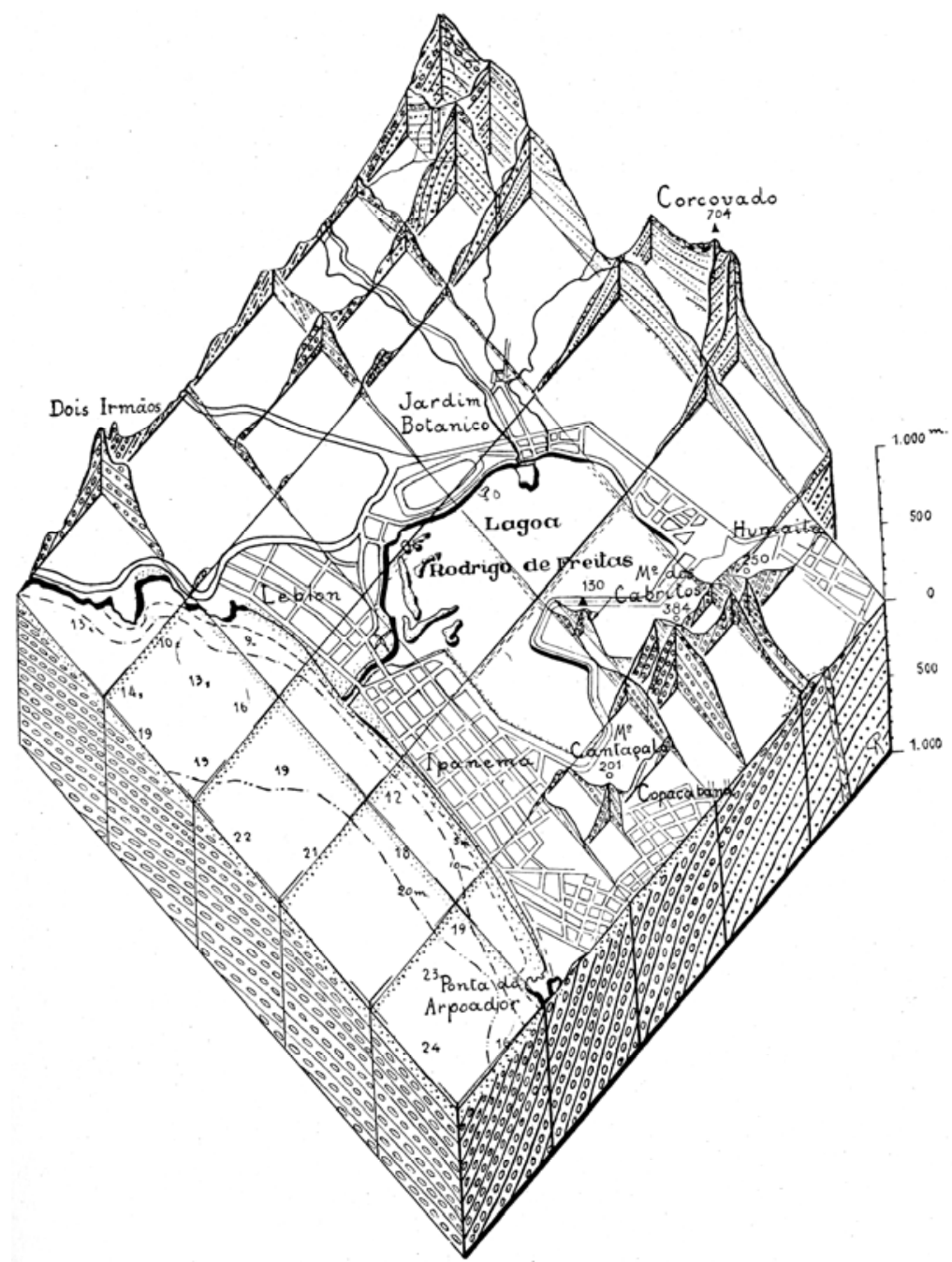

IMAGEM 1 - Carta estereográfica em diagrama perspectiva de uma rede de cortes retangulares. "Pequena parte do diagrama perspectivo do Rio de Janeiro e arredores (ângulo SE da folha n 13 do Pico da Tijuca e ângulo SW da folha no 17 do Pão de Açúcar” (RUELLAN, 1944b, p. 223) 
Ao final da comunicação, Ruellan argumenta em favor da utilidade prática da proposta:

Sabemos que, na localização das minas, por exemplo, a maior dificuldade consiste em seguir a direção dos filões e a carta estereográfica pode ser aí de grande utilidade. [...] Outra aplicação muito prática do sistema é a construção de estradas de rodagem ou de ferro. Mediante esse sistema, obtém-se um corte do terreno por onde deve passar a estrada e torna-se fácil estudar a influência da natureza e da inclinação das camadas sobre o perfil do corte da estrada. [...] As modificações do fundo do mar ou de um rio podem também ser seguidas, de modo a preparar os trabalhos destinados a corrigir as erosões e as acumulações para facilitar a navegação. (RUELLAN, 1944b, p. 227-229)

Sua proposta de representação do relevo acabou não sendo adotada, possivelmente, devido à complexidade de elaboração, em um período anterior à informática. Mas o autor a utiliza em um de seus trabalhos mais importantes (vide IMAGEM 2), Evolução Geomorfológica da Baía de Guanabara e das Regiões Vizinhas (1944c), artigo que "é um dos mais completos e detalhados trabalhos sobre os processos geomorfológicos formadores da Serra do Mar e das planícies litorâneas que cercam a região da baía de Guanabara.” (ALMEIDA, 2000, p. 92)

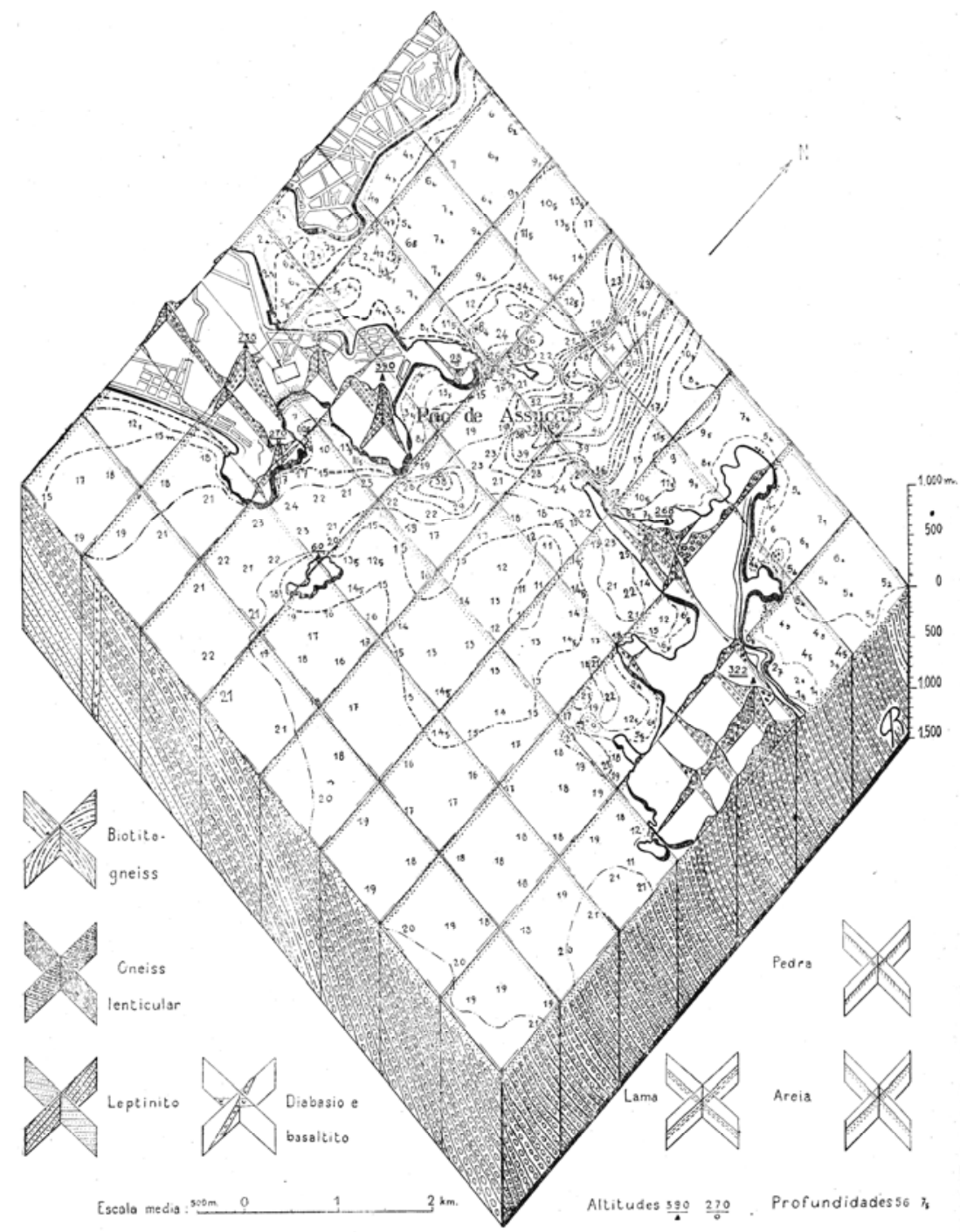

IMAGEM 2 - "Fragmento da carta estereográfica em diagrama perspectivo de uma rede de cortes retangulares do Rio de Janeiro e regiões vizinhas" (RUELLAN, 1944c, p. 478) 


\subsubsection{Da Cartografia à Política - outra faceta geográfica}

Como já apontado, Mário Augusto Teixeira de Freitas, então diretor do Serviço de Estatística Geral de Minas Gerais, já na década de 1920 realizou uma bem sucedida unificação do serviço estatístico mineiro ao serviço geográfico, articulando a estatística à cartografia em um serviço de estatística territorial. Quando convidado pelo ministro da Educação, no início da década de 1930, para pensar o serviço estatístico em âmbito nacional, propôs um serviço estatístico-cartográfico similar, o Instituto Nacional de Estatística e Cartografia. Rechaçada por alguns membros da comissão designada para avaliar sua proposta, a cartografia foi incluída por Teixeira de Freitas na Seção de Estatística Territorial, da Diretoria de Estatística da Produção, do Ministério da Agricultura, em 1934, como manobra para inclui-la na agenda de âmbito federal. Esta seção seria, assim, o embrião do CNG.

Este movimento, institucional ou motivado por interesses pessoais, na luta pela consolidação de um campo profissional, já está suficientemente claro. ${ }^{75}$ Devemos, ainda, contudo, fazer referência ao segundo aspecto profundo da cartografia praticada pelos colaboradores do $\mathrm{CNG}$, qual seja, a própria estruturação epistemológica da moderna ciência geográfica brasileira.

Como já afirmado, a participação da ciência geográfica junto às ações de Estado lideradas por Vargas, em que pese os esforços concretos da comunidade simpática à Geografia, pouco tem de acidental ou contingente. De fato, é de se questionar a pureza acadêmica da epistemologia geográfica, supostamente desvinculada do âmbito da Política, bem como o próprio epíteto "moderna" da prática geográfica vivenciada no Brasil a partir dos anos de 1930, seja nas Universidades, seja no CNG.

A assunção da natureza intrinsecamente política da Geografia, que nem por isso deixa de ser científica, fornece um caminho lógico para a interpretação conjunta dos temas presentes de maneira mais recorrente na RBG até 1956, bem como uma possível relação existente entre estes materiais e as teses defendidas junto ao Departamento de Geografia da USP, no mesmo período. Tal assunção, mais do que formular uma proposição que serve de premissa a um raciocínio, tem mesmo a força de questionar a corrente historiográfica

\footnotetext{
${ }^{75}$ De fato, a história do pensamento geográfico brasileiro contada pelo viés da história institucional ou pelo viés de uma sociologia da constituição do campo de atuação não parece ser comum. Há um excesso de referências aos mestres fundadores da ciência geográfica, mas pouca atenção ao movimento político travado entre os principais indivíduos que efetivamente construíram a ciência geográfica brasileira, com o advento das Universidades e do CNG. Assim, quando falo em suficiência de referências à questão política em torno da constituição de um campo para geógrafos profissionais no seio do Estado, restrinjo-me apenas aos objetivos introdutórios propostos por este trabalho.
} 
hegemônica da Geografia, que tem por base, primeiro, um debate fixado majoritariamente sobre os conceitos e, segundo, a negação da dimensão política da corrente geográfica francesa largamente adotada no Brasil.

A este respeito, o ensaio de Ribeiro $(2015)^{76}$ está centrado na crítica à resistência da corrente majoritária da historiografia geográfica - ancorada na separação entre e ciência e política ou num visível descuido em relação aos fundamentos políticos da disciplina - em assumir que a história da Geografia foi forjada na esfera política operada pelo status quo. (RiBeIRO, 2015, p. 48/51). Para tanto, argumenta o autor que a Geografia, através da Cartografia, além de criar uma imagem de mundo como algo "incontornavelmente fronteiriço", acredita naquilo que inventa e, mais, convence, em termos universais, que a concepção de mundo que a gerou é única, coerente e precisa. (RIBEIRO, 2015, p. 41-42) Segundo o autor, o "geógrafo incumbiu-se de consagrar a imagem de um mundo fronteiriço e territorial, incluídas aqui as tão conhecidas - e celebradas, dependendo da conjuntura personagens do estrangeiro, do conquistador, do patriota, do nacionalista", em um movimento em que "a linguagem cartográfica é uma linguagem-força que sufocou outras representações espaciais.” (RIBEIRO, 2015, p. 42) De sua argumentação, pode-se depreender que os conceitos de fronteira e território seriam, pois, elementos constitutivos tanto da ciência geográfica quanto da geografia imposta ao mundo.

A razão instrumental da ciência moderna teria tornado verdadeira uma projeção do mundo em favor dos interesses imperialistas europeus, num movimento de homogeneização e hierarquização que "legitima toda e qualquer intervenção de cima para baixo, pois nele os sujeitos tornam-se meras coordenadas geográficas, objetos de uma antropologia, sociologia, história e geografia obedientes à lógica da eficiência, da maximização e da racionalização instrumental do mundo.” (RIBEIRO, 2015, p. 43)

Assim, a tese de Ribeiro (2015, p. 44) é a de que "a moderna geografia universitária já surge geopolítica, tendo como fundamento a edificação de fronteiras" (grifos do autor) não apenas no problemático contexto de formação nacional europeia, mas na justificação do expansionismo territorial destes Estados para além de seus domínios imediatos.

"Nesta conjuntura, as cartas geográficas eram preciosas não apenas por serem estratagemas de controle e dominação, mas sim [...] porque tentavam esconder as fragilidades dos conquistadores." As fronteiras por ela erigidas ao mesmo tempo em que viabilizaram o

\footnotetext{
${ }^{76}$ Fortuita foi minha participação no XI Encontro da Anpege, ocorrido em outubro de 2015, em Presidente Prudente. Devido, em parte, ao pequeno número de participantes no grupo de trabalho (GT) "História da Cartografia", o artigo por mim apresentado foi objeto de amplo debate pelos coordenadores do GT, permitindome reforçar algumas reflexões e entrar em contato com contribuições como a de Ribeiro (2015).
} 
expansionismo europeu, justificam até hoje as respostas violentas, xenofóbicas e conservadoras aos problemas criados por elas. Assim, "a geografia participa ativamente da elaboração de nosso imago mundi, mas como mito: o mito do espaço moderno. Não se trata apenas do Estado Nacional Territorial, mas de algo muito além dele. Criou-se uma cultura da fronteira no mundo ocidental.” (RIBEIRO, 2015, p. 47-48)

A argumentação do autor segue no sentido de questionar as posturas de desconsideração da obra de Elisée Reclus e de excessiva repreensão a Ratzel, cujos fundamentos são praticamente o mesmo: "ambos não dissociavam a geografia da política e explicitavam tal postura - algo que, do ponto de vista da epistemologia moderna, afastava o pensamento da 'cientificidade'." (RIBEIRO, 2015, p. 48) O autor questiona, ainda, a "pura” cientificidade da corrente francesa de pensamento geográfico, na medida em que todos os seus maiores nomes "não só eram partidários do colonialismo como emprestaram sua expertise ao governo francês no escrutínio e na reorganização das fronteiras territoriais durante e após a Primeira Guerra Mundial", fato também convenientemente desconsiderado pela historiografia hegemônica.

Quando voltamos os olhos para os materiais publicados na RBG sob a entrada GEOGRAFIA POLÍTICA, entre 1939 e 1956, parece não haver dúvida quanto à coerência entre as possíveis contribuições da ciência geográfica às demandas forjadas no contexto políticoeconômico dentro do qual ela adquiriu importância, bem como quanto à forma como o pensamento geográfico apreendia a dimensão geográfica da realidade, tradição de pensamento cujo fortalecimento também deve ao contexto de uma ciência amadurecida no seio do Estado.

\subsubsection{Geografia Política}

A análise superficial dos materiais publicados na RBG sob a entrada GEOGRAFIA POLÍTICA revelam duas claras linhas temáticas que se sucedem. Entre 1939 e 1945, a questão das fronteiras mereceu grande destaque, articulando-se a ela o tema da divisão regional. Para se ter uma ideia da importância da questão das fronteiras nos primeiros anos da Revista, se se consideramos a classificação dos materiais proposta pela Biblioteca Geral do IBGE, materiais sob a entrada FRONTEIRA registram 16 aparições até 1983, sendo 15 delas até $1956 .{ }^{77}$

\footnotetext{
77 Ainda segundo a classificação dos materiais a partir dos critérios da Biblioteca Geral do IBGE, 9 de um total de 13 materiais publicados sob a entrada GEOPOLíTICA foram publicados até 1956. Não conseguimos localizar, contudo, um critério claro para a classificação destes materiais segundo esta entrada.
} 
Já entre 1946 e 1956 a temática que dominou os trabalhos de Geografia Política foi a da transferência da capital federal para o Planalto Central brasileiro. Dos 12 materiais de Geografia Política publicados na RBG ao longo de pouco mais de uma década, seis versavam sobre a transferência da capital. Nota-se que, de fato, foram poucos materiais publicados no âmbito da Geografia Política, frente ao volume de edições da RBG. A transferência da capital federal dominou as preocupações dos geógrafos do IBGE, porém de maneira bastante concentrada temporalmente, em decorrência de dispositivos presentes na nova Constituição de 1946. Aparentemente, a quantidade de materiais publicados não reflete o intenso debate acerca da nova capital federal, cujos materiais resultantes provavelmente renderam publicações especiais.

Um fato torna-se especialmente válido quando se analisa os materiais sob a entrada GEOGRAFIA POLíTICA. Nota-se uma razoável superficialidade no conteúdo dos materiais, embora não extensível aos materiais dedicados à divisão regional do Brasil, revelando-se a Revista um meio de divulgação para um público amplo, além de um espaço privilegiado de debates para um campo específico de saber. A transferência da capital federal para o Planalto Central, por exemplo, relevou-se uma atribuição por excelência do campo geográfico, porém, com uma incomum agilidade, em pouco mais de dois anos já havia sido publicado o relatório final sobre o tema, cabendo à RBG tão-somente a divulgação dos aspectos gerais do problema.

O início da década de 1940 foi marcada pela importância adquirida pela nova divisão regional brasileira, assunto que passou a dominar as páginas de Geografia Política da RBG. Três artigos, sob autoria de Segadas Viana (1940), Soares Guimarães (1941) e Teixeira de Freitas (1941) ${ }^{78}$ destacam-se, por apontarem, no conjunto, os inconvenientes da então divisão territorial brasileira e por enxergarem o momento político propício para a imposição de uma nova divisão. Guimarães expressa perplexidade ao descrever historicamente as diversas propostas de divisão territorial propostas ao Brasil e a elevada divergência entre elas. Os autores tendem a enxergar nos elementos naturais os fatores de neutralidade suficientes para a proposição de uma divisão sobre interesses políticos estaduais e regionais.

Podemos notar, sem dificuldade, que todos os temas de maior destaque publicados sob a entrada GEOGRAFIA POLÍTICA estão intimamente relacionados à questão cartográfica nacional. Mais do que isso - e esta é uma característica cuja importância deve ser ressaltada -, as publicações versam cartograficamente sobre o território nacional tendo como cerne, além da

\footnotetext{
${ }^{78}$ Frente à importância que a temática adquiriu para a administração federal, em especial devido ao conflito com os poderes locais, teria sido válido uma análise aprofundada restrita a estes materiais e outros, complementares.
} 
questão especificamente política do domínio territorial pelo Estado, a questão do desenvolvimento econômico. As questões, assim, relativas a demografia, desenvolvimento de uma malha terrestre de transporte, projetos de colonização, agricultura e pedologia estabelecem, no plano teórico, uma trama de relações animada pelo objeto central de preocupações, o desenvolvimento econômico do territorial nacional.

O fato mesmo é que as subáreas de pesquisa geográfica de maior destaque da Revista até 1956 (cf. Tabela 1) refletem a preocupação econômica subjacente ao projeto nacional iniciado por Getúlio Vargas. A permanente teia relacional entre os temas mais populares, que inclusive nos impede de propor uma classificação temática precisa dos materiais publicados, é uma demanda imposta pela própria realidade territorial e histórica brasileira, tornando trabalhos de Geografia Regional, Geografia Econômica ou Pedologia, por exemplo, exemplares de uma ciência com preocupações essencialmente geopolíticas.

Destituir-se-ia de sentido ou se tornaria enfadonha a análise epistemológica da ciência geográfica praticada pelo IBGE se se desconsiderasse o propósito dominante que animou os estudos geográficos naquele período. A afirmação do propósito estatal de lógica econômica que fomentou o desenvolvimento da ciência geográfica, porém, embora seja uma das principais conclusões a que se pode chegar com a presente pesquisa, possui desdobramentos que se situam além de nossas possibilidades atuais de análise. Por um lado, parece haver constrangimento em afirmá-la. Por outro, as críticas a ela endereçadas parecem atacar não apenas a histórica filiação política da disciplina, como também a estrutura epistemológica erigida no seio da relação ciência geográfica-Estado. Há, ainda, como desdobramento dessa afirmação, a dificuldade de se identificar o conteúdo da realidade sobre o qual se debruça a ciência geográfica, centrando-se o debate, antes, sobre as práticas geográficas.

Em relação, especificamente, ao material publicado sob a entrada GEOGRAFIA POLÍTICA, aqueles referentes à questão da fronteira são, via de regra, histórico-descritivos. Tratam do processo de delimitação, no plano diplomático, dos limites internacionais brasileiros ${ }^{79} \mathrm{e}$ procuram descrever a importância e a dificuldade de se traçar em superfície as linhas demarcatórias em regiões ainda amplamente desconhecidas. Por ser a região que recebia, naquele momento, maior atenção do Estado em termos de delimitação de fronteira, o Norte do país centralizou a maior parte das publicações.

\footnotetext{
79 Pereira (1941), p. ex., lista todos os Tratados que permitiram fixar os limites internacionais com precisão. cf. PereIRA, Renato Rodrigues. Limites. Revista Brasileira de Geografia, v. 3, n. 1, 1941, p. 114-124. (Inquéritos Geográficos.)
} 
A tônica que marca os materiais revela que os geógrafos participaram pouco, diretamente, do trabalho àquela altura prático de delimitação em solo dos limites internacionais. ${ }^{80}$ Quanto a este aspecto, Pereira (1941) explica que o simples estabelecimento de limites não é suficiente para a garantia da zona fronteiriça. É necessário que o Estado tenha acesso a elas, através de uma malha de transportes compatível. O autor aponta a possibilidade de o CNG organizar comissões de reconhecimento topográfico apoiado em coordenadas geográficas de zonas fronteiriças. Salienta, contudo, a conveniência de tais serviços serem executados pelo Exército, com concurso de especialistas civis, tendo em vista "o estado atual de muitas de nossas fronteiras". (PereIRA, 1941, p. 122) De fato, segundo Pereira (1945) e Correia Filho (1945), por sua natureza e periculosidade, o serviço em campo foi realizado via de regra por militares ligados às Forças Armadas e ao Ministério das Relações Exteriores. ${ }^{81}$ Quanto à questão no plano diplomático, ambos os autores identificam os conhecimentos geográficos do barão de Rio Branco como decisivos para os consideráveis ganhos territoriais brasileiros, por vias pacíficas.

Por conhecimento geográfico ambos os autores entendem os "fatos geográficos" que compõem a geografia da região fronteiriça. Dada a natureza da geografia regional e os elementos geográficos considerados nos acordos internacionais para a fixação das divisas internacionais, a profunda erudição cartográfica e historiográfica acerca da formação territorial do Brasil apresentado por Rio Branco se manifestou na forma de vasto domínio sobre a hidrografia e topografia da região amazônica, superior ao dos especialistas das demais nações fronteiriças. ${ }^{82}$

Também Reis e Oliveira (1944) discorrem sobre o trabalho de delimitação dos limites. Os autores fazem referência a uma série de pesquisadores cuja contribuição, individualmente ou junto a comissões nomeadas pelo Governo, sem o alarde e a luxuosidade das expedições europeias e norte-americanas, "já trouxe novidades interessantíssimas à revelação geográfica do continente." (REIS e OliveIRA, 1944, p. 245) Assim esclarecem a autoria dos trabalhos realizados então:

\footnotetext{
${ }^{80}$ O exame minucioso da Seção "Noticiário", bem como das publicações do Boletim Geográfico, pode indicar o contrário. Não realizamos uma pesquisa exaustiva a este respeito.

${ }^{81}$ Questão pouco considerada é a periculosidade dos serviços de reconhecimento territorial realizados pelos técnicos do IBGE. É o caso de Roberto Galvão, autor que citaremos adiante, que morreu na realização do serviço de levantamento geomorfológico da calha do rio Tocantins para determinação da localização da futura Usina Hidrelétrica de Tucuruí. Sua embarcação bateu em uma rocha submersa e seu corpo, lançado nas águas turbulentas do rio, foi encontrado apenas quatro dias depois. (Cf. ALMEIDA, 2000, p. 210-211)

82 "E assim, ao gizar o contôrno do Brasil, de harmonia com a missão iniciada por dois pleitos vitoriosos, atuou não somente como geógrafo, possuidor dos melhores conhecimentos acêrca do território nacional, mas também com idéias de geopolítico, ao barrar no Acre a entrada de tendencioso organismo colonizador e a permitir no extremo sulino o condomínio dos confrontantes." (CORREIA Filho, 1945, p. 298)
} 
$\mathrm{Na}$ atualidade, um dos serviços que tem prestado maiores benefícios à revolução geográfica continental como contribuição brasileira, é o que está a cargo da Comissão Brasileira Demarcadora de Limites $-1^{\mathrm{a}}$ Divisão ${ }^{83}$, orientada e dirigida pelo capitão de mar e guerra Brás Dias de Aguiar, sertanista consumado e um dos brasileiros cuja soma de serviços a sua pátria lhe conferem títulos ainda há bem pouco tempo proporcionados por S. Excia. o Sr. Presidente Getúlio Vargas. (REIS e OLIVEIRA, 1944, p. 246)

O referido Comandante Brás Dias de Aguiar publicou no número seguinte da RBG um artigo intitulado Geografia amazônica: nas fronteiras do $N_{0 r t e}{ }^{84}$, no qual vê-se com facilidade que o estabelecimento em terra de marcos que identificam os limites já estabelecidos diplomaticamente baseava-se no complexo reconhecimento topográfico e hidrográfico de lugares que impunham enormes dificuldades de penetração. O autor faz "um resumo dos [serviços] que foram levados a efeito nestes últimos quatro anos nos rios Mucajaí, Catrimani, Demeni e cabeceiras do Orinoco.” (AGUiAR, 1944, p. 329) As páginas são fortemente descritivas, com referência a latitudes e longitudes, altitudes rede de drenagem, picos e serras, formações vegetais, populações indígenas e dificuldades de viagem diversas.

Em decorrência do centenário de nascimento do barão de Rio Branco, a edição n. 2 do volume 7 da RBG publicou dois artigos sobre o chanceler, além de uma nota na Seção Noticiário, na qual se descreve as solenidades oficiais e se lista a bibliografia publicada pelo eminente diplomata brasileiro ao longo de sua carreira.

Os materiais são de natureza historiográfica e versam sobre a diplomacia brasileira, com ênfase para a grande participação do barão de Rio Branco em torno dos acordos e tratados que estabeleceram divisas do Brasil com outros países da América do Sul. Pereira (1945), consultor técnico do Ministério das Relações Exteriores, objetivo em suas colocações, além de reproduzir passagens de diversos documentos históricos sobre o qual faz referências, assim como Correia Filho (1945), exalta o "esfôrço desenvolvido, os profundos conhecimentos históricos e geográficos revelados, [e] a paciente pesquisa e descoberta de documentos cartográficos nos arquivos do Brasil, de Portugal, da Espanha e da França” (PEREIRA, 1945, p. 196) realizada pelo barão de Rio Branco.

Desde o Tratado de Madri de 1750, envolvendo as posses coloniais de Portugal e Espanha, determinou-se que os limites internacionais "fôssem determinados pelos rios e

\footnotetext{
${ }^{83}$ Tal Comissão existe até hoje. Cf. o site oficial: $<$ http://pcdl.itamaraty.gov.br/pt-br/Main.xmll . Acesso em 08 fev. 2016.

${ }^{84}$ O autor faz referência (p. 329) a um trabalho sobre a Comissão de Limites apresentado no IX Congresso Brasileiro de Geografia, sobre o qual não encontramos registros explícitos nos Índices da RBG, mas que talvez seja o seguinte: <AGUIAR, Brás Dias de. Nas fronteiras da Venezuela e Guianas Britânica e Neerlandesa. Rio de Janeiro: SERGRAF do IBGE, 1943. 182p. (Separata dos "Anais do IX Congresso Brasileiro de Geografia". Coleção Acervo do CNG.)> Cf. AGUIAR, Comte. Brás Dias de. Geografia amazônica: nas fronteiras do Norte. Revista Brasileira de Geografia, v. 6, n. 3, 1944, p. 327-348.
} 
montes mais notáveis e conhecidos" (PEREIRA, 1945, p. 187), impondo-se, desde então, a necessidade de reconhecimento territorial da região fronteiriça. De fato, a precisa determinação do traçado e das nascentes da rede fluvial, em especial na região Norte do Brasil, adentraram o século XX e, pelo menos até o fim da década de 1940, ainda não estavam plenamente cartografados, como se pode atestar em Reis e Oliveira (1944).

Trabalhos eminentemente teóricos também foram publicados no âmbito da Geografia Política da RBG, mas dividem espaço com materiais, em geral resenhas de trabalhos estrangeiros, sobre Geopolítica. Os trabalhos teóricos sobre fronteira são marcados por forte tônica tipológica e classificatória. Antepõem-se, de certa forma, aos trabalhos escritos pelos colaboradores do CNG na medida em que estes via de regra se ocupam diretamente com o problema das fronteiras nacionais, versando pouco, em termos teóricos, sobre o tema. ${ }^{85}$

Os trabalhos sobre Geopolítica, contudo, inclusive pelo contexto da $2^{\mathrm{a}}$ Guerra Mundial, não poderiam deixar de dissertar sobre a questão das fronteiras. $\mathrm{O}$ assunto é latente, como fica claro no artigo de George Kiss:

A guerra, segundo Kjellén, é um campo experimental da geopolítica. "Os estados maiores deviam se tornar academias científicas onde êste ramo da ciência política não fôsse o menos importante". (págs. 58-59). As fronteiras, como pontos de contacto dos estados com os seus vizinhos e donde habitualmente se começa a guerra com o estrangeiro, teem sido sempre um dos problemas principais da geopolítica." (KISS, 1942, p. 860) ${ }^{86}$

Everardo Backheuser (1942) também publicou um importante artigo diferenciando Geografia Política e Geopolítica cujas considerações serão exploradas no Capítulo 3 da presente dissertação.

A partir de 1946, as publicações no âmbito da Geografia Política centram-se na questão da transferência da capital federal para o Planalto Central e são marcadas, como dissemos, pela aparição concentrada em poucos anos. O primeiro material sobre o tema foi publicado na seção Noticiário no quarto número da edição de 1946 da RBG. Exatamente três anos depois, seria publicado o último material sobre o tema, um artigo assinado por Fábio de Macedo Soares Guimarães (1949).

85 Cf. as resenhas homônimas dos trabalhos de Jacques Ancel e S. Whittemore Boggs, publicadas, respectivamente, por CARVALHO, C. M. Delgado de. Geografia das fronteiras. Revista Brasileira de Geografia, v. 1, n. 3, 1939, p. 95-110. (Comentários.); e SilvA, Moacyr M. F. Fronteiras internacionais. Revista Brasileira de Geografia, v. 3, n. 3, 1941, p. 626-635. (Comentários.)

${ }^{86}$ KISS, George. Geografia política na geopolítica; recentes tendências na Alemanha. Revista Brasileira de Geografia, v. 4, n. 4, 1942, p. 853-62. [Trad.: Germano JARDIM.] A respeito das publicações sobre Geopolítica, é digna de nota, ainda, uma tônica menos condenatória ou mesmo apologética a este ramo da Política, algo que se tornaria incomum após o término da $2^{\mathrm{a}}$ Guerra Mundial. 
Determinando o art. 4. $^{\circ}$ do Ato das Disposições Constitucionais Transitórias que "a capital da União será transferida para o planalto central do país", e sendo prefixado pelo $\S 1 .^{\circ}$ daquele artigo, o prazo para nomeação pelo Presidente da República de "uma comissão de técnicos de reconhecido valor para proceder ao estudo da localização da nova capital", o chefe do Governo em atos baixados nomeou $[. ..] \cdot$ técnicos e especialistas que passaram a integrar a Comissão Técnica para o Estudo da Localização da Nova Capital da União [...] (IBGE, 1946, p. 596)

Tal Comissão, uma vez terminado o estudo previsto, encaminharia

o mesmo ao Congresso Nacional, que, segundo o $\$ 2 .^{\circ}$ deliberará a respeito, em lei
especial, e estabelecerá o prazo para o início da delimitação da área a ser
incorporada ao domínio da União. Terminados os trabalhos demarcatórios caberá
ainda ao Congresso Nacional $\left(\$ 33^{\circ}\right.$ do mesmo artigo) resolver sôbre a data da
mudança da capital, estabelecendo o $§ 44^{\circ}$ e final que, "efetuada a transferência, o atual
Distrito Federal passará a constituir o Estado da Guanabara". (IBGE, 1946, p. 596)

Tais questões e prazos legais determinaram, em grande medida, a rapidez com que a questão foi levada a cabo, cabendo à RBG, de fato, apenas relatar um trabalho com o qual, por outro lado, a contribuição da ciência geográfica foi das mais decisivas.

Podemos afirmar que a lógica cartográfica subjacente ao raciocínio geográfico sobre a realidade, observável de maneira geral no corpo dos materiais publicados pela RBG, se explicita na localização de coisas na superfície terrestre, na maioria das vezes por um viés acadêmico-descritivo. Imbuído de um espírito de conscientizar geograficamente um Estado em pleno processo de apropriação do território sobre o qual reclamava usufruto, a Geografia do CNG por vezes ofereceu trabalhos que, de certo ponto de vista, careceriam de maior utilidade prática. ${ }^{87}$ Se este ponto de vista, conquanto não seja o único, pode ser levado em consideração, com efeito, as pesquisas para determinação da localização da nova capital federal no Planalto Central representariam o ápice da utilidade que o conhecimento geográfico pôde ter junto ao Estado. Raro foi o serviço realizado pela Geografia em que seu conhecimento específico atendeu tão bem às expectativas.

Isso porque uma das críticas que se pode fazer à Geografia do IBGE é sua filiação complacente às demandas do Estado. Considerando-se, no entanto, que o CNG foi criado com a própria finalidade de servir ao Estado, crítica mais interessante poderia ser refeita, no plano acadêmico. De fato, a análise dos materiais publicados na RBG pode indicar, como critério subjacente ao trabalho descritivo do território nacional, a indicação da localização preferencial não de todas as coisas, mas apenas daquelas possuidoras de relevância econômica sob a lógica estatal. Arriscamo-nos a afirmar que os geógrafos do CNG estariam a um passo

\footnotetext{
${ }^{87}$ De fato, esta é uma das perguntas de fundo para a qual a resposta ainda não está suficientemente dada: de que maneira o Estado, praticamente, se apropriaria dos conhecimentos geográficos produzidos pela Geografia? Seriam os trabalhos de reconhecimento territorial oferecidos pelos colaboradores do CNG realmente necessários para a execução dos projetos de apropriação econômica do Estado brasileiro?
} 
de apreender, segundo um raciocínio cartográfico, uma possível dimensão geográfica da realidade segundo a lógica do Estado capitalista. Apropriando-se dos ensinamentos adquiridos empiricamente, a Geografia do CNG poderia ter encaminhado uma crítica à apropriação do território sob lógica capitalista a partir dos princípios derivados da localização das coisas no território nacional. Tal crítica, no entanto, jamais foi realizada. Ainda maior ${ }^{88}$ teria sido a contribuição de tais geógrafos se tivessem demonstrado consciência dos processos políticos e econômicos que animam a localização do que descreviam. Mas entre estes não houve sequer a necessidade de se justificar uma empreitada de reconhecimento territorial. A justificativa, aliás, já estava dada no Decreto $\mathrm{n}^{\mathrm{o}} 1.527$ de 1937 que marcou o surgimento do CNG e sua razão prática impediu desdobramentos teóricos de maior vulto.

Já a questão da localização da nova capital federal revela que, pelo menos neste episódio, o olhar geográfico sobre a realidade extravasou os limites acadêmicos e atuou ativamente na determinação de um objeto da maior relevância para o âmbito da vida política do país. A Geografia do CNG foi além do "mero" serviço de reconhecimento territorial do país e contribuiu, mesmo, para a produção da geografia nacional, incorporando plenamente as aspirações estatais. Conforme declara Fábio de Macedo Soares Guimarães:

A escolha do local para a capital de um país é indiscutivelmente um problema político, mas os fundamentos são essencialmente geográficos. É perfeitamente correto denominá-lo um problema geopolítico. O político aponta os objetivos que se têm em vista, o geógrafo fornece-lhe os elementos em que êle se fundamentará para atingir tais objetivos. (GUIMARÃES, 1949, p. 471)

Segundo Christovam Leite de Castro, a proposta de "mudança da capital para o sertão" como maneira de estimular a ocupação efetiva do interior do país circulava desde meados do século XVIII e, embora geralmente aceita, "a ponto de Rondon dizer que a mudança da capital é o maior problema do Brasil - não tem tido até agora a correspondente movimentação prática". (CASTRO, 1946, p. 568) O nome "Brasília", por sua vez, já havia sido "sugerido em 1822 nas Côrtes de Portugal para a nova capital do Brasil.” (CASTRO, 1947, p. 281) O próprio autor afirma que "poder-se-ia dizer que no Brasil há dois problemas fundamentais, o da educação para o Brasil litorâneo e o da ocupação para o Brasil interior.” (CASTRO, 1946, p. 570)

A forma de apreensão do fundamento geográfico da realidade se apresenta de maneira particularmente cristalina nos estudos realizados pela Comissão Técnica eleita para a escolha da localização da nova capital, daí a elevada importância que julgamos ter esta atividade para a melhor compreensão dos fundamentos do saber geográfico.

\footnotetext{
${ }^{88}$ Enorme foi o trabalho realizado por esta primeira geração de geógrafos e jamais afirmaríamos o contrário.
} 
Partindo-se da distinção entre sítio e posição, colocou-se em prática o aspecto metodológico de sucessivas aproximações (CASTRO, 1946) ${ }^{89}$, de modo a se reduzir a um número viável as possibilidades em primeiro lugar de posição e, em segundo lugar, de sítio. Em sua cristalina exposição sobre sítio e posição, explica Guimarães:

Um mau sítio pode ser melhorado graças ao esfôrço humano; mas o homem nada pode quanto à posição. [...] No caso de uma capital, ainda mais se salienta a importância da posição. [...] Para o país interessa muito mais a posição em que se acha sua capital, do que o sítio. Êste interessará, certamente, de modo particular, aos habitantes da capital, mas não tanto ao conjunto da nação. [...] É no estudo da posição que mais especialmente tem o geógrafo um papel a exercer. No exame do sítio o especialista por excelência é o urbanista. Convém, entretanto, não esquecer que o urbanista, por sua vez, muito se apóia em fundamentos geográficos, e sobretudo nos ensinamentos da Geografia Urbana. (GUIMARÃES, 1949, p. 497-498)

A partir desta distinção, procedeu-se às "investigações científicas, de extensão decrescente e previsão crescente" da seguinte maneira:

$1^{\circ}$ ) conceituação científica e delimitação cartográfica do planalto central brasileiro, onde a Constituição determina que se localize a nova metrópole;

$2^{\circ}$ ) situação da faixa pioneira brasileira, onde se exerce a pressão civilizadora do leste para oeste, para que se caracterize o que se poderia chamar a região pioneira planaltina;

$3^{\circ}$ ) seleção de regiões elevadas, de modo a se identificar apenas áreas de clima ameno;

$4^{\circ}$ ) conhecimento das zonas de influência que, na região pioneira planaltina, se evidenciem mais favoráveis ao impulso civilizador da nova capital do país, a partir de estudos de distribuição dos fenômenos sociais, políticos e econômicos do Brasil;

$5^{\circ}$ ) seleção dos sítios mais favoráveis em termos ambientais à instalação de um centro urbano importante dentro das zonas de influência previamente selecionadas. (CASTRO, 1946, p. 570)

A primeira parte do artigo sob autoria de Guimarães faz um "esboço geográfico geral" de uma área não arbitrariamente considerada, "mas sim de uma verdadeira região geográfica, caracterizada por aspectos gerais quanto ao relêvo, clima, vegetação, hidrografia, ocupação

\footnotetext{
${ }^{89}$ Christovam Leite de Castro e Fábio de Macedo Soares Guimarães concentram todas as principais publicações relativas ao tema. O artigo de Guimarães é destacadamente o mais interessante. Segundo o autor: "A Comissão de Estudos sôbre a Localização da Nova Capital do Brasil organizou em 1947 duas expedições geográficas ao Planalto Central A primeira, sob a chefia do Prof. Francis Ruellan, realizou estudos de detalhes das oito zonas previamente selecionadas pela Comissão, com o objetivo de indicar 'sítios' adequados para a localização da capital. A segunda, sob a responsabilidade do autor dêste artigo e a orientação científica do Prof. Leo Waibel, estudou o Planalto Central em seu conjunto, tendo em vista o problema da 'posição' da capital e os tipos de sítios convenientes. $O$ presente artigo baseia-se nos trabalhos de campo que a segunda expedição realizou de 4 de julho a 22 de setembro de 1947, tendo percorrido cêrca de 10000 quilômetros, numa área de 200000 quilômetros quadrados." (GUIMARÃES, 1949, p. 471) Não realizamos um levantamento completo sobre o tema, mas encontramos Editoriais e Comentários relevantes nas seguintes edições mensais do Boletim Geográfico: v. 4, n. 41 , n. 45 e n. 47 ; v. 5 , n. 49 , n. 53, n. 55 , n. 56 , n. 57 e n. 58 ; e v. 6 , n. 61 . Diversos comentários são de autoria de Everardo Backheuser.
} 
humana, tipos de economia, etc." (GUIMARÃES, 1949, p. 471) O autor faz uma descrição de características gerais, expostas nesta ordem: relevo, geologia, estrutura e processos de formação; clima; hidrografia; vegetação e solos; densidade e distribuição demográfica e tipos de economia; delimitação da região. Quase todos os elementos são considerados em função de outros elementos e em função da possibilidade de aproveitamento humano.

Em seguida, atribuiu-se pontos para quesitos relativos à posição e ao sítio das áreas selecionadas. ${ }^{90}$ As áreas selecionadas, além de uma nota final elevada, não poderiam ter nenhum critério zerado, mesmo entre aqueles relacionados ao sítio, de menor importância geral. Assim hierarquizadas, as opções de localização da nova capital federal no Planalto Central foram encaminhadas à escolha final a cargo do Congresso Nacional.

Neste trabalho de determinação da localização da nova capital federal, segundo a exposição de Fábio de Macedo Soares Guimarães, além da própria localização, podemos observar com nitidez a lógica cartográfica de apreensão da dimensão geográfica da realidade, quando o autor relaciona características do relevo, vegetação, povoamento e desenvolvimento econômico:

As matas distribuem-se geralmente ao longo dos vales e em capões. Os cerrados e
campos limpos situam-se quase sempre nos topos planos e nas encostas. [...]
As ocorrências importantes de florestas, de conseqüências notáveis no
povoamento e na economia da região, são constituídas justamente pelas exceções:
são os casos em que a presença de matas contraria a regra geral de distribuições
antes enunciada, isto é, os casos em que a vegetação florestal cobre indistintamente
vales, encostas e topos elevados. (GuIMARÃES, 1949, p. 480/482)

Após relacionar a distribuição do povoamento à presença de matas, em decorrência das maiores possibilidades de aproveitamento agrícola, o autor está a um passo de relacionar a densidade demográfica à questão dos transportes. Apenas em decorrência da excelência das condições naturais, o adensamento populacional consegue escapar à necessidade de proximidade aos meios de transporte.

A escolha da localização ideal para um centro político de função unificadora, contudo, não depende apenas da existência de áreas densamente povoadas em zonas de matas de solos férteis, dinamizadas por uma promissora agricultura familiar e pelo fácil acesso a meios de

\footnotetext{
${ }^{90}$ Em termos de posição, foram levados em consideração os seguintes critérios: 1 . situação central em relação às regiões povoadas do país, isto é, em relação ao ecúmeno $(40) ; 2$. situação tal que permita fáceis comunicações com as diversas regiões do país, tendo em vista a função unificadora da capital e mantendo seu estreito contato com a core área (40); e 3. proximidade de uma divisa interestadual (20), totalizando 100 pontos.

Em relação ao sítio, foram levados em consideração os seguintes quesitos: topografia (20); clima (20); abastecimento d'água (15); proximidade de florestas (15); facilidade de produção de energia hidráulica (10), acesso a materiais de construção (5); natureza do subsolo (5); e paisagem atraente (10), totalizando 100 pontos.
} 
transporte. Depende-se, ainda, da densidade de conexões estabelecidas com o centro econômico do país e das possibilidades de desenvolvimento econômico a longo prazo.

O texto de Fábio de Macedo Soares Guimarães, assim, chama a atenção pela objetividade e clareza com as quais capta "fatores geográficos" da realidade por intermédio de tradicionais princípios geográficos, em um destacável exercício descritivo por meio do qual estabelece relações entre os fenômenos em função das relações observadas na realidade, mas também em função dos objetivos propostos.

O encadeamento lógico de "fatores geográficos" em função não apenas do que se observa, mas também do objetivo a que se pretende atingir é um traço importante de materiais publicados sob a entrada GEOGRAFIA ECONÔMICA, objeto a ser explorado no item seguinte da presente dissertação.

\subsection{A PERSPECTIVA TÓPICA DA GEOGRAFIA ECONÔMICA}

Entre o início das publicações da RBG e 1956 publicou-se 32 materiais sob a entrada GEOGRAFIA ECONÔMICA. Embora corresponda ao terceiro tema mais popular publicado na RBG até 1956, apenas $27,8 \%$ dos materiais sob essa entrada concentram-se dentro deste período.

Por influência da classificação proposta pela Biblioteca Central do IBGE, outros 19 materiais publicados até 1956 (24,4\% do total publicado até 1983$)$ foram classificados sob a entrada GEOGRAFIA AGRíCOLA, todos originalmente classificados pelo IBGE sob a entrada AGRICULTURA ou GEOGRAFIA AGRÁRIA. Com efeito, uma análise atenta deste segundo grupo de materiais levou-nos a concluir que a maior parte seria melhor identificada sob a entrada GEOGRAFIA ECONÔMICA. Isso porque na análise conjunta dos materiais sob entrada GEOGRAFIA ECONÔMICA e GEOGRAFIA AGRÍCOLA publicados até 1983, identificamos um expressivo grupo de publicações, 33 no total (incluindo um sobre BIOGEOGRAFIA), versando sobre produtos agrícolas específicos, sob um viés econômico, a partir de um recorte regional. ${ }^{91}$ (vide ANEXO C) Embora essas publicações correspondam a apenas 17\% de todas as publicações sob as duas entradas até 1983, ocorrem de maneira concentrada e correspondem a $47 \%$ das publicações sob essas duas entradas até 1956. Entre 1950 e 1955, foram publicados

\footnotetext{
${ }^{91}$ A identificação de materiais que respeitam estes critérios baseou-se em análise pessoal. Partiu-se da análise dos títulos com vistas a materiais que versassem sobre produtos agrícolas específicos, segundo um recorte regional. Em seguida, consultou-se cada um dos materiais selecionados. O fichamento, por falta de tempo, foi seletivo, sem critério claro de seleção. (vide ANEXO C) Isto posto, a análise é preliminar e pode conter erros em termos de omitir outros materiais que respeitem aos critérios selecionados.
} 
20 destes materiais; sete, apenas em 1952. O último dentro destas especificações foi publicado em 1969.92 A análise conjunta destes materiais parece revelar uma perspectiva de estudos tópicos em Geografia, segundo a proposta de Hartshorne (1978).

Um exemplo de trabalho com enfoque claramente regional, mas que pode ser enquadrado no âmbito da GEOGRAFIA ECONÔMICA, é o artigo Aspectos geográficos da zona cacaueira da Bahia, sob autoria do geógrafo Carlos de Castro Botelho. Este trabalho é exemplar em diversos aspectos, inclusive em termos de estabelecer ligações com outros temas publicados de maneira recorrente na RBG dentro do período considerado.

O artigo de Botelho (1954) é fruto de uma expedição realizada pelo autor e um estagiário, Aluízio Gentil Branco, à zona cacaueira da Bahia, em 1953. (ALMEIDA, 2000; ABRANTES, 2014) Com claro objetivo de tecer um quadro regional segundo uma temática específica, mantém-se firmemente ligado ao propósito de descrever a organização econômica do cacau no sul da Bahia, sem se aprofundar em nenhum elemento isoladamente ou que não tenha direta relação com o gênero agrícola estudado. No início do capítulo 1 , dedicado às condições naturais da cultura cacaueira, o autor deixa claro que não interessam

as descrições e interpretações de cunho puramente geológico, geomorfológico ou climatológico da região. O objetivo é mostrar somente a dependência que se verifica entre a cultura cacaueira e o ambiente sob o qual se estabeleceu. Ao apontarmos as suas relações estarão evidenciados o porque dos limites atingidos e o aparecimento de outras atividades econômicas, presentes na zona cacaueira. (BOTELHO, 1954, p. 161)

O autor aponta o condicionamento climático da cultura cacaueira e como este se relaciona com os aspectos geomorfológicos e pedológicos. A distribuição do cacau, bem com o aparecimento de outras atividades como a pecuária e o extrativismo, são explicadas pela interação e variação destes três fatores naturais.

No Capítulo 2, o autor principia com um breve retrospecto dos antecedentes da economia cacaueira, que apenas se intensifica a partir da última década do século XIX, "com a atração de mão de obra de outras regiões para o sul da Bahia.” (BOTELHO, 1954, p. 167) Em seguida, o autor explora os fatores decisivos para o crescimento e distribuição da população, a saber, a valorização do cacau no mercado externo e a maior exploração das possibilidades pedológicas regionais para este fim, bem como o desenvolvimento das diferentes vias de comunicação. No mesmo capítulo, ainda, Botelho faz uma exposição de cunho sociológico dos "tipos humanos" relacionados às atividades rurais ligadas ao cacau e à organização das classes sociais dentro da cadeia produtiva.

\footnotetext{
92 Os materiais versam sobre a organização produtiva do arroz, babaçu, batata inglesa, borracha, cacau, café, cana-de-açúcar, carnaúba, castanha, erva-mate, fumo, gado, leite, milho, pesca, sal, sisal, suínos, tanino, trigo e uva, em diversas áreas do Brasil.
} 
No capítulo seguinte, Botelho faz uma análise em termos de localização e distribuição das atividades econômicas dentro da área de estudo e compara o mapa regional proposto por ele e o de semelhante temática proposto pelo CNG. Vê-se, a este respeito, que os trabalhos publicados na RBG não representam, necessariamente, o próprio pensamento do $\mathrm{CNG}$, embora possam ser somados ao pensamento deste Conselho.

O autor identifica "dois tipos diversos de lavoura, conforme as relações cacau-mata e cacau-culturas provisórias.” (BOTELHO, 1954, p. 185) Já a atividade pecuária, associada ao cacau apenas enquanto resultado da inversão de capital oriundo desta lavoura, assinala a proximidade com o sertão e os limites de penetração da lavoura cacaueira.

No capítulo final, anterior à conclusão de seu artigo, Botelho faz uma descrição em termos atuais e históricos, das vias de comunicação e assinala a decisiva participação do Instituto de Cacau da Bahia, órgão estadual de valorização da atividade cacaueira, na promoção do rodoviarismo com vistas a esta atividade agrícola. Nesse sentido, aponta o declínio da participação da rede fluvial e dos caminhos de tropas, historicamente associados, devido à expansão da rede ferroviária, e como os trilhos de trem rapidamente entram em decadência, com a interiorização da circulação promovida pelas rodovias. Faz considerações, ainda, quanto à situação e aproveitamento dos portos marítimos.

A disposição dos traçados da ferrovia e das rodovias, estas estendendo-se paralelamente à linha férrea ou unindo as pontas de trilhos, contribuiu para a decadência dos transportes ferroviários. Não houve, de maneira alguma, a preocupação de promover a cooperação entre os meios de transporte. Imperou a concorrência, de efeitos desastrosos para o trem. (BOTELHO, 1954, p. 199)

Nas conclusões de seu artigo, o geógrafo do IBGE aponta para, segundo sua avaliação, a positiva tendência à atividade policultora, com destaque para o desenvolvimento de cafezais e seringais, como alternativa às oscilações do preço do cacau no mercado internacional.

A partir do artigo de Botelho (1954) e da comparação deste material com outros publicados aproximadamente na mesma época, vale destacar um tipo de pesquisa que, frente à concentração de trabalhos similares no período, além situar-se como uma das principais preocupações do CNG na época, parecem fazer referências às proposições do geógrafo Richard Hartshorne (1978).

Uma das pontas do princípio de método proposto por Hartshorne são os estudos que analisam os complexos de fenômenos constituídos de poucos elementos, submetidos à observação em diferentes áreas da superfície terrestre, denominados estudos tópicos. A outra ponta de seu princípio de método prevê, por sua vez, o aumento gradativo do número de fatores em relação, reduzindo-se gradativamente, em consequência, o número de áreas onde o 
complexo de fenômenos pode ser observado, até a realização de estudos regionais onde a complexidade de fenômenos inter-relacionados é máxima e sua observação em outras áreas, mínima. ${ }^{93}$ Ao referir-se especificamente ao critério tópico de lidar com a complexidade de fenômenos em inter-relação na superfície terrestre, afirma o autor:

Encarando a terra de pontos de vista diferentes, é possível que o estudioso queira
concentrar-se em qualquer um dentre vários agrupamentos diversos de integrações
parciais. Acredito que o exame da literatura especializada, excluídos os livros
didáticos, demonstraria que os geógrafos têm obtido mais êxito quando exercem
essa liberdade de combinar os elementos indutivamente, ao invés de seguirem as
divisões convencionais da Geografia Sistemática. (HARTSHORNE, 1978, p. 84)

Um dentre tantos apontamentos realizados pelo geógrafo estadunidense à adequada aplicabilidade de seu princípio de método, a natureza indutiva da pesquisa geográfica impõe ao pesquisador, segundo o método da tentativa e erro, escolher fenômenos que ele julgue, a partir da experiência e da literatura, mais significantes. No contexto das pesquisas realizadas pelo CNG à época do artigo assinado por Botelho (1954), quais fenômenos eram mais significantes de serem estudados?

A análise conjunta destes estudos de caráter tópico deixa clara a determinação extraacadêmica das pesquisas realizadas pelo $\mathrm{CNG}$, cujas temática e enfoque adotados, antes de obedecerem à liberdade de combinar elementos indutivamente e ao julgamento do pesquisador segundo o princípio da tentativa e erro, respondem às necessidades do Estado de tomar conhecimento das realidades empíricas de seu território.

Sendo assim, pode-se depreender a lógica econômica do olhar estatal sobre realidades agrícolas regionais ainda fortemente tributárias de um desenvolvimento histórico em grande parte fortuito. Trata-se, de maneira geral, de compreender economias agrícolas regionais, com vistas à possibilidade de intervenção por parte do Estado e da eventual maior racionalização da produção. São, portanto, trabalhos que podem ser classificados como de GEOGRAFIA AGRÍCOLA, GEOGRAFIA ECONÔMICA ou GEOGRAFIA REGIONAL, sendo difícil propor uma hierarquização. ${ }^{94}$

O ponto de vista de Botelho (1954), portanto, sobre os aspectos geográficos da zona cacaueira da Bahia, que direciona seu olhar sobre determinados grupos de relações entre fatores, parece estar pré-determinado pelas demandas estatais que cabem ao $\mathrm{CNG}$, embora, como assinala Hartshorne e como se pode observar na comparação de outros materiais

\footnotetext{
${ }^{93}$ Cf. Hartshorne (1978), em especial, p. 115-154.

94 Deve-se ressaltar, a este respeito, que a classificação dos materiais publicados na RBG segundo nossa proposta, limitados a uma palavra-chave, chega a seu limite. Não é possível, de fato, identificarmos diversos trabalhos segundo apenas uma entrada. Repetimos, são trabalhos versando sobre realidades fortemente agrícolas, segundo uma perspectiva regional, com a preocupação econômica sempre presente, ainda que em graus distintos.
} 
similares ao trabalho de Botelho, o conceito de "aspecto geográfico" talvez seja vasto demais para que se possa igualar estes trabalhos quanto aos fatores considerados. Nesse sentido, o julgamento do pesquisador, princípio reforçado pelo próprio pensamento hartshorniano, possui liberdade para imprimir às diferentes pesquisas expressivas singularidades.

Trabalhos orientados segundo o princípio metodológico dos "aspectos geográficos" não são difíceis de serem encontrados e nem poderiam, já que refletem uma das principais atribuições do geógrafo junto ao Estado, a de reconhecimento territorial. Tamanha referência à tradição do pensamento geográfico, tal labor também é observável nas teses de doutorado defendidas junto ao DG-USP. Antes de a elas nos determos, na mesma edição em que figura o artigo de Botelho (1954) foi publicado um comentário, assinado por Antônio Teixeira Guerra, sob o título Aspectos geográficos do Território Federal do Acre.

O comentário de Guerra foi fruto de uma expedição entre janeiro e fevereiro de 1954 ao Acre, acompanhado pelo geógrafo Antônio Nascimento e do cinegrafista Tomas Somlo. "A viagem teve por objetivo estabelecer contato com os principais problemas da área em estudo, na qual estão compreendidas as regiões do alto rio Branco e de criação de gado assim como da zona fronteiriça do setentrião brasileiro.” (IBGE, 1954, p. 224) $)^{95}$

Como assinala Guerra em nota de rodapé introdutória, o "trabalho visa a fornecer algumas informações gerais, de natureza geográfica, acompanhadas de amplo documentário fotográfico, tendo em vista o pouco conhecimento que se tem da região.” (GUERRA, 1954, p. 54) De fato, são 23 fotos ao longo de 17 páginas de material. $O$ autor inicia seu relato com observações gerais e introdutórias de ordem geológica e geomorfológica, suficientes para contra-argumentar observações generalizantes de autores como Pierre Gourou quanto ao aproveitamento agrícola das terras amazônicas. Em seguida, realiza observações pedológicas deduzidas a partir das técnicas agrícolas e do aproveitamento agrícola locais e alerta para o homem como agente acelerador da erosão e da intensificação do processo de laterização, já gravemente disseminado em outras regiões. Em termos que extravasam os limites exclusivos da Geografia Física, o geógrafo conclui sua análise com apontamentos de natureza climática:

Êste tipo de clima quente e úmido aliado ao baixo nível cultural dos habitantes da região, condiciona o desenvolvimento do complexo patogênico tropical com grande propagação da febre palustre, parasitas intestinais, etc. (GUERRA, 1954, p. 242)

\footnotetext{
${ }^{95}$ A propósito, na mesma edição do Boletim Geográfico em que foi noticiada a expedição chefiada por Guerra há uma transcrição de um trabalho de Pierre Monbeig, originalmente publicado no jornal O Estado de São Paulo, denominado Aspectos geográficos do Crescimento de São Paulo. Cf. MonBeIG, Pierre. Aspectos geográficos do Crescimento de São Paulo. Boletim Geográfico, v. 12, n. 119, 1954, p. 139-153. (Transcrições.)
} 
Em seguida, Guerra relaciona os aspectos demográficos do habitat às atividades econômicas extrativas. Assinala, então, a desorganização dos assentamentos coloniais e as atividades mais dedicadas à coleta e à caça do que à agricultura e à criação. Mesmo a agricultura de subsistência é escassa. Isto se deve em consequência dos preços compensatórios da exploração de borracha, impondo a necessidade de importação de gêneros alimentícios básicos. Embora existam colônias em todos os municípios do território federal, algumas "nem ao menos possuem as suas terras demarcadas, e consequentemente o loteamento também não foi feito". (GUERRA, 1954, p. 245) Nesse contexto:

A palavra "colono" passou a designar qualquer habitante da zona rural que plante um pouco ou que faça a criação, e "colônia", qualquer agrupamento de homens da zona rural que aliem à atividade da coleta, as da lavoura e pecuária. (GUERRA, 1954, p. 245)

O autor finaliza sua exposição referindo-se ao comércio intra e inter-regional e relaciona com a questão dos transportes. Faz uma crítica à "velha idéia de que na Amazônia, não é preciso pensar na construção de rodovias, tendo em vista o grande número de rios aí existentes." (GUERRA, 1954, p. 248) Contra a ideia, aponta que a variação do nível d'água dos rios impede a passagem de grandes embarcações em numerosas localidades. Para o autor, a construção de rodovias

é portanto um dos problemas que está necessitando um ataque mais rápido, para a sua pronta solução. De grande significação econômica será a construção de rodovias que permitam uma comunicação mais fácil e rápida entre os diversos núcleos populacionais. (GUERRA, 1954, p. 248)

Antônio T. Guerra participaria de outra expedição ao Acre, no ano seguinte, na companhia de Roberto Galvão e do cinegrafista Tibor Jablonsky. O "cunho de reconhecimento da viagem" (GALVÃO, 1955, p. 153) teve por finalidade a realização de uma "Geografia do Brasil”. O artigo resultante desta expedição, assinado por Galvão, fixa-se nos múltiplos aspectos relacionados à economia da borracha e fornece uma rica descrição de detalhes, incluindo-se fotografias, tabelas e belos desenhos ilustrativos feitos pelo próprio autor.

O breve e abrangente cenário descrito por Guerra em seu comentário publicado em 1954 foi, como dissemos, fruto de uma expedição realizada no mesmo ano para a localidade em questão, porém, não é capaz de fornecer ao Planejamento subsídios para a intervenção. Para esta finalidade, mais adequado seria o artigo Alguns aspectos geográficos da cidade de 
Rio Branco e do núcleo colonial seringal empresa, Território do Acre publicado pelo autor em 1951, baseado, aparentemente, apenas em revisão bibliográfica. ${ }^{96}$

Neste artigo, embora restrito ao município de Rio Branco, tem-se uma visão geral do processo de ocupação do território, já que a data de sua publicação é próxima, de todo modo, do período a partir do qual a região passou a ser desbravada. A fundação do município de Rio Branco, sede administrativa do restante do território, está ligada à exploração da borracha por desbravadores nordestinos e a evolução da ocupação, à decadência deste negócio.

Guerra (1951) realiza uma descrição do sítio da cidade, seguida das etapas do processo histórico de sua formação. Em termos de Geografia Urbana descreve o processo histórico de evolução da cidade, centrando-se em termos morfológicos e estruturais. Tanto para o sítio quanto para a análise funcional da cidade, Guerra fornece mapas auxiliares, ainda hoje muito representativos para o entendimento da paisagem local.

A partir da planta funcional da cidade, o autor realiza uma descrição das atividades econômicas praticadas em cada localidade do núcleo urbano, que não chegava, à época, a 10 mil habitantes. Discute-se aspectos do abastecimento e dos meios de comunicação.

Numa segunda parte do artigo, Guerra analisa a questão específica da colonização do Território Federal do Acre cuja economia, até antes de 1942, dedicava-se inteiramente na coleta de produtos florestais, atividade, ainda assim, bastante tardia em relação ao restante da Amazônia. A partir de 1942, houveram esforços concretos de colonização do antigo seringal Empresa, no sentido de desenvolver atividades agrícolas que permitiriam a fixação da população à terra. De fato, o autor descreve um processo em marcha na data da publicação de seu artigo, sem auxílio do distanciamento histórico, portanto.

A autor analisa o processo de demarcação e distribuição de lotes de terra, antevê o processo de urbanização dos lotes e avalia o elevado risco de a lógica da especulação pôr em risco o papel social previsto pelo programa.

A parte final de seu artigo é dedicada à descrição sumária do "Núcleo Colonial Seringal Empresa", resultante da divisão do antigo latifúndio em pequenos lotes, após a crise do negócio da borracha. Conclui o autor que a colonização do seringal Empresa é solução momentânea frente às circunstâncias históricas e seu sucesso a longo prazo depende de maior racionalização em diversos aspectos.

\footnotetext{
${ }^{96}$ Em apenas uma passagem ao longo do texto o autor dá a entender uma eventual visita de campo à área de estudo: "Embora não tivéssemos feito um estudo minucioso da região, não encontramos a formação de crostas de canga como aparecem em vastas porções do território amapaense.” (GUERRA, 1951, p. 567)
} 
Numa comparação em termos gerais, as limitações econômicas tanto dos colonos que pleiteiam os lotes de terra, quanto da assistência técnica e financeira do Estado junto aos pleiteantes, descritas por Guerra, assemelha-se ao quadro descrito por Leo Waibel à Colônia Agrícola Nacional, em Goiás, em 1947. ${ }^{97}$

Waibel, referindo-se à Colônia Agrícola Nacional de Goiás, uma das seis criadas simultaneamente a partir de decreto presidencial em 1941, compara o projeto às homestead farms estadunidenses,

pequenas propriedades agrícolas possuídas por aqueles que trabalham na terra. Que a terra seria dada de graça a gente pobre, é apenas uma modificação do princípio da homestead. Em compensação por estes benefícios, o pioneiro tem que se submeter a regulamentos estritos que lhe cerceiam consideravelmente a liberdade econômica. (WAIBEL, 1947, p. 331)

Distante da última instância administrativa do projeto, a Divisão de Terras e Colonização, sediada no Rio de Janeiro, “o sucesso ou a falência dessas Colônias esta em grande parte nas mãos do administrador e dos seus assistentes.” (WAIBEL, 1947, p. 331-2)

De certa forma, a realidade descrita por Waibel ao projeto de colonização em Goiás é similar ao intento colonizador do Território Federal do Acre, com a diferença de que, em Rio Branco, visava-se valorizar, simultaneamente à agropecuária, a extração de borracha. Imersos numa realidade agrícola de rudimentar nível técnico, vasta quantidade de matas virgens e em face à permissividade do Estado quanto a atividades agrícolas monocultoras predatórias, o pequeno agricultor vê-se impelido a abandonar seu lote de terras tão logo o rendimento de suas terras deixe de compensar ou surja uma nova promessa de enriquecimento rápido. A fixação do homem à terra, bem como o sucesso dos projetos de colonização são, portanto, baixos.

\footnotetext{
${ }^{97}$ Cf. WAIBEL, Leo Heinrich. Uma viagem de reconhecimento ao sul de Goiás. Revista Brasileira de Geografia,
} v. 9, n. 3, 1947, p. 313-43. Trata-se do primeiro material publicado por Waibel no Brasil. 


\subsubsection{A geografia dos "aspectos geográficos"}

Dentro do contexto específico dos trabalhos de natureza tópica voltados à compreensão de economias agrícolas regionais, há outros três trabalhos contemporâneos a Botelho (1954) em cujos títulos explicita-se o princípio metodológico dos "aspectos geográficos" como meio norteador da pesquisa. ${ }^{98}$ Dentre eles, destaca-se o de Mário Lacerda de Melo, denominado Aspectos da geografia do açúcar no Brasil (1954).

Este artigo chama a atenção por ser um dos poucos a tratar de um aspecto econômico em termos não restritos a uma região específica. Nem por isso o trabalho deixa de obedecer a uma lógica regional de análise. O plano de generalidade estabelecido pelo autor permite a comparação das condições de produção observadas no Brasil com a de outros países, mas já no início da redação aponta-se para os fatores internos de diferenciação produtiva, que permite identificar regiões.

Ao realizar sua descrição em um plano mais abrangente, torna-se mais claro o que o autor entende por "geográfico", já que seu nível de abrangência impede a eleição de uma quantidade muito grande de fatores de diferenciação regional.

Por "geográfico" entende-se todos aqueles fatores que, atuando em conjunto, constituem realidades empíricas expressas a partir da paisagem. A atuação destes fatores pode se realizar regionalmente, ou não, como se vê em Melo (1954), a partir do qual as paisagens resultantes da atividade econômica da produção de açúcar são analisadas em escala nacional. Mesmo assim, a articulação de fatores a resultar nas diferentes paisagens sempre se dará em algum lugar, portanto, a possibilidade de identificação de um padrão paisagístico sempre obedecerá a recortes regionais, dentro dos quais é possível se identificar mais semelhanças do que diferenças.

Mário Lacerda de Melo trabalha constantemente com a noção de "mapa". A localização e a distribuição dos elementos que compõem o "mapa açucareiro do país" (MELO, 1954, p. 488) presidem sua análise e suas eventuais prescrições. Embora, evidentemente, não fosse a intenção do autor, a leitura que fazemos de seu artigo, no contexto de autorreflexão da ciência geográfica pós-Geografia Crítica, parece apontar para um indicativo de como se raciocinar geograficamente. A partir da análise da paisagem o autor destaca, segundo uma lógica

\footnotetext{
98 São eles: Melo, Mário Lacerda de. Aspectos da geografia do açúcar no Brasil. Revista Brasileira de Geografia, v. 16, n. 4, 1954, p. 467-492. AlONSO, Delnida Martinez. Aspectos geográficos da cultura fumageira no Estado do Rio Grande do Sul, Brasil. Revista Brasileira de Geografia, v. 20, n. 3, 1958, p. 295-313. DIAS, Catarina V. Aspectos geográficos do comércio da castanha no médio Tocantins. Revista Brasileira de Geografia, v. 21, n. 4,1959 , p. 517-531.
} 
cartográfica cristalina, os elementos peculiares que podem ser encontrados "no tipo de paisagem derivado da forma de aproveitamento humano dos recursos naturais representada pela usina" a que o autor denomina "paisagem usineira":

As amplas construções e as chaminés muito altas são os sinais mais visíveis da presença de atividade fabril. Linhas e desvios ferroviários e trens de cana falam da espécie de matéria-prima usada pela fábrica e da forma de seu transporte. $\mathrm{O}$ armazém de açúcar diz da necessidade de guarda e conservação do produto fabricado e de seu tipo e qualidade. $O$ alto edifício da destilaria indica o aproveitamento de um subproduto - o mel residual - na fabricação de álcool. Os tanques cilíndricos, côr de alumínio, na forma clássica dos depósitos de inflamáveis, revelam a necessidade de estocagem do mesmo álcool assim como vagões-tanque ou camiões-tanque exprimem particularidades de seu transporte. As construções para a administração, as casas dos empregados, as residências operárias, o pátio da feira, a escola, a igreja ou capela são elementos que surgem em função da atividade industrial dominantemente marcada pelo conjunto de construção maiores. Tudo junto forma um aglomerado de função industrial. (MELO, 1954, p. 475)

Da notável descrição da paisagem usineira nítida é a maneira com a qual o autor explicita a dimensão geográfica da realidade. Pode-se apontar as limitações da explicação dessa paisagem, para além dos elementos atinentes ao visível. Mas para Melo não parecia haver dúvida do que é geografia.

O autor assinala para a ausência do caráter rural numa atividade cujo meio de produção depende integralmente da terra. "A própria emprêsa, cultivando a terra, não é apenas industrial, mas agro-industrial. [...] Tipo de habitat sui generis, êsse dos aglomerados das sedes das usinas com atividade dominantemente industrial, mas participando também da vida agrícola.” (MELO, 1954, p. 476)

Ainda para o autor, solo e clima, bem como dimensão territorial, são os elementos que permitem estabelecer uma comparação, em termos concorrenciais, do Brasil com outros países produtores. Ainda que explicite a grande vantagem do Brasil sobre seus concorrentes, sua análise não é profunda o suficiente para explicar de maneira suficiente como países com territórios muito inferiores ao do Brasil conseguiram se inserir nos fluxos de comércio internacional, em um momento em que o incremento da produção nacional se dava quase exclusivamente às custas do fortalecimento do mercado interno.

Já a posição dos núcleos produtores em relação aos principais mercados consumidores, e a ligação destes a questões relativas à geografia da população e dos transportes, tais como distribuição populacional e rede e densidade de transportes, são capazes de explicar, na ótica do autor, a primazia dos núcleos produtores do chamado "Sul Açucareiro" sobre o mais tradicional e antigo "Norte Açucareiro". Aqui, mais uma vez, não há um aprofundamento quanto a mecanismos políticos e econômicos específicos que sabidamente atuaram em benefício dos produtores do Centro-Sul do país, especialmente São Paulo. Apenas nos 
parágrafos finais de seu artigo o autor faz referência, de maneira genérica, a fatores econômicos e financeiros que beneficiaram desigualmente as regiões produtoras de açúcar. Melo faz críticas à política econômica aplicada ao setor açucareiro, mais voltada à correção de preços - estimulando-se, portanto, a produção - do que à prevenção de novos ciclos de retração produtiva.

Não deixa de chamar a atenção, de todo modo, o fato de que, apesar de a atividade econômica analisada por Melo ser a mais tradicional e duradoura praticada no Brasil, remontando mesmo ao início do processo de colonização, o autor não recorre a fatores de ordem histórica para explicar os padrões paisagísticos identificados no Brasil, restringindo-se aos fatores mais relevantes para as especificidades econômicas de seu tempo. Não se trata, vale destacar, de desprezo aos fatores históricos. Ao comparar sumariamente as duas grandes zonas produtoras de açúcar no Brasil, Norte e Sul açucareiros, dentre outros elementos de comparação, o autor destaca a dependência das regiões que compõem o Norte açucareiro em relação à monocultura da cana:

\begin{abstract}
É fato conhecido que a razão de existência da monocultura canavieira em estados do "Norte Açucareiro" não reside somente em fatôres naturais, mas também na própria tradição econômica, nos seculares hábitos de trabalho da população que, em gerações sucessivas, outra cousa não tem feito senão plantar cana e fabricar açúcar. Há, pois, além de outros fundamentos, motivos históricos e sociais de querer o "Norte Açucareiro" persistir em ser açucareiro. Motivos cuja subestimação constituiria grave êrro por parte dos responsáveis pela política econômica do açúcar. (MELO, 1954, p. 472-3)
\end{abstract}

Em suma, trata-se de um estudo tópico voltado à compreensão de um ramo da economia agrícola nacional, com suas especificidades regionais complementares em termos nacionais, mas que criam uma oposição entre os núcleos produtores. Não se trata de um ensaio historiográfico sobre um importante produto da pauta de exportação brasileira, mas da descrição dos caracteres econômicos contemporâneos ao autor. Um estudo, pois, à princípio, a par com o que se espera do $\mathrm{CNG}$ e de seus colaboradores junto à prática do poder. Um saber útil, sem dúvida, que, apesar da pergunta relativa ao real aproveitamento do Estado frente a materiais como este, não parece ser útil apenas ao Estado.

Comparável à descrição da paisagem realizada por Mário Lacerda de Melo (1954), de forma textual, estão os impressionantes croquis de Afonso de Guaíra Heberle (1942) ${ }^{99}$, ilustrador recém-contratado pelo IBGE que, no entanto, morreu de maneira prematura. Embora o domínio paisagístico de Heberle esteja entre os mais notáveis, era comum o uso de fotografias, gravuras e croquis como recurso descritivo entre os geógrafos desta geração.

99 Cf. ABreu, Silvio Fróis. Alguns desenhos de Guaíra Heberle. Revista Brasileira de Geografia, v. 4, n. 4, 1942, p. 843-848, para outras amostras de ilustrações de Heberle e para uma breve contextualização de sua obra. 


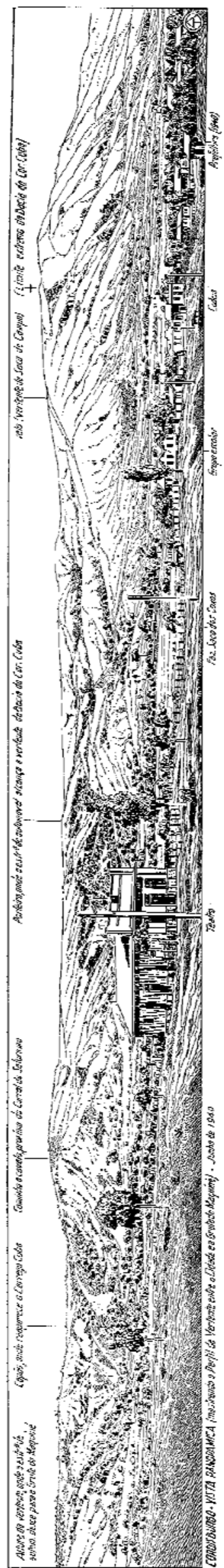

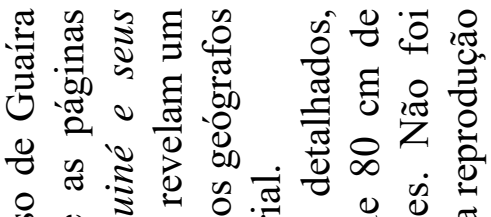

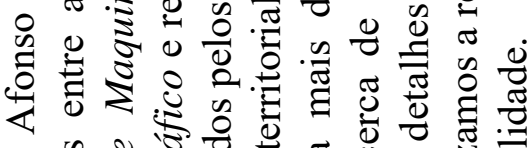

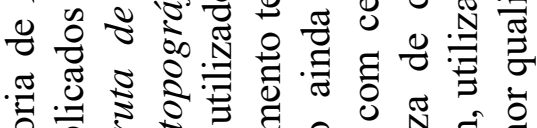

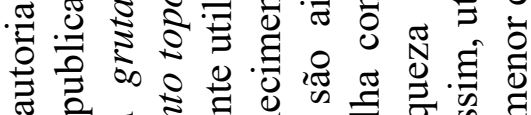

०ᄋ

की

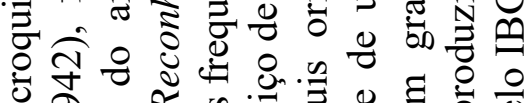

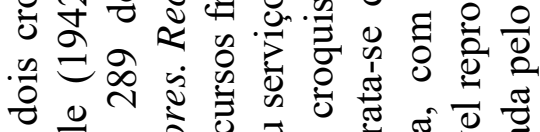

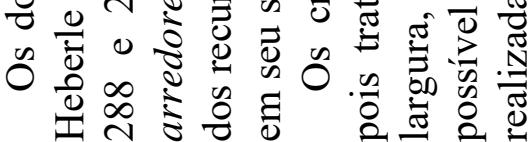

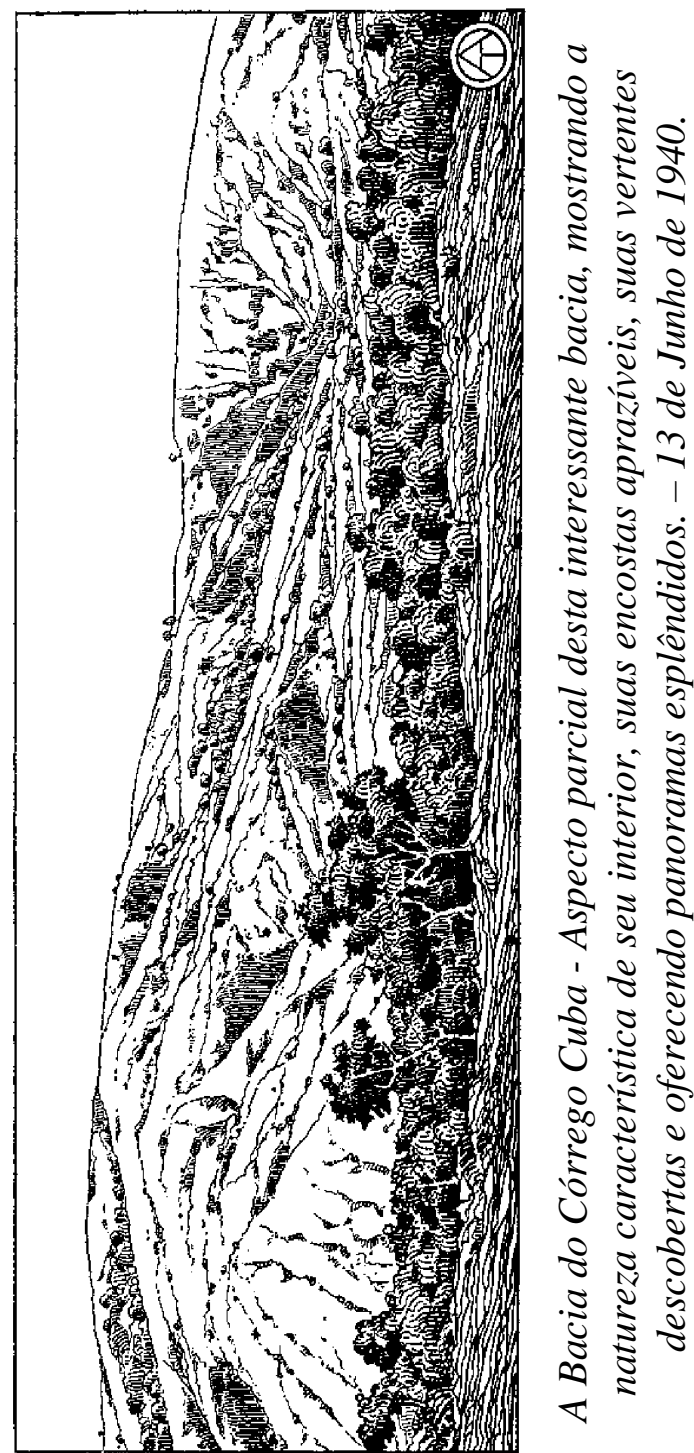




\section{CAPÍTULO 3}

\section{A PARTICIPAÇÃO DO DEPARTAMENTO DE GEOGRAFIA DA USP FRENTE À AÇÃO CENTRALIZADORA DO ESTADO}

Surpreendentemente, salvo engano de nossa parte, não conseguimos encontrar nenhum trabalho acadêmico de grande porte relativo à história do Departamento de Geografia da USP. A pesquisa ficou limitada a artigos de pequenas dimensões e transcrições de entrevistas realizadas em diferentes contextos, além das teses de doutorado publicadas até o ano de 1956. Alguns comentários são necessários a este respeito.

O número pouco considerável de recursos bibliográficos voltados ao presente capítulo, restritos, na prática, às teses de doutorado, constitui uma das grandes limitações da presente pesquisa, talvez a principal delas. Nota-se com nitidez a diferença de tratamento dada à história do CNG e à história do DG-USP na contextualização da instalação da Geografia moderna no Brasil, sem que com isso tenhamos dado menor importância à segunda.

O fato é que, nitidamente, há um certo atraso na reconstituição da história institucional dos principais centros de produção geográfica no Brasil. Importantes publicações a este respeito datam da última década e um volume considerável de artigos tem sido publicados no momento em que se publica esta dissertação. Pode-se citar, dentre outros, o trabalho de Machado (2009) em relação à UFRJ; o de Cardoso (2013), historiadora dedicada à Geografia praticada pela SGRJ no período em grande parte "pré-moderno" da disciplina, entre 1883 e 1945; e diversos artigos a respeito desta primeira fase de implantação da Geografia Moderna no Brasil, tais como Senra (2014), Santos e Castiglione (2014), Aranha (2014), Abrantes (2014), Bomfim $(2014 ; 2015)$, Nogueira (2015) e Salvi (2015) ${ }^{100}$. Com exceção do artigo de Nogueira, a versar no plano acadêmico sobre o conceito de "franja pioneira" em teses de doutorado publicadas no DG-USP, os demais dedicam-se à história do IBGE. A própria natureza recente da recuperação da importância acadêmica do CNG pode ser atestada, por exemplo, na pouca atenção dada por Carlos (2002) à participação do Conselho em termos de produção de pesquisa, ao traçar um rápido retrospecto da formação da ciência geográfica no Brasil. Não se pode, por outro lado, negar a importância de referências basilares como a contribuição seminal de Penha (1993).

\footnotetext{
${ }^{100}$ Com exceção do último, todos os artigos citados foram publicados pela revista Terra Brasilis (Nova Série), que tem dedicado bastante atenção ao referido tema. Já o trabalho de Salvi (2015) foi objeto de apresentação no XI Encontro Nacional da Anpege, em outubro de 2015, e a similaridade com nosso objeto de pesquisa não deixa de nos impressionar.
} 
Não excluímos a possibilidade de termos desconsiderado algum importante trabalho acadêmico dedicado à história do Departamento de Geografia da USP, embora tenhamos dedicado um tempo significativo à busca por referências. A menor insistência a este respeito se deu por motivos práticos e acadêmicos, inter-relacionados. Em termos práticos, o amadurecimento da pesquisa levou-nos à constatação da oportunidade de maior aprofundamento analítico sobre os materiais publicados pela RBG, principalmente a partir da organização dos mesmos em planilha no Excel. Este fato reflete também o amadurecimento intelectual do próprio pesquisador, já que, indubitavelmente, este trabalho deveria ter sido realizado antes mesmo do ingresso no programa de Pós-Graduação. ${ }^{101}$

Em termos acadêmicos, a reconstrução do processo de formação do CNG a partir de fontes fragmentadas, bem como a busca por uma premissa lógica para justificar a seleção de artigos a partir de um universo bastante vasto, tomaram, naturalmente, um tempo bastante amplo, exigindo-nos fazer escolhas.

A reconstrução de uma história do Departamento de Geografia da USP deve, necessariamente, partir de múltiplas fontes de pesquisa, a saber, os materiais já publicados na forma de artigos e transcrições de entrevistas, um amplo acesso a fontes primárias, em especial registros e atas de reuniões no âmbito dos Conselhos do DG e da AGB-SP, além de entrevistas com professores que vivenciaram estes primeiros tempos. Em relação ao material já publicado, acreditamos que a análise das transcrições das entrevistas já efetuadas em diferentes contextos e com diferentes finalidades pode dar um panorama significativo sobre a produção acadêmica e o ambiente político da instituição. A este respeito, é válido ressaltar a emergência em torno da realização de novas entrevistas, principalmente com professores ainda não entrevistados cujas memórias constituem um dos principais patrimônios do Departamento e de onde emerge sua identidade. Quanto à participação da AGB-SP neste cenário, basta afirmar que

As relações entre o Departamento de Geografia e a Associação dos Geógrafos
Brasileiros foram tão estreitas que, sob certos aspectos, em determinados momentos,
suas existências, e atividades, praticamente chegam a confundir-se. No momento, o
que parece mais importante é considerar que determinados aspectos da vida do
Departamento de Geografia não podem ser compreendidos sem que se compreenda
o papel da Associação dos Geógrafos Brasileiros nas atividades dos seus docentes.
(PETRONE, 1982, p. 9)

Frente ao exposto, atestamos certa insuficiência na reconstituição de uma história do DG-USP, mesmo com o objetivo proposto de apenas compor uma contextualização da

${ }^{101}$ Devemos deixar claro, ainda, nossa intenção original de nos restringirmos aos materiais de cunho acadêmico. Enveredamos por materiais de natureza histórica em parte por necessidade de se situar as ideais em debate, em parte por descuido. 
produção acadêmica que emergia junto ao Departamento. O que se pode afirmar, assim, é um forte desequilíbrio na forma de tratamento dos materiais de pesquisa previamente eleitos, já que seis teses defendidas sob os auspícios do Departamento de Geografia da USP estão aquém do tratamento dado aos materiais publicados na RBG e são insuficientes para se alcançar o objetivo inicialmente proposto.

\section{1. "CREA A UNIVERSIDADE DE SÃO PAULO E DÁ OUTRAS PROVIDÊNCIAS"}

A sensível orientação dos primeiros trabalhos publicados junto ao DG-USP para o estado de São Paulo, enquanto que na UDF, embrião da UFRJ, a escala de estudo era eminentemente nacional, aponta para o fato de que, no momento de criação dos dois principais cursos universitários de Geografia do país, a proximidade entre os dois se restringia fundamentalmente à cronológica.

O surgimento de universidades ancoradas em faculdades de filosofia no Brasil, no seio das quais surgem os primeiros cursos universitários de Geografia, está diretamente relacionado ao amplo processo de modernização e burocratização do Estado nacional brasileiro levado à cabo por Getúlio Vargas.

Seja pelo intento de manutenção do controle por parte da metrópole sobre a colônia, durante o período colonial; seja devido ao projeto conservador de manutenção no poder de uma monarquia vinculada aos interesses imperiais da Europa, durante o período imperial, o fato é que tardou ao Período Republicano o surgimento da maior parte das primeiras instituições de ensino superior no Brasil. (FerReIRA, 2009) Ancorada em valores fragmentados e regionalistas, contudo, a República Velha também não foi exitosa na fundação de uma grande universidade nacional, praticante de uma ciência livre e desinteressada, "que deveria ter como fulcro e ponto de apoio uma faculdade de filosofia, ciências e letras". (SCHWARTZMAN, 1988, p. 34) "Na Primeira República a oligarquia agrário-exportadora não tinha maiores preocupações com a análise da realidade brasileira; procurava desenvolver apenas, nas universidades, o ensino dos cursos profissionalizantes, a formação de técnicos em direito, em engenharia, em ciências da saúde.” (ANDRADE, 1994, p. 66) Em meio a um período de ruptura do contexto histórico e de proliferação de alguns estudos clássicos relativos à realidade brasileira, foram os paulistas, em 1934, seguidos pelos cariocas, em 1935, os primeiros a concretizarem o que até então se restringia a projetos. 
A antecedência do surgimento da Universidade de São Paulo - concebida não apenas como a reunião de Faculdades e Escolas de Ensino Superior profissionalizantes até então isoladas, mas também lócus das chamadas Ciências Puras, representadas pela Faculdade de Filosofia, Ciências e Letras que, dentro da estrutura da nova concepção de Universidade, se torna seu coração -, é reflexo do relativo isolamento de São Paulo durante o período colonial ante o centro de tomada de decisões políticas em associação ao seu poderio econômico já em fins do Império e pode ser interpretado de diferentes maneiras.

À margem dos fluxos de riqueza e, por consequência, do centro de tomada de decisões e de controle da colônia, São Paulo posteriormente se beneficiaria extraordinariamente de sua posição e de seus fatores naturais (PRADO JR., 1983) quando a "Providência salvadora" agisse em favor da economia brasileira: a Providência "chegaria até nós sob a forma de um gênero para cuja produção a Natureza nos aparelhara admiravelmente: café.” (PRADO JR., 1981, p. 92) A associação entre uma posição e um sítio urbano favoráveis à mentalidade regionalista de independência e autossuficiência em relação ao Poder Central e a rápida e providencial ascensão de uma nova cultura, o café, deslocam São Paulo da margem ao centro econômico do Brasil em poucas décadas.

As primeiras instituições científicas e técnicas de São Paulo datam do fim do século XIX, e fazem parte do amplo movimento de afirmação do Estado ante o poder imperial, movimento este que se constituiu em um dos fatores mais decisivos na criação da república federativa e descentralizada de 1889. (SCHWARTZMAN, 1988, p. 34)

Com a Constituição de 1889, a intensa descentralização política veio em benefício dos interesses regionais, sendo a elite econômica de São Paulo a que mais tirou vantagem do extremo federalismo. Em termos de instituições de ensino e pesquisa, são diversas as que surgem neste estado nas últimas duas décadas do século XIX, sem paralelo ao observado em outras regiões e com graus distintos de imediatismo quanto à sua finalidade. $\mathrm{O}$ sucesso de muitas delas dependeu em grande parte à liderança cientifica e intelectual de indivíduos que habilmente "impediam que suas instituições se esclerosassem na rotina das repartições públicas ou das escolas profissionais burocratizadas." (SCHWARTZMAN, 1988, p. 34) O surgimento de uma grande universidade, contudo, nos moldes previstos pelo Decreto n. 19.851, de 11 de abril de $1931^{102}$, baseado na existência de uma Faculdade de Filosofia, ainda teria de aguardar a conjuntura específica da Revolução Constitucionalista de 1932.

\footnotetext{
${ }^{102} \mathrm{O}$ referido Decreto, como parte das mudanças na política educacional brasileira, previa em seu artigo $5^{\circ}$ que constituição de uma universidade deveria "congregar em unidade universitária pelo menos três dos seguintes institutos do ensino superior: Faculdade de Direito, Faculdade de Medicina, Escola de Engenharia e Faculdade
} 
A associação dos segmentos mais tradicionais da oligarquia agrária paulista, insatisfeitos por terem sido afastados do jogo pelo poder, aos interesses imediatistas não apenas das elites rurais, mas também das industriais, que viam as medidas de modernização e controle dos sistemas bancário, fiscal e trabalhista do Governo Provisório como maléficos para a manutenção de suas margens de lucros, criou as condições fundamentais para a revolta armada contra o Governo Central, deflagrada em julho de 1932, embora a promulgação de uma nova Constituição tenha garantido o apelo nacional ao movimento. ${ }^{103}$ Perdido repentinamente o apoio de Rio Grande do Sul e Minas Gerais ao movimento às vésperas do combate, São Paulo resistiu sozinha por quase três meses, mas cairia.

A "guerra paulista" teve um lado voltado para o passado e outro para o futuro. A
bandeira da constitucionalização abrigou tanto os que esperavam retroceder às
formas oligárquicas de poder como os que pretendiam estabelecer uma democracia
liberal no país. O movimento trouxe consequências importantes. Embora vitorioso, o
governo percebeu mais claramente a impossibilidade de ignorar a elite paulista. Os
derrotados, por sua vez, compreenderam que teriam de estabelecer algum tipo de
compromisso com o poder central. (FAUSTO, 1999, p. 350)

Debilitado politicamente frente aos demais estados, já que a Revolução de 32 reforçou os temores de que o estado mais rico do país colocaria seus interesses à frente dos interesses nacionais, São Paulo buscou afirmar seu poder no âmbito intelectual, agindo no sentido de criação da USP. A revisão bibliográfica efetuada por Ferreira (2009) em torno do motivo de criação da Universidade, embora indique sutis diferenças de interpretação, aponta para o intento de volta ao poder não pelas armas, mas pelo conhecimento.

Portando, em 1934 se torna concreto o projeto da Universidade de São Paulo, no qual os objetivos são: desenvolver a cultura filosófica, científica, literária e artística; ampliar a investigação científica, isto é, investigações de altos estudos, de cultura livre e desinteressada; formar as classes dirigentes; e fazer com que a universidade prepare o homem como profissional e cidadão. (FERREIRA, 2009, p. 67)

A escolha estratégica por Getúlio Vargas do paulista Armando de Salles Oliveira àquela altura Diretor do jornal O Estado de S. Paulo e cunhado de Mesquita Filho - como interventor do Estado de São Paulo e a direta ligação deste à família Mesquita, um dos principais sobrenomes ligados à idealização da USP desde os anos 1920, revelam que o debate em torno da criação de uma Universidade associado à conjuntura histórica e às

de Educação Sciencias e Letras". Texto do decreto disponível em: <http://www2.camara.leg.br/legin/fed/de cret/1930-1939/decreto-19851-11-abril-1931-505837-publicacaooriginal-1-pe.html>. Acesso em 06 jul. 2016.

${ }^{103}$ É fato que a "elite de São Paulo defendia a constitucionalização do país, a partir dos princípios da democracia liberal." (FAUSTO, 1999, p. 342) Mas é fato também, como já indicado no Capítulo 1, o aspecto puramente formal da democracia praticada durante a República Velha, em relação à qual a tradicional elite paulista se ressentia pelo fim. 
ligações políticas que se desenharam tornaram o momento propício para sua realização. (SCHWARTZMAN, 2006; FERREIRA, 2009)

\subsubsection{Institui-se Faculdade de Filosofia - e a Geografia - no Brasil}

Na base de criação de uma Universidade de comtemplasse uma Faculdade de Filosofia, Ciências e Letras, além do triunfo do sucesso em meio a outras malfadadas experiências ${ }^{104}$, como aquelas empreendidas no Rio de Janeiro, estava o objetivo de desenvolvimento de pesquisa pura e desinteressada, segundo o modelo francês, que fizesse frente à concepção positivista que influenciara a educação brasileira até então. (FERREIRA, 2009, p. 77-79)

A FFCL foi planejada para ser o centro da Universidade de São Paulo e teve sucesso porque para ela foram convidados diversos professores e pesquisadores estrangeiros, assim como brasileiros de alto nível. Se ela tivesse começado somente com docentes brasileiros o fracasso teria sido total. Note-se que à época o Brasil se curvava diante da influência cultural da França. Somando todos esses fatores e a necessidade de formar-se profissionais para áreas do conhecimento em que o atraso brasileiro era incontestável, estruturou-se a Faculdade de Filosofia, cujas finalidades principais eram: preparar trabalhadores intelectuais para o exercício de altas atividades culturais, de ordem desinteressada ou técnica; preparar docentes para o magistério do ensino básico e superior; realizar pesquisas nos domínios da cultura que eram o objeto de uma Faculdade de Filosofia, Ciências e Letras. (PAVAN, 1993, p. 190)

Para tal empreitada, buscou-se contratar missões de professores estrangeiros, franceses, italianos e alemães, para a Faculdade de Filosofia, de modo a desvincular-se os novos cursos do modelo de educação então em prática no Brasil. ${ }^{105}$

A grande decisão tomada naqueles anos foi a de que todos os professores da nova Faculdade de Filosofia deveriam vir do exterior. Graças às incertezas econômicas e políticas na Europa daqueles anos e aos recursos disponíveis por parte do governo de São Paulo, foi possível enviar uma missão de recrutamento para a Europa e atrair jovens professores da Itália, da Alemanha e da França. (SCHWARTZMAN, 2006, p. 165) ${ }^{106}$

\footnotetext{
104 “Outra coisa surpreendente, ao meu ver, é que, a despeito de o Rio de Janeiro ter sido a Capital Federal, foi em São Paulo que se deu o passo inicial para se ter no Brasil uma verdadeira universidade. Como é sabido, isso se deveu a Júlio de Mesquita Filho, ao jornal O Estado de S. Paulo e a Armando Salles de Oliveira. Assim, apesar desse atraso face ao sucedido em outros países latino-americanos tivemos a oportunidade de nos destacar e de sobressair com relação aos países vizinhos. [...]” (PAVAN, 1993, p. 189-190)

105 “O professor da Faculdade de Direito Teodoro Ramos foi enviado à Europa, em 1933, para trazer docentes para o Brasil no intuito da criação de uma universidade articulada pelo governo do Estado, do interventor Armando Salles de Oliveira e patrocinada pela família Mesquita, dona do jornal O Estado de São Paulo." (AB'SÁBER, 2005, p. 13, nota 2.)

106 Por pressão das colônias alemã e, especialmente, italiana, o governo do estado de São Paulo se viu obrigado a contratar professores não apenas da França, mas também da Itália e Alemanha. Frente ao avanço dos ideias nãoliberais destes dois países, que se opunham aos ideais fundadores da USP, o impasse foi habilmente resolvido direcionando-se os profissionais italianos e alemães para carreiras eminentemente "aplicadas" e reservando-se as carreiras ligadas ao "espírito" aos franceses. (FERREIRA, 2009, p. 86-87)
} 
Segundo o Decreto Estadual de 1934 de criação da Universidade de São Paulo ${ }^{107}$, assinado na significativa data de comemoração da fundação da cidade de São Paulo, 25 de janeiro, a Faculdade de Filosofia, Ciências e Letras, uma das dez faculdades, escolas e instituições que originalmente fundaram a Universidade, seria dividida em três seções autônomas, que lhe davam nome: Filosofia, Ciências e Letras. A seção de Ciências, em seis subseções: Ciências Matemáticas; Ciências Físicas; Ciências Químicas; Ciências Naturais; História e Geografia, e Ciências Sociais e Políticas. A subseção de Geografia e História, única em não contar com o nome de "ciência", era dividida em quatro cadeiras e possuía cinco disciplinas: Geografia Geral e Antropogeografia; História da Civilização; História da América; e História da Civilização Brasileira. O Art. 10 do Capítulo II do Decreto n. ${ }^{0} 6.283$ dispõe sobre a forma que seriam desenvolvidos os cursos:

Art. 10 - O curso para licença cultural será e seriado e de três anos, em cada uma das secções e sub-secções que compõem a Faculdade de Filosofia, Ciências e Letras, abrangendo todas as matérias da respectiva secção ou sub-secção e outras afins ou fundamentais [...] (BRASIL, 1934)

O curso de Geografia e História apresentaria a seguinte estrutura curricular:

$1^{\circ}$ ano - Geografia geral, Geografia econômica, História da Civilização (antiga e medieval);

$2^{\mathrm{o}}$ ano - Antropogeografia, Geografia econômica do Brasil história da Civilização (moderna e contemporânea), História da América (inclusive pré-histórica);

$3^{\circ}$ ano - Antropogeografia (especialmente do Brasil), História da América, História da Civilização Brasileira. (BRASIL, 1934)

Segundo Ferreira (2009, p. 75) o "aluno concluinte de qualquer um dos cursos oferecidos pelas secções ou subsecções teria a licença cultural e seria considerado licenciado; havendo apenas três classificações: licenciado em filosofia; licenciado em ciências; e licenciado em letras."

Art. 11 - Terminado o curso, em qualquer das secções ou das sub-secções, ao candidato será dada licença cultural respectiva, considerando-se licenciado em filosofia, em ciências ou letras.

Parágrafo único - Fica facultada ao candidato inscrição em qualquer das secções, ou sub-secções, para fazer o curso seriado completo, de três anos, ou o curso de uma ou mais disciplinas de escolha livre, segundo o critério de especialização. (BRASIL, 1934)

Para a obtenção do grau de Doutor, dispôs o Art. 12:

${ }^{107}$ BRASIL. Decreto n. ${ }^{\circ}$ 6.283, de 25 de jan. 1934. Crea a Universidade de São Paulo e dá outras providências. Disponível em: <http://www.leginf.usp.br/?historica=decreto-n-o-6-283-de-25-de-janeiro-de-1934>. Último acesso em: 08 de julho de 2016. Para uma descrição comentada do Decreto, cf. também: FERREIRA, 2009, p. 68-76. 
Art. 12 - Para o doutoramento em cada uma das secções ou sub-secções, o licenciado é obrigado, a um curso e estágio de dois anos, em seminários ou laboratórios, findos os quais lhe será conferido o grau de doutor se aprovado na defesa de trabalho original, de pesquisa ou de alta cultura. (BRASIL, 1934)

Quanto à Geografia, especificamente:

As origens do atual Departamento de Geografia da Faculdade de Filosofia, Letras e Ciências Humanas da U.S.P. estão estreitamente vinculadas ao funcionamento da antiga sub-secção de Geografia e História da Faculdade de Filosofia, Ciências e Letras. No ano de 1934 quando, com a criação da Universidade de São Paulo, foi instalada a Faculdade de Filosofia, C:ências e Letras, começou a funcionar, também, a sub-secção de Geografia e História. (PETRONE, 1982, p. 7) ${ }^{108}$

Segundo Seabra (2004, p. 26-27), a cátedra de Geografia do curso de Geografia e História foi inaugurada por Pierre Deffontaines em maio de 1934, geógrafo marginal na França em decorrência de suas filiações ideológicas - um católico de esquerda num universo republicano laico. Retorna à França em dezembro do mesmo ano, mas com intenções explícitas de retomada da cadeira em 1936. Sua experiência já era grande e suas competências - engajado, organizador e com prática nos meios de publicação -, adequadas para a fundação de uma nova cadeira. Seu retorno a São Paulo foi, no entanto, obstado por Pierre Monbeig, que chegou em São Paulo em fevereiro de 1935.

Em seu retorno ao Brasil em 1936, assumiu semelhante função de fundador de cátedra junto à Universidade do Distrito Federal, onde permaneceu até 1938. Sua intenção explícita era retornar a São Paulo e dar continuidade aos trabalhos iniciados. Contudo, além de problemas de relacionamento entre professores membros da missão francesa no Brasil, ele e Monbeig possuíam a mesma especialidade, ao passo que se planejava a abertura de uma cadeira de Geografia Física em São Paulo.

Sua influência cultural francesa em São Paulo foi, contudo, grande. Foi ele o fundador, ainda em 1934, da Associação dos Geógrafos Brasileiros. Além disso, sua intenção era o desenvolvimento de uma proposta preliminar de divisão regional do estado de São Paulo, iniciada já em 1934, semelhante ao que se fizera na França, a partir da qual se sucederia inúmeras monografias de cada região. Deffontaines de fato legou uma proposta de divisão regional, como veremos, cuja influência sobre a primeira geração de geógrafos paulistas merece ser melhor investigada.

A cátedra única, de Geografia, foi desdobrada em duas em 1939: Geografia Humana e Geografia Física:

\footnotetext{
${ }^{108} \mathrm{O}$ artigo de Pasquale Petrone relativo à história DG-USP, primeiro artigo do primeiro volume da Revista do Departamento de Geografia da USP é nossa melhor referência. Cf. PETRONE, Pasquale. Anotações sobre o Departamento de Geografia. Revista do Dep. de Geografia, v. 1, 1982, p. 7-19.
} 
A primeira ficou sob a responsabilidade do Prof. Pierre Monbeig até o ano de 1946, ocasião em que o referido professor foi substituído pelo Prof. Ary França. A segunda ficou sob a responsabilidade do Prof. João Dias da Silveira. No ano de 1942, às duas existentes somou-se a cátedra de Geografia do Brasil, sendo regente o Prof. Aroldo Edgar de Azevedo. (Petrone, 1982, p. 7)

Ao longo da segunda metade dos anos 1940 ocorreram os três primeiros concursos públicos para provimento de cátedra, que consolidaram os professores brasileiros em suas posições e que, de certa forma, inauguraram o desenvolvimento da Geografia da USP por profissionais brasileiros formados a partir da contribuição dos geógrafos franceses.

Em 1946, foi criado o Departamento de Geografia, destinado a coordenar os trabalhos, em termos didáticos e administrativos, das cadeiras que se dedicavam ao ensino e às pesquisas de Geografia. O Departamento surgia, portanto, como um instrumento de coordenação das atividades das cátedras. Assim, o DG gradativamente passou a se organizar em torno dos professores catedráticos e, posteriormente, seus assistentes. Pode-se destacar esta primeira fase da Geografia da USP, portanto, como a de implantação de suas bases de funcionamento.

\subsection{O CURSO DE GEOGRAFIA NO RIO DE JANEIRO ${ }^{109}$}

O primeiro curso de Geografia do Rio de Janeiro surgiu junto à Escola de Economia e Direito da recém-criada Universidade do Distrito Federal (UDF), em 1935. O objetivo desta Escola era a investigação do Brasil, "tão pouco conhecido pelos brasileiros naquele momento. Por sua vez, seus objetivos estavam voltados para a construção da identidade nacional", mediante a formação de professores e a modernização científica das áreas de conhecimento. (MACHADO, 2009, p. 65-66)

Segundo Machado (2009, p. 36-37), embora a modernização das instituições tenha sido singular na década de 1930, vale lembrar que nas primeiras décadas do século XX registrouse "um aumento considerável dos órgãos públicos, resultado, principalmente, da reorientação da política internacional que começava a ser realizada por meio dos relacionamentos entre os governos federais." Assim, a cidade do Rio de Janeiro "aglutinou as modernas instituições federais e concentrou o poder decisório em nível nacional.” Sua condição de capital federal tornou seus estilos e valores um modelo para a nação, propostos e reconhecidos como civilizadores.

\footnotetext{
109 Para uma completa apreciação do desenvolvimento histórico da ciência geográfica praticada no Rio de Janeiro, cf. MACHADO, Mônica Sampaio. A construção da Geografia universitária no Rio de Janeiro. Rio de Janeiro: Apicuri, 2009.
} 
Possibilitou igualmente uma forte influência do Governo federal e de todo um aparato burocrático, que imprimiram à cidade um contexto urbano cultural específico, principalmente se comparado ao contexto urbano paulistano, marcado à época não apenas pela expressão do mercado como por uma burocracia estatal, cujos interesses difundidos atendiam às elites políticas regionais. (MACHADO, 2009, p. 37)

Além de terem incorporado à vida local a agenda nacional, as instituições federais concentravam maior capital técnico e social, "portanto, maiores recursos financeiros, os quais acabaram estabelecendo relações de estreita dependência com outras instituições menos privilegiadas do pondo de vista do apoio governamental." (MACHADO, 2009, p. 39) A implantação do curso universitário de Geografia na UDF quase simultaneamente à criação do IBGE é exemplar nesse sentido.

Da Primeira República à década de 1920, com a fundação da Associação Brasileira de Educação (ABE), aprofundou-se entre os círculos politizados o debate, ainda sem o acirramento quanto a orientações ideológicas, sobre a importância da instalação de um sistema organizado de educação pública. "Logo, porém, em 1931, as diferenças de opinião começam a se cristalizar no seio do Estado e da ABE, e as disputas pelo controle da educação se efetivam na polarização entre o movimento da Escola Nova e a Igreja Católica, ou seja, entre os reformadores liberais e os pensadores católicos.” (MACHADO, 2009, p. 56) Gradativamente triunfaram os interesses da Igreja Católica, principalmente a partir do Estado Novo. A UDF, apesar disso, foi criada dentro de um esforço travado por Anísio Teixeira à frente de seu amplo projeto educacional, de cunho liberal, em um momento em que o embate político radicalizava-se a ponto de abarcar, mesmo, questões pessoais.

A despeito, porém, do acento liberal subjacente à concepção da UDF, que a distanciava do modelo educacional adotado prioritariamente pelo Governo Federal, sua existência reproduzia em grande medida a agenda nacional. Ao objetivar eliminar distorções na atividade cultural brasileira, especialmente quanto ao isolamento acadêmico e intelectual em relação a outras nações, "a UDF buscava se estabelecer como um núcleo de formação do quadro intelectual do país, até aquele momento formado ao sabor do abandono e de precário autodidatismo." (MACHADO, 2009, p. 59) Nesse sentido, a modernização do sistema educacional

deveria ser conduzida por ações políticas e científicas de uma elite dirigente informada, e o ingrediente principal dessas novas elites, habilitadas a assumir a tarefa de construção política de uma nação moderna, deveria emergir das novas ciências sociais, da qual a Geografia era parte constituinte. (MACHADO, 2009, p. 60)

A ascensão do intervencionismo estatal e a criação da Universidade do Brasil, em 5 de julho de 1937, levaria, mesmo, a UDF à extinção em 20 de janeiro de 1939, mas, nem por 
isso, a inovação e a excelência acadêmica deixaria de pautar a criação dos novos cursos e a contratação de professores.

Em sua curta existência, a UDF contou com a colaboração de intelectuais como Fernando Antônio Raja Gabaglia e Carlos Delgado de Carvalho, em torno de Pierre Deffontaines. Além de eruditos, partilhavam o projeto de modernização da ciência geográfica no Brasil e de "invenção da tradição nacional", intento partilhado por outros intelectuais sediados no Rio de Janeiro e influenciados pelo programa de Getúlio Vargas. Esses

intelectuais vão privilegiar em suas obras uma abordagem sustentada na escala do Brasil-nação, na escala territorial nacional. O Brasil é tratado a partir de uma nova perspectiva regional, delimitada pela fisionomia da superfície terrestre, fisionomia que também é fruto da ação do homem sobre a paisagem, a qual transcendia os limites territoriais pelos poderes regionais oligárquicos e possibilitava a realização do projeto tão desejado pelo Governo federal: a construção da identidade nacional. (MACHADO, 2009, p. 90)

Essa proposta, ancorada na descrição do território nacional, seria o fio condutor do curso de Geografia e História da Faculdade Nacional de Filosofia (FNF). Vinculada à Universidade do Brasil, a FNF surgiu em 4 de abril de 1939, sob direta tutela do Governo Federal, mas herdou os princípios de excelência acadêmica e prática de ciência desinteressada que fundaram a UDF. Ora, a defesa de uma Geografia pátria, de uma Geografia ancorada numa concepção de Brasil-nação, seria o argumento principal em torno da incorporação do CNG ao INE, a formar o IBGE, imediatamente aproximando, pois, os dois centros de pesquisa geográfica.

Em contrapartida estava o projeto paulista, sustentado no federalismo oligárquico e, portanto, no seu fortalecimento regional, estatual, e na ideia de estabelecimento de um diálogo permanente com o mundo, um projeto que parece ter sido levado à frente pela USP, que busca defender internacionalmente sua marca de excelência. (MACHADO, 2009, p. 106-107)

Assim, a condição histórica de capitalidade do Rio de Janeiro, ao mesmo tempo facilitou o trabalho dos geógrafos, em função do aporte financeiro decorrente da excessiva proximidade com o poder estatal, dificultou qualquer desvinculação com o Estado e a construção intelectual de visões politicamente independentes do governo federal.

A estreita ligação da Geografia universitária carioca com as agências estatais fica evidente quando se observa o magno interesse pelo ensino da Geografia desvinculado do ensino da História.

Apesar de Geografia e História constituírem uma só seção na UDF, o Curso de Geografia é implantado e desenvolvido separadamente do Curso de História, dado singular, se comparado à historiografia da Geografia na Universidade de São Paulo e na Universidade do Brasil. (MACHADO, 2009, p. 66) 
Com a criação da FNF, a Geografia perdeu sua independência departamental ante a História, assemelhando-se ao curso praticado na USP, porém, mesmo assim, a separação dos ofícios era clara. Os departamentos eram inclusive independentes, com catedráticos especializados representando interesses distintos. Nomes como Christóvam Leite de Castro, Jorge Zarur e Fábio de Macedo Soares, formados em Geografia pela UDF e ocupantes de cargos importantes no IBGE, bem como Francis Ruellan, Delgado de Carvalho e Victor Leuzinger, influentes catedráticos de Geografia da FNF, reuniam-se em reuniões da AGB, verdadeiras vitrines do pensamento geográfico nacional, nas quais se organizava excursões em grupo e autênticos trabalhos científicos de reconhecimento territorial na forma de relatórios de campo. Este universo institucional, que articulava Universidade, IBGE e uma entidade de classe, financiado por demandas estatais e carente de profissionais especializados, reforçava a impressão da inconveniência da ligação disciplinar da Geografia com a História.

Até os anos 1950, o curso de Geografia da FNF atuaria exclusivamente formando professores para a rede básica de ensino e profissionais especializados para atuar junto ao IBGE. Em troca, o IBGE fornecia recursos materiais, técnicos, profissionais e financeiros que complementaria a formação acadêmica. (MACHADO, 2009)

A separação dos cursos de Geografia e História nas Faculdades de Filosofia, evidenciam as articulações e "redes de relações dos novos profissionais de Geografia" formados por essas faculdades. (MACHADO, 2009, p. 144) Já no IX Congresso Brasileiro Geografia, em 1940, o assunto veio à tona, sendo retomado no congresso seguinte, em 1944. Neste, o assunto é colocado já em termos definitivos no discurso de abertura do Ministro Gustavo Capanema, que refletia uma solicitação expressa por parte do Diretório Central do CNG e que tinha apoio da Universidade do Brasil.

Na resolução n. 156, de 18 de abril de 1944, do Diretório Central do CNG, defende-se "a necessidade de uniformizar os currículos dos cursos de Geografia das faculdades de Filosofia do país. Assim, preparava-se uma reformulação do ensino superior de Geografia em todo o Brasil, a partir do Rio de Janeiro e do seu importante núcleo de poder, o CNG, o que fez com que vozes de insatisfação começassem a ecoar no núcleo paulista, primeiramente através de Pierre Monbeig". (MACHADO, 2009, p. 149) ${ }^{110}$

A separação se consolidou apenas em 1955 e, com ela, se define efetivamente o campo profissional da comunidade geográfica brasileira, constituída de geógrafos de formação.

\footnotetext{
${ }^{110}$ Pierre Monbeig publicou um comentário no Boletim Geográfico dedicado à crítica da separação do curso de História e Geografia. Cf. MonBeIG, Pierre. Estudos Geográficos. Boletim Geográfico, v. 1, n. 11, 1944, p. 7-11.
} 
Em São Paulo, passados dez anos da criação do Departamento de Geografia, o curso de Geografia foi separado do de História em 1956, por força da Lei Federal n. 2.549, de 08.09.1955, complementada pelo Decreto Estadual n. 25.701, de 04.04.1956 ${ }^{111}$.

A criação de um curso voltado especificamente para a formação de bacharéis e licenciados cm Geografia permitiu que o Departamento adquirisse formalmente um contorno mais nítido, na medida em que passava a identificar-se com um curso específico, fato que não se verificava anteriormente. (PETRONE, 1982, p. 9-10)

Também em São Paulo, havia a sensação de que os cursos deveriam separar-se. Um dos principais fatores a reforçar o caráter de unidade departamental da Geografia, segundo Pasquale Petrone (1982), foi o fato de o curso ter ocupado sucessivamente instalações não coincidentes com o restante da Faculdade, de certa forma isolando-o e fomentando necessidades específicas e condições para a futura separação.

\subsection{A IMPORTÂNCIA DA AGB-SP}

Como já exposto, não se pode desconsiderar a atuação da Associação dos Geógrafos Brasileiros no conjunto das atividades do Departamento de Geografia da USP. ${ }^{12}$ Manoel Seabra destaca a relação de complementaridade existente entre a Cátedra de Geografia da USP e a recém-criada entidade de classe, ambas fundadas por Pierre Deffontaines.

A criação da AGB-SP está diretamente relacionada à inauguração da cadeira de Geografia na subseção de Geografia e História da FFCL da USP pelo geógrafo francês que, em solo brasileiro, reproduziu a organização profissional existente na França. ${ }^{113}$ Neste sentido, a existência e vitalidade da AGB estavam intimamente relacionadas às ações, inicialmente de Deffontaines e, posteriormente, de Pierre Monbeig e Caio Prado Jr., de promoção do saber geográfico. (SEABRA, 2004) Pasquale Petrone (1982), por sua vez, aponta para o fato de que parte considerável da produção intelectual do DG-USP pode ser encontrada

111 O referido decreto estadual contempla a estrutura curricular dos dois cursos. Nele, pode-se observar uma disciplina de Geografia no currículo do curso de História e também o contrário, característica que permanece até hoje. Cf. Paula, Eurípedes Simões de. Desdobramento do curso de Geografia e História na Faculdade de Filosofia, Ciências e Letras da Universidade de São Paulo. Revista de História, v. 12, n. 25, 1956, p. $285-286$.

112 A bibliografia historiográfica relativa à AGB é bem mais volumosa do que aquela relativa ao DG-USP. A pouca atenção dada à história da AGB e sua estreita relação com o DG-USP, devido às próprias limitações da pesquisa, aponta para outra grande limitação do presente texto. A este respeito, cf., especialmente, ANTUNES, Charlles da França. A Associação dos Geógrafos Brasileiros (AGB) - origens, idéias e transformações: notas de uma história. Niterói, 2008, 310 p. Tese (Doutorado) - Departamento de Geografia, Universidade Federal Fluminense.

113 "É portanto de toda oportunidade a ASSOCIAÇÃo DOS GEÓGRAFOS BRASILEIROS, fundada em redor da cadeira de geografia da Universidade de S. Paulo, e que reúne estudiosos e amadores da geografia animados da mesma paixão de descobertas e compreensão do seu paiz.” (DEFFONTAINES, 1935. In: CUSTÓDIO (Org.), 2012, p. 11) 
nas publicações vinculadas à AGB-SP: Revista Geografia ${ }^{114}$, Boletim da AGB ${ }^{115}$, Boletim Paulista de Geografia, Anais da AGB e, ainda, nos "Avulsos” da mesma Associação. De fato, um simples exame do corpo editorial dos exemplares do Boletim Paulista até os anos 1950 é suficiente para a constatação da ligação dos geógrafos ligados ao Departamento à Associação.

Para a fundação da AGB, em 17 de setembro de 1934, Deffontaines buscou reunir notáveis da intelectualidade local, não-geógrafos mas francófonos, "visando reunir-se para palestras e debates e organizar-se para a realização de estudos e pesquisas interessando à Geografia”. (SEABRA, 2004, p. 14) Dentre eles, Caio Prado Jr. que, além de um dos fundador da Associação e aluno da primeira turma do curso recém-criado, foi o primeiro secretário da AGB e, na prática, o editor do primeiro ano da revista Geografia. Os primeiros associados da AGB e mesmo a primeira turma do curso de Geografia e História poderiam, em sua maioria, serem considerados "notáveis locais", na medida em que eram todos francófonos e já experientes profissionais em suas áreas de formação e atuação.

$\mathrm{Na}$ tentativa de reconstituir a visão do próprio Caio Prado Jr. e as motivações que o levaram a aproximar-se da Geografia, Seabra utiliza a documentação original da AGB, sem perder de vista que os documentos talvez reflitam apenas - ou pelo menos - a visão da maioria dos associados. Assim, a partir das correspondências redigidas por Caio Prado Jr., a AGB, do ponto de vista acadêmico, deveria ser:

Um centro de estudos geográficos eficiente - um centro ativo de estudos metódicos e sistemáticos [...] um laboratório de estudos e de trabalhos científicos [...] (que) está destinado a agregar todos os estudiosos da matéria [...], (pois) empenhada na obra de renovação da Geografia brasileira, [...] (sendo que) a articulação e coordenação de todo o trabalho geográfico que se realiza no nosso paiz, faz parte do programa da

\footnotetext{
${ }^{114}$ Foram publicados sete exemplares, quatro em 1935 e três em 1936. As publicações relativas ao ano de 1935 são fruto indiscutível do esforço pessoal de Caio Prado Jr., sem o qual a revista não teria sido publicada tão cedo. (SEABRA, 2004, p. 57)

"Tornando-se desejável a conservação do fruto deste trabalho comum [registro das reuniões e excursões realizadas pelos participantes da AGB], foi decidida a publicação duma revista. Tal iniciativa permitirá também interessar um grande publico pelo conhecimento dos problemas geográficos locaes e mesmo geraes, entreter uma opinião favorável a estes estudos.” (DEFFONTAINES, 1935. In: CUSTÓDIO (Org.), 2012, p. 12)

${ }^{115}$ O "Boletim da AGB n. 1", publicado no v. 3 da RBG de 1941, faz breve consideração à revista Geografia, sem esclarecer o real motivo do abandono da antiga publicação. "A ideia de um Boletim da Associação já apareceu por ocasião da aprovação dos primeiros estatutos, no final de 1934.” Aparece como uma seção da revista Geografia, a partir do n. 2. Com o n. 1 do Boletim projetava-se uma relação duradoura com o CNG. À época, a AGB já estava associada ao CNG há mais de um ano. "Esperava-se que o Boletim fosse o traço de união entre os vários núcleos da AGB que viessem a surgir e isso se faria sob os altos auspícios" do CNG. Porém, já o Boletim n. 2 foi publicado de forma autônoma pela AGB, que ainda cita o apoio do CNG. No Boletim n. 3, já não há referências ao apoio do CNG, mas da Reitoria da USP. O Boletim n. 3 cresce em número de páginas e se aproxima muito da antiga revista Geografia. Foram publicados 5 Boletins no total, até 1944, e sua publicação também se interrompe de maneira abrupta. Uma nova publicação surgiu apenas em 1949, com o Boletim Paulista de Geografia. (SEABRA, 2004, p. 60/61) Diversas teses de doutorado defendidas junto ao DGUSP foram publicadas na forma de Boletim da AGB, constituindo-se em verdadeiros livros.
} 
Associação [...] (para) dar aos estudos geográficos no Brasil, e particularmente em São Paulo, o caráter orgânico que lhes falta. (SEABRA, 2004, p. 31-32) ) $^{116}$

Nota-se as elevadas ambições da Associação, que buscava não restringir sua atuação à reunião de geógrafos e profissionais de áreas afins, mas atuar, com efeito, no âmbito da pesquisa original, segundo os preceitos indutivistas da época. Nesse sentido, uma publicação seria da maior importância, para atender a um ponto fundamental: "divulgar os conhecimentos geográficos e interessar o público por uma ciência da maior importância cultural e prática." (SEABRA, 2004, p. 32, grifo nosso.) A revista Geografia contribuiria para a análise de diversas questões relativas ao território e à nação, particularmente os de ordem econômico e social, pois os problemas "precisam ser abordados antes de mais nada por seu aspecto geográfico, que não é outra coisa senão o estudo de sua distribuição no espaço.” (SEABRA, 2004, p. 32-33)

Aparentemente, a dimensão acadêmica e institucional almejada pela AGB, não diferia, grosso modo, daquela pretendida pelo CNG. Mas, conforme aponta Seabra (2004), pode-se polarizar o debate dentro da AGB relativo ao seu papel, assinalando-se também a influente opinião de outro fundador da Associação, o prestigiado geólogo e professor da Escola Politécnica da USP Luiz Flores de Moraes Rego, para o qual a Geografia deveria prestar-se à expansão do capital paulista.

Caio Prado Jr. resume em ata de 04.02.1935 a opinião expressa por Moraes Rego, opinião também expressa n'O Estado de São Paulo de 28.03.1935:

pediu a palavra estendendo-se em considerações sobre a importância e o papel
prático da Associação na expansão econômica do Estado de São Paulo e na
penetração nos estados vizinhos seus tributários naturais [sic]: Paraná, Mato Grosso,
Goiáz e mesmo Triângulo Mineiro. Tal penetração depende antes de tudo de um
conhecimento preciso do terreno geográfico em que ela se vai operar; daí o papel
importante que a Associação poderá representar nela. Propõe, portanto, que os
trabalhos da Associação se orientem neste sentido, sendo organizados programas
mais amplos que abranjam o estudo destas regiões tributárias acima referidas.
(SEABRA, 2004, p. 33, grifos e sic de Seabra.)

Moraes Rego tinha experiência, em geologia, “de realização de estudos de caráter científico voltados ou feitos com objetivos práticos mais ou menos imediatos e relacionados com seu aproveitamento econômico." Apesar de não se poder afirmar que Moraes Rego esperasse apenas esse direcionamento à Geografia, "as suas afirmações são por demais evidentes e explícitas e permitem que se atribua a ele uma posição 'imperialista' em favor do Estado de São Paulo." Na $8^{\text {a }}$ reunião da AGB, onde Caio Prado registra sua opinião, não há registros de objeção à sua opinião, mas Seabra também não encontra, nos registros que

\footnotetext{
${ }^{116}$ Seabra se refere a passagens de sete documentos diferentes, aqui não identificados. Para a consulta aos códigos dados a cada documento, cf. SEABRA, 2004, p. 31.
} 
analisa, "registros de organização de estudos e pesquisas especificamente neste sentido". (SEABRA, 2004, p. 34)

Vale apontar, frente ao exposto por Manoel Seabra, a ainda reduzida envergadura econômica e institucional da AGB-SP, naquele período, bem como a falta de uma proximidade maior com os possíveis financiadores de pesquisa, dentre eles a burguesia paulista e o Governo Estadual. Mas é fundamental assinalar, também, a maneira como a Associação em seus primeiros anos reproduziu, em primeiro lugar, o papel que a historiografia geográfica atribui à Geografia moderna, qual seja, a institucionalização e difusão "de conhecimentos cujos interesses práticos para os grupos dominantes da sociedade mais ampla estavam, de modo doutrinário, a serviço da constituição do nacional-patriotismo [...] [e] conquista e (re)conhecimento de territórios e/ou acesso a seus recursos visando possibilidades mais ou menos imediatas de acumulação do capital." (SEABRA, 2004, p. 15) Em segundo lugar, como a AGB-SP reproduziu a própria lógica subjacente à criação da Universidade de São Paulo:

Assim, a par de um projeto voluntarioso de hegemonia cultural e científica, no país,
no caso, especificamente em Geografia, teria a entidade AGB como objetivo
deliberado prover São Paulo - e daí em diante, em particular a industrialização de
São Paulo - de conhecimentos práticos para sua expansão econômica; os dois
"projetos" [acadêmico e prático] sequer seriam necessariamente excludentes, ainda
que, também, não imediatamente e não necessariamente, por completo,
complementares. (SEABRA, 2004, p. 34)

Os indivíduos, do ponto de vista doutrinário, não são apenas aquilo que tem consciência do que são, assim

suas práticas culturais e científicas determinam-se também pelas condições materiais objetivas da época [e, diríamos, do lugar] em que vivem. Assim, a AGB, como "subproduto" da criação da USP, carregaria em si, (in)dependente da vontade de seus membros, esta possibilidade de colocar os conhecimentos que produz, e aos que pretende dar organicidade, também a serviço da expansão econômica do Estado de São Paulo. (SEABRA, 2004, p. 34, grifo nosso.)

A argumentação de Manoel Seabra, a partir de documentação original da AGB-SP, com especial destaque para a passagem acima assinalada, conduz a análise, necessariamente, para uma das maiores conclusões a que se poderá chegar com a presente dissertação, qual seja, a assunção da natureza política do saber geográfico, como um preceito fundador de centros de pesquisa como o $\mathrm{CNG}$, mas também presente em centros, a princípio, fundamentalmente acadêmicos, como o DG-USP. Há claros indícios, reforçados por Backhauser (1942), Ribeiro (2015) e na crítica de Lacoste (2012) à Geografia universitária francesa, quanto à natureza estratégica do saber geográfico, ainda que o controle do conhecimento se distribua de forma desigual entre os atores políticos. 
Há uma dimensão intrinsecamente política em Geografia em que se beneficiam desse saber os grupos mais providos de poder. Nesse sentido, uma Geografia acadêmica com propósitos supostamente desinteressados, ou livres de uma dimensão em que leve em consideração o uso do conhecimento produzido por um determinado grupo, é potencialmente pouco útil ou reprodutora de ideologias geográficas, no sentido proposto por Moraes (2005). Como veremos, as primeiras teses de doutorado defendidas junto ao Departamento de Geografia da FFCL-USP, ainda que procurem ater-se aos aspectos acadêmicos da descrição geográfica, em maior ou menor medida, realizam um efetivo serviço de reconhecimento territorial passível de ser apropriado por agentes econômicos. Via de regra, as considerações econômicas por parte destes primeiros pesquisadores voltam-se ao Estado, embora, como assinalaremos, o desenvolvimento teórico para além da descrição geográfica fosse, em geral, bastante limitado.

Se o projeto era contribuir com a expansão econômica paulista, o conhecimento produzido na AGB não tinha à época, contudo, abrangência para realizá-lo. Esta possibilidade sofreu muito cedo o impacto da ação centralizadora do Estado Novo, da criação do CNG e da fundação do IBGE.

Nem toda a vontade de que estavam imbuídos os fundadores da AGB e seus primeiros sócios poderia competir com tal estruturação centralizada de produção, coleta e organização da informação estatística e geográfica do país que o governo federal estava promovendo. (SEABRA, 2004, p. 35)

Ao que parece, as aspirações da AGB-SP aproximavam-se do que já era realidade, desde 1934, na forma da Secretaria de Estatística Territorial ligada ao Ministério da Agricultura e que seria a raiz do CNG. Soma-se a isso o desejo da AGB de filiar-se à UGI, sendo necessário, para isso, apoiar a criação do CNG. Deve-se considerar ainda o fato de que, se mesmo para os geógrafos do Rio de Janeiro diretamente envolvidos com a fundação do CNG era difícil estimar a proporção que este Conselho adquiriria, para o núcleo paulista, em larga medida distante das aspirações do Poder Central, seria improvável que percebessem a viabilidade de seu "projeto nacional regional" ante a escala de atuação do Estado Novo.

De todo modo, o projeto varguista de promoção da atividade industrial em solo nacional, segundo as condições objetivamente dadas à época, acabou por privilegiar o estado de São Paulo, especialmente a capital e arrabaldes.

Nesse sentido, se o progresso verificado no conhecimento geográfico do território, a partir de meados dos anos 1930 em diante, teve tempo e adequação para ser útil ao "imperialismo paulista", isto seguramente poderia ser muito mais atribuído às consequências das próprias iniciativas do governo federal, através do sistema CNGIBGE, do que, apesar de voluntariosa, de iniciativas da AGB. (SEABRA, 2004, p. 37) 
Alguns temas de pesquisas realizadas por alguns associados, dentro de uma espécie de "programa de pesquisa", foram propostas, no início de 1935, a partir da proposta de divisão regional de São Paulo sob autoria de Pierre Deffontaines, a partir da qual se propôs uma repartição do trabalho a ser realizado. Em agosto do mesmo ano se discutiu o "plano primitivo" de "distribuição desse estudo entre os associados" e, "tomando como base a divisão feita por Deffontaines, fazer pequenas monografias sobre assuntos determinados." A aprovada proposta tratava não apenas de retomar a perspectiva lançada pelo mestre francês "mas, sobretudo a ideia inicial de estudos em conjunto, menos abrangentes, aparentemente mais factíveis". (SEABRA, 2004, p. 52-54)

O limitado alcance econômico e institucional da AGB-SP, todavia, vencido nos primeiros anos pela empolgação de seus fundadores, acabou reforçando sua ligação com o DG-USP. As reuniões dos associados e, delas decorrentes, as publicações, ainda que intermitentes, mantiveram funcionando a Associação nos períodos de maior esvaziamento e dificuldade de captação de verba, ao aprofundarem seu papel de complementaridade à formação e sua importância como divulgadora das atividades acadêmicas e profissionais dos professores do DG, de profissionais de outras áreas - em um período em que os limites institucionais ainda eram pouco claros -, de professores estrangeiros e de alunos. Seabra (2004, p. 39-43), nesse sentido, destaca a forte orientação das palestras que ocorriam na AGB, quase sempre voltadas ou adaptadas à realidade nacional, postura sempre promovida por Pierre Monbeig, por exemplo. Manoel Seabra, em seu trabalho de arquivo, deu-se ao trabalho de elaborar uma lista com a autoria e o tema das palestras realizadas entre 1934 e 1944, a partir da qual é possível perceber-se o engajamento da ciência geográfica que ali se promovia em relação às questões nacionais. Naturalmente, houve um número expressivo de relatos de trabalho de campo e de pesquisas realizadas já há um tempo e por profissionais de áreas afins, de interesse, mesmo assim, ao pensamento geográfico. Vale notar, em seu conjunto, a proximidade temática e uma descontinuidade quanto ao recorte em relação aos materiais publicados na RBG. ${ }^{117}$

Desse modo, também nesses primeiros anos da década de 1940 as pesquisas e os estudos que alimentaram as palestras e os artigos publicados pelos associados da AGB continuaram a relacionar-se essencialmente com as condições oferecidas ou as exigências das atividades dos locais de trabalho dos professores, alunos $e$ quadros técnicos a ela ligados. (SEABRA, 2004, p. 55, grifo nosso.)

\footnotetext{
117 Tal proximidade é aqui expressa apenas como indicativo das preocupações geográficas da época e, em certo sentido, razão de ser da própria Geografia. Uma análise comparativa sistemática, situada além das possibilidades desta dissertação, pode vir a enriquecer a compreensão das preocupações atinentes ao saber geográfico.
} 
O aparente programa de pesquisa que se desenhava, ancorado na "prática sistemática de pesquisas de campo conjuntas como pretendiam seus fundadores e como ainda tentaram reiterar mais de uma vez" ao longo dos primeiros dez anos de existência da entidade, não parece ter frutificado, até por conta da necessidade de cada pesquisador ter de custear sua participação. A AGB-SP não deixou com isso de ser um local privilegiado para a exposição de trabalhos individuais, já que a diversidade de associados possibilitava o debate e crítica dos trabalhos.

Não se pode desconsiderar "que a AGB esteve presente no processo de produção, organização e difusão do saber geográfico pelo país. Pelo menos é o papel que lhe reconhecem vários autores que escreveram sobre sua história ou sobre a história da Geografia no Brasil.” (SEABRA, 2004, p. 38) Mas este papel se fortalece, de fato, a partir de 1945, quando sua estrutura de poder foi mudada e se constituiu uma AGB Nacional, centrada onde foi fundada, responsável pela organização de reuniões, congressos, publicações e constituição de seções regionais e núcleos locais.

\subsubsection{AGB-SP versus AGB-Rio}

Seabra (2004, p. 63) indica que os "estatutos inicias da AGB não previam a existência de núcleos da Associação fora da cidade de São Paulo. Os que moravam fora dela e foram aceitos como associados eram sócios correspondentes, sem a obrigatoriedade de comparecimento às reuniões." Até 1944, houve mais de uma reforma estatutária, cujos conteúdos Seabra não teve acesso. Neste período, há registro de outros três núcleos filiados: Amparo-SP, Curitiba e Rio de Janeiro. Em relação ao núcleo do Rio, há certa polêmica quanto a sua natureza hierárquica com relação à AGB-SP.

Há uma interpretação (VALVERDE, 1992; MACHADO, 2009) de que a AGB carioca, criada também por Deffontaines em 1936, seria independente da se São Paulo, uma segunda AGB. Não há um motivo claro para a fundação de uma segunda AGB por Deffontaines, além das duas hipóteses plausíveis levantadas por Valverde (1992) segundo as quais o mestre francês temeria o desaparecimento da AGB paulista, em decorrência da repressão pós-levante da Aliança Nacional Libertadora, em 1935, ou reproduzia o modelo federativo francês de associação. Segundo Seabra (2004, p. 65), o temor de desaparecimento possui fundamento, em carta de Rubens B. de Moraes a Caio Prado Jr. em 1936 e em Relatório da Associação relativo ao ano de 1940. 
As atas da AGB "paulista" atestam a continuidade dos trabalhos na AGB "carioca", após a saída de Deffontaines em 1938. Valverde (1992) fala da presença de dois grupos de agebeanos - SP e RJ - no IX CBG em Florianópolis. Porém, a partir daí, há uma clara divergência de interpretações. Para Valverde, no período em que a AGB Rio se funde com a AGB São Paulo, em 1943, o núcleo carioca, apoiado pelo $\mathrm{CNG}^{118}$, do qual era uma das cinco associações filiadas, juntamente com a SBG, o IHGB, o Clube de Engenharia e a ABC, estava em plena floração, constituindo-se verdadeiro curso de pós-graduação.

Já nos Anais da AGB relativos ao período 1945-6, apenas o núcleo paulista se encontrava no período em construtiva atividade, Amparo e Rio mantendo "efêmera existência em virtude de diversas circunstâncias". (SEABRA, 2004, p. 65-66)

De qualquer modo, se considerarmos cada uma delas como instrumentos - modestos - dos respectivos "projetos nacionais", uma ligada à USP e outra ao CNG-IBGE e à Faculdade Nacional de Filosofia, não deve ter sido interessante para esta submeterse à uma posição subordinada àquela como núcleo e, para a de São Paulo, quem sabe, sequer reconhecer a continuidade da existência da do Rio de Janeiro. (SEABRA, 2004, p. 66)

A federalização da Associação, com a Reforma Estatutária de 1945, eliminou as barreiras estatutárias referentes ao desdobramento territorial, suprimindo-se a hierarquia entre as futuras seções regionais (mas mantendo a hierarquia entre essas e as seções locais), a partir da criação das duas primeiras: São Paulo e Rio de Janeiro, estruturada em torno de um grupo de sócios efetivos, eleitos pelos próprios sócios mais notáveis de então.

\footnotetext{
118 "Paralelamente à iniciativa de formação de um órgão nacional de Geografia [CNG] por Deffontaines e Monbeig, ou mesmo em retribuição a essa iniciativa, Christóvam Buarque Leite de Castro, que, conforme apontado, era aluno de Deffontaines na UDF em 1936, e Secretário-Geral do CNG em 1937, fornece todo o suporte fundamental, tanto para a AGB [carioca] quanto para a própria Geografia na UDF. Como se pode observar, a Geografia universitária no Rio de Janeiro fez parte de um conjunto de estratégias modernizadoras, estabelecido no país nos anos de 1930. Sua formação foi viabilizada pelas redes de relações pessoais e institucionais montadas principalmente a partir de alguns indivíduos-chave, dos quais Deffontaines merece destaque." (MACHADO, 2009, p. 84, grifo nosso.)

Alentejano (2009) não adentra na polêmica em torno da precedência ou da maior importância de um ou outro núcleo. Sua argumentação, contudo, também reforça a total ligação da AGB-Rio com o CNG, enquanto, como já exposto, a AGB-SP manteve-se ligada fundamentalmente à dinâmica do DG-USP. "A AGB-Rio teve sua história durante longos anos associada ao IBGE [...], criado dois anos depois por Getúlio Vargas e celeiro da 'Geografia Oficial' brasileira, no dizer de Milton Santos. Assim, a AGB-Rio, ainda que informalmente, passou a ter sua sede no IBGE que foi também a base de apoio fundamental para os trabalhos da instituição. Da mesma forma, os principais colaboradores da AGB-Rio em seus primórdios eram os geógrafos ligados ao CNG [...]. A ligação umbilical dos geógrafos cariocas com o CNG/IBGE era tanta que alguns chegam a negar a existência de uma AGB-Rio no período." (ALENTEJANO, 2009, p. 146, grifos nossos.)
} 


\subsection{O PENSAMENTO FRANCÊS NA GEOGRAFIA DA USP}

Tanto Pierre Deffontaines quanto Pierre Monbeig são descritos pela historiografia geográfica como ativos pesquisadores, eruditos, curiosos e participativos. Não resta dúvidas de que ambos não se deslocaram até o Brasil pensando apenas em suas carreiras. ${ }^{119}$ Envolveram-se, antes, com a problemática nacional e conceberam a ciência geográfica como um ramo do saber passível de contribuir com o pensamento e a superação das questões nacionais que se impunham no período. Arriscamo-nos a afirmar que a aplicação do método francês de pesquisa geográfica ao Brasil e, com destaque, as adaptações do modelo à realidade nacional, principalmente por Monbeig, não se deram de forma mecânica e apontam, com efeito, para a potencialidade crítica e política de um ramo de saber cujo valor científico é frequentemente posto em questão.

\subsubsection{Mestre fundador, Pierre Deffontaines}

Pierre Deffontaines chegou ao Brasil, aos 40 anos de idade, ostentando um currículo já sólido, com título de Doutor em Letras pela Sorbonne obtido em 1932, porém, como já exposto, filiado ideologicamente de maneira marginal à corrente majoritária francesa. (SEABRA, 2004) De alma animada, vistoso por ostentar um espírito comunicativo e influente (AB'SÁBER, 2005; ANDRADE, 1994), o mestre francês reuniu em torno de si uma ativa elite pensante na fundação da cátedra de Geografia da USP e da AGB-SP, em 1934. No ano seguinte, uniu sua erudição à de Fernando Antônio Raja Gabaglia e Carlos Delgado de Carvalho no projeto de modernização da ciência geográfica no Brasil, por meio da recémcriada cadeira de Geografia da UDF, além de ter fundado também a AGB-Rio. E dois anos mais tarde, engajou-se nas articulações em torno da criação do CNG. (MACHADO, 2009)

Trouxe consigo a concepção francesa de região então dominante na Geografia e o uso da monografia regional como "método" de investigação. Com ele, o " paradigma' central desta Geografia continuava a ser a relação sociedade/natureza. [...] A outra contribuição de método que Deffontaines trouxe diz respeito à ênfase que dava ao trabalho de campo, stricto

\footnotetext{
${ }^{119}$ Segundo Ab'Sáber (1994, p. 229), Monbeig tinha “a idéia fixa de conseguir recursos para elaborar uma tese sobre as ilhas Baleares, na Espanha. Nunca negou, até o fim da vida, que sua opção pelo Brasil estava respaldada em obter recursos financeiros para poder subvencionar seu trabalho de tese de Estado, sobre as Baleares." Aqui chegando, contudo, foi capturado pela dinamicidade das paisagens regionais brasileiras e, muito cedo, descobriu a importância do tema das zonas pioneiras.
} 
sensu, em Geografia e da excursão como atividade pedagógica relevante de seu ensino." (SEABRA, 2004, p. 29)

Em sua curta estadia em São Paulo, iniciou os estudos para a compartimentação regional do território paulista, à semelhança da divisão regional realizada na França, a partir da qual se poderia proceder com a realização de inúmeras monografias regionais, dentro de um potencial programa departamental de pesquisa.

Digno de nota e comparação é a escala de análise adotada por Deffontaines quando de sua transferência para o Rio de Janeiro, em 1935. Se em São Paulo o geógrafo buscou contribuir com a descrição do território paulista, ao desembarcar no Rio de Janeiro a escala de seu olhar passa a ser nacional e seu compromisso, com a agenda centralizadora de Getúlio Vargas. Na UDF, Deffontaines direcionou "suas atividades em torno de dois grandes objetivos: orientar os futuros profissionais de Geografia quanto ao ofício de professor e desenvolver a vocação de geógrafos exploradores, voltados para o conhecimento do imenso Brasil, ainda mal estudado." (MACHADO, 2009, p. 86)

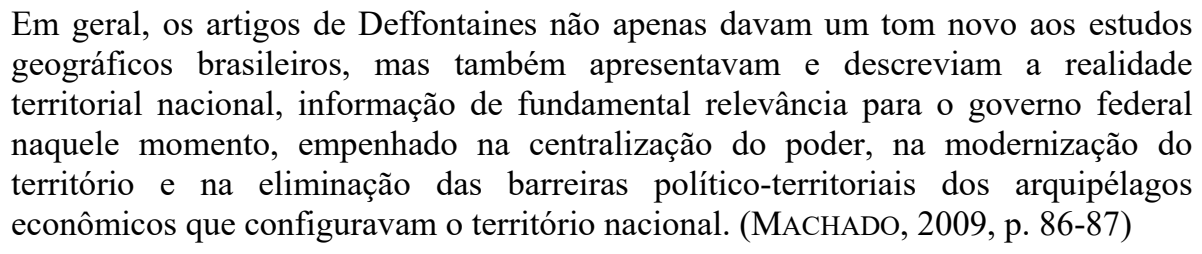

As modernas técnicas lablachianas presentes na obra de Deffontaines atendiam às preocupações e estavam a "serviço de um governo empenhado na centralização do poder, num país até então essencialmente agrário, extremamente segmentado num arquipélago econômico." (GEIGER, 1988, p. 62) Relacionando-se de perto com o CNG, em sua estadia no Rio de Janeiro, e tendo portanto meios efetivos de concretizar suas ambições, o mestre francês apresentou o resultado do esforço de sua "verdadeira estratégia de desvendamento geográfico do Brasil" em um material publicado nos três primeiros números da RBG, "não bem como artigos, mas como partes de um pequeno livro de Geografia Humana do Brasil. Pelo menos assim o entendeu Pierre Monbeig na sua apresentação da Geografia no Manual Bibliográfico de Estudos Brasileiros de Rubens Borba de Moraes e William Berrien”. (SEABRA, 2004, p. 37) Ao que parece, o referido artigo de Deffontaines de fato foi reunido em uma edição ilustrada na forma de livro, destinado à Exposição comemorativa dos Centenários de Portugal. $^{120}$

Para fomentar a ideologia nacional, romper obstáculos à integração espacial, à centralização e à modernização seria necessário um discurso descritivo, a mensuração,

${ }^{120}$ Cf. Revista Brasileira de GeOgrafia, v.2, n. 4, 1940, p. 689. (Bibliografia) 
o controle do território e, também, dividir para reinar, a divisão regional. Não é por acaso que os primeiros números da Revista Brasileira de Geografia iniciam duas séries de artigos: a de Pierre Deffontaines, descrevendo a dimensão continental do Brasil e dando o tom da nova Geografia acadêmica que estava sendo introduzida, a linha vidalina, onde a moldura do quadro natural comanda a organização das atividades humanas; e a de Moacyr F. Silva, focalizando a Geografia dos transportes, o instrumento da integração espacial." (GEIGER, 1988, p. 62-63)

A referida alentada análise de Moacyr Silva, publicada ao longo dos 10 números inicias da $\mathrm{RBG}$, atendia à questão de coesão nacional e difundia no seio do $\mathrm{CNG}$ a perspectiva alemã ratzeliana já disseminada entre os professores de Geografia das escolas secundárias do Rio de Janeiro, “como no Colégio Pedro II, pelos irmãos Raja Gabaglia, Eduardo [sic] Backheuser e Delgado de Carvalho que, embora denominados de geógrafos, eram, contudo, autodidatas, pois não foram formados em academias de Geografia.” (PENHA, 1988, p. 88)

Como se vê, Deffontaines soube engajar-se habilmente em diferentes projetos, o da elite paulista para São Paulo e o de Getúlio Vargas para o Brasil, na promoção dos modernos métodos da Geografia. Tanto o modelo das monografias regionais, quanto o discurso centrado na relação sociedade-natureza, bem como a adoção do método historicista e da prática do trabalho de campo não são, contudo, exclusivos de Deffontaines, sendo adotados também por Monbeig. Segundo Seabra (2004), por mais importante que tenha sido a passagem de Deffontaines por São Paulo, o legado decisivo de um professor de Geografia ligado às missões francesas junto aos cursos de Geografia e História USP foi o de Pierre Monbeig, inclusive por conta de sua longa permanência e seu decisivo papel de formação de toda a primeira leva de professores secundaristas e pesquisadores.

\subsubsection{Jovem promissor, Pierre Monbeig}

Sem a pretensão de realizar uma cobertura do pensamento de Pierre Monbeig, seja pelo número insuficiente de leituras ${ }^{121}$, seja porque este objetivo estaria muito além dos limites do presente trabalho, as considerações a seguir pretendem apenas indicar dois elementos que se tornaram importantes durante a consulta aos textos trabalhados. O primeiro deles é a própria importância das contribuições de Monbeig para o pensamento geográfico, não apenas

\footnotetext{
${ }^{121}$ Nosso objetivo nunca foi analisar o pensamento de Monbeig, em si, daí não realizarmos leitura de textos de sua autoria. A importância de seu pensamento, contudo, adquiriu contornos claros, além de reforçar reflexões anteriores quanto à natureza política do saber geográfico. A respeito da importância do pensamento de Monbeig, vale assinalar que, desde o início do curso de graduação, em 2006, o Prof. Heinz Dieter Heidemann procurou estimular, entre seus alunos, a leitura dos textos do mestre francês. Com grande atraso, corroboramos agora a importância dada pelo professor ao pensamento do mestre francês.
} 
brasileiro, e o potencial teórico da noção de "complexo geográfico", ainda por ser melhor explorada. $\mathrm{O}$ segundo elemento diz respeito à questão mais ampla da importância política da Geografia praticada por Monbeig, que reforça o caráter intrinsicamente político que o saber geográfico aparenta ter.

Pierre Monbeig "chegou a São Paulo muito jovem, com a experiência apenas do ensino secundário, deparando-se com a responsabilidade de substituir um mestre bem mais experiente e dinâmico." (ANDRADE, 1994, p. 73) Impedido de retornar à Europa em decorrência da Segunda Guerra Mundial, permaneceu em São Paulo por 11 anos, ao longo dos quais pôde desenvolver e consolidar o curso de Geografia da USP e expandir em escala nacional a AGB. Sua influência intelectual é inconteste, já que das sete primeiras teses de Geografia defendidas na FFCL-USP - que se tornariam modelos de pesquisa em Geografia para todo o Brasil -, as primeiras quatro foram orientadas por ele, a quinta foi parcialmente orientada por ele e a última, por ex-orientando dele.

Como já afirmado, em 1939 a cátedra única de Geografia desdobrou-se em duas, Geografia Física, ocupada por João Dias da Silveira, e Geografia Humana, ocupada pelo próprio Monbeig até 1946, quando retornou à França, cedendo lugar à Ary França ${ }^{122}$. Em 1942, inaugurou-se a terceira cátedra, de Geografia do Brasil, ocupada por Aroldo Edgard de Azevedo. Ao retorno de Pierre Monbeig para a França, somam-se os primeiros provimentos de cátedra através de concurso público, ao longo da segunda metade dos anos 1940, e a criação do Departamento de Geografia, em 1946, eventos que, juntos, marcaram o primeiro ciclo de fundação do curso de Geografia da USP.

Além dos próprios Ary França e João Dias da Silveira, cujas teses orientadas por Monbeig foram defendidas em 1945 e 1946, respectivamente, o mestre francês constituiu uma equipe de discípulos e auxiliares diretos, dentre os quais Maria Conceição Vicente de Carvalho $^{123}$ e Nice Lecocq Müller. Junto aos doutores formados por Aroldo de Azevedo José Ribeiro de Araújo Filho e Aziz Nacib Ab’Sáber - e também por Elina de Oliveira Santos, orientada por Silveira, Monbeig a esta primeira geração de profissionais se ligou,

\footnotetext{
${ }^{122}$ Segundo relato de Ary França, Monbeig distribuía gradativamente entre seus assistentes a responsabilidade sobre diferentes disciplinas do curso de bacharelado. Ele, França, tornou-se assistente de Monbeig já no período final de estadia do geografo francês no Brasil. Por questões hierárquicas, Maria Conceição Vicente de Carvalho seria a sucessora direta de Monbeig, seguida de Renato da Silveira Mendes. A primeira, contudo, embora se relacionasse muito bem com Monbeig, não tinha tanto interesse pela carreira acadêmica, assim como Mendes, já mais velho e sem a disciplina necessária para fazer carreira. Assim, rapidamente França assumiu o posto de primeiro assistente e estava em condições de assumir o lugar de Monbeig, quando este retornou à França. (FRANÇA, 2005, p. 48-49)

${ }^{123}$ Ao que parece, Monbeig lecionou suas aulas essencialmente em francês por todo o período de permanência no Brasil. "Cabia à professora Maria da Conceição Vicente de Carvalho a tarefa de paralelizar e fazer acréscimos aos temas tratados.” (AB'SÁBER, 1994, p. 222)
} 
"sempre amigo, sempre dedicado, sempre ativo, ajudava, animava e influía [...], não só prestigiando pesquisas e reuniões cientificas como também estreitando, no após guerra, as relações entre este grupo e os centros universitários franceses.” (ANDRADE, 1994, p. 78)

A atuação de pesquisa de Monbeig aliada à sua preocupação pedagógica, ao constituir um modelo de escrita não apenas entre seus discípulos diretos, mas para todo o universo acadêmico-universitário brasileiro, direcionando estudos e consolidando linhas de pesquisa segundo uma unidade conceitual definida, apontam para a rotinização da produção científica da Geografia e para a estruturação de uma explicação especificamente geográfica para diversas questões postas como fundamentais para o país na primeira metade do século XX.

A influência do trabalho de Pierre Monbeig pode ser considerada um marco para a primeira geração de geógrafos formados nas universidades brasileiras, na medida em que "permite diferenciar essa fase da geografia brasileira dos períodos anteriores, marcados pela presença de contribuições isoladas e esparsas que, embora relevantes e passíveis de análise em si mesmas, não chegaram a gerar um sistema orgânico de obras dentro do campo disciplinar." (NOGUEIRA, 2015, p. 3)

Ao concluir seus estudos no período entre-guerras, Pierre Monbeig fez parte da geração formada sob os princípios da chamada "escola clássica" da Geografia francesa, de forte caráter institucional, constituída entorno do pensamento de Paul Vidal de La Blache e que perdurou até o fim dos anos 1970. Esta Geografia se estruturaria com base na "geografia física, desenvolvida por de Martonne e Baulig; no centro, a geografia regional, liderada por Blanchard ou Demangeon; de outro lado, a geografia humana, desenvolvida por Brunhes, Demangeon e Sorre.” (DANTAS, 2009, p. 2)

As primeiras teses de doutorado em Geografia, orientadas pelo próprio La Blache, segundo o modelo monográfico regional inaugurado pelo mestre francês em Tableau de la Géographie de la France (1903), fizeram grande sucesso até 1945 e "correspondiam à necessidade de se dar uma dimensão concreta ao inventário do espaço através de uma descrição minuciosa e tão exaustiva quanto possível dos fatos observados sobre o terreno." (DANTAS, 2009, p. 2)

Antes da Primeira Guerra Mundial a geografia responde, na França, a questões atuais: ela contribui para definir, aos olhos dos franceses, o que é a França; sustenta ou acompanha a expansão colonial; participa do esforço para tornar a economia francesa competitiva como a de outros grandes países - sobretudo a Alemanha. (DANTAS, 2009, p. 2)

A Geografia Regional francesa, estruturada em torno de cinco conceitos básicos densidade, região, meio, gênero de vida e paisagem (CLAVAL, 1996 apud DANTAS, 2009, p. 
15, nota 2) - adquiriu forte teor institucional, também por conta da estruturação política das universidades francesas, que concentravam poder na figura dos ocupantes das cátedras, e relegou à marginalidade inovações teóricas como a Geografia Política de Jacques Ancel, a Geografia Psicológica de Georges Hardy e a obra de Eric Dardel. Até a Segunda Guerra Mundial, mesmo com a perda de espaço junto à opinião pública a partir do entre-guerras, a replicação do modelo de Geografia Regional francês, segundo a abordagem regional e a análise dos gêneros de vida, ainda era capaz de falar, embora de forma crescentemente pitoresca, sobre extensas áreas do território europeu, ainda repleto de paisagens rurais e de permanências constituídas ao longo de extensos períodos de história. A análise regional, para o estudo de realidades locais, associada à análise da situação, para a assinalar a relação entre lugares contíguos, pareciam ser suficientes para a abordagem da Geografia Urbana, da Geografia Política, da Geografia Econômica e da Geografia dos Trópicos. Pierre Monbeig, nesse contexto,

vem para o Brasil com a bagagem simples que os geógrafos, naquele momento, sabiam manejar: o trabalho de campo, a análise regional, a análise de situação. Ele aplica esses conhecimentos no intuito de conhecer e estudar o Brasil. [...]

Estando no Brasil, Monbeig toma consciência dos desafios que se colocam à geografia mais cedo do que se permanecesse na Europa. Ele é sensível à exigência de desenvolvimento que se apresenta no Brasil do Estado Novo: ele mensura o papel das cidades na exploração do espaço brasileiro e é tocado pela rapidez de seu desenvolvimento; percebe que o instrumento que constitui a análise dos gêneros de vida não dá conta do essencial num país de povoamento recente, onde a economia está em reconstrução permanente. (DANTAS, 2009, p. 3)

Do contato com a realidade brasileira em associação às ideias mais fundantes do pensamento de La Blache, às formulações de Cholley sobre a ideia de combinações e aos escritos de Max Sorre, Monbeig oferece importantes avanços em relação às limitações que passa a identificar no instrumental oferecido pela Geografia Regional francesa. ${ }^{124}$ Deste estes, o conceito de complexo geográfico. (DANTAS, 2009)

Em artigo publicado no jornal O Estado de São Paulo, Monbeig (1950) dá pistas de seu entendimento quanto ao objeto da Geografia, embora o texto não seja conceitualmente preciso, talvez por voltar-se ao público amplo, ou porque seu pensamento ainda não estivesse

\footnotetext{
124 "Decerto, a dificuldade em enquadrar uma sociedade em movimento, como ele [Monbeig] qualificava a sociedade brasileira em geral, e a paulista em particular, num estudo regional clássico preocupado com o gênero de vida, mais adequado para descrever as paisagens de longa duração do Velho Continente, não deve mascarar a importância da história e das temporalidades na apreciação que Monbeig faz das movimentações pioneiras dinamizadas com a expansão das plantações de café e algodão (Roncayolo, 2006), já que esse traço da geografia por ele praticada certamente pesa na valorização conferida à história na estruturação das paisagens, ou melhor, na definição dos conteúdos e dinâmicas que as animam." (NOGUEIRA, 2015, p. 5)
} 
plenamente elaborado. ${ }^{125}$ Monbeig (1950) traça um paralelo entre a História e a Geografia e afirma que "um fato histórico não é apenas um fato, mas um conjunto de fatos, cujos elementos não podem ser dissociados sem que se lhes deforme o valor exato.” Assim como o fato histórico, o fato geográfico é constituído por um conjunto de elementos em combinação. "O que acontece com o historiador, repete-se com o geógrafo." Embora não dê indicativos nesse sentido, é possível crer que os elementos constitutivos de um fato geográficos são, em si mesmos, fatos constituídos por outros elementos, numa perspectiva multi-escalar. Tal perspectiva se reforça quando Monbeig se refere a uma cidade como "fato geográfico" e afirma, alguns parágrafos adiante, que a "rede de cidades nas zonas novas do Estado de $\mathrm{S}$. Paulo mostra bem o que é um complexo geográfico."

Numa das passagens decisivas de seu artigo, afirma o geógrafo:

Costuma-se dizer que a geografia se esforça por definir, localizar e explicar as
diferentes paisagens da terra. [...] Uma paisagem é um fato geográfico: falamos da
paisagem do café, da paisagem industrial. Facilmente nos inteiramos de que esse
fato é mais complicado ainda que o fato urbano. É exatamente um complexo, em
que entram elementos físicos, biológicos e humanos. (MonBEIG, 1950, p. 4)

Nessa passagem, Monbeig afirma que a paisagem é um fato geográfico, embora de maior complexidade. É, por isso, também, um complexo. Paisagem, fato geográfico e complexo geográfico são tomados como sinônimos, embora, em outra publicação, o autor diferencie os conceitos:

A paisagem não exterioriza todos os elementos constituintes do complexo. [...]
Outro perigo - a limitação do campo de estudo à paisagem ameaça levar o
pesquisador ao recurso exclusivo da descrição. [...] A paisagem é o ponto de partida,
mas não um fim. Resulta do complexo geográfico, sem confundir-se com ele.
(MONBEIG, 1957, p. 11)

Monbeig (1950) fala, ainda, na "complexidade de parcelas que, reunidas, constituem uma combinação geográfica”. O conceito francês de combinação, também aparece associado, quase como sinônimo, à noção de complexo geográfico. O fato é que o autor não dá uma definição direta à noção e as análises de Dantas (2009) e Vitte (2011) também não o fazem, apesar da bibliografia citada por ambos.

Apesar disso, a noção de "complexo geográfico" atraiu nossa atenção porque Pierre Monbeig parece atribuir à paisagem a dimensão material de totalidades irredutíveis segundo a divisão disciplinar dos saberes. "O trabalho do geógrafo é, pois, evidente: o problema que

125 Praticamente todos se referem a Monbeig como um profissional em constante atividade. Não temos, infelizmente, bibliografia suficiente para explorar com a necessária profundidade sua noção de "complexo geográfico". Seus dois textos consultados a respeito do assunto não aprofundam muito em termos teóricos e, além disso, as breves análises de Dantas (2009) e Vitte (2011) não convergem, indicando margem para o debate e pontos a serem melhor explorados. 
incessantemente se lhe apresenta é o de decifrar esse complexo.” (MONBEIG, 1950) O autor parece valorizar todos os elementos que concorrem para a composição de um complexo geográfico - e sua respectiva paisagem -, fato muito evidente em algumas teses defendidas junto ao DG-USP - daí, inclusive, a impossibilidade de tomar como sinônimos "complexo geográfico" e "paisagem", já que nem todos os elementos do complexo são do âmbito do aparente, mas podem concorrer para a composição da paisagem.

Apresso-me a acrescentar que o homem não vive nem age em abstrato. Ele é inseparável de seu meio. Grande mérito da geografia é o de lembrá-lo sem sessar e de trazer assim à realidade os espíritos abusivamente metafísicos. O geógrafo tem pés na terra: deve ali mantê-los solidamente plantados, sob pena de perder sua própria razão de ser e falhar a seu papel. Mas a vida coletiva não se organiza somente em função das condições naturais, nem a valorização da terra se faz unicamente sob injunções do meio físico. Tanto quanto em função das possibilidades do meio, as maneiras de viver das sociedades se organizam em função das estruturas internas, dos interesses econômicos, das capacidades técnicas e dos hábitos mentais. E estes últimos não são o menor fator. [...] Pode-se perguntar, porém, se a geografia humana não pecou por excesso de prudência ou por temor de abordar problemas para os quais se sentia mal armada. Porque as ideias levam os homens mais longe do que os caminhos naturais. (MONBEIG, 1950, p. 4)

A interessante passagem acima explicita o compromisso da Geografia com um dada ordem tópica - com uma dada geografia -, sem, contudo, prescindir de fatores não-materiais que concorrem para a composição desta ordem, cuja paisagem é a dimensão aparente e a própria razão de ser do geógrafo. Nesse sentido, no estudo da paisagem de certas regiões, o estudo de personalidades individuais ou de individualidades deve ser considerado, em nome do rigor científico. Segundo Monbeig (1950), a "mera relação de forças sobre a natureza e o homem", na qual se atribui ação determinante do meio sobre o homem, não dá conta da existência do complexo, pois não se reconhece que "a atividade produtora dos homens tirava partido das possibilidades naturais, segundo suas necessidades e suas técnicas." O ponto de vista geográfico continua sendo sua especificidade frente a historiados e economistas, embora deva analisar também a "estrutura do meio humano", assim como o fazem a sociologia e a psicologia.

Assim, no estudo dos complexos geográficos, Monbeig não leva em consideração apenas a relação de uma da sociedade com uma dada natureza, mas a relação estabelecida entre os lugares e também interesses subjetivos na apropriação da natureza pelos homens.

Deste compromisso com a realidade em sua complexidade, podemos estabelecer um claro paralelo com um limite teórico observado também nos materiais publicados na Revista Brasileira de Geografia, ainda que esta limitação deva ser relativizada. Do engajamento aos respectivos "projetos nacionais" paulista e nacional (SEABRA, 2004), a Geografia de matriz francesa desenvolvida tanto em São Paulo quanto no Rio de Janeiro encontrou condições 
concretas para desenvolver-se e produzir conhecimento segundo o ponto de vista geográfico. Quando associamos a fala de Monbeig sobre a "atividade produtora dos homens" a tirar partido das "possibilidades naturais, segundo suas necessidades e suas técnicas" (grifo nosso), à leitura cartográfica da ordem tópica da realidade presente nos primeiros trabalhos publicados junto ao CNG e ao DG-USP, pode-se reiterar a hipótese de que esta primeira geração de geógrafos estava próximo de apreender, segundo uma perspectiva cartográfica, um dado propósito capitalista na apropriação da natureza pela sociedade e uma respectiva ordenação das coisas sobre o território, seja paulista, seja nacional. Reiteramos, a possibilidade de crítica à apropriação do território sob lógica capitalista a partir dos princípios derivados da localização das coisas sobre o território não chegou a ser realizada, talvez, porque a ciência geográfica do período não se prestasse a isso mas, antes, à própria possibilidade de avanço das forças produtivas lideradas pelo Estado, não fazendo pois, sentido, uma crítica à dimensão geográfica desta empreitada. Desta consideração, contudo, deve-se destacar o segundo elemento de destaque, a partir da leitura das teses de doutorado defendidas junto ao DG-USP e da influência do pensamento de Pierre Monbeig sobre o pensamento geográfico brasileiro, a saber, o caráter político e engajado do saber geográfico.

\subsection{DIMENSÃO POLÍTICA DO SABER GEOGRÁFICO}

Quando se fala no estudo científico de uma dada ordem tópica estabelecida a partir das atividades produtivas de uma determinada sociedade sobre um ambiente natural, segundo suas necessidades e suas técnicas, pode-se questionar tanto a finalidade de tais estudos, quanto a natureza dessas necessidades que presidiriam a atividade produtora humana.

O professor, engenheiro especializado geólogo e geógrafo Everardo Backheuser chama a atenção pela perspicácia com a qual, ainda em 1942, identifica dois modos diferentes de se encarar o produto da reflexão geográfica: seja como fato meramente geográfico, seja como fato político. Sua contribuição emergiu de artigo publicado na Revista Brasileira de Geografia, com o fito de especificar os campos de atuação da Geopolítica e da Geografia Política. De um mesmo conhecimento factual produzido pela ciência geográfica sobre uma determinada extensão de área da superfície terrestre pode-se extrair tanto conclusões de natureza especificamente científica quanto objetivos políticos de interesse estatal. Dos estudos realizados pela Geografia Política, restritos a um grupo delimitado de questões, pode 
assenhorar-se o Estado destas informações e refleti-las à luz de sua conveniência, colocandose, assim, outras questões, do âmbito da Geopolítica.

A mesma questão teórica de "espaço", o mesmo fato prático de "domínio", pode ser visto de dois modos: já como questão (ou fato) político, e estará no raio da geopolítica, já como questão (ou fato) meramente geográfico, e o estudá-lo caberá à geografia política. [...]

Assim, pois, do mesmo princípio teórico de "espaço" a geografia humana estabelece umas tantas conclusões gerais, e a geopolítica deduz outras tantas consequências. São campos confrontantes, assaz próximos, e todavia diferentes. (BACKHEUSER, 1942, p. 32/35)

Apoiando-se em razões etimológicas, Backheuser (1942, p. 22), a partir do criador do termo, Rudolf Kjellén (1916), afirma que “'Geopolítica é a política feita em decorrência das condições geográficas.’. E, portanto, que: ‘Geopolítica não é parte ou capítulo ou parágrafo da ciência Geografia, mas da ciência Política’." 126 Kjellén teria criado outros ramos para o estudo do Estado, embora, diferentemente da Geopolítica, tenham caído no esquecimento. Backheuser (1942, p. 26) elenca alguns motivos que explicariam o enorme sucesso do termo, dentre os quais, a adoção do mesmo pelos geógrafos, pois "ambas, geografia e geopolítica, se apóiam nos mesmos resistentes princípios de 'espaço' e 'posição' da doutrina de Ratzel." Kjellén, que não era geógrafo, ao desejar firmar as bases telúricas da política,

teria sopesado as várias teorias reinantes no campo da geografia e, verificando que a de Ratzel era aquela que apresentava melhor estrutura científica, tomou-a para guia de sua construção política, pondo, assim, em pé de igualdade, quanto aos fundamentos essenciais, geografia humana e política com geopolítica. (BACKHEUSER, 1942, p. 26)

Backheuser (1942) procura manter-se fiel às formulações originais de Kjellén, segundo o qual a base geográfica seria essencial à Política, mas a Geopolítica, oriunda deste contato filosófico, é apenas um dos ramos daquela, embora o mais importante. Assim, busca evitar o entendimento de que a Geopolítica nada mais seria do que uma Geografia Política aplicada, segundo a definição de um célebre estudioso no assunto, Otto Maull. Mais ainda, busca repelir a influente definição de seu principal divulgador, Karl Haushofer, em cujo papel de fundador e diretor da publicação Zeitschrift für Geopolitik, a Geopolítica assume a responsabilidade de fornecer as técnicas para a política prática e "deve se tornar a consciência

\footnotetext{
126 “[...] Mais sensata é a abordagem de Michael Heffernan: uma vez que as relações entre Geografia e poder já existiam sob o rótulo geografia política, a emergência do termo Geopolitik (localizada por ele em 1899, tendo como parâmetro o próprio Kjellén) é uma questão de terminologia. Aliás, sua interpretação sobre o surgimento da geopolítica é muito original: mais que simbolizar a glória dos Impérios europeus, a geopolítica representa o sentimento de uma ampla mudança na ordem mundial, definida pelo declínio da Europa no início do século XX e pela progressiva força internacional dos Estados Unidos da América (HEFFERNAN, 2000). [...]” Nesse sentido, Friedrich Ratzel, Alfred Mahan e Halford Mackinder podem ser considerados geopolíticos. (RIBEIRO, 2015, p. 49, nota 19)
} 
geográfica do Estado." Segundo a proposta do grupo em torno de Haushofer, desconsidera-se claramente os outros ramos da Política e se torna a Geopolítica um instrumento e guia para a atividade política, já que dentro da evolução desta o "solo" se torna elemento predominante.

Porém, a despeito da problematização de Backheuser e da validade em si do debate por ele proposto, o fato é que as considerações geopolíticas de interesse estatal partem dos conhecimentos produzidos no âmbito da própria ciência geográfica. Assim, Backheuser é levado de modo muito clarividente, seja pela perspicácia, seja pela antecipação a críticas como a de Yves Lacoste, a afirmar:

Há monografias que mau grado se dilatarem por algumas dezenas de páginas em descrições geográficas são legítimos ensaios de geopolítica. A apresentação da paisagem geográfica, natural e cultural, é apenas introdução a conclusões de ordem política. São elas, portanto, monografias geopolíticas. (BACKHEUSER, 1942, p. 35, grifo nosso.)

Embora as questões colocadas pela Geopolítica não possam se confundir com questões do âmbito da Geografia Política, é o próprio conhecimento geográfico que interessa ao Estado e sobre o qual este se debruçará no movimento de apropriação territorial. Ora, a análise regional francesa trazida na bagagem por Pierre Deffontaines e Pierre Monbeig se prestava, também, justamente à produção de inventários descritivos que atenderiam à necessidade de apropriação do território pelo Estado. Repetimos a argumentação de Ribeiro (2015, p. 50), segundo a qual os mais eminentes geógrafos franceses, dentre os quais Paul Vidal de La Blache, Albert Demangeon, Lucien Gallois, Emmanuel de Martonne e Jean Brunhes, prestaram-se a semelhante papel desempenhado por seus pares alemães, já que "não só eram partidários do colonialismo como emprestaram sua expertise ao governo francês no escrutínio e na reorganização das fronteiras territoriais durante e após a Primeira Guerra Mundial”. Daí ser ficcional a tese que rotulou esta geração de geógrafos franceses como empirista no campo epistemológico e ingênua no terreno político.

Nesse sentido, não é exagero afirmar que a bagagem teórico-metodológica de Pierre Monbeig associada às questões políticas e econômicas em pauta no Brasil da Era Vargas e desenvolvida por ele e pela equipe de pesquisadores em torno dele fornece uma possibilidade de participação da ciência geográfica no debate político e social em curso no país naquele período, tanto no âmbito acadêmico, quanto na prestação de serviços à necessidades de informações territoriais do Estado e do grande capital privado. A análise das primeiras teses de doutorado defendias junto ao DG-USP, nesse sentido, pode contribuir, também, com a compreensão do pensamento do geógrafo estrangeiro que mais tempo permaneceu em atividade no Brasil. 


\subsubsection{Efetiva apropriação do saber geográfico pelo Estado}

Em que pese a importância geopolítica atribuída por Backheuser às monografias regionais, validada ao menos por passagens das teses de doutorado de Araújo Filho (1950), Carvalho (1944), Santos (1999) e mesmo por Silveira (1948), permanece o questionamento, levantado junto aos materiais publicados pela RBG, acerca da efetiva maneira por meio da qual o Estado se apropriaria dos conhecimentos produzidos à luz da ciência geográfica, tal como expostos nas publicações.

Gregório Bondar (1950), vinculado ao Instituto Biológico da Bahia, por exemplo, é o autor do relatório de viagem intitulado As possibilidades econômicas do centro do Estado da Bahia ${ }^{127}$, publicado na seção "Comentários" da RBG. Este relatório, cuja finalidade é o reconhecimento territorial do vale do rio Utinga, no estado da Bahia, como tantos outros materiais publicados na RBG, possui clara motivação econômica. Previsto para tratar-se de levantamento geobotânico, por força do recorte espacial da bacia hidrográfica do referido rio, o estudo de Bondar foi ampliado com vistas à geologia e às possibilidades econômicas dos municípios vizinhos, compreendidos no âmbito dessa bacia.

O relatório de viagem apresenta estrutura similar a diversos outros materiais de maior extensão e que apresentam evidente recorte regional. Guarda, porém, certo pragmatismo incomum aos estudos que pretendem descrever a paisagem regional, talvez por ter finalidades bastante claras. De maneira objetiva, o autor apresenta o itinerário da viagem, fazendo apontamentos quanto à geologia e às cotas altimétricas dos pontos de referência. Sua exposição, a seguir, obedece à leitura sintética que traça do conjunto do problema:

A hidrografia dessa vasta região, suas reservas d'água, possibilidades de saneamento, e aproveitamento econômico na agricultura, decorrem do conjunto geológico, topográfico e demográfico. (BONDAR, 1950, p. 616)

Bondar sempre submete sua avaliação de aspectos naturais da região estudada à possibilidade de aproveitamento econômico, no caso, especialmente à possibilidade de construção de uma barragem em determinado ponto do rio. Também há espaço para considerações de ordem político-econômica, quando se aborda o aspecto fundiário da questão demográfica:

\footnotetext{
127 BondAR, Gregório. As possibilidades econômicas do centro do Estado da Bahia.. Revista Brasileira de Geografia, v. 12, n. 4, 1950, p. 614-620. Apesar do recorte nitidamente regional e da estrutura de relatório de campo, devido às motivações e preocupações apresentadas classificamos o material como pertencente à área de GEOGRAFIA ECONÔMICA.
} 
O estado, para incentivar a produção, cogita da introdução de algumas famílias de colonos estrangeiros e contempla a evasão de milhares de homens válidos nacionais, aos quais faltam os mínimos recursos para se estabelecer como lavradores na imensidão de ótimos solos incultos, no centro do estado. (BONDAR, 1950, p. 618)

O autor, por fim, avalia a viabilidade de uma série de culturas agrícolas e, como consideração final, avalia a possibilidade de se represar o rio Utinga em outro ponto de seu curso, em relação à proposta em análise, e lista uma série de vantagens a este respeito.

É válido salientar que a expedição empreendida por Bondar obedece ao cumprimento da Lei Estadual n. 36, de "Planejamento de aproveitamento econômico do vale do rio Utinga, empreendendo obras de saneamento, estímulo à produção regional e facilidade de transportes, de modo a fixar a população e promover o desenvolvimento da região". (BONDAR, 1950, p. 614) Trata-se, pois, de um típico trabalho de reconhecimento territorial, uma das principais atribuições vinculadas ao labor geográfico, porém, com uma objetividade incomum aos estudos geográficos. Teria, de todo modo, o Estado efetivamente se apropriado do levantamento produzido por Gregório Bondar?

É de se questionar, inclusive, se ao secretário da agricultura Dr. Nestor Duarte, autor da portaria que solicitou o estudo, encaminhou-se o relatório de viagem publicado na RBG, ou outro documento, eventualmente mais técnico.

Publicações independentes sobre questões específicas, patrocinadas pelo IBGE, que fogem ao escopo direto da RBG, exerceriam mais claramente a função da Geografia no corpo estatal? Ou ainda, a publicação de artigos no âmbito da RBG obedeceria a uma perspectiva de divulgação científica e possibilidade de diálogo com a comunidade acadêmica ou seria apenas a versão ensaística de materiais técnicos, em alguma medida pouco acessível à sociedade civil, destinado aos agentes estatais e ao grande capital privado?

Uma importante consideração a ser feita reside na diferença de finalidade entre os materiais publicados pela RBG e as teses defendidas junto ao DG-USP. Enquanto os materiais publicados pela Revista emergiram de um Conselho vinculado diretamente ao Gabinete da Presidência e criado com finalidade de servir às ambições territoriais estatais, os cursos universitários de Geografia, ao menos de maneira não explícita, não tinham como primeira finalidade vincular-se a estas aspirações. Se o fazem, é porque o conhecimento geográfico guarda, em si mesmo, um potencial geopolítico estratégico explicitado ao menos por Yves Lacoste e Everardo Backheuser e também porque já está historicamente vinculado ao trabalho do geógrafo a possibilidade de auxílio à administração pública. 
O insistente questionamento, porém, relativo ao efetivo aproveitamento pelo Estado das informações de natureza territorial produzidas pela ciência geográfica moderna ganhou corpo ao longo da análise dos diversos materiais consultados. Uma hipótese é a de que, embora gozasse de "grande prestígio" junto ao Governo Federal pelo menos até os anos 1950 (MACHADO, 2009, p. 139), principalmente em função de seu trabalho de reconhecimento das potencialidades de regiões próximas às frentes pioneiras, a Geografia brasileira viu seu poder consultivo diminuído frente à necessidade de análises econômicas e sociais relativas a projetos de intervenção territorial sobre áreas urbanas e regiões históricas refuncionalizadas pelo avanço do capital industrial, para as quais não estava preparada. Daí a possibilidade de que o Estado deixou de voltar-se à Geografia apenas a partir de determinado momento. De todo modo, a Geografia, até determinado momento, teria atuado no sentido de reconhecer territorialmente o país, já que na maior parte dos trabalhos consultados a análise geográfica parece descrever totalidades, carecendo os estudos das paisagens regionais de elementos técnicos e quantitativos suficientes para a ação da planificação estatal. Estes dados seriam levantados em um segundo momento por outras especialidades.

A segunda hipótese é a de que, reconhecida a necessidade e a potencialidade de estudos territoriais e financiados tais estudos, as limitações da realidade periférica do capitalismo brasileiro impediu que o Estado aproveitasse pelo menos a maior parte do conhecimento geográfico produzido.

Como desdobramento das duas hipóteses consideradas, admitimos a proposição de que do vínculo da Geografia com o Estado, em função do interesse estratégico sobre a dimensão política do saber geográfico, o ambiente propício à reflexão acabou sendo mais benéfico ao próprio desenvolvimento teórico da Geografia do que ao aproveitamento prático por parte do Estado, que financiou empreitada geográfica. Esta proposição parece ser reforçada quando se leva em consideração os esforços conscientes que a comunidade constituída em torno da ciência geográfica empreendeu para sua institucionalização, não apenas no plano do desenvolvimento material, mas também na aprovação de leis, resoluções e decretos que beneficiaram diretamente a prática do saber geográfico em solo brasileiro. 


\subsection{AS PRIMEIRAS TESES DE GEOGRAFIA DO BRASIL}

A análise relativa à produção acadêmica no âmbito do DG-USP baseou-se nas teses de doutorado defendidas junto ao Departamento, dentro do período considerado pela pesquisa, a partir das listas de defesas publicadas no site do mesmo. ${ }^{128}$

As referidas listas identificam nove defesas de doutorado entre a primeira, ocorrida em 1944, e 1956. (TABELA 1)

TABELA 1 - PRIMEIRAS TESES DE DOUTORADO DEFENDIDAS JUNTO AO DG-USP *

\begin{tabular}{|c|c|c|c|c|}
\hline & AUTOR & ORIENTADOR & DEFESA & Título \\
\hline 1. & $\begin{array}{l}\text { Maria da Conceição } \\
\text { Vicente de Carvalho }\end{array}$ & \begin{tabular}{|l|} 
Pierre \\
Monbeig \\
\end{tabular} & 23.11 .1944 & $\begin{array}{l}\text { Santos e a Geografia Humana do } \\
\text { Litoral Paulista }\end{array}$ \\
\hline 2. & Ary França & \begin{tabular}{|l|} 
Pierre \\
Monbeig
\end{tabular} & 16.11 .1945 & $\begin{array}{l}\text { Estudo sobre clima da bacia de São } \\
\text { Paulo }\end{array}$ \\
\hline 3. & João Dias da Silveira & \begin{tabular}{|l|} 
Pierre \\
Monbeig \\
\end{tabular} & 1946 & $\begin{array}{l}\text { Estudo geográfico dos contrafortes } \\
\text { ocidentais da Mantiqueira }\end{array}$ \\
\hline 4. & Nice Lecocq Muller & $\begin{array}{l}\text { Pierre } \\
\text { Monbeig }\end{array}$ & 22.11 .1946 & Sítios e sitiantes \\
\hline 5. & Renato da Silveira $^{(\mathbf{1})}$ & \begin{tabular}{|l|} 
Pierre \\
Gourou (2)
\end{tabular} & 1948 & $\begin{array}{l}\text { Paisagens culturais da Baixada } \\
\text { Fluminense }\end{array}$ \\
\hline 6. & $\begin{array}{l}\text { Renato Silveira } \\
\text { Mendes (1) }\end{array}$ & $\begin{array}{l}\text { Pierre } \\
\text { Monbeig }\end{array}$ & 23.10 .1948 & $\begin{array}{l}\text { Paisagens culturais da baixada } \\
\text { santista }\end{array}$ \\
\hline 7. & $\begin{array}{l}\text { José Ribeiro de } \\
\text { Araújo Filho }\end{array}$ & \begin{tabular}{|l|} 
Aroldo de \\
Azevedo \\
\end{tabular} & 06.06 .1950 & A baixada do Rio Itanhaém \\
\hline 8. & $\begin{array}{l}\text { Elina de Oliveira } \\
\text { Santos }\end{array}$ & \begin{tabular}{|l|} 
João Dias da \\
Silveira \\
\end{tabular} & 23.04 .1951 & $\begin{array}{l}\text { A industrialização de Sorocaba: } \\
\text { bases geográficas }\end{array}$ \\
\hline 9. & Aziz Nacib Ab’Sáber & $\begin{array}{l}\text { Aroldo de } \\
\text { Azevedo }\end{array}$ & 27.11 .1956 & $\begin{array}{l}\text { Geomorfologia do sítio urbano de } \\
\text { São Paulo }\end{array}$ \\
\hline
\end{tabular}

* Os "Índices" das teses consultadas podem ser consultados no "ANEXo D".

$\checkmark$ Teses consultadas na presente dissertação.

(1) Conforme registro presente nos sítios eletrônicos indicados.

(2) Pierre Gourou assumiu a orientação após Pierre Monbeig retornar à França, em 1946. (CONTI, 2014)

A similaridade das teses n. 5 e n. 6 indicadas na Tabela 2 causam estranhamento. De fato, não foi identificada, em nenhuma fonte de pesquisa, nem mesmo em pesquisas abrangentes por referências na internet, a existência da tese n. 6, "Paisagens culturais da baixada santista", sob autoria de Renato Silveira Mendes [sic] e orientação de Pierre Monbeig. Já a tese n. 5 foi encontrada e sua publicação, em 1950, foi a versão consultada por nós.

${ }^{128}$ Cf. $<$ http://www.geografia.fflch.usp.br/posgraduacao/teses_GH.htm $>$ e $<$ http://www.geografia.fflch.usp.br/po sgraduacao/teses_GF.htm>. Último acesso em 13 de janeiro de 2015. 
No presente item, assim como no restante da dissertação, tomamos a difícil e arriscada decisão de não fazer referências à tese de Ary França, Estudo sobre clima da bacia de São Paulo, e à tese de Aziz Nacib Ab'Sáber, Geomorfologia do sítio urbano de São Paulo, pois, embora a importância de ambas seja inconteste, as referências a elas, ainda que revelassem mais aspectos de interesse à nossa análise, não alterariam essencialmente as considerações finais a que poderíamos chegar com o presente trabalho. Semelhante decisão foi tomada com numerosos materiais publicados na RBG. Considerações e justificativas a este respeito podem ser apreciadas nas "Considerações Finais".

No sub-item a seguir, antes da análise das teses consultadas, ressaltamos um aspecto que teria presidido, em alguma medida, os recortes regionais das primeiras teses defendidas junto ao DG-USP. Embora tenhamos tão-somente apontado um debate possível de se ser realizado, trata-se de um aspecto digno de nota.

\subsubsection{As divisões regionais de Deffontaines e Monbeig}

Como já afirmado, logo que chegou a São Paulo Pierre Deffontaines iniciou os estudos para a compartimentação regional do território paulista, à semelhança da divisão regional realizada na França. Seu trabalho Regiões e Paisagens do Estado de São Paulo (1945) ${ }^{129}$ poderia orientar a realização de inúmeras monografias regionais, dentro de um potencial programa departamental de pesquisa.

Além da proposta de Deffontaines, Pierre Monbeig também publicou uma proposta de divisão regional intitulada A divisão Regional do Estado de São Paulo $(1946)^{130}$ e, juntos, os trabalhos parecem ter influenciado o recorte regional dos primeiros trabalhos defendidos junto ao DG-USP. Ambos propuseram uma divisão regional para o Estado de São Paulo, que orientariam a priori futuras pesquisas em geografia regional.

O trabalho do professor Deffontaines é a primeira tentativa científica de divisão
regional do Estado que se faz entre nós. Será inútil encarecer a utilidade de um tal
estudo: a divisão regional é um primeiro passo necessário em qualquer estudo sério
de Geografia local, uma base imprescindível para o conhecimento geográfico de um
país. A falha até hoje existente neste terreno era sensível e tornava quase impossível
uma compreensão verdadeiramente científica do nosso Estado. O professor

129 Deffontaines, P. Regiões e Paisagens do Estado de São Paulo. Boletim Geográfico, v. 2, n. 24, p. $1837-$ 1850; v. 3, n. 25, p. 18-27, 1945. Publicado originalmente nos Annales de Géographie, n. 253, jan. 1936. Trad. de Orlando Valverde.

${ }^{130}$ Monbeig, Pierre. A divisão regional do estado de São Paulo. (Relat. apres. à Assembleia Geral da AGB, reunida em Lorena (1946), em nome da Sec. Reg. São Paulo. Anais da Associação dos Geógrafos Brasileiros, v. 1 (1945-1946), p 19-36, 1949. Este trabalho sequer foi consultado por nós. 
Deffontaines, que em 1934 regeu a cadeira de Geografia da Universidade de São Paulo, com sua dupla experiência de cientista e professor sentiu-a muito bem, e não quis deixar o nosso país sem antes prestar mais êste serviço à causa da Geografia nacional. [...] (DEFFONTAINES, 1945, p. 1837. Nota da Redação.)

A influência relativa de ambos os trabalhos sobre as teses analisadas carece de investigação, mas a perspectiva de realização de numerosas monografias regionais sobre o Estado de São Paulo, ao estilo francês, formando mesmo, quiçá, um Programa de PósGraduação, parece bastante claro. Essa leitura fortalece a hipótese de que o Departamento de Geografia da USP orientava suas preocupações eminentemente para São Paulo.

Em relação aos artigos dos mestres franceses, frente à necessidade de análise pormenorizada situada além da perspectiva do presente trabalho, restringimo-nos a destacar, dentre outros aspectos de fato relevantes, a "monotonia" experimentada por Deffontaines ao encarar o território paulista, que lamenta: “As cartas não indicam nenhum nome regional, isto é, nenhum nome de paisagem, análogo por exemplo às nossas Beauce, Brie, Morvan.” (DEFFOnTAINES, 1945, p. 1837) E continua:

Donde provém esta dificuldade especial de destacar diferenças regionais? É o homem, mais que a natureza, que cria a paisagem, é êle que constitui sobre a terra estas vestimentas particulares que fazem nascer os nomes de regiões. No Brasil Meridional, o homem ainda não se ligou bastante à terra, não há nomes de regiões e tampouco de paisagens especializadas porque não se formaram ainda verdadeiros "homens da terra", as paisagens não estão acabadas. (DEFFONTAINES, 1945, p. 1837)

O geógrafo francês procura, primeiramente, em fatores da natureza, critérios para uma divisão regional, mas se depara com nomes imprecisos em relação aos tipos de solo e às formações vegetais. O regime instável de explotação da terra pelo homem, diretamente relacionada à baixa fixidez da população, também contribuem para a dificuldades de aparecimento de nomes de regiões.

\footnotetext{
O país ainda não descobriu uma economia estável, fixadora do homem, que permita a lenta elaboração de uma paisagem. [...]

As divisões regionais acham-se aqui ainda totalmente na infância. Na falta de melhor, adotou-se a divisão arbitrária criada pelas companhias de estrada de ferro e fala-se correntemente na zona da Central, da Paulista, da Sorocabana, da Noroeste, faixas de território que cobrem as regiões mais disparatadas e que não podem absolutamente fazer as vêzes de divisões naturais. (DEFFONTAINES, 1945, p. 1838)
}

Segundo critérios eminentemente naturais ou em função do maior ou menor desenvolvimento econômico do homem rural, cujo trabalho ainda não foi capaz de criar paisagens, Deffontaines propõe, segundo a síntese de Conti (2014, p. 243), uma macrodivisão regional: Litoral, Zona cristalina, Depressão periférica e Planalto arenítico-basáltico do oeste, além de duas ou três subdivisões internas para cada região. 
Do exposto em relação à proposta do mestre francês, cumpre-nos, apenas, questionar o fundamento teórico-metodológico de uma divisão regional a priori, tendo em vista a perspectiva fortemente indutivista das pesquisas da época, ancoradas na observação e na descrição de paisagens. Trata-se da constatação da crítica ao conceito tradicional de região segundo a qual, na análise da paisagem, deveria haver questionamento quanto ao que é próprio da realidade e o que é próprio da observação do pesquisador. A divisão regional de Deffontaines para o estado de São Paulo parece mesmo assimilar-se à proposta de Paul Vidal de La Blache para o território francês, ao menos a partir da leitura crítica de Yves Lacoste.

O cerne da crítica do famoso livro de Lacoste (2012) ao que chama de "regiãopersonagem" parece estar, mesmo, justamente nessa "maneira de recortar a priori o espaço num certo número de 'regiões', das quais só se deve constatar a existência, essa forma de ocultar todas as demais configurações espaciais". (LACOSTE, 2012, p. 63)

Segundo Lacoste (2012), em seu Quadro da geografia da França (1905) La Blache teria ensinado aos franceses e ao mundo como se fazer "geografia por excelência", através da descrição de paisagens historicamente constituídas de fatores naturais e humanos. Privilegia, contudo, "as permanências", banindo "tudo que decorre da evolução econômica e social recente, de fato, tudo o que tinha menos de um século e traduzia os efeitos da 'revolução industrial'." (p. 57/58) Sua concepção de homem-habitante expulsa para fora "da reflexão geográfica o homem nas suas relações sociais, e com mais forte razão ainda, nas relações de produção." Daí La Blache falar pouco sobre cidades, em especial a cidade moderna, metropolitana. O procedimento de descrição de um certo número paisagens identificadas na realidade - "individualidades", "personalidades" - como representativas de um país “impregna, hoje, todo o discurso sobre a sociedade, toda a reflexão econômica, social e política" (p. 59). "É um dos obstáculos capitais que impedem de colocar os problemas da especialidade diferencial, pois admite-se, sem discussão, que só existe uma forma de dividir o espaço.” (LACOSTE, 2012, p. 59-60)

$\mathrm{Na}$ maioria dos casos, as configurações espaciais de diferentes grupos de fenômenos identificados e categorizados pelo pensamento, de um mesmo lugar, não coincidem umas com as outras, mas formam uma série de interseções complexas. "Uma das razões de ser fundamentais da geografia é a de tomar conhecimento da complexidade das configurações do espaço terrestre.” (LACOSTE, 2012, p. 66)

O método que permite pensar eficazmente, estrategicamente, a complexidade do espaço terrestre é fundamentado, em grande parte, sobre a observação das interseções dos múltiplos conjuntos espaciais que se podem formar e isolar pelo raciocínio e pela observação precisa de suas configurações cartográficas. (LACOSTE, 2012, p. 66-67) 
Conjuntos espaciais são as diversas instâncias da realidade sobre a qual se debruça cada especialidade científica, "representações abstratas, objetos de conhecimento e ferramentas de conhecimento produzidos pelas diversas disciplinas" (p. 67). São espaciais na medida em que se quer ressaltar o fundamental procedimento de análise do verdadeiro raciocínio geográfico que é o traçado dos limites de cada conjunto, na carta. E deve se ressaltar, ainda, a raridade em torno de dois conjuntos espaciais que coincidem em seus contornos, o que provavelmente expressa uma relação de causalidade.

A representação mais operacional e mais científica do espaço não é a de uma divisão simples em 'regiões', em compartimentos justapostos uns aos outros, mas a de uma superposição de vários quebra-cabeças bem diferencialmente recortados. (LACOSTE, 2012, p. 68)

Mas, ainda segundo Lacoste (2012, p. 69-70) seria necessário ir além, e raciocinar sobre as ordens de grandeza das diferentes espécies de conjuntos espaciais, que podem ser bem distintas. Não se trata, pois, de identificar a priori "realidades geográficas" evidentes ou coincidências de contornos de diversas categorias de conjuntos, que antes de serem regra, seriam exceção. Mas as representações tranquilizantes das regiões lablachianas, ideologicamente poderosas na constituição da ideia de pátria, ao naturalizar a repartição do espaço, pouco serviriam efetivamente para a ação, já que não refletiriam a realidade.

Não se pode perder de vista que a crítica de Yves Lacoste é direcionada à ciência geográfica praticada na França. Não se pode automaticamente direcioná-la às primeiras monografias regionais produzidas sob brigada da Faculdade de Filosofia da USP apenas pelo fato de estas serem tributárias diretas da tradição francesa de pesquisa e por guardarem similaridade com as dos mestres franceses. De todo modo, a proposta de divisão regional de Deffontaines, e também a de Monbeig, parecem, mesmo, orientar alguns dos primeiros trabalhos defendidos junto ao DG-USP. Apesar disso, em graus distintos, todas as teses consultadas parecem aproximar-se do fenômeno do dinamismo próprio da região Centro-Sul do país na primeira metade do século XX, em pleno processo de apropriação econômica, com grande instabilidade de estruturas e fluidez migratória. 


\subsubsection{Análise geral das teses consultadas}

Em termos formais, as teses de Silveira (1946), Santos (1951) e Ab'Sáber (1956) situam-se no âmbito da Geografia Física, as demais enquadrando-se no âmbito da Geografia Humana. Assim como atestado em relação aos materiais publicados pela RBG, contudo, em relação aos quais indicou-se a dificuldade de enquadramento de muitos destes a uma única subárea da ciência geográfica, também entre as teses de doutorado defendidas junto ao DG o enquadramento em termos de subárea de conhecimento reservam um elevado grau de arbitrariedade, frente ao conteúdo apresentado pelas mesmas.

Para a análise de aspectos gerais das primeiras teses de doutorado defendidas junto ao DG-USP, apoiamo-nos na profícua análise de Carlo Eugênio Nogueira (2015) já que, além de bem fundamentada e oferecer rara contribuição na análise da produção acadêmica do DGUSP em seu conjunto ${ }^{131}$, corrobora apontamentos e responde a dúvidas levantadas durante o fichamento dos materiais por nós consultados. Em seguida, procederemos com a exposição de aspectos selecionados das teses consultadas, ao longo da qual outros elementos podem ser observados. Segundo Nogueira (2015):

O sentido de grupo professado de um modo particular pelos geógrafos vinculados à FFCL/ USP (Andrade, 1987; Bernardes, 1982), perceptível nas escolhas temáticas, nos procedimentos de pesquisa e no arcabouço metodológico de predominante sotaque francês, permite que se enxergue ali a germinação de um conjunto de obras interligadas por certos denominadores comuns, tais como a predileção pelos conceitos de paisagem, região e habitat, a concepção da geografia como ciência de síntese que privilegia as relações homem-meio, a importância conferida ao trabalho de campo e as metáforas organicistas que estabelecem analogias entre os fenômenos físicos-naturais e as relações sociais, já que as últimas, esvaziadas de sentido crítico, seriam em grande medida condicionadas pelos primeiros. (NOGUEIRA, 2015, p. 3)

O autor busca demonstrar que ao tomar o fenômeno do pioneirismo um parâmetro de regionalização para o estado de São Paulo e, mais do que isso, parâmetro avaliativo para o processo de formação territorial do estado e do país, a equipe de pesquisadores formada em torno de Pierre Monbeig, através de uma linguagem comum, construiu um "indicador palpável para avaliar o nível de desenvolvimento dos lugares, visto que era então comum examinar o atraso ou o avanço das paisagens paulistas tendo-se como referencial a herança exercida pela ação ou pela ausência dos fatores que acompanhavam a atividade cafeeira." (NogueIRA, 2015, p. 4) Para os autores das teses de doutorado orientadas por Monbeig, os escritos do mestre seriam tomados:

${ }^{131}$ Não são raras as análises sobre a Geografia praticada pela primeira geração de geógrafos formada com a contribuição epistemológica francesa, porém, é praticamente unânime a análise em termos genéricos e abrangentes ou específica a um autor, objetivos diversos do nosso, nesse sentido. 
como o exemplo acabado do que deveria ser um trabalho científico em geografia, do qual a monografia regional descritivo-explicativa, apoiada em farto material cartográfico e iconográfico conseguido por meio das observações diretas efetuadas no campo, seria o epítome. (NoGUEIRA, 2015, p. 4)

A despeito do modelo monográfico tradicional de exposição das ideias e da abordagem evolutiva linear e naturalizante sobre o processo de formação territorial, elementos de fato identificáveis no conjunto das teses analisadas, a valorização dos fatores econômicos no processo de organização regional das paisagens

mostrava uma preocupação ímpar em desvendar as alterações que a consolidação de
uma nova estrutura social e econômica impunham às paisagens e populações tidas
como tradicionais, revelando de que maneira o desenvolvimento geograficamente
desigual do capitalismo (Harvey, 2004; Smith, 2008) brasileiro podia ser observado,
descrito e explicado pela geografia acadêmica recém institucionalizada, que
participava assim do debate mais amplo posto pelo pensamento político-social do
período (Brandão, 2007). (NOGUEIRA, 2015, p. 4)

Nesse sentido, é possível identificarmos nas teses compromisso com a realidade contemporânea à época em que foram escritas, embora os autores, em geral, assumam o olhar do Estado sobre o território e o discurso oficial desenvolvimentista. Além da apresentação geral de cada obra e de algumas passagens selecionadas dignas de destaque, outros elementos do pensamento de Monbeig presentes entre seus discípulos na análise do fenômeno do pioneirismo, identificados por Nogueira (2015), serão expostos ao longo das considerações relativas às teses consultadas.

\subsubsection{Uma crítica possível a partir dos clássicos}

Os autores apresentam - João Dias da Silveira é uma das exceções - reduzida preocupação com aspectos teórico-metodológicos. Via de regra, o objetivo dos trabalhos é a descrição de uma região tomada como objeto de estudo, a partir da análise de sua paisagem, cuja contribuição maior no plano intelectual, além do alargamento do conhecimento empírico das geografias do território nacional, é a reiteração de um modelo de pesquisa em Geografia. Embora em termos metodológicos os trabalhos sejam mais profícuos, o trabalho de Maria Conceição Vicente de Carvalho, por exemplo, é exemplar no emprego e demonstração de um modelo de pesquisas em Geografia, por meio de um conjunto de princípios e conceitos caros ao pensamento geográfico clássico, além do uso que faz da História na reconstituição das paisagens pretéritas, ao passo que diferentes atividades econômicas, com seus respectivos desdobramentos sobre os gêneros de vida, atuam no sentido de modernizar as paisagens ou 
levá-las à decadência, em uma perspectiva linear. $\mathrm{Na}$ aplicação desse modelo não há a preocupação de explicitação ou de justificação dos conceitos ou dos procedimentos adotados, relegando-se o debate epistemológico a um plano quase imperceptível. Deve-se relativizar, de todo modo, a afirmação da limitada contribuição metodológica entre as primeiras teses de doutorado defendidas junto à FFCL-USP, tendo em vista que, na época, a maior contribuição que se esperava era, justamente, realizar trabalhos segundo a perspectiva monográfica francesa.

Carvalho (1944, p. IV) observa que o avanço das técnicas e de grandes obras de engenharia alteram a dinâmica de ocupação e de povoamento de regiões antes inóspitas, podendo levar outras à decadência.

Em virtude disso é que nos estudos de geografia humana, que procuram, pela análise, explicar a paisagem atual e a maneira pela qual os homens se ajustaram a ela, há a necessidade de recorrer constantemente às outras ciências físicas e sociais.

A autora leva à risca o propósito atribuído à "geografia humana" e, segundo o modelo "natureza-população-economia", analisa diferentes facetas da paisagem que, no conjunto, reconstituem geografias em grande parte perdidas. Segundo Nogueira (2015), no geral, os primeiros geógrafos a defender tese junto ao DG-USP empreendiam uma tentativa de examinar as mudanças ocorridas em gêneros de vida historicamente arraigados a partir de uma série de procedimentos similares:

primeiramente, faziam a reconstrução temporal das relações sociais e das paisagens, como uma verdadeira monografia de geografia histórica clássica, uma vez que descreviam em minúcias a configuração territorial de seu espaço-objeto numa dada secção temporal, que ficava restrita aos períodos cobertos pelas raras fontes primárias que continham dados estatísticos. (NOGUEIRA, 2015, p. 8)

Do ponto de vista contemporâneo, a monografia de Maria Conceição V. de Carvalho assemelha-se a um trabalho histórico-geográfico a analisar - de forma uma tanto linear - as etapas históricas do desenvolvimento combinado de uma dada civilização com sua geografia, com suas variações regionais que redundam em diferentes paisagens e gêneros de vida e, dentro destas, nuances sub-regionais que resultam em variações nos modos de vida. A cada elemento considerado na descrição da paisagem - a distribuição da população, as diversas atividades econômicas, o desenvolvimento de diferentes habitações, o estabelecimento de caminhos - recorre-se à História para a explicação das feições presentes, mas a perspectiva geográfica repousa no compromisso com a análise da paisagem contemporânea e com a descrição do modo como grupo social e meio natural ajustaram-se mutuamente. ${ }^{132}$

\footnotetext{
${ }^{132}$ Cf. Moreira, 2008, em esp. p. 63-75, quando o autor analisa a obra Princípios de Geografia Humana, de Paul Vidal de La Blache, a partir do nexo discursivo formado pelas categorias de civilização e de gênero de vida, inspiradas no conceito de contingência.
} 
Compromissada com o presente, esta Geografia recorria à análise histórica para estabelecer em linhas gerais a dinâmica que teria resultado em uma determinada configuração espacial em épocas anteriores, sobre a qual o desenvolvimento de uma nova atividade econômica influenciaria a modernização ou a decadência dos gêneros de vida e a organização das paisagens do presente. (NOGUEIRA, 2015)

Descritiva, a geração de trabalhos inaugurada com Carvalho, ainda não tão afetada pela fragmentação acadêmica, parece oferecer um caminho epistemológico trilhado sobre uma referência teórica e metodológica comum. As poucas formulações explícitas nesse sentido não impedem que se identifique uma base de pensamento. Como tal pretensão se situa para além dos limites da presente dissertação, restringimo-nos a questionar os limites entre a descrição e a explicação.

Se a Geografia clássica é frequentemente acusada de descritiva e os geógrafos clássicos com frequência declaram, defensivamente, seu compromisso com a explicação, não seria o caso de se refletir sobre o que é descrever e o que é explicar, como se relacionam e o que as diferenciam ${ }^{133}$

À luz da necessidade de se levar em consideração determinados tipos humanos para se explicar paisagens regionais e, o contrário, os elementos constitutivos das geografias regionais para se explicar gêneros de vida correspondentes, esta primeira geração de pesquisadores universitários impressiona pela leitura integrada que faz do complexo geográfico e nos faz crer da impossibilidade de se compreender questões relativas ao ser humano desvinculado de seu meio geográfico.

\footnotetext{
133 "Além disso, admite-se facilmente que as operações mnemônicas não sejam as únicas atividades intelectuais capazes de orientar o geógrafo que estuda as relações dos complexos. A interpretação do encadeamento dos fatos depende do trabalho intelectual, no qual o encadeamento das idéias é primordial. Perceber-se-á isso acompanhando a análise do mecanismo intelectual na pesquisa geográfica tal como aparece num artigo do professor Henri Baulig.

"A primeira fase seria a da explicação. Faz-se mister tomar a palavra no seu sentido etimológico, isto é, desenvolver, desenrolar (explicare em latim designa a ação de desenrolar o rolo de pergaminho manuscrito). Depois de ter explicado, o geógrafo deve compreender. Isto é, deve reunir todos os fatos por ele desenrolados, procurando tomá-los em conjunto, como uma unidade. Se, a esta interpretação humanista do método de pensamento do geógrafo, preferir-se outra, poder-se-ia dizer que o geógrafo se encontra em face dum complexo geográfico, como um mecânico diante de um motor desconhecido cuja disposição quisesse conhecer. É necessário desmontar as peças que compõem o motor, tendo, porém o cuidado de identificar cada elemento, de ver como se ajusta a outro, de conhecer-lhe a função e avaliar-lhe a importância do conjunto. Este trabalho de desmontagem do motor é a explicação do complexo geográfico. Depois de identificadas todas as peças, numeradas, classificadas, nosso mecânico se encontra melhor preparado para conhecer de que modo a união delas constitui um motor e como funciona este. Ele 'compreende' porque pode, segundo a análise, aprender as relações dos diferentes elementos entre si e graças a esse primeiro trabalho, descobrir como cada um contribui para a boa marcha do conjunto." (MonBEIG, 1957, p. 14) O que Monbeig chama de "explicação", chamaríamos de "análise" ou, mesmo, "descrição".
} 
Ainda que se postule a insuficiência do método geográfico regional clássico quando tomamos em consideração as intrincadas questões políticas e culturais do mundo contemporâneo, sobejamente atreladas às complexas e multi-escalares geografias urbanas, com suas componentes relativas ao capitalismo global e financeiro, parece-nos que uma parte não descurável das tensões, medos e angústias típicas de nosso tempo não pode ser explicada sem a notável habilidade presente entre os clássicos de se conceber a unidade do homem com seu meio.

Diante desta reflexão, ao invés de se declarar a impossibilidade de uma aproximação metodológica entre os universos de pesquisa da Geografia Física e da Geografia Humana, uma crítica mais radical aparenta ser necessária, em bases mais profundas. A crítica ao pensamento geográfico não pode desvincular-se do debate relativo ao próprio pensamento científico e suas bases filosóficas e metodológicas. Não se trata de versar sobre a interdisciplinaridade, mas de se refletir sobre a própria disciplinaridade, a linearidade do discurso e a possibilidade de um método de pesquisa para uma ciência histórica mais abrangente. Embora, reitera-se, reconheçamos a escala de tal empreitada, restringimo-nos a afirmar que Geografia tradicional pode ser indicativo de uma crítica possível ao pensamento científico moderno, de forma geral, e ao pensamento geográfico, de forma específica. ${ }^{134}$

\subsubsection{Eleição da região-objeto e determinismo geográfico}

As primeiras teses de Geografia defendidas junto ao Departamento de Geografia da então FFCL-USP orientam-se segundo um recorte regional, metodologicamente estruturado segundo a tradição monográfica francesa. Com exceção de Renato da Silveira Mendes (1948), cujo objeto é uma região no estado do Rio de Janeiro, as demais teses versam sobre um recorte regional do território paulista. ${ }^{135} \mathrm{Na}$ eleição de uma região-objeto, nota-se a

\footnotetext{
${ }^{134}$ Pela complexidade, extensão e ainda bastante vaga reflexão, evitamos propor qualquer formulação concreta. Um debate entre filosofia e história da ciência e Geografia parece realmente necessário e possível. Um conjunto de leituras paralelas ao objeto principal da pesquisa fomentaram a presente reflexão, que infelizmente não redundou em nada efetivo. Os autores lidos foram: ARENDT, H. Entre o passado e o futuro. 7.ed., São Paulo: Perspectiva, 2010; Boudon, R. Métodos da sociologia. 2.ed., Petrópolis: Vozes, 1971; Chalmers, A. O que é ciência, afinal? São Paulo: Brasiliense, 2010; Giddens, A.; TURNER, J. (Orgs.). Teoria social hoje. São Paulo: Ed. UnESP, 1999; LöwY, M. As aventuras de Karl Marx contra o Barão de Münchhausen. São Paulo: Cortez, 2009; WeBER, M. Ensaios de sociologia. 5.ed., Rio de Janeiro: Guanabara Koogan, 1982.

135 Já afirmamos, com base principalmente em Seabra (2004), a perspectiva de engajamento da Geografia acadêmica paulista ao projeto imperialista de desenvolvimento econômico do estado de São Paulo, que reflete o próprio projeto de criação da Universidade de São Paulo e está refletida na escolha das regiões objetos de estudos.
} 
preocupação de identificação de uma área cujos aspectos intrínsecos a singularize em relação às demais. Não há preocupação pela explicitação dessa escolha metodológica, mas João Dias da Silveira, de maneira isolada e surpreendente, expõe a natureza subjetiva da escolha da região de estudo. Convém, assim, destacar os critérios de delimitação da área eleita para o estudo regional, segundo Silveira:

$\mathrm{Na}$ verdade, qualquer região se presta a um estudo geográfico. O estudioso familiarizado com a pesquisa sente exatamente isso, pois que, em toda parte a interrelação dos fenômenos e problemas cria situações interessantes e dignas de serem estudadas para que se estabeleçam interpretações e conclusões. A escolha desta ou daquela paisagem para uma monografia, principalmente, para trabalhos deste gênero, prende-se sobremodo, a fatores subjetivos. Objetivamente funciona a facilidade de limitação que, todavia, só pode ser integralmente considerada em áreas bastante estudadas. Entre nós, a determinação de limites regionais precisos exigem ainda muitas monografias e trabalhos de sínteses. A delimitação de paisagem requer mais do que esboços, que isoladamente podem ser traçados pelo pesquisador regional. Só a aplicação de trabalhos de comparação poderá trazer resultados apreciáveis, isso porém, só se torna possível depois de muitas monografias e conclusões. (SILVEIRA, 1948, p. 4-5, grifos nossos.)

Silveira faz uma rara explicitação do caráter subjetivo de suas escolhas e da ausência de critérios objetivos na delimitação de uma área de estudo, principalmente quando os estudos relativos a uma área ainda são pouco numerosos, situação comum no Brasil. A este respeito, Richard Hartshorne, ao discutir uma possível acepção técnica mais precisa ao termo "região", parece traduzir o que apenas Silveira expôs entre as teses consultadas. Segundo Hartshorne, uma "divisão realista em regiões, não importando qual seja a definição da palavra região, obriga o pesquisador a tomar decisões subjetivas ao pesar a importância dos diferentes fenômenos.” (HARTSHORNE, 1978, p. 139) Isto porque os aspectos mais significantes que definiriam um dado tipo de região não podem ser deduzidos a priori, para além daquelas combinações de fenômenos muito elementares. O conceito de região e o método regional são aplicáveis desde a análise das integrações mais elementares, no plano do estudo tópico, até o estudo de regiões que contemplam o maior número possível de elementos em integração, no plano do estudo regional, sem que seja possível, de maneira relevante, definir-se em nenhum momento critérios gerais de delimitação de regiões com certo grau de homogeneização.

José Ribeiro de Araújo Filho (1950), por exemplo, fornece, como parte de suas justificativas para a escolha da região de estudo, o fato de o pai e o tio terem sido os responsáveis por iniciar o plantio de banana na região. Teria chamado sua atenção, na época (1927), "encontrar uma paisagem tão pouco trabalhada pelo homem”. (ARAÚJO FILHO, 1950, p. I) Além disso, a quase ausência de estudos para a região seria outro motivo para estudá-la.

O pioneiro trabalho de Maria Conceição Vicente de Carvalho (1944) busca indicar como sua área de estudo se singulariza por sua posição, entre duas zonas geomorfológicas 
distintas e ponto de convergência de atividades econômicas tanto do litoral quanto do interior. Elina de Oliveira Santos (1951), igualmente, busca nos próprios elementos do meio, justificar a relevância de sua área de estudo:

A originalidade geográfica do quadro natural da região de Sorocaba decorre de sua posição numa zona de contato geológico e morfológico. Trata-se de uma área onde dois domínios de formas de terrenos, solos, clima e vegetação criaram contrastes nas paisagens e diferenças nas atividades econômicas. (SANTOS, 1999, p. 21)

Pautados por esta perspectiva regional, o paradigma da relação sociedade-natureza dava a tônica da essência das preocupações geográficas do período. Tal paradigma expressava-se, explícita ou implicitamente, através da perspectiva do possibilismo geográfico e, não-raro, o geográfico da realidade era subentendido como as condições naturais sob as quais os grupos humanos são submetidos ou submetem, através das técnicas, ao seu desejo. Não há, vale assinalar, monografia que verse sobre uma geografia regional na qual o elemento humano não seja relevante a ponto de não dever ser a preocupação central da análise; tampouco há exemplo de estudo regional que destaque uma situação de triunfo das condições do meio sobre o homem. O determinismo geográfico, não como um constructo teórico-metodológico tal como entendido na atualidade, mas como fato a ser medido na realidade, aparece sempre como uma condição gradativa e transitória, o ambiente opondo-se até certo ponto ao progresso das civilizações e suas técnicas.

Assim, além da descrição da paisagem sui generis de Santos no litoral paulista, o objetivo de Carvalho (1944) é indicar a maneira pela qual as atividades humanas se fixam e florescem em uma zona historicamente de passagem, tendo-se em vista o relevo, o clima e o meio biológico hostis ao homem, "reduzindo-lhe a capacidade de trabalho". O litoral paulista

Seria um exemplo frisante da teoria de Ratzel e da escola dos geógrafos alemães,
demonstrando a influência predominante do meio físico sobre as atividades
humanas, se não houvesse uma exceção, que é o caso de Santos. Não se tendo
destacado dos outros núcleos de povoamento durante os três primeiros séculos, a
construção da estrada de ferro partindo de Santos para atingir o planalto, veio
transformar a fisionomia de toda a região litorânea. (CARVALHO, 1944, p.VI)

Entre os geógrafos pioneiros do DG-USP, a contribuição em termos de teóricos para o pensamento geográfico, salvo contribuições conceituais para subáreas específicas da ciência geográfica, parece restringir-se ao debate relativo ao determinismo geográfico. Assim mesmo, não se trata de problematizar os fundamentos teóricos da questão mas, por meio da análise histórica da paisagem dedicar-se, nos estudos de caso, à demonstração das possibilidades de desenvolvimento do artifício humano ante às imposições do meio. Maria da Conceição V. de Carvalho, ao descrever as condições naturais do Porto de Santos, principia com uma descrição 
em termos hidrográficos, de profundidades dos canais e do problema do atulhamento por sedimentos fluviais. "Depois de lutar contra as águas para criar um porto e uma cidade moderna, os homens vêm-se obrigados a lutar contra as aluviões para salvar sua obra." (CARVAlHO, 1944, p. 148)

Como pontos desfavoráveis ao estabelecimento do Porto, a autora elenca o clima úmido e quente e o desenvolvimento de grandes focos de mosquitos, transmissores de moléstias. Outro ponto negativo seria a muralha de montanhas, isolando Santos, reduzindo-lhe a área circundante e a conexão com outras áreas. "Entretanto, o determinismo do meio geográfico atuou somente até um dado momento. De certo ponto em diante os homens conseguiram sobrepor-se a eles, fazendo prevalecer os fatores favoráveis, que lhes podiam ser úteis." (CARVAlHO, 1944, p. 149, grifo nosso.)

A autora descreverá como ocorreu essa mudança de aproveitamento das potencialidades do meio. De imediato, o colonizador voltou-se para o interior, desprezando as qualidades santistas. Enquanto a economia era centralizada na cana e no ouro, pouco pôde oferecer Santos. Foi o café e as novas técnicas de comunicação que permitiram aproveitar as vantagens naturais da localização do porto.

Fica demonstrado mais uma vez que, se é indiscutível a influência do meio natural, essa influência só pode atuar sob determinadas condições; modificadas estas, o determinismo perde a força. O fator humano, representado pela estrada de ferro e pela nova cultura cafeeira foi a causa essencial do aproveitamento das condições naturais. (CARVALHO, 1944, p. 150. Grifo nosso.)

Trata-se de uma característica comum aos trabalhos analisados as contribuições teóricas limitadas, frente ao papel desempenhado pela descrição. Em geral, objetiva-se aplicar o chamado "método regional", de modo a se contribuir com o conhecimento indutivo do "solo brasileiro". Para além do valor explicativo que uma descrição tão rica na construção de imagens, como a de Carvalho, pode ter, a maior contribuição teórica que a autora proporciona reside, mesmo, na demonstração empírica de certos limites do determinismo geográfico sobre o destino das atividades humanas.

A reduzida preocupação teórica e metodológica da "jovem e ativa escola paulista de Geografia" (PAPY, 1957, p. 141), contudo, contrasta com a grande importância que estes trabalhos teriam para a primeira geração de geógrafos que começava a se formar nas Universidades de São Paulo e do Rio de Janeiro, já que praticamente não havia, ainda, trabalhos anteriores para subsidiar revisões bibliográficas. Dentro de cada subárea da Geografia, portanto, o desenvolvimento conceitual específico encontrava nestes trabalhos seminais e desbravadores, praticamente, as primeiras referências em língua portuguesa, dentro 
de um arsenal metodológico declaradamente alinhado com os preceitos da então Geografia Moderna. Igualmente no plano metodológico, estes primeiros trabalhos forneceriam um modelo de estrutura e de linguagem para toda a Geografia brasileira. Não por acaso, Louis Papy $(1957)^{136}$, ao produzir um trabalho regional-descritivo - exemplar quanto ao modelo de pesquisa - relativo ao litoral paulista, agradece a praticamente todos os membros da comunidade de geógrafos atrelada ao DG-USP, indicando a formação de uma comunidade intelectual referencial básica.

Nossa leitura encontra respaldo também na avaliação de Manoel Seabra com relação ao papel desempenhado pelos mestres franceses envolvidos na fundação não apenas do curso de Geografia e História da USP, mas também da AGB-SP:

Não cabe aqui [pesquisa do autor] a crítica da concepção de região então dominante na Geografia e não apenas na "francesa" e nem o uso da monografia regional como "método" de investigação. Mas cabe lembrar que parte significativa das teses defendidas no Departamento de Geografia, sem entrar no mérito de suas qualidades diferenciadas, tiveram esta característica, pelo menos até os anos 1960. Por outro lado, não é possível que isto tenha sido uma consequência imediata apenas da presença de Deffontaines. Monbeig, seu sucessor, que aqui ficou por onze anos, também valorizou - não apenas - significativamente este tipo de investigação e, Geografia, ainda que sua tese principal [Pionniers et Planteurs de São Paulo], defendida na França no fim dos anos 1940, não se enquadre bem na ideia de "monografia regional clássica".

O "paradigma" central desta Geografia continuava a ser a relação sociedade/natureza. [...] A outra contribuição de método que Deffontaines trouxe diz respeito à ênfase que dava ao trabalho de campo, strictu sensu, em Geografia e da excursão como atividade pedagógica relevante de seu ensino. (SEABRA, 2004, p. 28/29. Grifo do autor.)

$\mathrm{Na}$ leitura de Seabra, tanto o modelo monográfico regional, quanto o discurso centrado na relação sociedade-natureza, bem como a adoção do método historicista (possibilista) e da prática do trabalho de campo não são exclusivos de Deffontaines, sendo adotados também por Monbeig, cuja grande influência intelectual sobre a primeira geração de pesquisadores oriundos do DG-USP já foi apontada.

\footnotetext{
${ }^{136}$ PAPY, Louis. À margem do império do café. A Fachada Atlântica de São Paulo. Boletim Geográfico, v. 15, n. 137, 1957, p. 139-166. (Transcrições.) Na versão on-line disponibilizada pela Biblioteca do IBGE, não constam as páginas 164 a 166.

Trabalhos como esse ou, de forma ainda mais privilegiada - já que valorizaria a história do DG-USP -, as primeiras teses defendidas junto ao DG, poderiam ser utilizadas pelos professores deste Departamento como exemplares de monografias obedientes ao modelo regional descritivo. São numerosas as críticas a esse modelo e mais numerosas, ainda, as dúvidas, junto aos alunos, quanto à natureza de trabalhos idiográficos ou regionais da chamada Geografia Tradicional.
} 


\subsubsection{A explicitação de um modelo, segundo Silveira (1948)}

O trabalho de João Dias da Silveira foge à regra e reserva alguns preciosos parágrafos a considerações de ordem metodológica, além de procurar justificar em termos teóricometodológicos seu objeto de estudo. Embora o trabalho de Nice Lecocq Müller (1946) ofereça uma contribuição muito duradoura em termos explicitamente conceituais, que o destaca frente aos demais, de qualquer forma trabalhando um conceito antropológico não específico à Geografia - o caipira - e as paisagens a ele relacionadas, é Silveira (1948) quem disserta sobre a importância de seu objeto de estudo em termos teóricos para o edifício geográfico. As páginas introdutórias de seu trabalho, ao longo das quais justifica o modelo de pesquisa e o recorte regional adotados, são fascinantes quanto à consciência de suas escolhas no plano intelectual. Tomamo-las como exemplares do pensamento geográfico de uma época, já que o autor explicita princípios geográficos da Geografia tradicional presentes em trabalhos como o de Carvalho (1944), por exemplo, embora incorramos ao risco de generalizar preocupações teóricas eventualmente ausentes em outros autores do período.

João Dias da Silveira, o primeiro a ocupar a cátedra de Geografia Física do DG-USP, criada em 1939, justifica a escolha por um "estudo monográfico" por ser "o mais condizente com a função da Geografia" (grifo nosso), além de melhor revelar suas qualidades de pesquisador. O pleno domínio do método e do objetivo da Geografia, evidenciável em estudos monográficos, exigiria comprometimento com o todo, isto é, a paisagem. As subáreas desta ciência, quase sempre arbitrárias, cumprem apenas as demandas didáticas e de carreira.

Para ser geográfica e atender às finalidades da ciência ela deve ser integral, isto é, procurar esclarecer todas as relações existentes entre os fenômenos. Em pesquisa geográfica pura, não convem limite a este ou aquele aspecto. O objetivo deve ser o todo, isto é, a paisagem, esse conjunto que reúne todos os fatores, sem ser, porém, a soma deles. (SILVEIRA, 1948, p. 2, grifo do autor.)

A definição de uma paisagem, em um estudo monográfico, "exige a observação de inúmeros aspectos e dados", mas deve ganhar em utilidade e complexidade com a "meditação" e "interpretação" quanto ao "estabelecimento de relações". A este respeito, o autor insiste no que chama de "preocupação geográfica".

As interpretações integrais das diferentes paisagens constituem mesmo o verdadeiro objetivo da ciência a que nos vimos dedicando. São necessários ao trabalho geográfico a localização, a extensão, as conexões, bem como comparações. Ora, é no estudo das paisagens que se podem precisar as áreas de ocorrência dos fenômenos; aí é que se entrosam e através de correlações surgem as diferentes combinações. O conhecimento desses fatos, isto é, de relações e limitações das zonas de combinações forma a razão de ser da Geografia. As comparações com outras regiões, o que somente é cabível, cientificamente, depois de terminados os 
estudos monográficos, completam os trabalhos, quando se visa o estabelecimento de princípios gerais. Esta última fase, todavia, é mais de gabinete que de campo, mais de meditação que de pesquisa pura. (SILVEIRA, 1948, p. 2-3)

A "preocupação geográfica" explicita um princípio metodológico fundamental dos estudos monográficos tradicionais, na medida em que dá sentido à descrição dos conteúdos observados em campo, mediante o estabelecimento de relações entre os fenômenos. Não se pode desconsiderar a importância da análise dos diversos elementos que compõem uma paisagem, já que constituem o próprio objeto de estudo, mas o objetivo da ciência geográfica se revela plenamente através da interpretação da relação que se estabelece entre os fenômenos que compõem o todo, a paisagem. Aspectos em detalhe "devem ser analisados para que as paisagens possam ser interpretadas, mas elas, em seu conjunto, é que constituem a verdadeira meta que visamos." (SILVEIRA, 1948, p. 3) O autor expõe que cogitou a possibilidade de estudo de uma região natural:

O contato com a paisagem nos mostrou a dificuldade desse proceder e as vantagens de um trabalho global. A região que consideramos foi desde muito povoada e explorada por um homem empírico em suas atividades e que vem atuando como precioso fator de evolução dos elementos naturais. (SILVEIRA, 1948, p. 4)

Em suas considerações relativas ao método de pesquisa, embora as relações homemmeio estejam sempre em debate, Silveira coloca a região no centro da análise e não parece dar atenção maior às atividades humanas do que daria a fenômenos naturais na alteração da paisagem regional considerada. O peso aparentemente igualado dos fatores em relação contrasta, todavia, com uma preocupação antropocêntrica observada no restante do texto, ao longo do qual considera-se o desenvolvimento histórico da paisagem e o papel das atividades humanas ao longo de diferentes ciclos econômicos.

Embora as monografias analisadas possam parecer enfadonhas e de reduzido alcance crítico a longo prazo, mesmo que se considere as preocupações metodológicas pontualmente expostas pelos autores, ao menos a importância dada à relação entre os fenômenos é um aspecto metodológico que, frente à acusação de enciclopédicas, parece distanciá-las de uma outra Geografia, não analisada por nós na presente pesquisa. Vale ressaltar que Yves Lacoste (2012) tem como centro privilegiado de suas críticas a Geografia acadêmica francesa. Nos materiais analisados por nós a ciência geográfica parece dar sentido aos diversos elementos em interação na medida em que se compromete com as relações estabelecidas entre estes elementos, mais do que com os elementos em si: 
Eis mais uma razão a obrigar-nos a fugir de um assunto de detalhe. Eles devem ser analisados para que as paisagens possam ser interpretadas, mas elas, em seu conjunto, é que constituem a verdadeira meta que visamos. O estudo das formas do terreno só é feita pelo geógrafo para atender a um aspecto da região. Estudandoas como preocupação final, fugiríamos ao objetivo geográfico para cuidarmos unicamente de geomorfologia. É necessário, pensamos, muito cuidado para que o trabalho geográfico nem se exceda, nem se desvirtue. (SILVEIRA, 1948, p. 3) ) $^{137}$

Deve-se refletir, pois, em que medida o geógrafo deve se aprofundar na análise dos fenômenos que interagem na formação de uma dada geografia regional, em função do problema maior da natureza da relação estabelecida entre estes fenômenos. Ainda que tal questionamento não livre a ciência geográfica de dificuldades relativas ao método, a meditação sugerida por Silveira poderia impedir os geógrafos da especialização extrema ou dos tradicionais debates relativos aos limites da ordem disciplinar.

Ainda em relação às passagens destacadas de autoria de João Dias da Silveira, não obstante as preocupações com outro princípio metodológico caro à Geografia tradicional, a da relação pendular entre a Geografia Regional e a chamada Geografia Geral ou Sistemática, expostas nas páginas metodológicas iniciais de seu trabalho, o catedrático desenvolve sua pesquisa seguindo uma estrutura muito semelhante à apresentada por outros candidatos à obtenção do título de Doutor. O fato é que as primeiras teses defendidas junto ao DG-USP apresentam, em geral, a estrutura "natureza-população-economia" e, se os estudos monográficos devem preparar a pesquisa para ulteriores comparações visando o estabelecimento de princípios gerais, esta preocupação não é facilmente apreensível nestes trabalhos.

Seja como for, de maneira idêntica ao que ocorria na maior parte dos trabalhos inspirados no modelo regional cunhado por Albert Demangeon e Raoul Blanchard, também nas teses de doutoramento dos geógrafos brasileiros a ordem de exposição dos assuntos seguia a sequência básica quadro natural, história, homens e atividades, generalizada para praticamente toda a produção geográfica brasileira acerca do mundo agrário nas décadas de 1940 e 1950, período definido como os anos dourados da geografia agrária brasileira (Ferreira, 2002). (NogUEIRA, 2015, p. 7)

\footnotetext{
${ }^{137}$ Devemos, contudo, considerar as tradicionais dificuldades relativas ao método. Na descrição geral de sua área de estudo, o autor destaca a carência de dados geológicos, climatológicos, biogeográficos, bem como recenseamentos demográficos e econômicos completos para a região, o que a tornaria atrativa e com elevado potencial educativo justamente por conta disso.

$\mathrm{O}$ autor calcula a área em aproximadamente $8.000 \mathrm{~km}^{2}$ e reitera não se tratar "de região completamente delimitada. Ao norte e a leste, ainda que ocorram modificações de ordem econômica e social, persistem aspectos físicos." (SILVEIRA, 1948, p. 9) A questão de correlacionar fatores díspares e, dessa correlação, extrair uma correlação específica que delimite uma região e a torne singular, encaminha, mesmo, o trabalho para uma análise quantitativa à semelhança do que parece sugerir Hartshorne (1978).
} 


\subsubsection{O pioneirismo de Carvalho (1944) e a posição estratégica de Santos}

A defesa da tese de doutorado de Maria Conceição Vicente de Carvalho, Santos e a geografia humana do litoral paulista, em 1944, pode ser considerada um marco da Geografia brasileira. Química industrial "pelo Mackenzie College, professora secundária de Geografia, entrou como aluna ouvinte ${ }^{138}$ [do curso de Geografia e História do DG-USP] e, em 1936, tornou-se aluna regular; futura professora, pelo menos por um período da década de 1940, do Departamento de Geografia" (SEABRA, 2004, p. 16), Carvalho tornou-se a sexta pesquisadora a defender tese na FFCL-USP ${ }^{139}$, segundo o Anuário da FFCL-USP, 1939-1949, e a primeira no âmbito da Geografia no Brasil, segundo Andrade (1994) ${ }^{140}{ }^{141}$. Para se ter uma ideia da precedência deste evento, basta assinalar que a primeira dissertação de mestrado defendida junto ao Departamento de Geografia da UFRJ data de 1975, enquanto o doutorado surgiria apenas 20 anos depois. ${ }^{142}$

A pós-graduação em Geografia da UFRJ se torna um núcleo difusor da Geografia no Brasil, dividindo esse papel durante um bom período principalmente com a Universidade de São Paulo, muito embora seu doutoramento só tenha tido início nos anos 1990, a mesma década em que os programas de pós-graduação começam a proliferar em todo o país. (MACHADO, 2009, p. 174)

Após breve preâmbulo teórico, Carvalho (1944, p. IV) se debruça sobre o litoral de São Paulo, "zona de povoamento antigo que, no entanto, apresenta hoje pequenas densidades de população.”

Dividida em três capítulos, a primeira parte de sua obra ("Parte 1. Os elementos do meio") é dedicada à caracterização geral do litoral paulista, em termos naturais e humanos. Em termos naturais, o primeiro item trata de uma descrição geomorfológica do litoral paulista,

\footnotetext{
138 O Decreto n. 6.283, de 25 de jan. 1934, que criou a USP, previa a possibilidade de especializações através da realização, não de curso completo, mas de disciplinas específicas. Talvez fosse este o caso de Maria Conceição Vicente de Carvalho. Cf. Art. 11, Parágrafo Único, do referido decreto.

${ }^{139}$ As primeiras cinco defesas de doutorado da Faculdade foram todas de História, sendo a primeira de autoria de Eurípedes Simões de Paula, em 1942, segundo o Anuário da FFCL-USP, 1939-1949 disponível da biblioteca do Instituto de Matemática e Estatística da USP.

140 Devido à enorme importância histórica que atribuímos à tese de Carvalho, inclusive para uma maior valorização da história do Departamento de Geografia da USP, tentamos rastrear alguma eventual tese defendida antes de 1944 no Brasil, sem sucesso.

${ }^{141}$ Segundo relato de Ary França, Carvalho era assistente permanente de Pierre Monbeig e se entendia muito bem com ele. "Mas a Conceição foi sendo alijada aos poucos, por que não queria fazer o doutoramento. Ela resistiu muito, estava sendo obrigada a fazer. Acabou fazendo no final, mas muito aborrecida e meio corrompida com o Monbeig." (FRANÇA, 2005, p. 48)

${ }^{142}$ Frente à enorme relevância em si mesma deste trabalho, é triste a constatação de termos encontrado apenas uma fotocópia, já antiga e de leitura bastante difícil, da versão original. Também não encontramos nenhuma republicação da obra, indicando que não houve interesse de nenhum núcleo de pesquisa ou de preservação da memória pela reedição da mesma.
} 
a partir da identificação de duas porções de litoral, dispostas à sudoeste e à nordeste de Santos. No final da redação, a autora trata especificamente da topografia santista.

$\mathrm{Na}$ zona de contato, Santos participa de ambas as regiões, conservando, ao mesmo tempo, caracteres que lhe são próprios. [...] Por ser uma zona de contato entre duas regiões diferentes, pela maior acessibilidade tanto do lado do mar, como do interior do continente, esta região se tornou o ponto de convergência da maior parte das atividades do litoral, o verdadeiro centro de toda a região marítima paulista." (CARVAlHO, 1944, p. 11)

O segundo item de sua descrição dos elementos naturais é dedicado ao clima, solo e vegetação. Digno de nota é o acento antropocêntrico dado à descrição, ou seja, a descrição se dá muito em função do aproveitamento humano. "Estando voltado para o mar, sua fonte de subsistência, o homem do litoral ainda não encontrou o equilíbrio com o meio vegetal que o cerca." (CARVALHO, 1994, p. 20)

A autora prossegue, então, com a descrição da hidrografia e da dinâmica de sedimentação nos canais relacionados ao Porto e, de maneira objetiva, faz considerações sobre a mudança na hidrografia e no regime de sedimentação decorrentes da interferência humana. Faz considerações, ainda, sobre o relevo marinho e as marés.

Quanto aos fatores humanos, a autora principia com uma descrição bastante breve do povoamento do litoral paulista, de período anterior à colonização à meados do século XIX. Em seguida, descreve evolução das densidades populacionais nos litorais Norte e Sul, em Santos e no Planalto, em função do desenvolvimento das diferentes atividades econômicas. “Assim, nota-se desde logo, o predomínio da zona central, ponto de contato entre as duas, como região natural, mas que se diferencia de ambas, sob o ponto de vista demográfico." (CARVAlHo, 1944, p. 45) Por fim, dedica-se à formação étnica das populações. "A região litorânea, por onde tem penetrado o grande contingente imigratório, é para o imigrante do século XX, o que fora para o português do século XVI: uma zona de passagem." (CARVALHO, 1944, p. 53)

A segunda parte do texto de Maria Conceição Carvalho ("Parte 2. Os gêneros de vida do litoral") dedica-se à descrição dos tipos humanos que habitam o litoral paulista, atentando-se às nuances sub-regionais em termos habitacionais, culturais e econômicos.

No item inicial dedicado aos padrões de povoamento, a autora localiza e distribui, tipologicamente, as aglomerações humanas, seja em função do melhor aproveitamento dos elementos naturais, seja em função de fatores históricos que retrocedem à época da colonização.

O povoamento pode ser estudado sob dois aspectos diferentes: considerandose a localização dos grupos de habitações humanas na região, de acordo com a 
forma, a origem e a função que exercem esses grupos, e tomando com objeto de estudo a casa em si, que, como a classificou Brunhes é por excelência, um fenômeno geográfico, que interfere em todos os estudos de geografia humana. Tal como o povoamento, a casa obedece a influência do meio físico quanto ao material, à orientação, aos fatores históricos e à função que exerce no gênero de vida dos habitantes. Tanto na cidade, como no campo, ela está sujeita a variações no tempo e no espaço. (CARVALHO, 1944, p. 56)

A autora incialmente descreve, indicando um princípio classificatório, quatro formas de distribuição das casas, com base no observado em sua área de estudo: "nas praias curtas", "nas praias longas", "ao longo de caminhos" e "nas costeiras mais íngremes". Em seguida, discorre (p. 57-70) acerca dos fatores que contribuem para a localização das habitações, em função do meio geográfico: "acesso à água doce", "abrigo contra os ventos do mar", "facilidade de circulação"143 e "topografia"; e em função de fatores não-relativos ao meio geográfico: "herança cultural" e "gênero de vida rural", que Damangeon prefere denominar "economia agrícola".

Em seguida, a autora disserta sobre os diferentes tipos de habitação (p. 71-99), em função dos tipos humanos e das atividades econômicas a eles relacionadas.

Tão expressivo quanto a maneira de se localizar no solo, é o estudo das habitações humanas. A casa, disse Brunhes, por sua fixidez, é um elemento característico da paisagem geográfica. Representa uma adaptação às condições do meio, no material usado na sua construção ou na orientação da fachada, mas também se acha ligada às outras atividades dos seus habitantes, o que se evidencia mais na casa rural do que nas habitações urbanas. [...]

Sujeitas a influências tão diversas, as casas podem variar ao infinito e, mesmo quando se trata de povoamento antigo, estagnado, numa região onde existe bastante uniformidade quanto à origem dos habitantes, à maneira de acomodar-se às condições naturais e ao gênero de vida, as casas tomam aspectos bem diversos, conforme o material encontrado mais à mão, pau a pique ou pedra, o grau de civilização do construto, a função que vai desempenhar na vida deste. (CARVALHO, 1944, p. 71/72)

A casa obedece também à influência da civilização, que leva consigo costumes herdados, muitas vezes estranhos à região de destino. Mas ocorrem também as adaptações entre a cultura herdada, a influência cultural local e as condições disponíveis no meio. Apesar disso, segundo a autora, frente à soluções idênticas para problemas similares, é possível estabelecer-se tipos característicos, com base nas semelhanças, mais numerosas que as diferenças. "Das casas rurais mais expressivas existentes na orla marítima, podem-se distinguir três tipos que correspondem a três gêneros de vida e a três níveis de vida diversos." (CARVAlho, 1944, p. 77) São elas a "casa grande dos engenhos antigos", a "casa do pequeno sitiante" e a "casa do pescador". A autora segue, com grande acuidade, descrevendo áreas,

\footnotetext{
${ }^{143}$ As poucas referências bibliográficas, em geral, são a Friedrich Ratzel ou a geógrafos franceses, como Jean
} Brunhes: "O caminho é essencial, mesmo para uma população ensimesmada como essa." (CARVALHO, 1944, p. 60) 
ruínas ou arquiteturas ainda conservadas, remanescentes de épocas passadas, testemunhos de uma geografia em grande parte perdida. Por fim, com um acento intensamente histórico, a autora disserta sobre os tipos de casa urbana, que representam papel menos ativo do gênero de vida e deixam de ser o cenário das atividades do seu morador. Tais casas refletem menos a influência do meio do que da cultura, ainda mais num país como o Brasil, ainda tão influenciado pelas culturas estrangeiras. No litoral, adormecido durante três séculos, "a casa tem conservado em geral o padrão primitivo, introduzido pelo português." (CARVALHO, 1944, p. 91)

Nos três itens seguintes da Parte 2 de seu trabalho, Maria Conceição Carvalho disserta sobre os três gêneros de vida do litoral, o do pescador, o do agricultor e o do citadino.

Dos gêneros de vida do litoral, o que primeiro vai ser estudado é o do pescador, tanto porque é o mais ligado ao meio local, como por melhor caracterizar-se, livre como ainda se acha de quase toda influência recente da civilização. (CARVALHO, 1944, p. 100)

De maneira geral, a autora descreve paisagens, desenvolvimento histórico de diferentes atividades econômicas, além de técnicas de trabalho e níveis de vida de cada tipo humano abordado. Ao dissertar sobre o gênero de vida do pescador, por exemplo, a autora dedica aproximadamente seis páginas descrevendo, quadro a quadro, a técnica de construção de canoas e os aparelhos e sistemas empregados na pesca, especialmente a tradicional e a de tainha. Assim como observável em outros autores, Carvalho faz considerações de ordem econômica, ainda que pontuais:

Entretanto, embora sejam muitos os processos de pescar nas praias e nos canais,
todos eles são bastante primitivos, limitando-se a recolher o peixe que na verdade
vem involuntariamente oferecer-se para o sacrifício. Sem aparelhamento, sem
transporte, sem recursos, ignorante, o pescador não pode ter na pesca senão uma
base econômica incerta, caprichosa, de rendimento medíocre, para não dizer nulo.
(CARVALHO, 1944, p. 112)

Ao abordar o gênero de vida agrícola, Carvalho dedica algumas páginas à cultura da banana, que receberá um tratamento monográfico específico por José Ribeiro de Araújo Filho (1950) sobre a região produtora de Itanhaém. "Hoje a região litorânea produz 43,49\% do total do Estado, atraiu uma nova imigração, de nacionais e de japoneses e, fora o porto de Santos, constitui a maior riqueza da zona costeira." (CARVALHO, 1944, p. 119) O fruto foi responsável pelo povoamento recente e por fazer surgir um novo gênero de vida, o agricultor, ao atrair o japonês do interior e o homem do litoral, ainda indeciso em se libertar do mar. A autora identifica e descreve quatro zonas produtoras de banana, "cada uma com métodos de trabalho diferentes, quanto sistema de exploração e de transporte, que lhe dão aspectos particulares." (CARVAlHo, 1944, p. 121): “arredores de Santos, São Vicente e Guarujá” (p. 121-122), “leste 
de Santos, no vale do Jequeriquerê, praia de Caraguatatuba" (p. 122-125), "sul de Santos, às margens do Itanhaém e seus dois afluentes" (p.125-127) e "mais ao sul, ao longo dos trilhos da Sorocabana" (p. 127-129). Fora a última região, de colonização japonesa, o sistema que prevalece é o de plantation, com grande precarização do trabalho. As técnicas de plantio seguem sendo toscas e levam o solo ao rápido esgotamento, forçando o sitiante a abandonar a lavoura e partir para outra área, assim como faz o fazendeiro de café.

Encerrando a Parte 2, a autora descreve o histórico de ascensão e queda ou estagnação das principais cidades do litoral e destaca o papel dos meios de comunicação nesse processo.

Na parte final de seu trabalho ("Parte 3. Santos, um porto, uma cidade", p. 144-203), Maria da Conceição Vicente de Carvalho finalmente se debruça sobre o Porto e a cidade de Santos, como uma especificidade do litoral paulista. "A presença da cidade explica-se apenas pela existência do porto; por muito tempo ela dependeu exclusivamente dele." (CARVALHO, 1944, p. 144) A autora insistirá em diferentes momentos que o desenvolvimento do Porto não se liga ao desenvolvimento de São Paulo, mas à expansão da cultura cafeeira no planalto paulista, mediada pela ferrovia. "Até a construção da estrada de ferro, Santos não se destacava dentre os vários portos do litoral paulista. A estrada de ferro foi o fator essencial do desenvolvimento do porto, que faz seu comércio exterior sem a influência do porto do Rio de Janeiro." (CARVALHO, 1944, p. 155)

Ao debruçar-se sobre seu objeto principal de análise, como já apontado, Carvalho parece oferecer sua maior contribuição em termos teóricos quando procura demonstrar a falibilidade do determinismo geográfico. Fundamentalmente, é o único momento em que a autora não se restringe a descrever, mas também dialoga com uma questão teórica atinente à Geografia.

O fator localização, em relação à zona produtora de café, é apontado por Carvalho como decisivo para tornar o Porto de Santos o primeiro porto aparelhado do país, em meio a um marasmo de "pequenos burgos estagnados" (p. 173), remanescentes de uma época mais próspera.

Fechando seu trabalho, a autora dedicará sua atenção à geografia urbana de Santos, em estilo igualmente descritivo, tipológico e funcional. Realiza um percurso descritivo a partir da situação e do sítio da cidade, do processo histórico de ocupação da ilha, recuperando diversas passagens da tese e destacando marcos arquitetônicos importantes, até chegar ao nível da paisagem e da função dos principais bairros, após as transformações sanitaristas e o desenvolvimento urbano mais amplo. 
Por fim, Carvalho aponta o aumento de complexidade da economia santista, para além do comércio do café. A atenção a questões demográficas é limitada a apontar a evolução populacional. Sua conclusão está pautada na revisão dos pontos descritos, sem nenhum tipo de consideração teórica final.

\subsubsection{Civilização no meio tropical e progresso, em Araújo Filho (1950)}

Além de Carvalho (1944), que dedicou sua tese ao estudo do litoral paulista, de um modo geral e, especificamente, ao Porto e à cidade de Santos, também José Ribeiro de Araújo Filho se dedica ao litoral, porém, debruçando-se sobre uma área mais restrita. Sua tese intitulada A baixada do Rio Itanhaém. Estudo de Geografia Regional, defendida em 1950, foi a primeira em Geografia sob a brigada da Faculdade a ser orientada por um orientador brasileiro, o Prof. Aroldo de Azevedo ${ }^{144}$. Araújo Filho fala na origem recente de trabalhos “dentro do espírito geográfico" dedicados ao litoral paulista e sobre a "unidade geográfica da região": "De fato, dentro das várias paisagens oferecidas pelo Estado de São Paulo, o litoral forma um todo à parte, com aspectos próprios, que física, que antropogeograficamente falando.” (ARAÚJO FILHO, 1950, p. 1) O autor passa em revista a identificação já comum de duas sub-regiões: Norte e Sul,

que tem Santos e seus arredores como zona de contato. [...] Vamos encontrar neste último [Sul], ao lado de certos característicos gerais permanentes, alguns aspectos particulares, que dão nascimento a sub-divisões, onde aparecem zonas individualizadas. (ARAÚJO FILHO, 1950, p. 2)

A Baixada de Itanhaém seria uma dessas zonas individualizadas, mercê do isolamento em relação ao planalto, a Santos e, mais ainda,

jamais ter possuído uma riqueza no passado, forma uma zona à parte, dentro da subregião a que pertence, caracterizada pela bacia hidrográfica do Itanhaém, pela baixada com depósitos quaternários e pelos mangues, jundus e florestas. (ARAÚJO FILHO, 1950, p. 3)

Vê-se que seu recorte sub-regional, a baixada do rio Itanhaém, está dado a partir de critérios naturais. Como uma das justificativas para seu objeto de estudo, ainda na introdução,

\footnotetext{
144 “O candidato aprovado com distinção, com a média 9,16 foi examinado pela seguinte Banca: Prof. Dr. Aroldo de Azevedo, Professor Catedrático de Geografia do Brasil - Presidente; Prof. José Veríssimo da Costa Pereira, Geógrafo Especializado do Conselho Nacional de Geografia e Chefe da Secção Centro-Oeste do mesmo Conselho; Prof. Dr. Alfredo Ellis Junior, Professor Catedrático de História do Brasil da Fac. de Filosofia, Ciências e Letras da Universidade de S. Paulo; Prof. Dr. João Dias da Silveira, Professor de Geografia Física da mesma Faculdade; e, Prof. Dr. Ary França, professor da Cadeira de Geografia Humana da mesma Faculdade todos membros da Comissão Examinadora.” (PENTEAdO, 1950, p. 593)
} 
Araújo Filho aponta, segundo comentário de Antônio Rocha Penteado, o “interessantíssimo problema da 'marcha para o oeste', tentativa moderna de colonização do Brasil Central" (PENTEAdO, 1950, p. 594), que teria sido, inclusive, tema de crítica construtiva entre os professores da banca examinadora. Assim, segundo Araújo Filho:

Já é tempo, pois, de fazermos qualquer coisa em prol de zonas que, mesmo difíceis
de serem trabalhadas, estão em situação privilegiada, quando comparadas com as
longínquas terras do Centro-Oeste e da Amazônia. [...] Povoando nossas baixadas
litorâneas, estaremos não só criando novas riquezas, como, particularmente, provando
que nas zonas tropicais também o homem branco pode criar civilizações. [...]
E assim, a Baixada do Itanhaém continua a desafiar a reação do homem, à espera de
que este, mudando o método de trabalho, reaja de fato, criando ali uma paisagem
verdadeiramente humanizada. (ARAÚJO FILHO, 1950, p. IV/V)

Esta passagem pontua uma série de elementos relevantes no discurso do autor. Em primeiro lugar, um exemplo cabal do caráter utilitário da Geografia e uma crítica direta, ainda que não explorada ao longo do texto, à transferência da capital federal para o Planalto Central, provavelmente a maior preocupação dos geógrafos do CNG no final dos anos 1940 e também um dos serviços geográficos que lograram maior êxito.

A baixada do Itanhaém é um dos muitos exemplos de baixadas tropicais, que o litoral brasileiro oferece, com toda a série de problemas que o quadro natural, ainda não vencido pelo homem, deixa perceber. Justamente num momento em que tanto se fala na penetração do interior, simbolizada na tão explorada frase "a marcha para o oeste", é interessante mostrar que temos ainda muitas terras para explorar na retaguarda, em zonas que, embora palmilhadas pela colônia, ficaram à margem da valorização. Mercê de uma série de circunstâncias. O curioso é que a maioria dessas zonas marginais se situa à beira-mar, particularmente no litoral paulista, porta de entrada da mais rica região brasileira. (ARAÚJO FILHO, 1950, p. II, grifo nosso.)

Em que pese o baixo conteúdo crítico das proposições relativas às preocupações nacionais da época, não se trata de um estudo desvinculado do contexto nacional, mas atrelase, mesmo, à possibilidade de uso econômico mais racionalizado do meio geográfico. ${ }^{145}$ À possibilidade de melhor exploração de terras próximas à região econômica mais importante do país, soma-se um forte discurso civilizatório do meio tropical, polvilhado de racismo, além de uma forte esperança no progresso das forças produtivas, desamparada de uma análise em termos econômicos ou sociais. Estes dois elementos, o discurso civilizacional do homem branco sobre o "meio hostil" e a expectativa no progresso - com o qual sua monografia pode vir a contribuir -, estão mais nitidamente expostos do que nas demais teses consultadas.

$145 \mathrm{O}$ autor faz uma curiosa referência ao deslocamento de grandes contingentes humanos por regiões tipicamente tropicais pelas Nações Unidas, em decorrência da $2^{\mathrm{a}}$ Guerra Mundial, do que teria surgido "a vontade do homem branco de aproveitar, da melhor maneira possível, as zonas tropicais, principalmente as situadas nas proximidades de litorais." Exemplo não seguido pelo Brasil, devido à famosa marcha para o oeste. (ARAÚJO FILHO, 1950, p. III-IV) 
Araújo Filho destaca a pequena importância econômica e demográfica do litoral e a atribui à difícil localização do sítio, mas evita versar sobre o que já foi estudado no âmbito da ciência geográfica. Defendida em 1950, a tese já pode usufruir de uma bibliografia endógena à ciência geográfica. "Não vamos aqui explicar as razões da pequena importância da região litorânea na atualidade, porque, em trabalhos publicados por estudiosos da nossa geografia, isto já foi feito.” (p. 2) Suas referências básicas são Carvalho (1944), Deffontaines (1935) e França (1944).

A descrição de um meio hostil dá a tônica principal de seu texto. "Rios em abandono, florestas alagadiças, sob um clima quente e super-úmido e onde a malária campeava, tudo ali dava a ideia de sertão bruto. Era uma paisagem tipicamente tropical, no ambiente e no cenário, desafiando a penetração humana.” (ARAÚJO FILHO, 1950, p. I, grifos do autor) Associadas à rudeza do sertão, porém, as técnicas atrasadas do caiçara - um dos tipos humanos tradicionais "que à primeira vista parece simplesmente indolente, mas que, na realidade, é um sub-alimentado e um doente" (ARAÚJO FILHO, 1950, p. 42) - não permitem superar o quadro de estagnação e atraso. O caiçara é o homem-tipo da região, que parece carregar os mesmos valores de seus antepassados longínquos.

[A] impressão que se tem, logo à primeira vista, é que esse tipo de praiano não admite modificação no que ele herdou de seus avoengos: um gênero de vida primitivo e de acordo com o meio hostil que o rodeia. De fato, observando-se de perto o caiçara paulista, vê-se logo a inferioridade em que ele se encontra quando comparado com o caboclo planaltino e mesmo com outros tipos praianos, como os do Nordeste brasileiro. [...]

O caiçara, tipo que até hoje está à margem da civilização, mesmo quando teve ocasião de entrar em contato com o progresso, nada aproveitou. É que sobre ele pesam mais de dois séculos de vida rudimentar e de abandono. (ARAÚJo FILHO, 1950, p. 40/41)

O autor, então, dedica-se a descrever o desenvolvimento das plantações de banana no litoral e estabelece, mesmo, um paralelo positivo com o fenômeno do avanço das plantações de café, que no planalto paulista redundaram em geração de progresso e riqueza. O negócio da banana se atrelou ao papel de desbravamento e o caso de Itanhaém seria mais um exemplo “deste pioneirismo destruidor":

Por exemplo, no litoral as terras são "griladas" como as do planalto; também elas são ocupadas pela lavoura extensiva para fins comerciais, de maneira que glebas devassadas há 10 ou 15 anos são logo deixadas para trás como pouco produtivas, à medida que se vai avançando num desbravamento sem limites. (ARAÚJO FILHO, 1950, p. 94)

Em todo o Capítulo IV (“A economia regional”) de seu trabalho, ao descrever as etapas da cultura da banana e das técnicas utilizadas (vide ANEXO D), o autor reitera "os bisonhos 
métodos de exploração da terra praticados pelo nosso agricultor" (p. 115) e a necessidade de melhor trato com a terra, que "não nos é dada apenas pela natureza; ela é também conseguida pelo próprio esforço do homem, que, à custa da técnica pode fazer milagres." (113)

Infelizmente, porém, assunto de tanta importância para qualquer região, mormente para as brasileiras, a sua maioria sob climas tropicais, não foi ainda levado em conta pelos nossos agricultores. Já pela ignorância, já por desleixo, às vezes por uma economia descabida, o fato é que, até agora, poucos foram os nossos lavradores que deram à terra os cuidados que ela merece. (ARAÚJO FILHO, 1950, p. 113)

Nesse sentido, José Ribeiro de Araújo Filho indica que o desenvolvimento dos bananais pode, à semelhança do desenvolvimento da economia cafeeira, gerar riqueza para uma região à margem do progresso experimentado pelas frentes pioneiras, mas próxima do principal centro econômico do país. O autor parece filiar seu trabalho como um contributo à consecução deste objetivo, na medida que apenas com o necessário planejamento econômico se poderia superar não apenas o meio hostil, como também as técnicas ultrapassadas de plantio.

\subsubsection{Padrões de paisagem caipira, segundo Müller (1951)}

Nice Lecocq Müller, autora da tese intitulada Sítios e sitiantes no Estado de São Paulo, defendida em 1946, afirma nas páginas iniciais que "nada há de menos definitivo e estático do que a Geografia" (MüLLER, 1951, p. 15) e oferece o trabalho menos restrito ao estudo de uma região, em si, em comparação às demais teses analisadas. ${ }^{146}$ Nesse sentido, tratar-se-ia, aliás, do trabalho menos "geográfico" consultado, no sentido proposto por Lacoste (2012, p. 58) de “descrição de paisagens historicamente constituídas de fatores naturais e humanos”, embora a autora se filie aos estudos de Geografia Humana, "que tem por escopo o estudo das interrelações entre as sociedades humanas e os fatores do meio natural”. (MÜLLER, 1951, p. 11) O cerne de sua análise repousa no surgimento de um novo elemento - o caipira, pequeno produtor policultor - em paisagens antigas dominadas pela monocultura do café, fazendo surgir novas paisagens e novos gêneros de vida. Mas a autora não se furta a fazer referências a aspectos da natureza e relacioná-los ao processo de ocupação humana e busca, com frequência, em geral na parte inicial ou final de cada capítulo, explicitamente justificar o

\footnotetext{
${ }^{146}$ Para Müller (1951, p. 13), não se trata de uma monografia regional, pois não fornece meios de comparação, já que não há outras monografias do gênero. A autora expressa o desafio de se realizar uma pesquisa individual que oferecesse possibilidades de trabalho cientifico. Aparentemente, a comparação e a generalização dela resultante referendaria a natureza científica do trabalho.
} 
conteúdo geográfico de sua análise. É o caso, por exemplo, da introdução ao Capítulo IV, denominado "Técnica e ritmo de trabalho do sitiante", na qual afirma a autora:

Assunto difícil e delicado, pois que ao mesmo tempo está ligado ao homem, ao meio e, evidentemente, aos vários tipos de inter-relações resultantes, é, por isso mesmo, marcadamente geográfico. (MÜLLER, 1951, p. 75)

A complexidade de múltiplos fatores em relação parece ser uma característica definidora do saber geográfico. Também no início do Capítulo VII, "A casa do sitiante", Müller (1951, p. 145) afirma que a casa do sitiante, entendida como a moradia e as benfeitorias, "é parte de seu trabalho e das paisagens por ele criadas; reflete seu nível de vida e é um dos traços de sua personalidade geográfica. Não poderia, porisso, ser ignorada em nosso estudo." Ao final do capítulo, também intensamente tipológico e classificatório, ela justifica sua análise, em termos de relevância geográfica:

Apareça ela em bloco ou em dissociação de dependências, é sempre um fato geográfico: pelo material liga-se às possibilidades do meio, pela construção às possibilidades técnicas do sitiante e pelo planejamento ao tipo de produção e de ocupação do solo. (MüLLER, 1951, p. 166)

Chama a atenção o grande número de fotografias de residências neste capítulo: são 28 no total, indicando a importância da análise da paisagem para a compreensão do objeto de estudo. Apesar da constante busca pela análise da paisagem, Müller parece aproximar-se mais da Antropologia do que da Geografia, na medida que sua tese repousa, eminentemente, na compreensão do modo de vida do "sitiante" e nas relações sociais constituídas em "nosso mundo rural" - em referência ao território paulista, indicando um recorte de estudo estabelecido a priori, como se fosse óbvio que seu trabalho se restringisse a São Paulo. O ambiente rural, aliás, é privilegiado em seu estudo, já que se trata do "domínio em que as inter-relações geográficas são mais diretas” (MÜLLER, 1951, p. 16). Segundo a autora, o pivot da transformação da paisagem monótona da monocultura cafeeira

foi o fracionamento da propriedade e o desenvolvimento da policultura. Para estudála seria preciso, segundo cremos, partir do novo tipo de homem rural que agora toma pé e conquista seu lugar ao sol: o pequeno produtor policultor, ou seja, o sitiante. [...] [...] o que nos propomos fazer é estudar quem é este sitiante do ponto de vista geográfico, ou seja, como se distribui, de eu forma ocupa a terra, qual o seu gênero de vida, quais as paisagens por ele criadas. (MÜLLER, 1951, p. 13)

Assim como outros geógrafos de sua geração, Müller demonstra preocupação com a recíproca relação entre fatores humanos e naturais na composição da geografia terrestre:

Quando não são as condições naturais, são as possibilidades do homem que podem mudar: lidamos com fatores essencialmente dinâmicos e tão ligados entre si, que um não poderá modificar-se, sem influir no outro. (MÜLLER, 1951, p. 15) 
Considerado por vezes uma limitação a um conhecimento que reclama cientificidade; origem de históricas confusões teóricas; alimento, ainda, para definições pouco claras quanto ao objeto de estudo, o difuso posicionamento teórico-metodológico da ciência geográfica, evidente em diversos clássicos consultados, parece ser uma resistência à compressão de tipos humanos desvinculados de uma complexa teia de relações com seu meio, ou a compreensão deste sem se levar em consideração o trabalho humano. ${ }^{147}$ A definição geográfica de "sitiante" de Müller, por exemplo, considera apenas os critérios que levam a alterações na paisagem. As teses de doutorado - mais do que os materiais em geral mais pragmáticos publicados na RBG - apesar da despreocupada reprodução em termos teórico-metodológicos do modus operandi da ciência geográfica, reforçam amplamente uma preocupação com a integralidade do fenômeno estudado, via de regra a partir de uma perspectiva antropocêntrica. Para Nice Lecocq Müller o conceito de região parece estar essencialmente relacionado à ocupação humana, em função do avanço de relações de produção e da introdução, ou não, de novas formas de exploração da terra.

O que se evidencia com clareza é a natureza tipológica e classificatória do trabalho de Müller, com uma perspectiva de generalização de padrões de distribuição e feições paisagísticas em função de um determinado número de fatores naturais e humanos. Pode-se falar, em suma, de padrões de organização do espaço em uma surpreendente apreensão do quadro humano e paisagístico. A autora, além disso, se preocupa constantemente em classificar os elementos constitutivos de seu objeto de análise, dando uma forma bem delineada ao seu discurso. Seu trabalho ganha potencial teórico, nesse sentido, ao servir de base analítica para outros estudos similares, a partir do fortalecimento do discurso geográfico. A questão, nos dias atuais, é como se apropriar de tal forma de apreensão do meio geográfico para a construção contemporânea de teorias comprometidas com a dinâmica da realidade.

Parte do potencial crítico do trabalho de Nice Lecocq Müller repousa, talvez, também na escolha do objeto. Ao não centrar seu objeto em uma região mas em um conceito, o sitiante, e frente à latente questão agrária brasileira, a autora transcende ao registro de testemunhos geográficos e propõe uma definição de sitiante baseado na exploração direta da terra que, com efeito, tornou-se referencial teórico básico para estudos relativos ao mundo

\footnotetext{
147 O próprio Prof. José Bueno Conti afirma: "Pertencendo, ao mesmo tempo, ao domínio das ciências da terra e das ciências humanas, a geografia tem por objeto próprio a compreensão dos processos interativos entre natureza e sociedade, produzindo, como resultado, um sistema de relações e de arranjos espaciais que se expressam por unidades paisagísticas identificáveis em todas as escalas de grandeza." (CONTI, 2014, p. 240) O cerne de tal definição, como tantas outras, é vaga e incapaz de apreender a especificidade da Geografia como ramo científico. Segundo tal definição, mais adequado não seria centrar o objeto da ciência geográfica sobre o "sistema de relações e de arranjos espaciais", uma vez que a relação sociedade-natureza é - ou deveria, explicitamente, em termos teóricos - , de todo modo, base para todos os ramos de conhecimento?
} 
rural. Assim, a leitura, em si, da paisagem, perde importância enquanto objeto central da análise para se tornar um importante elemento compósito de um quadro histórico-geográfico maior.

No item final de seu trabalho, capítulo IX, "O sitiante e a paisagem”, Müller faz uma comparação entre as diferentes paisagens criadas pelo sitiante:

\footnotetext{
$\mathrm{Na}$ frente de colonização a paisagem se apresenta como uma combinação de matas derrubadas, queimadas recentes [...] à medida que se regride para a retaguarda a paisagem é menos natural e mais cultural [...] finalmente, na retaguarda, chega-se a paisagens bem humanizadas, com ocupação do solo perfeitamente demarcada. (MÜLLER, 1951, p. 185)
}

É interessante assinalar o dinamismo da paisagem analisada, na medida em que se descreve as transformações ocorridas na mesma em função das transformações das atividades do sitiante. Seu trabalho se insere, também, na esfera da Geografia Econômica e da Geografia dos Transportes e da Circulação, na medida em que vias de comunicação e possibilidade de comércio tendem a alterar a estrutura econômica na qual o sitiante se insere. "É assim que vamos encontrar estreita relação entre a vida econômica do sitiante e dois fatores geográficos: distância e meios de comunicação.” (MÜLLER, 1951, p. 110)

\subsubsection{Cartografia da evolução da paisagem, segundo Mendes (1948)}

Em termos de leitura de paisagem, embora traço metodológico essencial de todas as primeiras teses defendidas junto ao DG-USP, encontramos no trabalho de Renato da Silveira Mendes um dos legados mais impressionantes. Intitulada Paisagens culturais da Baixada Fluminense, a tese defendida em 1948 é a única dedicada a uma região integralmente fora do estado de São Paulo e, certamente, a mais rigorosa em termos de aplicação do método regional. É válido afirmar-se desde já que, com a tese de Mendes, torna-se nítido que uma das maiores contribuições, no plano do pensamento geográfico, que estes mestres fundadores da Geografia acadêmica paulista podem dar reside mais no plano do método do que no da teoria. José Bueno Conti, ao comentar o trabalho de Renato da Silveira Mendes, afirma:

Esse trabalho se tornaria antológico pela maneira inteligente como caracterizou e interpretou a diversidade paisagística das regiões litorâneas e sublitorâneas do Estado do Rio de Janeiro, produto, ao mesmo tempo, das condições de tropicalidade, das características da cultura, da economia e das relações de produção dominantes naquele momento. O grande valor do trabalho está na forma cuidadosa com que analisa a elaboração das paisagens a partir das características do meio físico e sua evolução ao longo da história demonstrando como a geografia, enquanto ciência que estudo o espaço transformado, é sempre produto do processo interativo entre 
sociedade e natureza. Ilustra a pesquisa com 93 fotos, documentação excepcionalmente rica para os padrões da época. (CONTI, 2014, p. 243, grifo nosso.)

De fato, a estrutura metodológica e de apresentação do trabalho impressiona pela riqueza ilustrativa e a minuciosa descrição paisagística complementada por uma rara sequência de mapas, decerto motivos de orgulho ao Departamento de Geografia da USP. Esta estrutura, contudo, ancorada em minuciosas descrições históricas e contemporâneas das paisagens em associação a dezenas de fotografias e mapas rigorosamente elaborados, parece ser também a maior contribuição que o trabalho tem a dar. Já na terceira parte de seu trabalho, “As paisagens modernas", (vide ANEXO D) o autor registra as alterações nas paisagens culturais da região estudada através de uma sequência de mapas por ele elaborada que, em conjunto, formam um contínuo que fornece um panorama evolutivo da paisagem. Esta é a essência de seu trabalho, seu maior legado. Sua riqueza está, pois, na forma. Em todo o restante de sua pesquisa, o autor se limitará a descrever as paisagens apresentadas.

$\mathrm{Na}$ introdução de seu trabalho, Mendes (1950, p. 17) afirma que um "estudo regional, o mais completo possível, da Baixada seria em verdade um magnífico tema para a tese”, porém, sua especialização e a carência de cartas topográficas e estudos diversos sobre clima, vegetação, solos etc. inviabilizam tal empreitada. "Um importante aspecto a ser encarado no estudo da paisagem cultural, aspecto esse acentuado pelos geógrafos que mais se dedicaram à conceituação da ciência geográfica, consiste na evolução da paisagem.” (MENDES, 1950, p. 18) Cita-se o "princípio de atividade" de Brunhes e a morfologia da paisagem de Sauer, que apontam que a paisagem humanizada também se modifica com o tempo, "em função das diferentes civilizações que ocupam uma determinada região.” Explicita então o autor seu objeto de estudo:

Baseando-nos, pois, nessas modificações da paisagem procuramos reconstituir as várias fases da ocupação do solo na Baixada Fluminense, descrevendo e interpretando as paisagens culturais correspondentes a esses períodos. (MENDES, 1950, p. 19)

E este objetivo será rigorosamente perseguido. Mas o geógrafo alerta:

Abordando dessa forma as paisagens culturais da Baixada absolutamente não esgotamos o assunto, pois dedicamo-nos de preferência ao quadro rural. [...] Limitando, portanto, a maior parte da nossa tese à paisagem rural, abordamos aquelas que acreditamos ser onde as relações entre homem e meio físico são mais evidentes. (MENDES, 1950, p. 19)

Sua justificativa para restringir-se a paisagens rurais é idêntica à dada por outros doutorandos da época, como por Müller (1951). O autor considera a Geografia Urbana de tal ordem complexa que monografias sobre cidades localizadas na Baixada "estariam 
perfeitamente enquadradas dentro do estudo das paisagens culturais da Baixada." (MENDES, 1950, p. 19)

Isto posto e sem justificativas quanto à escolha do local de estudo, prosseguirá o autor com a descrição da área em um trabalho dividido em três partes. Na primeira parte, "Aspectos físicos e divisão regional da Baixada Fluminense”, efetuará uma descrição sumária da área de estudo, com indicativos quanto ao seu limite. Vale ressaltar que se trata de um dos limites mais claramente expostos, dentre as teses consultadas. Prosseguirá, então, com uma descrição do relevo - o autor define as principais formas de relevo encontradas, localiza-as e as descreve sumariamente quanto à forma, à geologia e à composição pedológica -, clima e vegetação. Sua descrição também se dá em termos antropocêntricos e a procura por características favoráveis ou limitantes à ocupação humana é constante.

O papel desempenhado por essas colinas [as meias-laranjas] de poucas dezenas de
metros de altitude na conquista da região pelo homem foi dos mais notáveis, pois
serviram de ponto de apoio para a fixação do colonizador que dificilmente poderia
se localizar nas planícies periódicas inunáveis. [...]
O conjunto dos aspectos físicos que descrevemos imprime à Baixada Fluminense
uma fisionomia própria que se destaca na faixa litorânea do Brasil e permite
considerá-la como uma verdadeira região natural. (MENDEs, 1950, p. 23/31)

O Capítulo 2, “As sub-regiões", ainda pertencente à primeira parte da monografia, é o que mais se aproxima de uma preocupação metodológica, ao procurar-se identificar uma divisão sub-regional para a Baixada Fluminense. Esta preocupação não é, aliás, original, tendo em vista que Mendes cita as propostas de divisão regional da Antiga Comissão de Saneamento segundo bacias hidrográficas; de Pierre Deffontaines e Fróes de Abreu para todo o Rio de Janeiro; de Everardo Backhauser em tese enviada ao IX Congresso Brasileiro de Geografia, segundo antigos focos de povoamento que correspondem a diferentes aspectos fisiográficos; e do CNG que procurou harmonizar características físicas e humanas sob o ponto de vista administrativo.

A Baixada Fluminense, embora constitua uma unidade sob o ponto de vista
geográfico, diferenciando-se nitidamente de outros trechos do litoral brasileiro, não
é, entretanto, uniforme. Determinadas condições locais imprimem à paisagem
natural e cultural diferenciações que possibilitam a distinção de zonas ou sub-
regiões tanto do ponto de vista fisiográfico como do antropogeográfico. (MENDES,
1950, p. 33)

Do texto depreende-se que o "ponto de vista geográfico" é sinônimo de geografia física, inclusive pelo fato de o autor ainda não ter definido os limites regionais do ponto de vista 
cultural/humano. ${ }^{148} \mathrm{O}$ autor propõe nova divisão regional. Como ponto de partida, propõe "encarar apenas os elementos naturais que as individualizem." (MENDES, 1950, p. 35) Resulta-se em 12 zonas fisiográficas, que o autor nomeará e descreverá sumariamente. Tais zonas, contudo, não resolvem o problema bastante complexo da divisão regional. Em primeiro lugar, seria impossível delimitar-se precisamente sub-regiões naturais, já que a transição entre as zonas se dá de maneira "insensível”. Os limites entre as zonas seriam, pois, esquemáticos.

O autor propõe, entretanto, a adoção de outro critério para a divisão regional, já que o natural lhe parece acadêmico e artificial, fugindo à própria realidade. A região, nesse sentido, não se auto-evidenciaria.

Devendo considerar-se nos estudos geográficos os dois elementos - meio e homem - não seria preferível partir do elemento humano e não do quadro físico para se efetuar a classificação das regiões? (MENDES, 1950, p. 38)

Como critério de divisão sub-regional, Mendes parece se aproximar de Deffontaines (1945), ao procurar no saber popular a identificação de unidades regionais:

\begin{abstract}
A noção de região ou 'país' existe na mente dos moradores de uma determinada área qualquer que seja o seu grau de cultura e independe, portanto, dos conhecimentos científicos a respeito dessa região. [...] Acreditamos, portanto, ser preferível para os estudos regionais efetuar-se a classificação ou subdivisão em zonas de acordo com o conceito local, isto é, com a noção de região ou 'país' dos próprios habitantes e não tentar enquadrar essas zonas considerando-se apenas os aspectos físicos. (MENDES, 1950, p. 38)
\end{abstract}

O autor exalta a percepção já bastante antiga de pelo menos três sub-regiões e a consciência ou ideia de "país" no sentido atual de região entre os antigos moradores da região. Mendes exalta, inclusive, o uso da "expressão 'paiz"” [sic] com o sentido de região e "mesmo de 'pequena pátria'”. (MENDES, 1950, p. 39)

Acreditamos, portanto, que a Baixada Fluminense deve ser dividida não apenas em "zonas fisiográficas" mas em verdadeiras "sub-regiões geográficas", isto é, em "países", termo atualmente em desuso, ou melhor, aplicado entre nós em relação a unidades políticas estatais. [...]

Uma região geográfica ou "país", ao nosso ver, deve considerar não somente os elementos naturais que lhe são peculiares mas principalmente o elemento humano que, utilizando-se dos recursos locais e dando a áreas fisicamente diferentes uma certa unidade pelo povoamento, ocupação do solo, vias de comunicação, é quem na realidade "cria" a região. (MENDES, 1950, p. 39/39-40. Grifos nossos.)

Já nesta passagem, para o autor, "zona fisiográfica" não é sinônimo de "região geográfica", na medida em que, conforme se evidencia com as passagens destacadas, o

\footnotetext{
148 Tal sinonímia está presente em Müller (1951), Santos (1999) e outros autores, aparentemente por descuido ou falta de rigor conceitual. Em Müller (cf. p. 173), tal sinonímia é pontual, já que em diversas situações a definição do geográfico perpassa elementos não-naturais. Em Santos, por outro lado, trata-se, efetivamente, de um posicionamento teórico, ao nosso ver, criticável.
} 
elemento humano é efetivamente quem estabelece unidade entre fatores díspares. "Cada 'país' pode conter mais de uma zona natural, pois justamente o aproveitamento de recursos de zonas diferentes é que determina a interpenetração e a unidade regional.” (MENDES, 1950, p. 40) Desse ponto de vista, caberia ao pesquisador identificar na paisagem as regiões criadas e harmonizadas pela história social, mas do ponto de vista do método, a pesquisa se inicia com a exposição dos quadros naturais, já que estes fornecem os recursos a serem aproximados e colocados em relação pelas técnicas humanas.

Vencida a primeira parte do texto, as partes dois e três tratam de descrever, em termos históricos ("Segunda Parte”) e contemporâneos ao autor (“Terceira Parte”) as paisagens culturais fluminenses por ele identificadas. (vide ANEXO D) Baseado em princípios geográficos tradicionais, o autor descreve cartograficamente diferentes atividades econômicas, em diferentes períodos históricos, cujo acúmulo de estruturas - permeado de avanços e retrocessos - resultaria nas paisagens existentes em sua época.

Por exemplo, através de documentos históricos diversos, especialmente mapas antigos, Renato da Silveira Mendes reconstitui a paisagem da Baixada Fluminense durante o surto canavieiro que perdurou do declínio da mineração à meados do século XVIII, em um exercício de descrição cartográfica da paisagem, através da identificação do uso do solo e da localização e distribuição de atividades e construções diversas. Este exercício se estende por todo o final do item 2 , do capítulo 1 , da segunda parte. ${ }^{149}$

Neste exercício, há espaço, evidentemente, para importantes considerações, no âmbito descritivo, à geografia da circulação e dos transportes, já que as inter e intra-relações de complementaridade, produção e consumo que se estabelecem entre diferentes zonas fisiográficas e regiões históricas se dão por meio de modais de transporte, que se complementam, competem e se sucedem ao longo do tempo.

Ao final do capítulo 1 da terceira parte, Mendes dá a tônica do restante de seu trabalho e faz uma pontual consideração teórica. Segundo o autor, as cartas de ocupação contemporânea (à época) do solo, de distribuição da população e de repartição do solo em lavouras, pastos e matas "nos forneceram, em síntese, uma ideia de como houve uma diversificação regional na Baixada Fluminense em consequência da implantação de determinadas atividades econômicas.” (MENDES, 1950, p. 95-96) Foi baseado nesta diferenciação que o autor traçou o mapa básico das sub-regiões, "as quais correspondem muito mais às paisagens elaboradas pelo homem do que ao quadro natural." (MENDES, 1950, p. 96)

${ }^{149}$ Cf. Mendes, 1950, p. 49-59, em especial, a partir da p. 53. 
A análise regional, igualmente, deve estar associada ao estudo das paisagens culturais ou humanizadas. No presente capítulo [um, terceira parte] vimos em conjunto e comparativamente a ocupação do solo. Entretanto o estudo, ou melhor, a análise das paisagens regionais se torna indispensável; nos capítulos seguintes [dois a quatro], ao abordarmos esse estudo, veremos nitidamente que os vários tipos de ocupação do solo relacionados com determinadas atividades econômicas são os principais elementos que caracterizam e diferenciam as paisagens modernas da Baixada Fluminense. (MENDES, 1950, p. 96)

Esta última conclusão geral, baseada na associação entre ocupações do solo e a respectivas atividades econômicas, resultando em diferenciação da paisagens, e que dará a tônica dos três capítulos finais da tese, é óbvia. Constitui, no entanto, um dos poucos momentos de desenvolvimento teórico do autor, para além dos registrados na primeira parte. Nas páginas seguintes e finais, o autor trata das paisagens regionais, encaradas como dimensões da realidade, a partir da identificação, descrição e interpretação, por exemplo, da "paisagem natural das montanhas" e da "paisagem cultural das baixadas"150, e falará em "unidade da paisagem", paisagem "sui-generis" - constituída por uma faixa semi-urbana e outra semi-rural - e "vocação do meio geográfico".

\subsubsection{Santos (1951) e a justificação antropocêntrica de seu estudo}

As atividades econômicas, especificamente, estão na base da justificação do trabalho da candidata à doutora em Geografia Física, Elina de Oliveira Santos. Intitulado A industrialização de Sorocaba: bases geográficas, o trabalho foi defendido em 1951 e, em uma rara ação de resgate e preservação, republicado em 1999. ${ }^{151}$ Durante e após a leitura de seu trabalho e, comparando-se com trabalhos do âmbito da Geografia Física publicados recentemente ${ }^{152}$, não deixa de chamar a atenção o fato de o trabalho se inscrever na referida subárea. Segundo José Bueno Conti, no "Prefácio" da republicação, a tese de Elina Santos:

Extrapola os limites de um estudo geomorfológico, constituindo uma caracterização bem feita do quadro natural, mostrando a complexidade de seus processos interativos e as vinculações com a vida humana e econômica, ou seja, realizou um trabalho geográfico no sentido pleno. (CONTI, p. 15 In: SANTOS, 1999)

\footnotetext{
150 “A planície de Maricá e Saquarema, localizada entre as restingas, as lagunas e o Maciço montanhoso, não é somente a vida de comunicação natural mas também a área em que a ocupação do solo pelo homem foi mais ampla. Desse fato decorre o notável contraste oferecido pela paisagem natural das montanhas e a paisagem cultural das baixadas. [...] Assim, enquanto os taludes das montanhas se apresentam revestidos de densas florestas, a paisagem da planície indica por toda a parte a presença do homem.” (MENDES, 1948, p. 130/130-1) ${ }^{151}$ SAntos, Elina de Oliveira. A industrialização de Sorocaba: bases geográficas. São Paulo: Humanitas, 1999 , 183p. (Série Teses) Vale destacar que a própria autora revisou e editou algumas passagens, em relação ao texto original, escrito quase 50 anos antes.

${ }^{152}$ Cf., p. ex., a última edição (v. 30, 2015) on-line da Revista do Departamento de Geografia da USP, disponível em: <http://www.revistas.usp.br/rdg/issue/view/8285>. Último acesso em 2 de maio de 2016.
} 
Ainda segundo o professor, "trata-se de uma obra feita com cuidadoso rigor científico e adequação metodológica, continuando a ser um modelo, apesar do tempo decorrido." (CONTI, p. 16 In: SANTOS, 1999)

A autora elege uma área como objeto de estudo, com base no critério da singularidade. Mesmo critério utilizado por outros autores, chama a atenção a indicação, na Introdução, de que o estudo, de Geografia Física, norteou-se no sentido de indicar as bases do processo de industrialização. Em relação à singularidade da área de estudo, afirma a autora:

A originalidade geográfica do quadro natural da região de Sorocaba decorre de sua posição numa zona de contato geológico e morfológico. Trata-se de uma área onde dois domínios de formas de terrenos, solos, clima e vegetação criaram contrastes nas paisagens e diferenças nas atividades econômicas. (SANTOS, 1999, p. 21)

Morfologicamente, procede-se à transição da região cristalina do Planalto Paulista cristalino a leste, de relevo movimentado, e a região sedimentar da Depressão Periférica a oeste, de topografia suavemente ondulada. A posição geográfica sui generis da região

fez com que ela se tornasse famosa no século passado pela função de mercado, como "feira de burros". Tal posição de cidade-eixo, como a chamou Deffontaines (1939), representou um dos principais fatores geográficos da industrialização regional. (SANTOS, 1999, p. 21-2)

Sorocaba se destaca por ser um polo industrial em meio a uma paisagem agrícola dos municípios vizinhos:

Tendo em vista o fato de o processo de industrialização ter sido o fenômeno mais expressivo, norteamos a pesquisa no sentido de focalizar as bases em que se apoiou. $[\ldots]$

Em contato direto com a realidade geográfica pudemos sentir a maneira pela qual o homem se aproveitou das possibilidades do quadro natural e diferenciou as paisagens regionais. (SANTOS, 1999, p. 22)

Evidente está a importância o trabalho de diferenciação da paisagem, na forma das atividades econômicas, para a justificação do trabalho da autora. Ainda que Elina Santos tenha elegido sua área de estudo em função da necessidade de justificar, a partir do âmbito da Geografia, seu estudo geomorfológico, o fato é que este estudo, do ponto de vista geográfico, apresenta critérios - no caso, antropocêntricos - na escolha desta área de estudo. O estudo geomorfológico se dá em função da ocupação humana que historicamente ali se processou. Ainda que das passagens acima destacadas possa se inferir uma possibilidade de análise dos “contrastes nas paisagens" apenas com base em critérios naturais, aparenta ser uma escolha deliberada da autora - seja por força do contexto histórico-institucional, ou outro - o estudo de uma área não exclusivamente caracterizada por critérios naturais, como o faz também Silveira (1946), mas diferenciada pela atividade humana. 
No item A do capítulo 1 - dedicado às paisagens naturais (vide ANEXO D) -, procede-se a uma descrição da paisagem geomorfológica da região de Sorocaba, relacionando-a com as estruturas geológicas, "a influência litológica nas minúcias topográficas.” (SANTOS, 1999, p. 30) Nesta descrição fica claro que "base geográfica" refere-se aos elementos da natureza, mas a dedicação ao seu estudo está totalmente atrelado ao aproveitamento humano. A autora identifica unidades geomorfológicas e as descreve individualmente. Em todas elas vincula-se a descrição ao aproveitamento humano. ${ }^{153}$ Por exemplo, sobre a Pré-serra de São Francisco, afirma a autora:

[...] Todo esse conjunto pré-devoniano, peneplanizado de há muito, encontra-se hoje bastante reentalhado, oferecendo, nas condições particulares de sua geologia e morfologia, os elementos fundamentais para o desenvolvimento industrial da região de Sorocaba. Assim, na base da exploração mineral originou-se a indústria da cal e do cimento e, graças às condições particulares do relevo e da drenagem do tipo apalachiano, foi possível a construção de represas e barragens necessárias à instalação de usinas hidrelétricas, que propulsionaram a industrialização. (SANTOS, 1999, p. 32)

Elina Santos, a seguir, aprofunda-se na questão geomorfológica em si e dialoga com autores como Ab'Sáber (1949), para então descrever o que ela chama de quadro ecológico: condições climáticas, pedologia e revestimento vegetal. A ausência de dados a faz levantar hipóteses sobre fatores diversos e raramente dissocia os elementos descritos dos fatores humanos. Em termos de análise da vegetação, por exemplo, a autora afirma que a "região de Sorocaba não apresenta praticamente nenhuma formação vegetal de caráter primário. Tudo o que se pode observar é o resultado de um longo passado de ocupação dos solos e de evolução da paisagem.” (SANTOS, 1999, p. 45) As técnicas agrícolas rudimentares seriam o principal responsável pela transformação da paisagem. "O que realmente nos interessa é conhecer suas consequências para a paisagem." (SANTOS, 1999, p. 45) A autora procura na paisagem e na bibliografia indícios para provar que as áreas atualmente de campos e cerrados já abrigaram florestas, através da avaliação de espécies presentes e das próprias plantações presentes nessas áreas.

\footnotetext{
Assim, intensa devastação domina tanto a região cristalina quanto a sedimentar: a paisagem natural tornou-se desoladora, com extensos campos monótonos, ensolarados e desnudos. A mata, no passado, deveria recobrir quase toda a região; sua derrubada entretanto veio constituir fator positivo nos primórdios da industrialização fornecendo combustível barato às pequenas oficinas e fábricas que ali se instalaram. (SANTOS, 1999, p. 48)
}

\footnotetext{
153 As unidades são Serra de São Francisco, Pré-serra de São Francisco, Morros e outeiros graníticos, Relevo tabular dos arenitos, Morro de Araçoiaba e Planícies aluviais do rio Sorocaba, além da própria posição geográfica das várzeas. Cf. Santos, 1999, p. 29-36.
} 
Os demais três capítulos não diferem da descrição monográfica regional já identificada em outros trabalhos. De uma descrição dos elementos naturais, com forte acento antropocêntrico, Elina Santos desloca-se para a evolução da ocupação e das atividades econômicas, do ponto de vista histórico, ancorando-se na bibliografia disponível na época.

Desde há muito fora observado que a faixa de transição entre as regiões cristalina e sedimentar - do Estado de São Paulo revelara-se particularmente favorável ao estabelecimento de núcleos urbanos que se tornaram cidades-mercados graças a sua privilegiada posição geográfica. (Moraes Rego, 1932; Denis, 1927; Deffontaines, 1935; Prado Júnior, 1935; Monbeig, 1941) Sorocaba é um bom exemplo, tendo se destacado no século passado pelas suas famosas "feiras de burros". (SANTOS, 1999, p. 71)

Terá, então, condições para descrever os mesmos elementos em época contemporânea à sua redação. O capítulo final de sua tese é dedicado a uma descrição de paisagens, resultantes, de certa maneira, da associação de todos os elementos apresentados ao longo do trabalho. ${ }^{154}$ Segundo a autora, os ajustamentos biológicos e humanos sobre a zona de contato geológico de uma formação cristalina com uma formação sedimentar resultaram numa multiplicidade de paisagens geográficas.

A autora fala em "fisionomia da cidade", em "aspecto do casario" e em "aspecto fisiográfico", neste último caso concentrando-se em relevo, geologia e solo. Localiza os diversos compartimentos e os descreve. Fala da função de cada distrito dentro da dinâmica municipal e sua evolução histórica, bem como realiza certa crônica da cidade, descrevendo a dinâmica contemporânea.

Na parte dedicada à paisagem regional da região cristalina, por exemplo, Santos afirma:

Se toda essa área sedimentar fosse submetida a um tratamento racional do solo, poderia tornar-se pólo produtor de relativa importância regional. O que parece existir é uma falta absoluta de tradição na ocupação dos solos de campos, sendo também uma questão cultural, como aliás tem observado Waibel (1949 e 1950) em outras regiões do Centro e do Sul do Brasil. (SANTOS, 1999, p. 121)

Trata-se de uma das poucas passagens em que a autora faz uma avaliação qualitativa da ocupação, embora tenha reconhecido, ao longo de todo o texto, o proeminente papel da “devastação secular da floresta" (SANTOS, 1999, p. 121) que transformou profundamente as paisagens originais.

Ao longo do texto, também se percebe preocupações econômicas que extravasam o limite acadêmico e as aproximam daquelas presentes no serviço de reconhecimento territorial voltado à planificação estatal constante nos materiais publicados pela RBG.

\footnotetext{
${ }^{154}$ A autora descreve a paisagem regional segundo a compartimentação da paisagem identificável no índice de seu trabalho. Cf. ANEXO D, especificamente Capítulo 4, "As Paisagens".
} 


\subsection{GEOGRAFIA À SERVIÇO DO GRANDE EMPREENDIMENTO}

Uma ciência despropositada, inocente quanto à finalidade de suas práticas definitivamente não é o caso na quase totalidade dos materiais consultados. Se a ciência geográfica brasileira testemunhou o surgimento de trabalhos mnemônicos e insípidos, este testemunho não emergiu dos centros de pesquisa em Geografia que surgiram no Brasil a partir da década de 1930, cada um engajado ao seu respectivo "projeto nacional".

Em relação à produção acadêmica, de certa forma, todas as teses consultadas fornecem alguma sugestão do ponto de vista do planejamento territorial. A sutileza de algumas considerações nos faz crer no esforço de manutenção do teor acadêmico da redação embora, quase sempre, a ligação histórica da disciplina com questões do âmbito territorial se imponha. A este respeito, não se pode perder de vista o próprio posicionamento de Pierre Monbeig:

Tal como o conhecimento geográfico é indispensável à formação do homem moderno, a pesquisa geográfica é indispensável à boa gestão de um grande empreendimento, à boa administração de um Estado moderno. É tal a multiplicidade dos problemas que surgem no quadro do meio atual, que a contribuição de cada técnico se arrisca a cair numa especialização estreita, às vezes esterilizante. Pela largueza de seus pontos de vista, o geógrafo completa os técnicos. Os problemas que ele pode ajudar a resolver mais se evidenciam num país como o Brasil, onde há tantas áreas para organizar, onde tantas possibilidades restam a explorar, onde tanto dinamismo se gasta em tantas direções contraditórias. (MONBEIG, 1957, p. 24-25)

Além do caráter utilitário assumido pela Geografia junto à planificação estatal, vale observar a leitura da pobreza e da miséria principalmente entre os tipos sociais tradicionais das regiões analisadas, que permanecem à margem do desenvolvimento econômico experimentado nas zonas mais dinâmicas do país. A planificação econômica seria um meio para se contornar esse quadro. Assim, afirma Carvalho:

Tal sistema de pesca mantém o pescador numa situação muito precária. Falta de recursos para fazer estoque de sal, vê-se ele, às vezes, forçado a vender o peixe por pouco mais de nada ou a deixa-lo estragar-se. [...] Os benefícios resultantes da organização da pesca ainda estão longe de ter alcançado o pescador, talvez porque, precisando de tudo, seja mais difícil dar-lhe alguma coisa. (CARVALHO, 1944, p. 111)

Após dedicar um capítulo às atividades econômicas dos sitiantes, permeado de considerações críticas no âmbito econômico, Müller conclui:

Evitando qualquer senso de valor, cremos poder dizer, objetivamente, que o sitiante paulista é melhor material humano do que geralmente se pensa. Vem ele demonstrando capacidade de desenvolver diferentes tipos de atividade, de poder tornar-se parcela ponderável da economia geral. Se não o faz mais e melhor, é frequentemente, mais por falta de orientação e de apoio, que por rotina ou indiferença. (MÜLLER, 1946, p. 73) 
Renato da Silveira Mendes, após comentar as dispendiosas obras de saneamento e colonização oficial da Baixada Fluminense promovidas pelo Governo Federal a partir dos anos 1930, conclui:

[Ademais, para] que o homem possa tirar proveito dessas terras e aí viver saudavelmente impõe-se a criação de uma nova paisagem cultural, onde os elementos naturais adversos sejam dominados. Entretanto, si houver um abandono temporário da conservação das obras de saneamento, a natureza voltará a se impor e toda a conquista humana ruirá fragorosamente. Os exemplos da história da região comprovam perfeitamente tal assertiva e não podem ser esquecidos. (MENDES, 1948, p. 117-8)

Araújo Filho, com sua forma peculiarmente superficial ou classista, também faz numerosas sugestões no âmbito econômico. O item cinco e final da conclusão de sua tese é explícito quanto à sua preocupação:

Sob a direção dos poderes públicos se possível, mas obrigatoriamente com sua aquiescência e ajuda, deve-se o quanto antes, iniciar um trabalho de recuperação (de verdadeira ocupação, seria o termo) do litoral através de uma reação enérgica onde se encadeassem todos os setores de uma racionalização do trabalho; da construção de vias de comunicações ao saneamento; da instrução e alimentação do caiçara ao seu preparo técnico para a pesca ou para a lavoura; da ocupação de fato da terra, com seu aproveitamento intensivo, a uma produção organizada e de interesse comercial. (ARAÚJO FILHO, 1950, p. 117)

Enfim, se as teses se prendem excessivamente ao aspecto formal do método regional em voga na época ou se procuram áreas-objeto em que o método se aplique, relegando as demais áreas - em geral urbanas - ao abandono analítico, o fato é que o rigor histórico-descritivo de paisagens regionais presente nestas primeiras teses é suficiente, ao menos, para dar sugestões seguras no âmbito da planificação econômica. A pergunta que fica, sem dúvida, é a mesma voltada aos materiais publicados na RBG, com o adendo de que no caso das teses, $\mathrm{o}$ comprometimento com as demandas estatais não era sua razão fundamental: estes materiais ofereceram, de fato, o que setores técnicos estatais voltados ao planejamento territorial poderiam esperar deles? ${ }^{155}$

Se havia uma motivação econômica por trás do desenvolvimento da Geografia moderna no Brasil - e aqui nos referimos à fundação do CNG e à inauguração dos cursos universitários de Geografia em São Paulo e Rio de Janeiro - é possível que a ciência geográfica tenha se beneficiado tanto ou mais no âmbito acadêmico do que o Estado no âmbito prático.

155 Pode-se, mesmo, questionar se o Estado nacional brasileiro possuiu um aparelho de planejamento efetivamente comprometido com o desenvolvimento econômico regional brasileiro, uma vez que no plano executivo os projetos parecem estar distantes das sugestões acadêmicas. 


\title{
CONSIDERAÇÕES FINAIS
}

\author{
"You can't just connect the dots; as you're creating your forms, \\ you need to discover what the forms are capable of." John Corigliano ${ }^{156}$
}

O conhecimento geográfico está intimamente relacionado à dimensão formal das coisas distribuídas na superfície terrestre em função do processo de apropriação da natureza pelos grupos humanos. Jean Brunhes já nos primeiros parágrafos de sua Geografia Humana (1962) delimita o escopo de estudo da Geografia Humana aos fatos geográficos, fenômenos de expressão material, passíveis de observação, relacionados à atividade humana e às condições telúricas. Também Milton Santos, em sua extraordinária Por uma Geografia Nova (2004), justapõe-se à tradição ao afirmar que as "formas espaciais são resistentes à mudança social e uma das razões disso está em que elas são também ou antes de tudo matéria." (SANTOS, 2004, p. 187, grifo nosso.)

Coleta e classificação de informações sobre as mais diversas partes do mundo, sob o paradigma da exploração territorial, foi o selo da legitimidade da atividade geográfica que remontava ao período clássico. Expedições financiadas por diversos agentes do capitalismo comercial mantiveram em alta o prestígio desse paradigma até a $2^{\mathrm{a}}$ Guerra Mundial, enquanto o conhecimento territorial e a confecção cartográfica eram de interesse estratégico para as companhias comerciais e para o setor militar. (JOHNSTON, 1986)

O florescimento da moderna Geografia no Brasil respaldou-se na experiência e no aporte teórico-metodológico trazidos na bagagem das missões estrangeiras e aos geógrafos e praticantes da Geografia coube um reclame de autoridade sobre a tradição por meio da aprovação de leis e decretos junto ao poder público, quando este demonstrou-se a par da necessidade de "redescobrir" o país.

Em que pese o amplo serviço cartográfico assumido pelos primeiros colaboradores do Conselho Nacional de Geografia e do próprio raciocínio cartográfico comum aos inúmeros trabalhos descritivos executados pelos pioneiros da Geografia moderna no Brasil, esta primeira geração de geógrafos não chegou a apreender a lógica capitalista subjacente ao sentido das localizações no processo de apropriação do território nacional levado a cabo pelo Estado e por agentes privados. Com efeito, deve-se atentar para o propósito do conhecimento

${ }^{156}$ MAY, Thomas. Bates: Liquid Interface for Orchestra and Electronica. (Program Notes.) Disponível em: $<$ https://www.sfsymphony.org/Watch-Listen-Learn/Read-Program-Notes/Program-Notes/BATES-\%C2\%A0Liqu id-Interface-for-Orchestra-and-Electron.aspx>. Acesso em: 20 jul. 2016. 
geográfico no Brasil até, pelo menos, o início da década de 1960, já que a estruturação das condições concretas para sua reprodução perpassava seu engajamento junto aos propósitos dominantes. Para ser socialmente relevante, conforme ressalta Lamego (2014), a ciência geográfica precisava contribuir com o conhecimento científico em prol do desenvolvimento social e econômico do país.

Embora tal constatação não isente a Geografia de sua responsabilidade no que concerne à relevância social que se espera da ciência contemporânea, a preservação do contexto de reprodução do conhecimento possibilita a compreensão ou mesmo recuperação dos alicerces do pensamento. Milton Santos atesta logo na introdução de Por uma Geografia Nova a inexistência de um sistema lógico de estruturação do pensamento geográfico:

Se a geografia não foi capaz de ultrapassar esta deficiência, é porque esteve sempre
muito mais preocupada com uma discussão narcísea em torno da geografia como
disciplina ao invés de preocupar- se com a geografia como objeto. Sempre, e ainda
hoje, se discute muito mais sobre a geografia do que sobre o espaço, que é o objeto
da ciência geográfica. (SANTOS, 2004 [1978], p. 18, grifos do autor.)

Uma crítica ao pensamento geográfico dos pioneiros que desconsidere o contexto do pensamento e que ignore o objeto sobre o qual se detinham teria, ao menos, o poder de dificultar ainda mais o debate em torno do modo de pensar da Geografia. No mesmo sentido, não se pode confundir o IBGE, no plano institucional, com o pensamento geográfico que nele se desenvolveu, repleto contradições e idiossincrasias. Esta confusão aparenta ainda ser recorrente e mesmo injusta com os profissionais que fomentaram o discurso geográfico no seio do Instituto, inclusive porque a prática geográfica junto às Universidades também se ligava às respectivas aspirações de Estado.

Já na definição do escopo da Geografia Humana de Jean Brunhes observa-se certo antropocentrismo no tratamento privilegiado dos fatos geográficos de que participa a atividade humana. Hartshorne (1978, p. 48) aponta que "quaisquer que sejam os aspectos da superfície da terra que o geógrafo analise, inevitavelmente há de meditar sobre eles em função da sua significância para o homem.” O que os geógrafos elegem como significante de ser observado e analisado sob o ângulo da Geografia está muito relacionado a uma determinada concepção de mundo. Mas, ainda que se considere a subjetividade de julgamento do pesquisador na eleição dos elementos mais significativos no estudo de um determinado fenômeno, a produção geográfica dos pioneiros, fruto de ação e pensamento conjugados, obedecia a um propósito. O contexto histórico-social do funcionalismo brasileiro a partir dos anos 1930 estava permeado de boa-fé no avanço das forças produtivas em território nacional, o que justificava a priori o olhar engajado do geógrafo junto ao Estado, sobretudo, se se 
considerar, conforme o fez Getúlio Vargas, "as vantagens de caráter nacional da atividade de um Conselho Brasileiro de Geografia articulado com a Administração Federal na importante missão de coordenação da Geografia do Brasil”. (BRASIL, 1937) ${ }^{157}$

Entre economistas, engenheiros, historiadores e cientistas sociais à serviço da "administração, da guerra e do capital" situavam-se os geógrafos e, pelo menos entre estes, a boa-fé no plano da prática profissional vinha acompanhada, de certo modo, de uma cômoda indiferença no plano teórico, ainda que não abrangente a todos os geógrafos. O saber geográfico praticado no seio das modernas instituições geográficas brasileiras era a síntese do perfil de geógrafo detentor de uma prática oficiosa que remetia à Antiguidade e que, a partir do Iluminismo, configura-se cartográfica e codificadora ideológica do imperialismo europeu. "E o geógrafo deve ser o especialista da elaboração de mapas que ao tempo que inscrevam como natural a cosmologia europeia, apresentem a sua racionalidade como o destino civilizatório de todos os povos." (MOREIRA, 2010, p. 15) O período subsequente de mundialização da indústria e dos territórios planejados e ordenados pela intervenção do Estado confere à Geografia, por meio do planejamento estatal, "um dos momentos de ápice de sua história." (MOREIRA, 2010, p. 15-16)

Esta cômoda indiferença no plano teórico, que garantiu aos geógrafos a chancela da utilidade e a possibilidade de levar adiante a prática de seu saber, é reflexo da forte união da Geografia com o Estado e que atrelou o destino de um ao outro. Da indiferença emergiu uma dissonância entre o pensamento geográfico e a leitura geográfica de mundo, descompasso este que - agora o percebemos - arrebata a ciência geográfica contemporânea, mercê da desterritorialização do capital e da reforma do Estado que pôs fim à era do planejamento territorial - e dá sentido à presente dissertação.

Isto posto, pode-se a posteriori entender a presente dissertação como um exercício de comprovação, em termos materiais, da crítica da contemporânea incapacidade da ciência geográfica "de ler e explicar o mundo a partir da leitura do significado das imagens presentes na paisagem." (MoREIRA, 2010, p. 22) Tal crítica o fizeram intelectuais de expressão como Ruy Moreira e Milton Santos e suas contribuições, arriscamo-nos a afirmar, parecem ainda não terem sido suficientemente assimiladas.

Tomando-se como pontos referenciais a percepção, entre os geógrafos, da crise socioespacial, com destaque aos debates acerca do subdesenvolvimento, a partir dos anos 1960, e a insuficiência dos móveis analíticos da Geografia, a partir dos anos 1970, dos quais o

157 BRASIL. Decreto n. 1.527, de 24 mar. 1937. Disponível em: <http://www2.camara.leg.br/legin/fed/decret/1930 -1939/decreto-1527-24-marco-1937-449842-republicacao-74463-pe.html> Acesso em 13 jan. 2016. 
movimento de renovação crítica da Geografia é tributária, e associando-se a eles nossa experiência acumulada com a Geografia a partir de 2006, da qual o processo de produção da presente dissertação é parte importante, poderíamos afirmar que o entendimento acerca do modo de pensar geograficamente o mundo - que envolve necessariamente reflexão quanto a objeto, método e instrumentos de análise - tornou-se mais intrincado. Isto porque não parece haver um entendimento satisfatório em relação à importância da forma de pensamento da Geografia anterior às fases citadas, bem como não parece haver nitidez quanto a um projeto para a Geografia que se almeja ou, em outras palavras, pratica-se uma Geografia fragmentada, ao sabor de interesses pessoais e da disciplinarização irrefreada do saber e sem reflexões quanto à forma de ser pensar geograficamente o mundo.

Talvez, uma das maneiras de entendimento do já esgotado adágio "crise da Geografia” é o impasse que emerge entre a desatenção quanto à forma de pensar dessa ciência, comum até o período anterior à renovação do saber geográfico, e a fragmentação extrema das práticas geográficas do presente. Muitas dessas formas contemporâneas de se praticar Geografia são fruto do período de renovação crítica, a partir dos anos 1960, para o enfrentamento do qual sentimo-nos, agora, mais qualificado.

Todo nosso esforço - malgrado os cortes e as escolhas exigidas durante o processo de pesquisa -, voltado para o passado, para o período pré-crítico da Geografia, orientou-se no sentido de não construirmos afirmações sem uma correspondente coletânea de comprovações. Se há um volume elevado de críticas endereçadas à chamada Geografia tradicional, há um volume ainda maior de desentendimentos quanto à sua natureza, fato comum entre os estudantes universitários do Departamento de Geografia da USP, convidados à crítica anterior à compreensão do objeto a ser criticado.

A disjunção entre forma e conteúdo ou o descompasso entre a tradição e seu sentido no mundo contemporâneo parecem ser, contudo, desafios que se impõem não apenas ao saber geográfico. Se nos é permitido uma comparação pouco ortodoxa, em artigo dedicado à obra ainda recente do compositor contemporâneo Mason Bates - em evidência na atualidade por aproximar com alguma destreza o concerto sinfônico aos recursos eletrônicos -, deparamonos com o conselho de um de seus principais mentores, o Prof. John Corigliano, da Juilliard School, destacado na epígrafe, segundo o qual você não pode ligar os pontos; ao se criar formas, é necessário se descobrir o que essas formas são capazes de fazer. 
Sobejamente edificada sobre os ditames da tradição musical ocidental, nossa impressão ${ }^{158}$ é a de que a música erudita na atualidade carece de um significado maior do que uns momentos de aplausos maquinais. Com efeito, o analfabetismo musical de um amplo público neófito em música erudita, ainda mais em um país de capitalismo periférico como o Brasil, torna o mais trilhado caminho sinfônico terreno inexplorado, com o agravante de que o contexto atual raramente faz qualquer alusão àqueles em que as mais famosas obras foram compostas. Até mesmo os instrumentos musicais e as salas de concerto transformaram-se profundamente. Beethoven com sua Sinfonia n. 3, Eroica, por exemplo, dedicada inicialmente a ninguém menos que Napoleão Bonaparte, buscou revolucionar brincando com expectativas que já não temos e desmantelando expectativas que já não nos orientam:

Em decorrência, a Eroica, que surgiu com tanta energia que alguns dos primeiros
ouvintes pensaram que o compositor estivesse louco, soa para nós como sabedoria
bem estabelecida. Seus contemporâneos jamais haviam vivenciado aqueles sons
selvagens, altos e agressivos, fora de uma situação de combate. Nossos ouvidos
estão afinados com uma paisagem sonora mais violenta: as construções em torno do
Lincoln Center são muito mais ásperas do que quer que aconteça dentro da sala.
(DAVIDSON, 2012, p. 6)

Nem por isso, a Eroica de Beethoven deixou, na atualidade, de transmitir uma mensagem que mereça ser ouvida. Entre o respeito à tradição e a busca por diálogo junto ao fragmentado público contemporâneo, a música erudita tem que procurar uma maneira de transmitir uma mensagem merecedora de aplausos ou vaias autênticas.

Algo semelhante parece ocorrer à Geografia e dar razão a críticas como a de Yves Lacoste (2012). A feição geográfica do mundo contemporâneo impõe a todos o desafio de relações simultâneas, mediatas e multi-escalares capazes de alterar rapidamente a maneira como nos relacionamos com a geografia dos lugares. Uma parte significativa das tensões, medos e angústias típicas de nosso tempo parece emergir da relação de estranhamento que se estabelece entre as formas geográficas e os indivíduos, para o enfrentamento da qual o discurso geográfico pouco tem contribuído, especialmente no âmbito escolar, instituição a princípio privilegiada de preparação dos indivíduos para o mundo. O que parece é que, a despeito da preparação escolar em Geografia, os jovens adultos são lançados ao mundo assim como os neófitos em música erudita às salas de concerto. E, frente ao já exposto, não poderíamos atribuir este problema apenas às deficiências do universo escolar.

Esta pesquisa debruçou-se, assim, sobre o período de apogeu de uma determinada forma de se praticar Geografia, ao longo do qual havia uma certeza implícita do conteúdo que se

\footnotetext{
${ }^{158}$ Sou assinante do programa sinfônico da Orquestra Sinfônica do Estado de São Paulo desde 2008 e, de lá para cá, já assisti a mais de cem apresentações, não apenas da Osesp, em diversas circunstâncias.
} 
estudava, embora marcada por uma ambiguidade entre o pragmatismo da prática e o academicismo na apresentação. Os objetivos e aspirações dos pioneiros da Geografia revelam o que pouco se perguntava no plano teórico-metodológico quanto ao conteúdo da reflexão geográfica. A apropriação do território nacional pelo Estado brasileiro, dentro do programa getulista de governo, levou os geógrafos no CNG a pensarem o território nacional, em sua unidade, ao passo que a comunidade de geógrafos do Departamento de Geografia da USP voltou-se ao estado de São Paulo, em especial aos locais de maior dinamismo econômico, o porto de Santos e as zonas pioneiras do interior e do litoral. Seguindo os princípios da Geografia regional francesa, focalizava-se relações de longa duração ambientadas no meio rural, onde a relação sociedade-natureza era "mais evidente", embora a forte plasticidade das relações socioespaciais estabelecidas não-raro gerasse perplexidade junto aos pesquisadores. Assim, complementam-se temas tais como desenvolvimento agrícola de dezenas de diferentes produtos, exploração racional do solo e análise pedológica de zonas potenciais, levantamento mineralógico e fitogeográfico, desenvolvimento de meios de circulação e estudos dedicados a planos de colonização ou aos seus impactos, bem como nova divisão do território nacional, acesso e desenvolvimento de zonas fronteiriças e transferência da capital nacional. São trabalhos que nada tem de abstrato e que nem de longe refletem respostas pouco claras quanto ao objeto da ciência geográfica. Ademais, a relevância social desta ciência adquire outra qualidade quando se considera o contexto histórico dentro do qual o propósito do saber ganhava sentido.

Neste percurso trilhado pelos fundamentos do saber geográfico, algumas escolhas foram necessárias, quanto outros caminhos foram identificados. Reflexo de nossa juventude intelectual, tomamos cerca de um ano na tentativa de compreender o contexto histórico, político e social do reduzido círculo intelectual brasileiro e de trânsitos como o de Getúlio Vargas por tertúlias geográficas, impensáveis nos dias de hoje.

Uma historiografia das instituições geográficas brasileiras é tema ainda pouco explorado, tão fértil quanto trabalhoso devido à ainda ausência de fontes secundárias em quantidade. A relação acadêmica e política (inclusas as relações de poder) das instituições geográficas, sobre as quais pretendíamos ter versado em maior profundidade, é caminho também a ser largamente explorado. Numerosos trabalhos nesse sentido tem surgido, todos muito recentes, praticamente simultâneos à presente redação.

A Revista Brasileira de Geografia, em sua unidade, revelou-se um extraordinário universo a ser explorado e lamentamos não termos percebido com antecedência a possibilidade de nos debruçarmos apenas sobre ela. Ainda que se afirme a disparidade de 
temas cobertos pela ciência geográfica, há uma rica complementaridade temática entre os materiais publicados na Revista, que se torna ainda mais evidente se se considera um conjunto de leis e decretos por meio dos quais a comunidade geográfica garantiu as condições concretas par sua reprodução. Devemos ao Prof. Dr. Jorge Luiz Barcellos da Silva, membro da Banca de Qualificação, o questionamento acerca do princípio lógico que presidiria a escolha dos materiais a serem analisados ante o amplo universo.

Com efeito, identificado um critério para escolha dos materiais, pretendíamos nos debruçar sobre os materiais publicados sob os temas GEOGRAFIA REGIONAL, HPG / TM, GEOMORFOLOGIA, GEOGRAFIA ECONÔMICA, CARTOGRAFIA, GEOGRAFIA POLÍTICA, COLONIZAÇÃO, PEDOLOGIA e GEOGRAFIA DOS TRANSPORTES, conforme se atesta na TABELA 1 e no GRÁFICO 1 (cf. item 2.3). Os trabalhos sob a entrada GEOGRAFIA REGIONAL, embora numerosos, expressaram mais um princípio de método do que um tipo específico de estudo. Sua análise requereria um estudo à parte. Em resumo, restringimo-nos aos estudos GEOGRAFIA ECONÔMICA, CARTOGRAFIA, GEOGRAFIA POLÍTICA e COLONIZAÇÃO, embora, como já o dissemos, os temas se entrecruzam permanentemente. Diversos materiais consultados tiveram, devido aos limites da pesquisa, de ser desconsiderados.

Ademais, grande quantidade de materiais publicados na esfera do Departamento de Geografia da USP poderiam ter sido consultados para uma análise comparativa com as publicações financiadas pelo IBGE. São fontes primárias ou publicações pioneiras, como a revista Geografia, ainda amplamente desconsiderados e que despertaram nosso interesse.

A própria História do Departamento de Geografia da USP demonstrou-se, surpreendentemente, um trabalho por ser feito. Professores representantes do saber clássico da Geografia merecem ser ouvidos, enquanto trabalhos clássicos dos pioneiros da Geografia acadêmica do Brasil aguardam melhor tratamento.

Por fim, todo nosso trabalho teria se enriquecido extraordinariamente se tivéssemos explorado as correntes de pensamento que dão forma ao conteúdo explorado pelos geógrafos que exerceram sua prática nos tempos áureos da Geografia. Mas este passo se situa além de nossas pretensões, enfim, modestas.

Ao que cabe a uma reflexão à luz do processo de pesquisa percorrido, assumimos a possibilidade de se extrair considerações mais concisas acerca dos fundamentos do saber geográfico, que pavimentariam reflexões quanto à possibilidade de crítica do próprio saber científico na compreensão do mundo moderno. Muitas dessas considerações, de todo modo, não seriam novidade e já ocupam expressivas páginas de importantes nomes da literatura, para as quais agora nos sentimos mais habilitados a enfrentar. 


\section{REFERÊNCIAS BIBLIOGRÁFICAS}

Abrantes, Vera L. C. Era preciso redescobrir o Brasil. Terra Brasilis Online. (Nova Série), v. 3, 2014. Disponível em: <http://terrabrasilis.revues.org/982>. Acesso em: 26 nov. 2014.

ABReu, Silvio Fróis. Alguns desenhos de Guaíra Heberle. Revista Brasileira de Geografia, v. 4, n. 4, 1942, p. 843-848.

ABREU, Silvio Fróis. II Reunião Pan-americana de Consulta sobre Geografia e Cartografia. Boletim Geográfico, v. 1, n. 9, 1943, p. 3-4. (Editorial.)

Abreu, Silvio Fróis. O crescimento do Patrimônio Mineral do Brasil no último decênio. Revista Brasileira de Geografia, v. 3, n. 4, 1941, p. 771-784.

AB-SÁBER, Aziz Nacib. 25 anos de Geografia em São Paulo (1935-1959). Boletim Paulista de Geografia. São Paulo: AGB-SP, 2005, p. 77-92.

AB-SÁBer, Aziz Nacib. Entrevista. Boletim Paulista de Geografia. São Paulo: AGB-SP, 2005, p. 9-36. Entrevista concedida a Laís Mourão e Alexandre Nascimento e Silva.

AB-SÁBER, Aziz Nacib. Pierre Monbeig: a herança intelectual de um geógrafo. Estudos Avançados, v. 8, n. 22, 1994, p. 221-232.

ADAS, Sérgio. O campo do geógrafo: colonização e agricultura na obra de Orlando Valverde. São Paulo, 2006, p. 40-60. Tese (Doutorado) - Faculdade de Filosofia, Letras e Ciências Humanas, Universidade de São Paulo.

Aguiar, Comte. Brás Dias de. Geografia amazônica: nas fronteiras do Norte. Revista Brasileira de Geografia, v. 6, n. 3, 1944, p. 327-348.

Alentejano, Paulo Roberto R. AGB-RIO: 68 anos de história. Terra Livre, ano 20, v. 1, n. 22,2004 , p. 145-152.

ALMEIDA, Roberto Schmidt de. A estruturação da tecnoburocracia do planejamento territorial no Brasil. Terra Brasilis Online, v. 4 5, 2003. Disponível em < http://terrabrasilis.revues.org/356>. Acesso em: 26 nov. 2014.

AlmEIDA, Roberto Schmidt de. A Geografia e os geógrafos do IBGE no período 1938-1998. Rio de Janeiro, 2000, 634p. Tese (Doutorado) - Instituto de Geociências, Universidade Federal do Rio de Janeiro.

AlmeIDA, Roberto Schmidt de. O IBGE e a evolução da idéia de desenvolvimento no Brasil. Revista Geográfica, 1994, 22p.

Alonso, Delnida Martinez. Aspectos geográficos da cultura fumageira no Estado do Rio Grande do Sul, Brasil. Revista Brasileira de Geografia, v. 20, n. 3, 1958, p. 295-313. 
ANDRADE, Manuel C. de. O pensamento geográfico e a realidade brasileira. Boletim Paulista de Geografia, São Paulo: AGB-SP, n. 54, 1977, pp. 5-28.

Andrade, Manuel C. de. Pierre Monbeig e o pensamento Geográfico no Brasil. Boletim Paulista de Geografia, São Paulo: AGB-SP, n. 72, 1994, p. 63-82.

ARANHA, Patricia Marinho. O IBGE e a consolidação da geografia universitária brasileira. Terra Brasilis Online. (Nova Série), v. 3, 2014. Disponível em: $<\mathrm{http}$ ://terrabrasilis.revues.org/971>. Acesso em: 26 nov. 2014.

ARaúJo Filho, José Ribeiro de. A baixada do Rio Itanhaém. Estudo de Geografia Regional. São Paulo, 1950, 123p. Tese (Doutorado) - Faculdade de Filosofia, Ciências e Letras, Universidade de São Paulo.

AzEvedo, Aroldo de. Goiânia. Uma cidade "criada". Revista Brasileira de Geografia, v. 3, n. 1, 1941, p. 3-19.

BACKHEUSER, Everardo. Fronteiras da Geologia e da Geografia e a unidade desta ciência. Revista Brasileira de Geografia, v. 3, n. 3, 1941, p. 637-646. (Comentários.)

BACKHEUSER, Everardo. Geopolítica e geografia política. Revista Brasileira de Geografia, v. 4, n. 1, 1942, p. 21-38.

BECKER, Bertha. A Geografia e o resgate da Geopolítica. Revista Brasileira de Geografia, ano 50, n. especial t.2, 1988, pp. 99-125.

BIANCHI, Ferdinando. Considerações sobre o levantamento de áreas extensas pela fotogrametria aérea. Revista Brasileira de Geografia, v. 4, n. 4, 1942, p. 771-790.

BOMBARDI, Larissa Mies. Contribuição à historiografia da geografia agrária na Universidade de São Paulo. Agrária, n. 8, p. 99-121, 2008.

BomfIM, Paulo Roberto de Albuquerque. Conceitos e significados do planejamento na geografia brasileira e o IBGE. Terra Brasilis Online (Nova Série), v. 5, 2015. 16p. Disponível em: <http://terrabrasilis.revues.org/1494>. Acesso em: 20 jul. 2016.

Bomfim, Paulo Roberto de Albuquerque. Teoria e prática do planejamento regional no IBGE na década de 1960. Terra Brasilis Online (Nova Série), v. 3, 2014. 34p. Disponível em: $<$ http://terrabrasilis.revues.org/1003>. Acesso em: 24 nov. 2014.

BONDAR, Gregório. As possibilidades econômicas do centro do Estado da Bahia.. Revista Brasileira de Geografia, v. 12, n. 4, 1950, p. 614-620.

Botelho, Carlos de Castro. Aspectos geográficos da zona cacaueira da Bahia. Revista Brasileira de Geografia, v. 16, n. 2, 1954, p. 161-212.

CAMARgo, Alexandre de P. R. A Revista Brasileira de Geografia e a organização do campo geográfico no Brasil (1939-1980). Revista Brasileira de História da Ciência, Rio de Janeiro, v. 2, n. 1, jan-jun 2009, p. 23-39. 
Campos, Rui Ribeiro de. A dimensão populacional na obra de Josué de Castro. Rio Claro, 2004, p. 6-144. Tese (Doutorado) - Instituto de Geociências e Ciências Exatas, Universidade Estadual Paulista.

CAPEL, Horacio. Filosofia y ciencia en la geografía contemporánea. Barcelona: Barcanova, 1981.

CARLI, Gileno Dé. Civilização do açúcar no Brasil. Revista Brasileira de Geografia, v. 2, n. 3, 1941, p. 349-371.

CARlos, Ana Fani Alessandri. A Geografia Brasileira Hoje: Algumas Reflexões. Terra Livre, ano 18 , v. 1 , n. 18,2002 , p. 161-178.

Carvalho, C. M. Delgado de. Geografia das fronteiras. Revista Brasileira de Geografia, v. 1, n. 3, 1939, p. 95-110. (Comentários.) [Resenha da obra homônima sob autoria de Jacques ANCEL.]

CARvalho, Maria Conceição Vicente de. Santos e a geografia humana do litoral paulista. São Paulo, 1944, 219p. Tese (Doutorado) - Faculdade de Filosofia, Ciências e Letras, Universidade de São Paulo.

CAstro, Christovam Leite de. A mudança da capital do País à luz da ciência geográfica. Notas taquigráficas. Revista Brasileira de Geografia, v. 9, n. 2, 1947, p. 279-285. (Comentários.)

CAstro, Christovam Leite de. A mudança da capital do País. Revista Brasileira de Geografia, v. 10, n. 3, 1948, p. 449-451. (Comentários.)

CAstro, Christovam Leite de. A transferência da capital do País para o Planalto Central. Revista Brasileira de Geografia, v. 8, n. 4, 1946, p. 567-572. (Comentários.)

CAstro, Christovam Leite de. O Serviço de Geografia e Estatística Fisiográfica. Revista Brasileira de Estatística, v. 4, n. 14, 1943, p. 225-230.

CAstro, Christovam Leite de. Retôrno do Brasil ao seio do Instituto Pan-Americano de Geografia e História. Revista Brasileira de Geografia, v. 6, n. 2, 1944, pp. 295-298. (Noticiário.)

Claval, Paul. Evolución de la geografía humana. Barcelona: Oikos-tau, 1974, p. 1-142.

Conti, José Bueno. Geografia e Paisagem. Ciência e Natura, v. 36 Ed. Especial, 2014, p. 239-245.

CORREIA Filho, Virgílio. A geografia como fator das vitorias diplomáticas do Barão do Rio Branco. Revista Brasileira de Geografia, v. 7, n. 2, 1945, p. 261-302.

Costa, Wanderley Messias da. O Estado e as políticas territoriais no Brasil. 11.ed., São Paulo: Contexto, 2013 [1988]. (Repensando a Geografia) 
Dantas, Aldo. Monbeig e a noção de Complexo Geográfico. Confins Online, n. 9, 2009. 16p. Disponível em: <http://confins.revues.org/6091>. Acesso em: 14 abr. 2016.

DAVIDSON, Justin. Beethoven bomba! Revista Osesp, set./out. 2012, p. 5-7. ISSN 2238-0299

Deffontaines, P. Regiões e Paisagens do Estado de São Paulo. Boletim Geográfico, v. 2, n. 24, p. 1837-1850; v. 3, n. 25, p. 18-27, 1945. [Publicado originalmente nos Annales de Géographie, n. 253, jan. 1936. Trad. de Orlando Valverde.]

Deffontaines, Pierre. A Associação dos Geógrafos Brasileiros (Introdução). In: Custódio, Vanderli (Org.). Fundamentos teórico-metodológicos do ensino e da pesquisa em Geografia: textos selecionados das primeiras publicações da Associação dos Geógrafos Brasileiros (AGB) - GEOGRAFIA (1935-1936) e Boletim DA AGB (1941-1944). São Paulo: AGB, 2012, p. 11-12. [Originalmente publicado em GEOGRAFIA, publicação trimestral da AGB. São Paulo. Ano I, n.1, 1935. 114p.]

DefFontaines, Pierre. Geografia Humana do Brasil. Revista Brasileira de Geografia, Rio de Janeiro: IBGE, v.1, n.1, pp. 19-67; n.2, pp. 20-56; n.3, pp. 16-59, 1939.

DiAs, Catarina V. Aspectos geográficos do comercio da castanha no médio Tocantins. Revista Brasileira de Geografia, v. 21, n.4, 1959, p. 517-31.

DINIZ Filho, Luis Lopes. Território e destino nacional. As ideologias geográficas no Estado Novo (1937-1945). São Paulo, 2002 (v. revisada), 146p. Dissertação (Mestrado) - Faculdade de Filosofia, Letras e Ciências Humanas, Universidade de São Paulo.

DrAIBE, Sônia. Rumos e Metamorfoses: um estudo sobre a constituição do Estado e as alternativas da industrialização no. Brasil 1930- 1960. 2.ed., Rio de Janeiro: Paz e Terra, 2004, p. 9-124.

FAISSOL, Speridião. Planejamento e Geografia: exemplos da experiência brasileira. Revista Brasileira de Geografia, ano 50, n. especial t.2, 1988, pp. 85-98

FAusto, Boris. História do Brasil. 6.ed., São Paulo: Edusp, 1999, p. 243-394.

Ferreira, Alexandre M. de M. Pires. A criação da Faculdade de Filosofia, Ciências e Letras da USP - Um estudo sobre o início da formação de pesquisadores e professores de matemática e de física em São Paulo. São Paulo, 2009, 271p. Tese (Doutorado) - Pontifícia Universidade Católica de São Paulo.

Figueiredo, Ten. Cel. José de Lima. Fronteiras amazônicas. Revista Brasileira de Geografia, v. 4, n. 3, 1942, p. 501-544.

FranÇA, Ary. Entrevista. Boletim Paulista de Geografia. São Paulo: AGB-SP, 2005, p. 4556. Entrevista concedida a Laís Mourão e Amália Inês Geraiges de Lemos.

FreitAs, Mário Augusto Teixeira de. A redivisão política do Brasil. Revista Brasileira de Geografia, v. 3, n. 3, 1941, p. 533-554. 
Furtado, Celso. Formação Econômica do Brasil. 34.ed., São Paulo: Cia. das Letras, 2013 [1959].

GABAGLIA, João Capistrano Raja. Introdução à leitura de cartas geológicas. Revista Brasileira de Geografia, v. 9, n. 2, 1947, p. 288. (Comentários.)

Galvão, Roberto. Aspectos da economia da borracha no território do Acre. Revista Brasileira de Geografia, v. 17, n. 2, 1955, p. 153-174.

GEIGER, Pedro P. Industrialização e urbanização no Brasil, conhecimento e atuação da Geografia. Revista Brasileira de Geografia, ano 50, n. especial t.2, 1988, pp. 59-84.

GeIGer, Pedro P.; DAvidovich, Fany; et al. Estudos para a Geografia da Indústria no Brasil Sudeste. Revista Brasileira de Geografia, v.25, n. 2, 1963, p. 155-271.

GonÇALVES, Jayci de Mattos Madeira. IBGE: Um retrato histórico. Rio de Janeiro: IBGE/CDDI, 1995. 61p.

GuERRA, Antônio Teixeira. A Geografia aplicada na conservação dos recursos naturais básicos, tendo em vista o poder nacional e a segurança nacional. Revista Brasileira de Geografia, v. 28, n. 1, 1966, p. 57-60.

GuERRA, Antônio Teixeira. Alguns aspectos geográficos da cidade de Rio Branco e do núcleo colonial seringal empresa, Território do Acre. Revista Brasileira de Geografia, v. 13, n. 4, 1951, p. 545-576.

Guerra, Antônio Teixeira. Aspectos geográficos do Território Federal do Acre. Revista Brasileira de Geografia, v. 16, n. 2, 1954, p. 234-251. (Comentários.)

Guerra, Antônio Teixeira. Importância da Geografia no Poder Nacional. Revista Brasileira de Geografia, v. 25, n. 4, 1963, p. 485-492.

Guimarães, Fábio de Macedo Soares. Divisão regional do Brasil. Revista Brasileira de Geografia, v. 3, n. 2, 1941, p. 318-373.

Guimarães, Fábio de Macedo Soares. O Planalto Central e o problema da mudança da capital do Brasil. Revista Brasileira de Geografia, v. 11, n. 4, 1949, p. 471-542.

Hartshorne, R. Propósitos e natureza da geografia. São Paulo: Hucitec, 1978.

Heberle, Afonso de Guaíra. A Gruta de Maquiné e seus arredores. Revista Brasileira de Geografia, v. 3, n. 2, 1941, p. 555-588.

Publicações realizadas pela Redação do IBGE, sem autoria específica. Para facilitar a localização das referências, organizou-se as entradas por ordem cronológica:

IBGE (1939a). Histórico da criação do CNG. Revista Brasileira de Geografia, Rio de Janeiro: IBGE, v.1, n.1, p. 9-18, 1939a. 
IBGE (1939b). Mapas municipais. Revista Brasileira de Geografia, v. 1, n. 1, 1939b, p. 8094. (Comentários.)

IBGE (1939c). Instalação do Serviço de Coordenação Geográfica. Revista Brasileira de Geografia, v. 1, n. 2, 1939c, p. 112. (Noticiário.)

IBGE (1939d). Uma campanha de levantamento de coordenadas geográficas. Revista Brasileira de Geografia, v. 1, n. 3, 1939d, p. 130-132. (Noticiário.)

IBGE (1939e). Comissão de uniformização da cartografia brasileira. Revista Brasileira de Geografia, v. 1, n. 4, 1939e, p. 124-125. (Noticiário.)

IBGE (1939f). Decreto-Lei n. 782, de 13 out. 1938. Revista Brasileira de Geografia, v. 1, n. 4, 1939f, p. 141-142. (Relatórios, Resoluções e Leis.)

IBGE (1940a). Um inquérito de alta cultura geográfica. Revista Brasileira de Geografia, Rio de Janeiro: IBGE, v. 2, n. 1, 1940a, p. 97-99. (Noticiário.)

IBGE (1940b). Exposição de mapas municipais. Revista Brasileira de Geografia, v. 2, n. 2, 1940b, p. 248-9. (Comentários.)

IBGE (1940c). Campanha de coordenadas geográficas. Revista Brasileira de Geografia, v. 2, n. 2, 1940c, p. 268-269. (Noticiário.)

IBGE (1942). Carta geográfica do Brasil ao milionésimo. Revista Brasileira de Geografia, v. 4, n. 2, 1942, p. 413-418. (Noticiário.)

IBGE (1943a). Resolução n. 18, de 30 dez. 1936, da Assembleia Geral do Conselho Nacional de Estatística. Boletim Geográfico, v. 1, n. 7, 1943, p. 212-213. (Leis e Resoluções.)

IBGE (1943b). Resolução n. 28, de 19 jul. 1938, da Assembleia Geral do Conselho Nacional de Geografia. Boletim Geográfico, v. 1, n. 7, 1943, p. 215-217. (Leis e Resoluções.)

IBGE (1944a). Decreto-Lei 6828, de 25 de agosto de 1944. Boletim Geográfico, v. 2, n. 17, 1944a, p. 782. (Leis e Resoluções.)

IBGE (1944b). Resolução n. 127, de 9 jul. 1942, da Assembleia Geral do Conselho Nacional de Geografia. Boletim Geográfico, v. 2, n. 18, 1944b, p. 968-969. (Leis e Resoluções.)

IBGE (1944c). As resoluções da II Reunião Pan-americana de Consulta sobre Geografia e Cartografia. Revista Brasileira de Geografia, v. 6, n. 3, 1944c, p. 375-379. (Comentários.)

IBGE (1944d). II Reunião Pan-americana de Consulta sobre Geografia e Cartografia. Revista Brasileira de Geografia, v. 6, n. 3, 1944d, p. 404-429. (Noticiário.)

IBGE (1945a). II Reunião Pan-americana de Consulta sobre Geografia e Cartografia. Boletim Geográfico, v. 3, n. 31, 1945a, p. 943-946. (Resenhas e Opiniões.)

IBGE (1945b). Primeiro centenário do nascimento do Barão do Rio Branco. Revista Brasileira de Geografia, v. 7, n. 2, 1945b, p. 322-327. (Noticiário.) 
IBGE (1946). Comissão técnica para o estudo da localização da nova Capital da União. Revista Brasileira de Geografia, v. 8, n. 4, 1946, p. 596-597. (Noticiário.)

IBGE (1947). Excursão ao Amapá: a pororoca. Revista Brasileira de Geografia, v. 9, n. 2, 1947, p. 289. (Comentários.)

IBGE (1954). Noticiário. Boletim Geográfico, v. 12, n. 119, 1954, p. 224-225. (Noticiário.)

IBGE (1955). XVIII Congresso Internacional de Geografia. Boletim Geográfico, v. 13, n. 128, 1955, p. 580-581. (Noticiário.)

INE. Convenção Nacional de Estatística. Rio de Janeiro: Ministério do Trabalho, Indústria e Commercio, Departamento de Estatística e Publicidade, 1936. 32p. Disponível em: $<$ http://biblioteca.ibge.gov.br/> Acesso em: 29 fev. 2016.

Jonhston, R. J. Geografia e geógrafos: a geografia humana anglo-americana desde 1945. São Paulo: DIFEL: 1986.

KISS, George. Geografia política na geopolítica; recentes tendências na Alemanha. Revista Brasileira de Geografia, v. 4, n. 4, 1942, p. 853-62. [Trad.: Germano JARDIM.]

LACoste, Yves. A geografia - Isso serve, em primeiro lugar, para fazer a guerra. 19.ed., Campinas: Papirus, 2012 [1976].

LAMEGO, Mariana. O IBGE e a geografia quantitativa brasileira. Terra Brasilis Online (Nova Série), v. 3, 2014. 27p. Disponível em: < http://terrabrasilis.revues.org/1015>. Acesso em: 13 nov. 2014.

LEAL, Fabiana M. Coordenadas geográficas: ser-no-mundo. Dissertação (Mestrado em Geografia) - São Paulo, DG-FFLCH-USP, 2010. 140p.

LENCIONI, S. Região e Geografia. São Paulo: EdUSP, 2009.

MACEDO, Maxsuel de Moura. As fases da Revista Brasileira da Geografia. In: III ENHPG e I ENGH, 2012, Rio de Janeiro. Anais do III Encontro Nacional de História do Pensamento Geográfico/I Encontro Nacional de Geografia Histórica, 2012.

MACHADO, Lia O. Origens do pensamento geográfico no Brasil: meio tropical, espaços vazios e a ideia de ordem (1870-1930). In: CASTRO, Iná E. de.; GomeS, Paulo Cesar da C.; CORRÊA, Roberto L. (Orgs.). Geografia: conceitos e temas. 2ed., Rio de Janeiro: Bertrand Brasil, 2000, pp. 309-52.

Machado, Mônica Sampaio. A construção da Geografia universitária no Rio de Janeiro. Rio de Janeiro: Apicuri, 2009.

MAMigOniAn, Armen. A AGB e a produção geográfica brasileira: avanços e recuos. Terra Livre, n. 8, 1991, p. 157-163. 
MARQues Neto, Roberto. Contribuição dos geógrafos franceses para o desenvolvimento da geografia física brasileira na primeira metade do século vinte: Emmanuel de Martonne e as superfícies de erosão. Revista de Geografia, Juiz de Fora: PPGEO-UFJF, v. 2, n. 1, p. 1-13, 2012. Disponível em: <http://www.ufjf.br/revistageografia/edicoes/edicoes-anteriores5/volume-2-n\%C2\%BA1-2012/>. Acesso em: 11 jun. 2015.

Martins, Elvio R.. Pensamento Geográfico é a Geografia em Pensamento. In: KatutA, Ângela M., et. al. (Orgs.). Geografia e Mídia Impressa. Londrina: Moriá, 2009, pp. 13-35.

Martonne, Emmanuel de. Problemas morfológicos do Brasil Tropical Atlântico. Revista Brasileira de Geografia, v. 5, n. 4, 1943, p. 559-572; v. 6, n. 2, p. 155-178.

Matos, Jaguaribe. de. Geratrizes memoráveis da Geografia do Brasil. Achêgas para um retrospecto cartográfico. Revista Brasileira de Geografia, Rio de Janeiro: IBGE, v.1, n.2, p. 3-19, 1939.

Melo, Mário Lacerda de. Aspectos da geografia do açúcar no Brasil. Revista Brasileira de Geografia, v. 16, n. 4, 1954, p. 467-492.

Mendes, Renato da Silveira. Paisagens culturais da Baixada Fluminense. São Paulo: FFCLUSP, 1950, 171p. (Boletim 110) [Apresentado originalmente como tese de doutoramento à cadeira de Geografia Humana da Faculdade de Filosofia, Ciências e Letras da Universidade de São Paulo, em 1948.

MiLliEt, S. Recenseamentos antigos. Revista Brasileira de Estatística, Rio de Janeiro: IBGE, v.16, n. 62, p. 144-150, 1955.

Monbeig, Pierre. Aspectos geográficos do Crescimento de São Paulo. Boletim Geográfico, v. 12, n. 119, 1954, p. 139-153. (Transcrições.)

Monbeig, Pierre. Complexidade em geografia humana. O Estado de S. Paulo, São Paulo, 9 abr. 1950, p. 4, 16 abr. 1950, p. 2.

Monbeig, Pierre. Estudos Geográficos. Boletim Geográfico, v. 1, n. 11, 1944, p. 7-11. (Comentários.)

Monbeig, Pierre. Papel e valor do ensino da Geografia e da sua pesquisa. In: Monbeig, Pierre. Novos estudos de geografia humana brasileira. São Paulo: Difusão Europeia do Livro, 1957, p. 5-25.

Monbeig, Pierre. Pesquisas geográficas. Boletim Geográfico, ano 3, v. 31, 1945, p. 915-9. (Comentário).

Monteiro, Carlos Augusto de F. A Geografia no Brasil (1934-1977): avaliação e tendências. São Paulo: Instituto de Geografia da Universidade de São Paulo, 1980.

Moraes, Antonio Carlos R. de. Notas sobre identidade nacional e institucionalização da Geografia no Brasil. Estudos Históricos, Rio de Janeiro, v.4, n. 8. 1991, p. 166-176. 
MORAES, Antonio Carlos Robert. Ideologias geográficas: espaço, cultura e política no Brasil. São Paulo: Annablume, 2005.

MOREIRA, Ruy. O pensamento geográfico brasileiro, vol. 1: as matrizes clássicas originárias. São Paulo: Contexto, 2008.

Moreira, Ruy. Pensar e ser em Geografia. São Paulo: Contexto, 2010.

MortarA, Giorgio. A população do Brasil. Revista Brasileira de Geografia, v. 7, n. 4, 1945, p. 631-650.

MüLLER, Nice Lecocq. Sítios e sitiantes no Estado de São Paulo. São Paulo: FFCL-USP, 1951, 217p. (Boletim 132) [Apresentado originalmente como tese de doutoramento à cadeira de Geografia Humana da Faculdade de Filosofia, Ciências e Letras da Universidade de São Paulo, em 1946.]

NogueIRA, Carlo Eugênio. A apropriação metodológica das frentes pioneiras na formação da Geografia Brasileira (1930-1950). Terra Brasilis Online (Nova Série), v. 5, 2015. 18p. Disponível em: <http://terrabrasilis.revues.org/1480>. Acesso em: 06 abr. 2016.

Oliveira, Francisco de. A economia da dependência imperfeita. 3.ed., Rio de Janeiro: Graal, 1980, 160p.

OliveIRA, Regina Celia Acioli. O Instituto Brasileiro de Geografia no Projeto Políticocultural do Estado Novo. São Paulo, 2005. 112p. Dissertação (Mestrado) - Centro de Pesquisa e Documentação de História Contemporânea do Brasil, Fundação Getúlio Vargas.

PAPY, Louis. À margem do império do café. A Fachada Atlântica de São Paulo. Boletim Geográfico, v. 15, n. 137, 1957, p. 139-166. (Transcrições.)

Paula, Eurípedes Simões de. Desdobramento do curso de Geografia e História na Faculdade de Filosofia, Ciências e Letras da Universidade de São Paulo. Revista de História, v. 12, n. 25,1956, p. $285-286$.

PAVAn, Crodowaldo. Faculdade de Filosofia da USP: lições inesquecíveis. Estudos Avançados, v. 7, n. 18, 1993, p. 189-207. Entrevista.

Penha, Eli A. A Criação do IBGE no Contexto de Centralização Política do Estado Novo. Rio de Janeiro: IBGE/CDDI, 1993. 128p.

Penteado, Antônio Rocha. Defesa de tese apresentada a cadeira de Geografia do Brasil da FFCL-USP, pelo licenciado José Ribeiro de Araújo Filho. Revista de História, v. 1, n. 4, 1950, p. 593-594.

PereIRA, Renato Rodrigues. Limites. Revista Brasileira de Geografia, v. 3, n. 1, 1941, p. 114-24. (Inquéritos Geográficos.)

PEREIRA, Renato Rodrigues. O Barão do Rio Branco e o traçado das fronteiras do Brasil. Revista Brasileira de Geografia, v. 7, n. 2, 1945, p. 187-244. 
PessoA, Heitor E. A. A cooperação disciplinada e os recentes progressos da estatística no Brasil. Revista Brasileira de Estatística, Rio de Janeiro: IBGE, v. 1, n. 1, 1940.

Petrone, Pasquale. Anotações sobre o Departamento de Geografia. Revista do Departamento de Geografia, v. 1, 1982, p. 7-19.

Prado Jr., Caio. A Cidade de São Paulo. Geografia e História. São Paulo: Brasiliense, 1983.

PrAdo Jr., Caio. História econômica do Brasil, 26.ed., São Paulo: Brasiliense, 1981.

REIS, Artur César Ferreira; OliveirA, Leônidas de As cabeceiras do Orenoco e a fronteira brasileiro-venezuelana. Revista Brasileira de Geografia, v. 6, n. 2, 1944, p. 245-257. (Comentários.)

Revista Brasileira de GeOgrafia. Rio de Janeiro: IBGE, v. 47, n. 1 e 2, 1985. 314 p.

RiBEIRO, Adalberto M. O Instituto Brasileiro de Geografia e Estatística. Revista Brasileira de Estatística, ano 5, n. 19, jul-set 1944, pp. 387-413.

RIBEIRO, Guilherme. Geografia, fronteira do mundo. Ensaio sobre política, epistemologia e história da geografia. GEOgraphia, ano 17, n. 34, 2015, p. 39-73.

RuEllan, Francis. As normas da elaboração e da redação de um trabalho geográfico. Revista Brasileira de Geografia, v. 5, n. 4, 1943b, p. 559-572.

RuELlAN, Francis. Evolução geomorfológica da Baía de Guanabara e das regiões vizinhas. Revista Brasileira de Geografia, v. 6, n. 4, 1944c, p. 445-508.

RUELLAN, Francis. O trabalho de campo nas pesquisas originais de geografia regional. Revista Brasileira de Geografia, v. 6, n. 1, 1944a, p. 35-50.

RuEllan, Francis. Orientação científica dos métodos de pesquisa geográfica. Revista Brasileira de Geografia, v. 5, n. 1, 1943a, p. 51-60.

RUELLAN, Francis. Um novo método de representação cartográfica do relevo e da estrutura aplicado à região do Rio de Janeiro. Revista Brasileira de Geografia, v. 6, n. 2, 1944b, p. 219234.

SALVI, Rosana Figueiredo. Tradições de pesquisa geográfica compreendidas pelo viés da Revista Brasileira de Geografia - 1939 a 1959. In: XI ENCONTRO NACIONAL DA ANPEGE, 2015, Presidente Prudente. Anais do XI ENANPEGE. Dourados: Ed. da UFGD, 2015, p. 9750-9761.

SAntos, Elina de Oliveira. A industrialização de Sorocaba: bases geográficas. São Paulo: Humanitas, 1999, 183p. (Série Teses) [Apresentado originalmente como tese de doutoramento à cadeira de Geografia Física da Faculdade de Filosofia, Ciências e Letras da Universidade de São Paulo, em 1951.

SANTOS, Milton. Por uma geografia nova: da crítica da geografia a uma geografia crítica. São Paulo: EDUSP, 2004. 
SCHWARTZMAn, Simon. A universidade primeira do Brasil: entre intelligentsia, padrão internacional e inclusão social. Estudos Avançados, v. 20, n. 56, 2006, p. 161-189.

Schwartzman, Simon. Universidades em São Paulo e na Federação. São Paulo em Perspectiva. São Paulo: Fundação SEADE, v. 2, n.4, p. 33-36, 1988.

SEABrA, Manoel Fernando Gonçalves. Os primeiros anos da Associação dos Geógrafos Brasileiros: 1934-1945. Terra Livre, ano 20, v. 1, n. 22, 2004, p. 13-68.

SENRA, Nelson de Castro. A junção do G ao E na formação do IBGE. Terra Brasilis Online (Nova Série), v. 3, 2014. Disponível em: <http://terrabrasilis.revues.org/926>. Acesso em: 26 nov. 2014.

SENRA, Nelson de Castro. História das estatísticas brasileiras. 3 volumes. Rio de Janeiro: IBGE-CDD, 2006. 2305 p. [Leitura fragmentada de diversos trechos, a partir da leitura de SENRA, 2009.]

SENRA, Nelson de Castro. Uma Breve história das estatísticas brasileiras (1822-2002). Rio de Janeiro: IBGE-CDD, 2009. 474 p.

Setzer, José. Goiânia. Levantamento agro-geológico do Estado de São Paulo. Revista Brasileira de Geografia, v. 3, n. 1, 1941, p. 82-107.

Silva, Moacir M. F. Fronteiras internacionais. Revista Brasileira de Geografia, v. 3, n. 3, 1941, p. 626-635. (Comentários.) [Resenha da obra homônima sob autoria de S. Whittemore BOGGS.]

Silva, Moacir M. F. Geografia das fronteiras no Brasil. Alguns aspectos. Revista Brasileira de Geografia, v. 4, n. 4, 1942, p. 749-70.

SiLva, Moacyr M. F. Fronteiras internacionais. Revista Brasileira de Geografia, v. 3, n. 3, 1941, p. 626-635. (Comentários.)

SiLVA, Moacyr. Geografia dos Transportes no Brasil. Revista Brasileira de Geografia, Rio de Janeiro: IBGE, v.1, n.2, p. 84-97; n.3, p. 60-72; n.4, p. 55-69, 1939; v.2, n.1, p. 35-52; n.2, p. 216-239; n.3, p. 407-439, n.4, 1940; v.3, n.1, p. 560-588; n.2, p.374-402; n.3, p. 589-607; n.4, p. $825-844,1941$.

SilveIRA, João Dias da. Estudo geográfico dos contrafortes ocidentais da Mantiqueira. São Paulo, 1946, 133p. Tese (Doutorado) - Faculdade de Filosofia, Ciências e Letras, Universidade de São Paulo.

Simas, Adriana De Melo. A Revista Brasileira de Geografia em foco: um panorama político-territorial do Brasil - 1939 a 1945. Rio de Janeiro, 2008, 91 p. Dissertação (Mestrado) - Instituto de Geografia, Universidade do Estado do Rio de Janeiro.

SkidMORE, Thomas. Brasil: de Getúlio a Castello. São Paulo: Cia. das Letras, 2010 [1967]. SoARES, José C. de Macedo Soares. Atividades do Instituto Brasileiro de Geografia e Estatística. Revista Brasileira de Geografia, v. 1, n. 1, 1939, p. 95-103. (Noticiário.) 
SODRÉ, Nelson Werneck. Introdução à Geografia. (Geografia e ideologia.) 8.ed., Petrópolis: Vozes, 1992.

SousA, Gabriel Soares de. Tratado descritivo do Brasil em 1587. [S.1.]: [s.n.], 1851. Disponível em: <http://www.dominiopublico.gov.br/download/texto/me003015.pdf $>$. Acesso em: 01 nov. 2014.

SousA, Henrique Cáper A. de. O ouro e a vida nalgumas regiões do Brasil. Revista Brasileira de Geografia, v. 2, n. 1, 1940, p. 16-34.

SouzA, Adauto de Oliveira. Conjuntura política brasileira, a Geografia e a AGB. Boletim Goiano de Geografia, Goiânia, v. 26, n. 2, jul-dez 2006, p. 71-86.

Strauch, Lourdes Manhães de Mattos. Contribuição ao estudo geográfico da erva-mate. Revista Brasileira de Geografia, v.17, n. 1, 1955, p. 94-106. (Comentários.)

TAunay, Affonso de E. Velhos censos. Revista Brasileira de Estatística, Rio de Janeiro: IBGE, v. 14, n. 53, p. 39-41, 1953.

VALVERDE, Orlando. Pré-história da AGB carioca. Terra Livre, ano 10, 1992, p. 117-122.

VArgas, Pres. Getúlio. Discurso em Guaíra. Cultura Política, ano 4, n. 39, abr. 1944, p. 11 15. (Transcrição.) Disponível em: <http://www.fgv.br/cpdoc/acervo/arquivopessoal/MS/impresso/cultura-politica-rev-mensal-de-estudos-brasileiros-33>. Acesso em: 29 jul. 2016.

Varnhagen, F. A. de. O Congresso Estatístico de S. Petersburgo em agosto de 1872. Revista Brasileira de Estatística, Rio de Janeiro: IBGE, v. 7, n. 26, 1946, p. 378-387.

Vervloet, Roberto José Hezer Moreira; Ross, Jurandyr Luciano Sanches. Revisão dos conhecimentos sobre o relevo do planalto atlântico brasileiro: incógnitas que ainda persistem. Revista do Departamento de Geografia, São Paulo: DG-FFLCH-USP, v. 23, p. 187-216, 2012. Disponível em: <http://www.revistas.usp.br/rdg/article/view/47210/50946>. Acesso em: 23 jan. 2015.

VIANA, Maj. João Segadas. Divisão territorial do Brasil. Revista Brasileira de Geografia, v. 2, n. 3, 1941, p. 372-406.

VITTE, Antônio Carlos. A construção da geomorfologia no Brasil. Revista Brasileira de Geomorfologia, v. 12, n. 3, p. 91-108, 2011. Disponível em: $<$ http://www.lsie.unb.br/rbg/index.php/rbg/article/view/262/198>. Acesso em: 11 jun. 2015.

VITTE, Antônio Carlos. A geografia física no Brasil: um panorama quantitativo a partir de periódicos nacionais (1928-2006). Revista da ANPEGE, n. 4, p. 29-45, 2008. Disponível em: $<$ http://anpege.org.br/revista/ojs-2.2.2/index.php/anpege08/article/view/10/pdf3B $>$. Acesso em: 11 jun. 2015.

VitTe, Antonio Carlos. Breves considerações sobre o papel de Pierre Monbeig na formação do pensamento geomorfológico uspiano. Confins Online, v. 11, 2011. 15p. Disponível em: $<$ http://confins.revues.org/6954>. Acesso em: 13 abr. 2016. 
WAIBEL, Leo Heinrich. A teoria de von Thünen sobre a Influência da distância do mercado relativamente a utilização da Terra. Sua aplicação a Costa Rica. Revista Brasileira de Geografia, v. 10, n. 1, 1948, p. 3-40.

WAIBEL, Leo Heinrich. Uma viagem de reconhecimento ao sul de Goiás. Revista Brasileira de Geografia, v. 9, n. 3, 1947, p. 313-43.

ZARUR, Jorge. Geografia: ciência moderna ao serviço do homem. Revista Brasileira de Geografia, v. 6, n. 3, 1944, p. 313-326.

ZARUR, Jorge. Geopolitics: the strugle for space and power. Revista Brasileira de Geografia, v. 4, n. 4, 1942, p. 849-52. [Resenha da obra homônima traduzida para o inglês sob autoria de Robert STRASZ-HUPÉ.]

ZIPPELIUS, Reinhold. Teoria geral do Estado, 1984. (Leitura parcial.) 


\section{ANEXOS}

ANEXO A - Termos (descritores e palavras-chave) empregados pela Biblioteca Central do IBGE para classificar os materiais publicados. Cf. REVISTA BRASILEIRA DE GEOGRAFIA. Rio de Janeiro: IBGE, v. 47, n. 1 e 2, 1985, p. 225-280.

Ábaco (gráfico), abastecimento, açude, aerofotografia, aerofotogrametria, agricultura, água mineral, agua subterrânea, alimentação, altimetria, antropologia, área territorial, arqueologia, arroz, Associação dos Geógrafos Brasileiros, assoreamento, astronomia, babaçu, bacia hidrográfica, bacia sedimentar, batata, bibliografia, biogeografia, biologia, borracha, botânica, caatinga, cacau, cadeia de Markov, café, cana-de-açúcar, carnaúba, carstificação, cartografia, cartógrafo, carvão, castanha, censo demográfico, cerâmica, classificação climática, classificação de Gaussen, classificação de Koeppen, classificação de Thornthwaite, climatologia, colonização, comércio, Comissão do Vale do São Francisco, Companhia Ford Industrial do Brasil, Comunidade Econômica Europeia, Conselho Nacional de Geografia, coordenadas geográficas, corredor de exportação, crescimento populacional, crescimento urbano, demografia, densidade demográfica, desenvolvimento regional, desenvolvimento rural, desequilíbrio regional, desertificação, desmatamento, diagrama, dialetologia, dicionário, difusão de inovações, distribuição espacial da população, divisão política, divisão regional, divisão territorial, ecologia, ecologia urbana, economia, economia agrícola, economia pesqueira, educação, energia, ensino da geografia, ensino de primeiro grau, ensino superior, erosão, Espírito Santo, estatística, estereofotogrametria, estratigrafia, estruturação do espaço, etimologia, etnografia, extrativismo vegetal, fauna, favela, fecundidade, ferrovia, filosofia da ciência, fitogeografia, floresta, folclore, fotogrametria, fotointerpretação, fronteira, fronteira agrícola, fumo, garimpo, geada, geodesia, geofísica, geografia, geografia agrária, geografia da população, geografia econômica, geografia física, geografia humana, geografia política, geografia quantitativa, geografia regional, geografia urbana, geógrafo, geologia, geometria, geomorfologia, geomorfologia fluvial, geomorfologia litorânea, geopolítica, habitação, hidrografia, hidrologia, hidrometria, hierarquia urbana, história social, iluminação pública, índice de Oliver, indigenismo, indústria, indústria de transformação, industrialização, inundação, investimento público, irrigação, laterização, Percy Alfred Lau, lazer, legislação, litoral, localização industrial, manguezal, mapa, mapa municipal, mapeamento, mapeamento geológico, mapeamento geomorfológico, mate, mercado consumidor, meteorologia, metodologia da pesquisa, migração, milho, mineração, modelo de von Thünen, normalização, nutrição, oceanografia, olaria, ouro, paleoclimatologia, paleogeografia, palinologia, palmito, parque nacional, pecoaria, pedologia, pesca, petróleo, petrologia, planejamento econômico, planejamento municipal, planejamento regional, planejamento urbano, pluviometria, política, polo de desenvolvimento, população de baixa renda, população economicamente ativa, pororoca, porto, produção agrícola, projeto Radar, propriedade rural, recursos energéticos, recursos florestais, recursos hídricos, recursos minerais, recursos naturais, reforma agrária, região homogênea, região metropolitana, região natural, regionalização, relevo, renda (economia), Revista Brasileira de Geografia, rodovia, salina, sambaqui, saúde, Waldemar Schultz, seca, sedimentologia, segurança nacional, sensoriamento remoto, setor informal, setor terciário, sisal, sociologia, solo, tanino, tectônica, topografia, toponímia, trabalhador rural, trabalho, tráfego, transporte, trigo, turismo, urbanismo, urbanização, uso do solo, uva, vocabulário, voçoroca, zona rural, zoogeografia, zoologia. 
ANEXO B - Linha do tempo com os principais eventos e instituições acadêmicas e burocráticas diretamente relacionadas à institucionalização da ciência geográfica no Brasil.

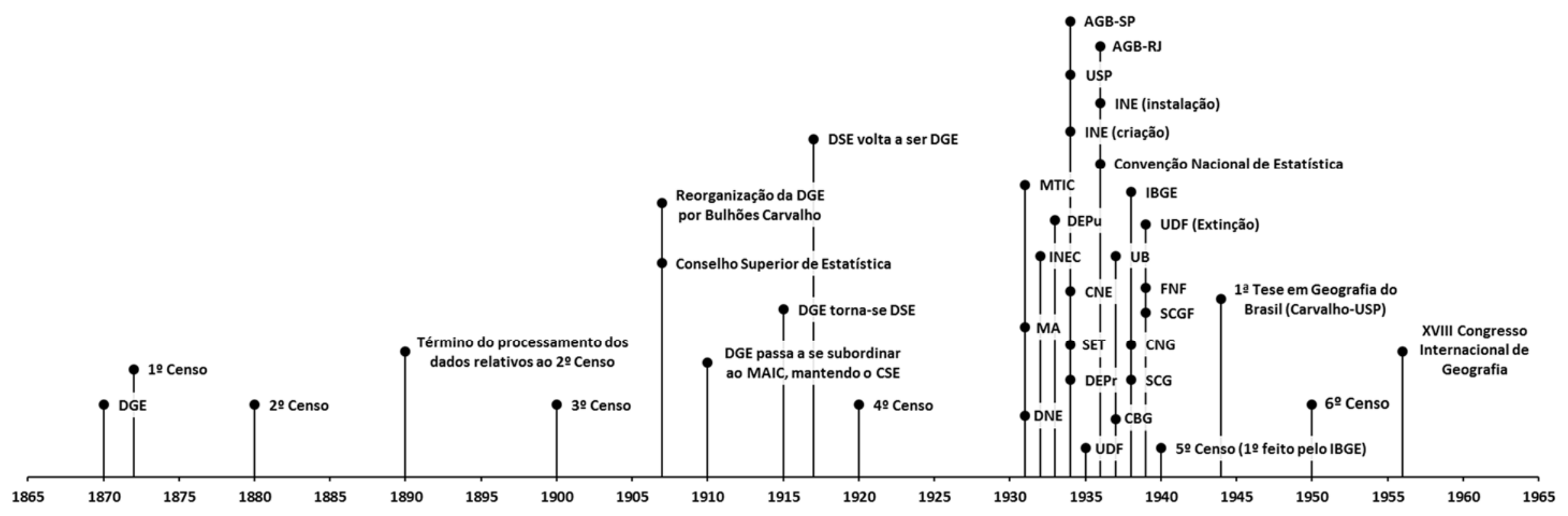

AGB Associação dos Geógrafos Brasileiros

CBG Conselho Brasileiro de Geografia

CNE Conselho Nacional de Estatística

CNG Conselho Nacional de Geografia

CSE Conselho Superior de Estatística

DEC Diretoria de Estatística Comercial

DEPr Diretoria de Estatística da Produção

DEPu Diretoria de Estatística e Publicidade

DGE Diretoria Geral de Estatística

DNE Departamento Nacional de Estatística

DSE Diretoria do Serviço de Estatística
FNF Faculdade Nacional de Filosofia

IBGE Instituto Brasileiro de Geografia e Estatística

INE Instituto Nacional de Estatística

MA Ministério da Agricultura

MAIC Ministério da Agricultura, Indústria e Comércio

SCG Serviço de Coordenação Geográfica

SCGF Serviço de Geografia e Estatística Fisiográfica

SET Secretaria de Estatística Territorial

SGRJ Sociedade de Geografia do Rio de Janeiro

UDF Faculdade do Distrito Federal

USP Universidade de São Paulo
Algumas diretorias de menor impacto no desenvolvimento institucional do IBGE foram omitidas na linha do tempo, tais como a Diretoria de Estatística Geral, subordinada ao Ministério da Justiça e Negócios Interiores, a Diretoria de Estatística Econômica e Financeira, do Ministério da Fazenda, a Diretoria de Estatística da Produção, da Secretaria de Estado da Agricultura, e a Diretoria de Informações, Estatística e Divulgação, da Secretaria de Estado da Educação, todas repartições centrais que seriam parte constitutiva do INE. (Cf. GONÇALVES, 1995, p. 28) 


\begin{tabular}{|c|c|c|c|c|c|c|}
\hline AUTOR & Título & ANO & Ref: v.(n.):pp. & LUGAR & SEÇÃO & SUBÁREA \\
\hline OLIVEIRA, Américo Barbosa de. & Considerações sobre a exploração da castanha no baixo e médio Tocantins. & 1940 & $02(1): 3-15$. & TO & A & GE \\
\hline CARLI, Gileno Dé. & Civilização do açúcar no Brasil. & 1940 & $02(3): 349-71$ & BR & A & GA \\
\hline CARLI, Gileno Dé. & Evolução do problema canavieiro fluminense. & 1943 & $05(2): 255-66$ & RJ & $\mathrm{R}$ & GA \\
\hline MElo, Beatriz Célia Correia de. & Interpretação do mapa de produção de café no sudeste do Planalto central do Brasil. & 1950 & 12(1):73-88. & $\mathrm{CO}$ & A & GE \\
\hline SIMÕES, Ruth Matos Almeida. & Distribuição da produção do arroz no sudoeste do Planalto Central. & 1950 & $12(2): 269-84$ & $\mathrm{CO}$ & A & GA \\
\hline SIMÕES, Ruth Matos Almeida. & Interpretação do mapa de produção de cana de açúcar no sudeste do Planalto Central. & 1950 & $12(3): 371-82$ & $\mathrm{CO}$ & A & GA \\
\hline BERNARDES, Lísia M. C.; BERNARDES, Nilo. & A pesca no litoral do Rio de Janeiro. & 1950 & $12(1): 17-53$. & RJ & A & GA \\
\hline CARvalho, Eloísa de. & O trigo no Brasil. & 1951 & 13(4):591-608. & BR & A & GE \\
\hline CARVAlHo, Eloísa de. & A produção de batata inglesa no Sul do País. & 1952 & $14(3): 354-62$ & SUL & $\mathrm{C}$ & GA \\
\hline STRAUCH, Ney. & Contribuição ao estudo das feiras de gado; Feira de Santana e Arcoverde. & 1952 & 14(1):101-10. & $\mathrm{NE}$ & $\mathrm{C}$ & GA \\
\hline MESQUISA, Myriam Gomes Coelho. & Distribuição do gado bovino no sudeste do Planalto Central. & 1952 & 14(1):113-9. & $\mathrm{CO}$ & $\mathrm{C}$ & GE \\
\hline GUERRA, Inês Amélia Teixeira. & O cacau na Bahia. & 1952 & 14(1):81-100. & BA & A & GE \\
\hline MAYOR, Ariadne Soares Souto. & O sal no Rio Grande do Norte. & 1952 & 14(3):339-53. & $\mathrm{RN}$ & $\mathrm{C}$ & GE \\
\hline VELOSO, Marília Gosling. & A explotação da borracha na região dos formadores dos rios Arinos e Teles Pires; norte de Mato Grosso. & 1952 & 14(4):377-406. & MT & A & GE \\
\hline SIMÕES, Ruth Matos Almeida. & Produção de uva no Rio Grande do Sul. & 1952 & $14(4): 472-85$ & RS & $\mathrm{C}$ & GE \\
\hline Pettei, Beatris Célia Corrêa de Mello. & Produção de milho e suínos no Brasil meridional. & 1954 & 16(3):329-66. & SUL & A & GE \\
\hline BERNARDES, Lísia Maria Cavalcante. & Cultura e produção do arroz no Sul do Brasil. & 1954 & $16(4): 403-38$ & SUL & A & GA \\
\hline MELo, Mário Lacerda de. & Aspectos da geografia do açúcar no Brasil. & 1954 & $16(4): 467-92$ & BR & A & GA \\
\hline Botelho, Carlos de Castro. & Aspectos geográficos da zona cacaueira da Bahia. & 1954 & $16(2): 161-212$ & $\mathrm{BA}$ & A & GA \\
\hline CAMPOS, Maria da Glória de Carvalho. & Notas para um estudo da distribuição do rebanho bovino no Brasil meridional. & 1955 & 17(3):331-42. & SUL & $\mathrm{C}$ & GE \\
\hline STRAUCH, Lourdes Manhães de Mattos. & Contribuição ao estudo geográfico da erva-mate. & 1955 & 17(1):94-106. & SUL & $\mathrm{C}$ & GA \\
\hline GALVÃO, Roberto. & Aspectos da economia da borracha no Território do Acre. & 1955 & $17(2): 153-73$ & $\mathrm{AC}$ & A & GE \\
\hline HUECK, Kurt. & Bosques chaquenhos e extração de tanino no Brasil. & 1955 & $17(3): 343-6$. & MS & $\mathrm{C}$ & GE \\
\hline PINTO, Maria Magdalena Vieira. & Contribuição ao estudo da pesca na região do rio Arari; Ilha de Marajó. & 1956 & $18(3): 373-407$ & $\mathrm{PA}$ & A & GE \\
\hline VALVERDE, Orlando. & Geografia econômica e social do babaçu no meio Norte. & 1957 & 19(4):381-420. & MA & A & GE \\
\hline GUERRA, Antônio Teixeira. & Notas sobre o palmito em Iguape e Cananeia. & 1957 & $19(3): 345-55$ & $\mathrm{SP}$ & $\mathrm{C}$ & GE \\
\hline Alonso, Delnida Martinez. & Aspectos geográficos da cultura fumageira no Estado do Rio Grande do Sul, Brasil. & 1958 & 20(3):295-313. & RS & A & GA \\
\hline DiAs, Catarina V. & Aspectos geográficos do comércio da castanha no médio Tocantins. & 1959 & 21(4):517-31. & TO & A & GE \\
\hline LAGO, Paulo Fernandes de Araújo. & Contribuição geográfica ao estudo da pesca no litoral de Santa Catarina. & 1961 & $23(1): 121-215$. & $\mathrm{SC}$ & A & GE \\
\hline CASCUDO, Luís da Câmara. & A carnaúba. & 1964 & $26(2): 159-215$ & & A & BIOG \\
\hline VALVERDE, Orlando. & Reconhecimento na bacia leiteira do Rio de Janeiro. & 1964 & $26(4): 609-15$ & RJ & $\mathrm{C}$ & GE \\
\hline SANTOS, Ruth Simões Bezerra dos. & Fitoclimograma esquemático da videira no Brasil. & 1966 & $28(2): 113-27$ & BR & A & GE \\
\hline PINTO, Maria Novais. & Contribuição ao estudo da influência da lavoura especulativa do sisal no Estado da Bahia. & 1969 & 31(3):3-102. & BA & A & GA \\
\hline
\end{tabular}

Legenda: A - Artigo; C - Comentários; R - Resenha; GA - Geografia Agrícola; GE - Geografia Econômica; BIOG - Biogeografia; $\checkmark$ - material fichado. 


\begin{tabular}{|c|c|c|c|c|c|}
\hline $\begin{array}{l}\text { CARVALHO, Maria Conceição Vicente de. } \\
\text { Santos e a geografaia humana do ditoral } \\
\text { paulista. São Paulo, 1944, 219p. Tese } \\
\text { (Doutorado) - FFCL-USP. }\end{array}$ & $\begin{array}{l}\text { SILvEIRA, João Dias da. Estudo } \\
\text { geografico dos contrafortes ocidentais } \\
\text { da Mantiqueira. Să Paulo, 1946, 133p. } \\
\text { Teses (Doutrorado) - FFCL-USP. }\end{array}$ & $\begin{array}{l}\text { MüLLER, Nice Lecocq. Sítios e sitiantes no Estado de São Paulo. } \\
\text { São Paulo: FFCL-USP, 1951 [1946], 217p. (Boletim 132) }\end{array}$ & $\begin{array}{l}\text { MENDES, Renato da Silveira. Paisagens culturais da Baixada Fluminense. São Paulo: } \\
\text { FFCL-USP, } 1950 \text { [1948], 171p. (Boletim 110) }\end{array}$ & 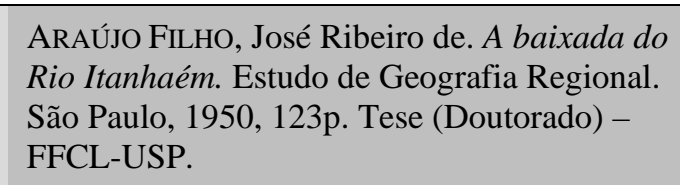 & $\begin{array}{l}\text { SANTOS, Elina de Oliveira. A industrialização de } \\
\text { Sorocaba bases geograficas. Sãa Paulo: Humanitas, } \\
\text { 1999 [1951], 183p. (Série Teses) }\end{array}$ \\
\hline 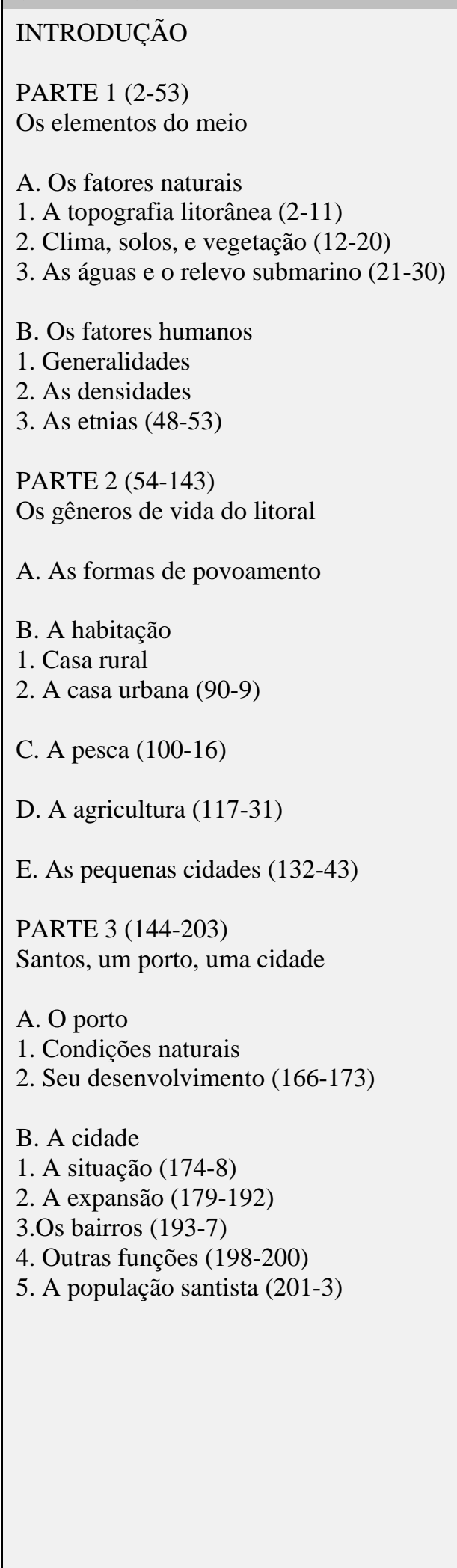 & 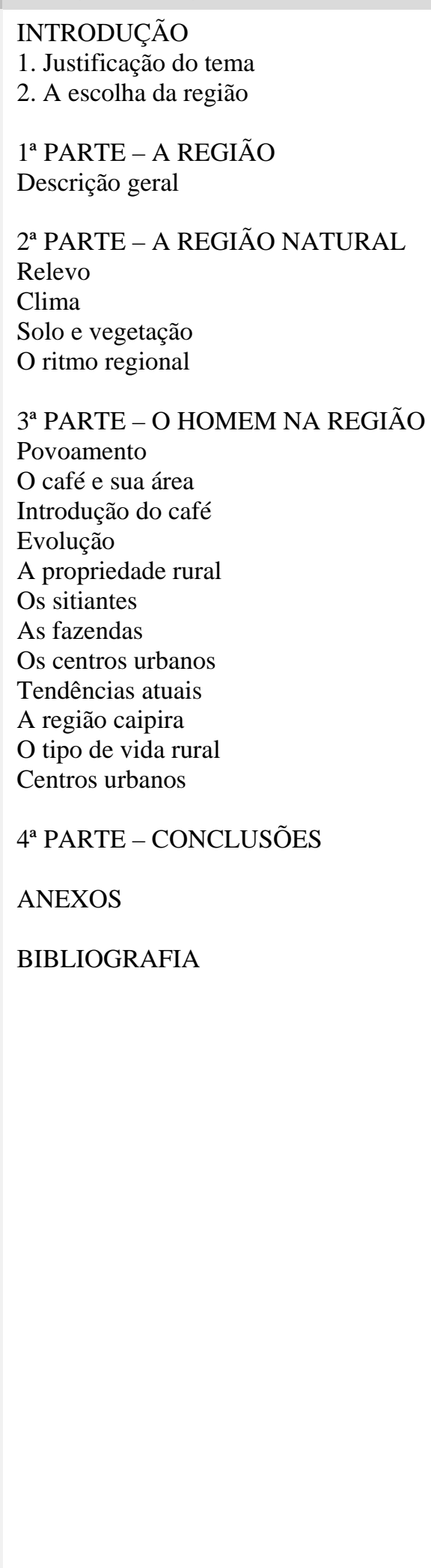 & 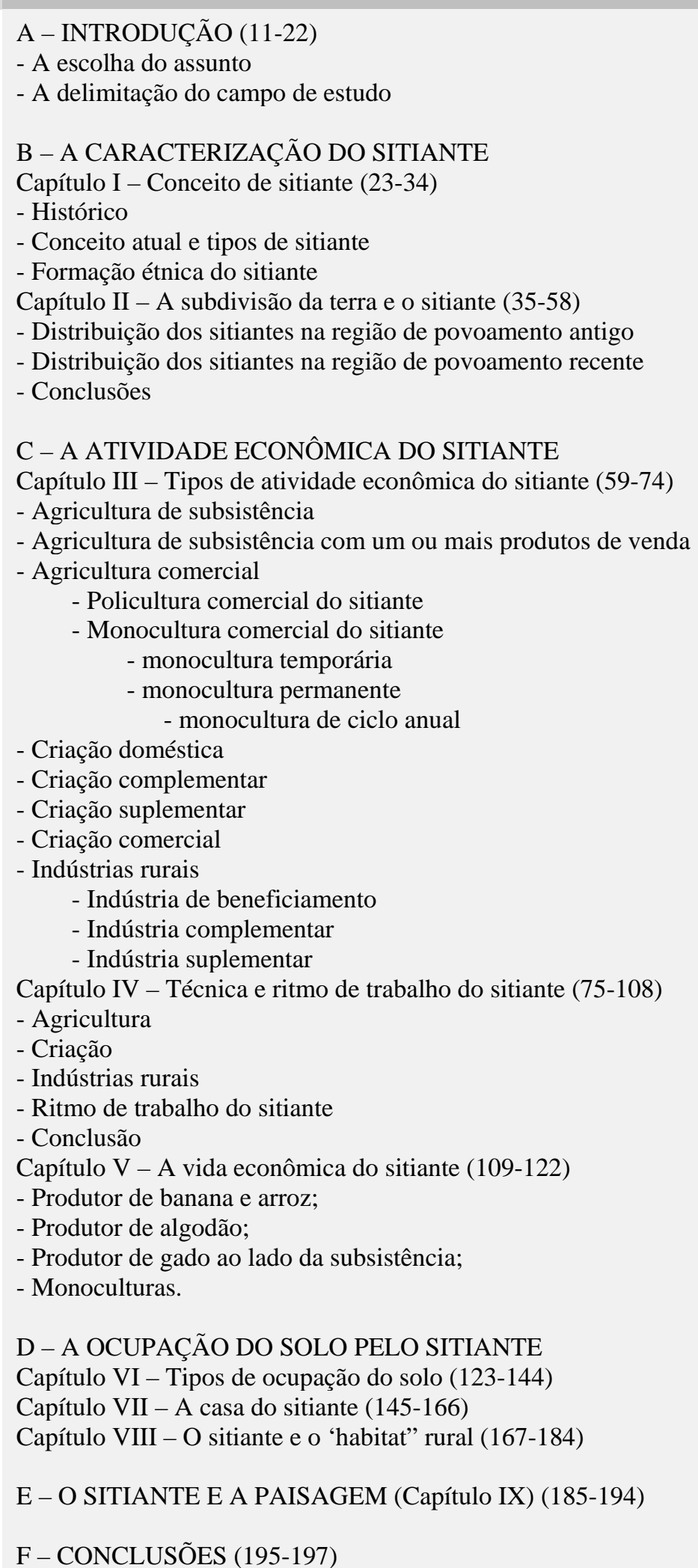 & 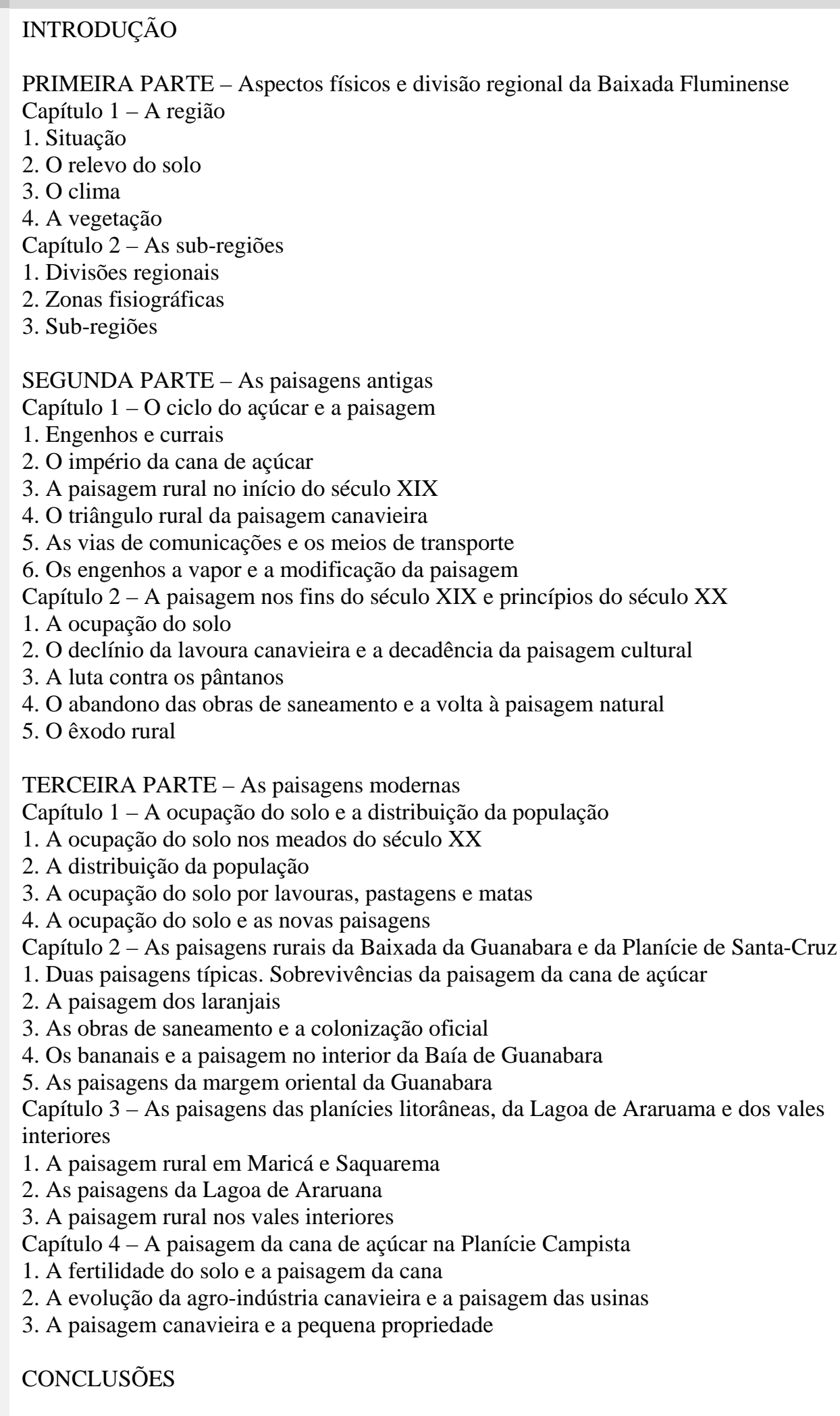 & 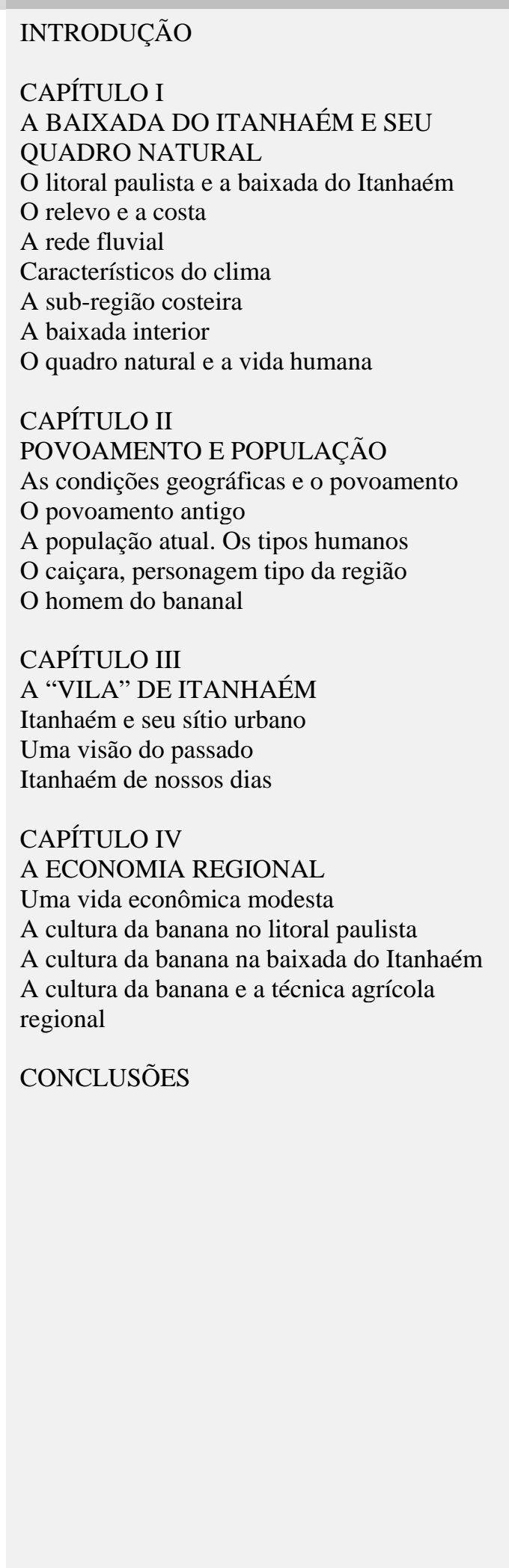 & 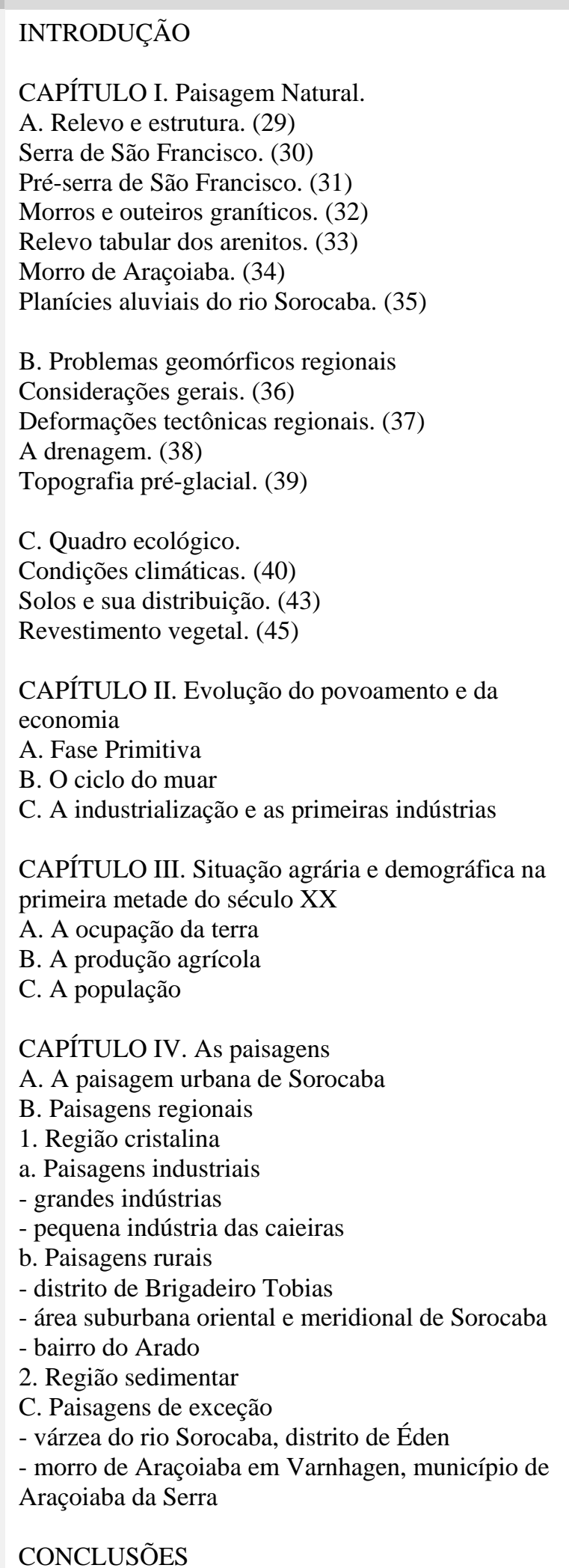 \\
\hline
\end{tabular}

